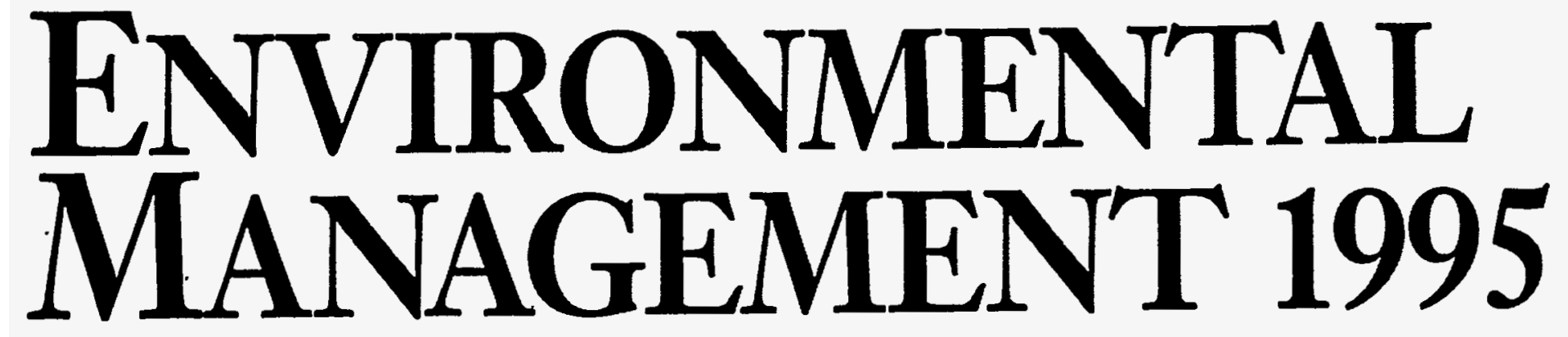

\title{
Progress and Plans of the Environmental Management Program
}

บดย/EM-0228
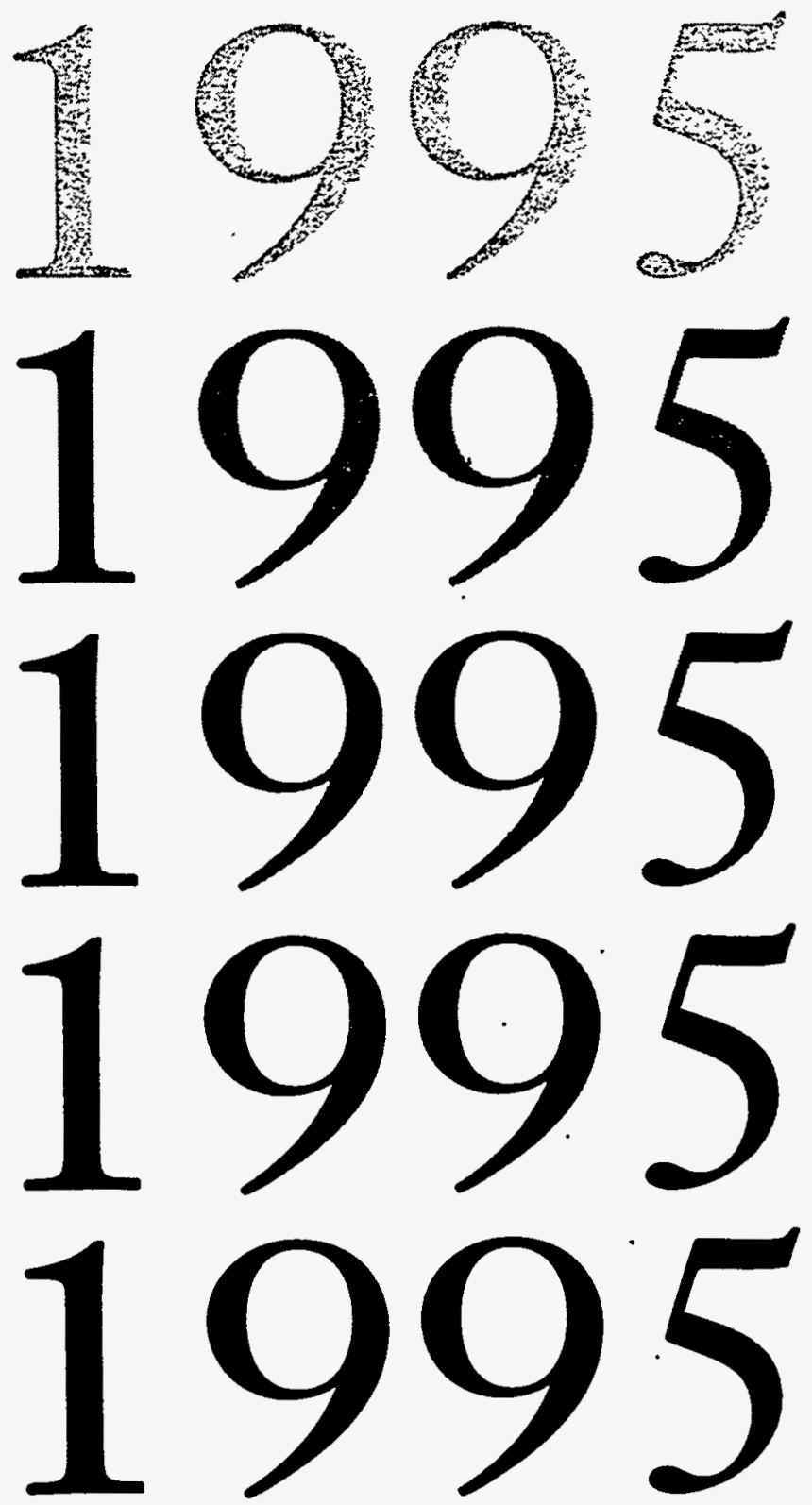


\section{DISCLAIMER}

This report was prepared as an account of work sponsored by an agency of the United States Government. Neither the United States Government nor any agency thereof, nor any of their employees, make any warranty, express or implied, or assumes any legal liability or responsibility for the accuracy, completeness, or usefulness of any information, apparatus, product, or process disclosed, or represents that its use would not infringe privately owned rights. Reference herein to any specific commercial product, process, or service by trade name, trademark, manufacturer, or otherwise does not necessarily constitute or imply its endorsement, recommendation, or favoring by the United States Government or any agency thereof. The views and opinions of authors expressed herein do not necessarily state or reflect those of the United States Government or any agency thereof. 


\section{DISCLAIMER}

Portions of this document may be illegible in electronic image products. Images are produced from the best available original document. 

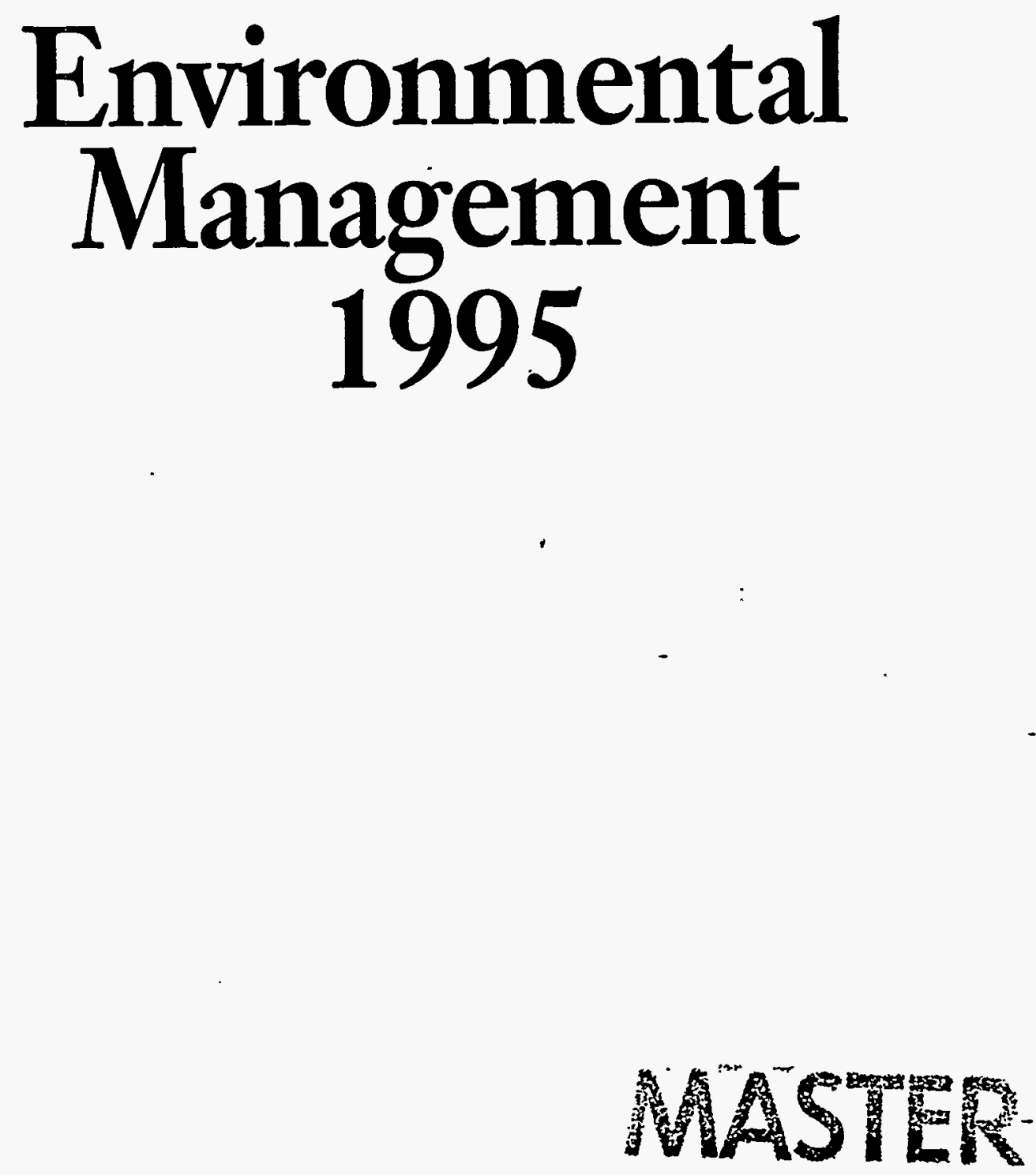

DISTRIBOTION Of THIS DOCUMENT is UNLIAITE

Q Printed with soy ink on recycled paper 


\section{Readers' Guide to Environmental Management 1995:}

Environmental Management 1995 is the second report prepared in response to the requirements of the National Defense Authorization Act for Fiscal Year1994. The first report, Environmental Management 1994, was published in February 1994. This report is intended to provide a broad overview of the Environmental Management program's activities in 1994, 1995, and 1996.

The first section of this report describes the Department of Energy's Environmental Management program. This is followed by a closer look at what the program is doing across the country, organized by region to help the reader identify and locate sires of interest. Within each region, details of the largest sites are followed by site summaries reported by State and a summary of activities under the Formerly Utilized Sites Remedial Action Program (FUSRAP) and Uranium Mill Tailings Remedial Action Project (UMTRA).

The sites at which Environmental Management is active are sometimes referred to collectively as the "weapons complex." The complex includes all sites that performed nuclear energy or weapons research, development, testing, or production for the Department of Energy or its predecessor agencies. All sites where the Department of Energy actively conducted environmental management activities in 1994 are described in this report. Sites for which Environmental Management has management responsibilities, such as sites at which work was completed prior to 1994 or sites recently transferred to the program where work has not yet begun, are nor discussed in this report.

For the purposes of this report, a "site" is a Department of Energy installation; a "facility" is a building located on a Department of Energy site; and an "area" is a geographical area, operable unit, or waste area group of unspecified dimension within a site. Throughout this report, "year" refers to the Federal Government's Fiscal Year, which begins on October 1. For example, Fiscal Year 1995 began on October 1, 1994 and will end on September 30, 1995.

Budget totals for Hanford include the Hanford Site and Richland Operations Office. The Idaho National Engineering Laboratory includes the Idaho Chemical Processing Plant and the Idaho Operations Office. The Oak Ridge Reservation budget includes Oak Ridge National Laboratory, the Y-12 Plant, the K25 Site, Oak Ridge Associated Laboratories, the Oak Ridge Operations Office, and funding for the FUSRAP program.

For more information about the Environmental Management program, or specific information about the sites, programs, or activities described in this report, please contact the Center for Environmental Management Information at 1-800-7-EM-DATA (1-800-736-3282), or P.O. Box 23769, Washington, D.C. $20026-3769$. 


\section{Letter From the Secretary}

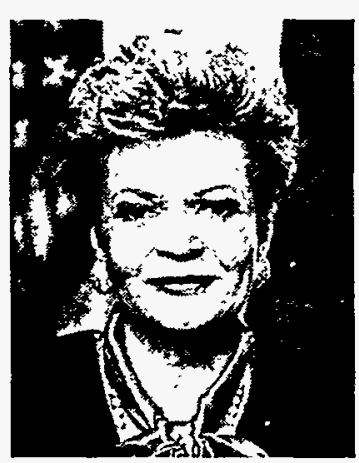

The Department of Energy provides critical products and services to the Nation in the areas of national security, environmental management, technology development, and energy resources. We are demonstrating the same national commitment that built the weapons which helped win the Cold War to addressing the resulting environmental and safety problems at our sites across the country. We also continue to improve the way we meet our obligations by emphasizing efficiency and results. In support of President Clinton's goal to make Government more effective, we are eliminating excess layers of management and the low priority tasks that burden our resources. We are aligning our human and capital assets with the Strategic Plan we developed in 1994.

On February 6, I pledged to deliver $\$ 14.1$ billion to the American taxpayer. This will mean a 17 percent reduction of our budget over the next 5 years and includes a $\$ 4.4$ billion reduction in Environmental Management program costs. Aehieving these savings will be a challenge and requires an examination of all the Department's functions, policies, and procedures. Fewer resources does not mean a diminished commitment to protecting public safety and health or the environment. It does mean even more attention to ensuring that we address the most urgent risks first. These budget challenges, and many complex environmental challenges, are already being met by the Department's Environmental Management program under the leadership of Thomas Grumbly.

I am pleased to present Environmental Management 1995, the second yearly report on the program's progress and plans. In 1994, Environmental Management improved its efficiency, reduced costs, and most importantly, achieved real results: sites remediated, large amounts.of waste safely contained, and exciting new cleanup technologies developed. I look forward to reporting on our progress during 1995 in next year's report.

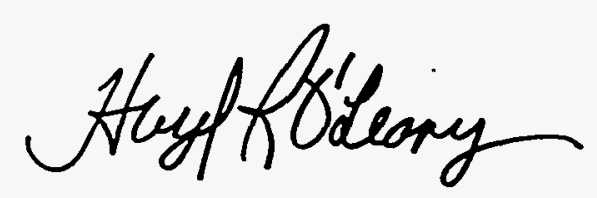

Hazel R. O'Lear'

Secretary of Energy 


\section{Letter From the Assistant Secretary}

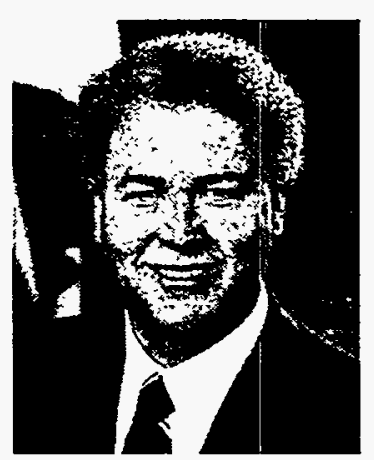

In 1994, we worked hard to improve the Environmental Management program in order to maintain, and build upon, our credibility with Congress and our stakeholders. Exaniples of our accomplishments are illustrated on the following pagc. This report, Environmental Management 1995, is the second yearly report on the progran's progress and plans. Throughout the report, you will find assessments of the program's performance in 1994 and comparisons against our performance in 1993.

Over the last 15 months, the Environmental Management program initiated scveral new procedures to ensure that all operations within the program are geared to meet the program goals and to show a direct relationship between resources expended and results. As a result, we have increased the amount of remediations to be completed compared to studies and surpassed the 1994 goal for remediation and number of interim actions completed. Urgent risks to the environment and the public, such as those risks associated with spent nuclear fuel and the high-level radioactive wastc tank 101-SY at Hanford, were reduced. Technology development resources have been focused on finding solutions to the five most pressing issues facing the Department. More than 20 technologies for treating volatile organic compounds and arid soils were demonstrated in 1994 through partnerships with private industry, and 24 technologies were transferred or made available to private industry. We are also recompeting contracts worth more than $\$ 28$ billion to attract the best qualified environmental contractors, implement fee provisions that reward improved performance, promote cost savings, and provide increased accountability for contractors. We also served as a pilor project under the Government Peformance and Results Act, which holds Federal agencies accountable for achicving program results.

On the strength of this kind of progress, we intend to achieve $\$ 300$ million in productivity savings for 1995. Coupled with reductions in project management costs, contractor personnel, overhead and indirect costs, and cfficiency improvements at each site, the Environmental Management program will realize over $\$ 2.1$ billion in permanent budget savings. However, we will need to keep tightening the belt in 1996 and 1997. Our remediation tasks urill grow in the years ahead, as will our responsibilities to safely and wisely manage fissile materials, stabilize them in the short term, and decide their ultimate disposition in the long term while our budget declines. Our best estimate is that by the year 2000, without productivity improvements, we will need more than $\$ 10$ billion to meet our obligations. If we achieve the productivity savings that I think we can achieve, we will need about $\$ 8$ billion. Hounever, our most recent budget projection for 2000 is $\$ 5.5$ billion. This gap between our resources and responsibilities will begin to appear in 1996. In the months ahead we will work closely with Congress, the States, the regulators and our stakeholders to determine collectively how best to fulfill our responsibilities with the resources available to us.

We have some extremely complex policy and technical issues to debate, and some tough decisions to make. We are serious about getting the right infrastructure in place so that we have a program that can run at maximum efficiency, routinely spending every tax dollar as wisely as possible. I am confident that we can continue to make progress and that our program will ultimately be second to none in serving our Nation capably and efficiently.

If you have any comments or suggestions about this report or the information contained herein please contact the Center for Environmental Management Information at 1-800-7-EM-DATA, or 1-800-736-3282.

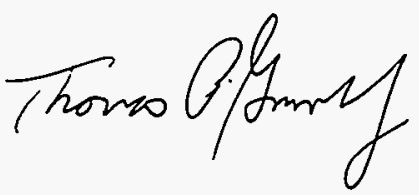

Thomas P. Grumbly

Assistant Secretary for Envirommental Management 


\section{Examples of Environmental Management Accomplishments in 1994}

\section{Goal 1: Eliminate and Manage Urgent Risks.}

- The high-level radioactive waste tank 101-SY at Hanford has had no significant gas release event since the installation of the test mixing pump. This pump's operation has minimized the retention of flammable gas and precluded the need for a permanent pump.

- At the Idaho National Engineering Laboratory 199 spent fuel rods were safely transferred to a more modem storage area.

\section{Goal 2: Emphasize Health and Safety of Our Workers and the Public.}

- Nearly half of the 52 Secretarial Safety Initiatives at Hanford were successfully completed in 1994, as scheduled.

- The rate of injuries and illnesses at the Y-12 Plant in Oak Ridge, Tennessee, was reduced by half between January 1993 and August 1994.

\section{Coal 3: Establish a System that is Managerially and Financially in Control.}

- The Chemical Exchange Warehouse at Lawrence Livermore National Laboratory has offset more than twice its startup costs by selling surplus, but usable, chemicals to other users rather than disposing of them as hazardous waste.

- Idaho National Engineering Laboratory consolidated its five contractors into one single contract, with a projected cost savings of over $\$ 500$ million in the next five years.

\section{Coal 4: Demonstrate Tangible Results.}

- Material and facility stabilization work at 2 facilities on the Hanford site was completed ahead of schedule with 10 percent more cost savings than anticipated.

- Remedial actions were completed at two Formerly Utilized Sites Remediation Action Program (FUSRAP) sites in Pennsylvania, one site in Illinois, and eight vicinity properties in New Jersey.

\section{Goal 5: Focus Technology Development Efforts To Identify and Overcome Obstacles to Progress.}

- The Technology Development program demonstrated nearly 60 new or improved technologies and made 24 new or improved technologies available for transfer to private industry in 1994.

- A license agreement for the Rapid Geophysical Surveyor, a hand-pushed vehicle that can perform geophysical magnetic surveys 30 to 300 times faster and 20 times less expensively than existing instruments, became available in 1994.

\section{Goal 6: Establish a Stronger Partnership Between the Department of Energy and Its Stakeholders.}

- The Department renegotiated the Hanford Tri-Party Agreement in a new manner by aggressively soliciting and incorporating input from local and regional stakeholders.

- With extensive involvement of state regulators, Draft Site Treatment Plans were completed for 48 sites in 22 States, and a process for continued negotiation with the States was established. 


\section{Environmental Management Across the Nation}

\begin{tabular}{|c|c|c|c|}
\hline * & Location & Installation/Site & $\begin{array}{l}\text { Page !! } \\
\text { Number }\end{array}$ \\
\hline 3 & - Fichland, WA & Hanloed SRe & 15 \\
\hline 2 & Atbany, 0ล & $\begin{array}{l}\text { Atbany Metallutgical Ressarth } \\
\text { Centes }\end{array}$ & 24 \\
\hline $3=$ & Lantery OR & 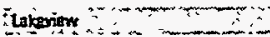 & 25 \\
\hline 4 & Davis, CA & $\begin{array}{l}\text { Laboratory for Energy-Related } \\
\text { Heath Research at U.C. Danss }\end{array}$ & 20 \\
\hline 5 & Bexterga." & Unverence Eertatey Liberatong & $2 i \div ;$ \\
\hline 6 & Berkeley, CA & Unversty of Caldforna & 24 \\
\hline$i^{\prime \prime}$ & "PaloAAR,CA" & Sunfort linat Aecalerentor & 23 \\
\hline 8 & Lvermore. CA & $\begin{array}{l}\text { Lawrence Lvermore Nationsal } \\
\text { Loboratory }\end{array}$ & 21 \\
\hline 9 & Livermors, CA & $\begin{array}{l}\text { Sondio kational laboratory } \\
\text { ivarnone. }\end{array}$ & 23 \\
\hline 10 & Vateectos CA & $\begin{array}{l}\text { Generat Bectre Va Hecitos Nucl } \\
\text { Center }\end{array}$ & 20 \\
\hline $11:$ & Gonerd & oxñan & $2 x$ \\
\hline & Sants Susana, CA & Sant Susana Field Loboratory & 23 \\
\hline$\because$ & Sarta Sustrica & 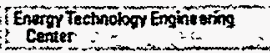 & $\ddot{2}$ \\
\hline 12 & Conoga Park (LA), CA & $\begin{array}{l}\text { Roctwrell Imernational (atornics } \\
\text { International| }\end{array}$ & 23 \\
\hline ב3 & Son biego, CA & Gineralatonice & $20 \div$ \\
\hline 14 & Impenal county. CA & Salton Sea Test Base & 23 \\
\hline $15^{-1}$ & Cape thomson, $A K$ & Froiectcharios & 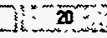 \\
\hline 16 & Anchinta Istond. AK & Amchata island Test Sne & 20 \\
\hline$\pi^{*}$ & Fillon: No & Projectshosisos. & 33 \\
\hline 18 & Tonopat, NV & Central Nevada Test Ares & 33 \\
\hline$\therefore$ & NBHSARB, HW & Topopan Testrange. ? ? & 3 \\
\hline & Metcury. in & Nevada Test Site & 29 \\
\hline $\mathrm{is}^{*}$ & Lowention & Lowman & 25 \\
\hline 20 & Idaho Falls 10 & $\begin{array}{l}\text { Id aho National Enginearns } \\
\text { Liboratory }\end{array}$ & 18 \\
\hline$\pi$ & déboralsio: & Aporpe Fisons ilsbortory & 24 \\
\hline 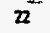 & Satt Lake City, UT & Satt Lake Ciry & 38 \\
\hline $3:$ & Green fiver un & Greanfliver & 40 \\
\hline $2 i$ & Mexiean HaL UT & - Mexiesn Hat & 40 \\
\hline $2=$ & Monticella, UT - & 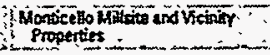 & $\pi$ \\
\hline 25 & Tuba Crot AZ & Tuba City & 38 \\
\hline 25 & Morument City $A \bar{Z}$ & 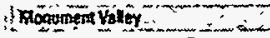 & 38 \\
\hline 21 & Bute, ist & $\begin{array}{l}\text { Western Emrongental Teeh } \\
\text { Office (WETO) }\end{array}$ & 24 \\
\hline 3 & Fiveron Wy & Folivantan. & 2 \\
\hline 29 & Spook w w & Spook & 26 \\
\hline 307 & Hender $\overline{c 0}:=$ & Aiflybetion & 39 \\
\hline 31 & Grand Valley co & Propet Rutison Ste & 32 \\
\hline & $\mathrm{BRH}_{\mathrm{a}} \mathrm{CO}^{\cdots}$ & ioid kifie & 3 \\
\hline & Parfe.có & New Rifle & 39 \\
\hline-1 & Bife $\mathrm{Cg}^{2+2}$ & Propetfito gsoses = & $32:$ \\
\hline 32 & Grand Junctor, Co & Geand Juncton Vicinty Psoperses & 33 \\
\hline & Grand Junction, $\mathrm{CO}^{\mathrm{m}}$ & Chon Bas Ste & 33 \\
\hline 3 & Naturta, $\mathrm{CO}$ & Naturta & 39 \\
\hline 34 . & Stek Fiock co: & Union Cantide & 40 \\
\hline & Slick Rock, co & old North Contenem & 40 \\
\hline$\underline{s}$ & Duranga, con-: & Durango & 39 \\
\hline 36 & Gunasan $\mathrm{CO}^{-}$ & Gunnson & 39 \\
\hline$\underline{j i}$ & Jefersion Cointy, co & Rochylatsplort - & 27 \\
\hline 33 & Formangton, NM & Projeet Gasbuggy Sace & 34 \\
\hline $30^{\prime}$ & Shiprock, Hus : & Shiproce & 40 \\
\hline$\infty$ & Ambrossa Leke, NM & Ambrosia Lake & 39 \\
\hline $4 i$ & Los Ahinos; HA & Los Áramos Nintonal L borstor & $33: 5$ \\
\hline $42^{-4}$ & Los Atamos. NM & Bavo Campon & 38 \\
\hline$=m$ & Los Aamos $\mathrm{NH}^{-}$ & ACAPueblo C2ayen & 38 \\
\hline 43 & Albuquetque. $\mathrm{MM}$ & South Vatter Stre & 34 \\
\hline & 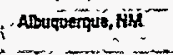 & 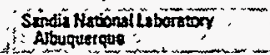 & s: \\
\hline & Albuquerque. NA & $\begin{array}{l}\text { Inhalaton Toxicology Research } \\
\text { Instutute }\end{array}$ & 36 \\
\hline 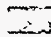 & Alboqbande, & I Holounas Atrores bass & 35, \\
\hline & Los Lunas, NM & Pagano Salvage Yard & 36 \\
\hline $4:$ & Whito Sands, NH & CivipuderäMesa & 38 \\
\hline 45 & Cartsbad, NM & Proptet Gnome-Cosch Site & 34 \\
\hline & Cartsodid NM & Wasta lisofation Plas Plant & 34 \\
\hline 46 & Bowman ND & Bowman & 25 \\
\hline 47 & Betsalision. & Bet5etr & $25=$ \\
\hline 48 & Edgemont SO & Edgemont Visurty Properties & 25 \\
\hline 4 & Linsoln, $M E$. & 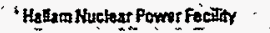 & 果? \\
\hline so & Amtanilo, IX & Pantex Plant & 35 \\
\hline 51. & Folls Ciry. TX: & Fals ciny & 40 \\
\hline 52 & Хauas, & Kaues Test Facitity & 24 \\
\hline 5 & Anes $1 A+\cdots$ & $\because$ Anes Laboribor & 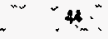 \\
\hline
\end{tabular}

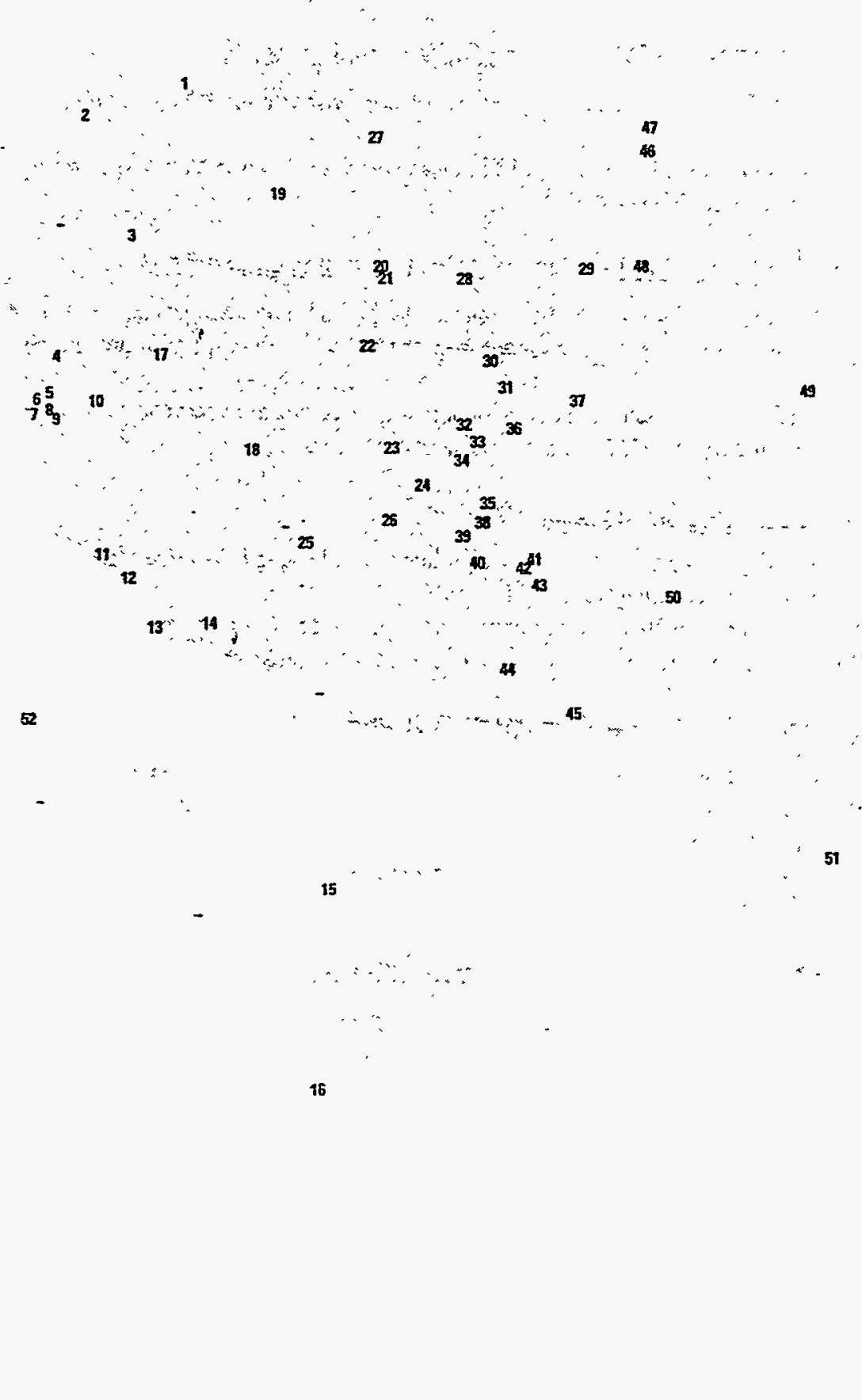




\begin{tabular}{|c|c|c|c|}
\hline \# & Location & Installation/Stite & $\begin{array}{c}\text { Page } \\
\text { Number }\end{array}$ \\
\hline 54 & Kansas City, MO & Xansas City Plant & 45 \\
\hline & 1 Hastancod, BO & L Lary Aponte Propesties & 4 \\
\hline & St Louis. MO & Weidon Spring Site & 45 \\
\hline & $S \log , 40$ & "St Lavis Airpoxt Veinty Propenty & 4 \\
\hline & St. Leuis, MO & St Louis Airport Storage Site & 48 \\
\hline & Stlowis. MO & St Lovis Downtown St: & 4 \\
\hline 56 & Chicago, IL & University of Chicago & 48 \\
\hline & Chicago, IL & Notignal Gund A Mnory & 48 \\
\hline 57 & Cook County, IL & $\begin{array}{l}\text { Sitz ANPlot M; Palos Natrons! } \\
\text { Preserve }\end{array}$ & 4 \\
\hline & Batersa, if & Formitabortory & 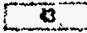 \\
\hline & Lement, IL & Argorna National Laboratory East & 43 \\
\hline 5 & Grante Ciky ol & Grame bity Steal & 8 \\
\hline 59 & Madison, IL & Medison & 48 \\
\hline 60 & Hataesture us & 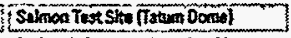 & 58 \\
\hline 61 & Paducah KY & Paducoh Gaseous Ditfusion Plant & 55 \\
\hline 6 & Hivaro, N & Maxay Fits ouspostisin & 5 \\
\hline 63 & Ook Rudge. IN & Y-12 Plant & 49 \\
\hline & Oakpidge, n & $102 \mathrm{kndiggk-25}$ & 3 \\
\hline & Ouk Bidge.TN & Oak fidge National La beratory & 49 \\
\hline H & $02 \times d s=, \pi$ & Eke Gato & 39 \\
\hline 65 & Adrien, MI & General Motors & 48 \\
\hline 6 & Luckn of & Misekny & 4 \\
\hline & Toledo, $\mathrm{OH}$ & Baker Brothers & 49 \\
\hline 6t & Prow, oll & 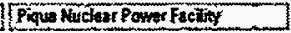 & 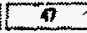 \\
\hline 68 & Mianisburg, $\mathrm{OH}$ & Mound Plant & 48 \\
\hline$\infty$ & Oxderd, OH & Asterafiloxfod & 49 \\
\hline 70 & Faiffeld, OH & $\begin{array}{l}\text { Associated Airerath and Tool } \\
\text { Manufacturing }\end{array}$ & 48 \\
\hline$\pi$ & Frneld, OH & 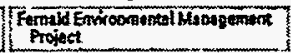 & 71 \\
\hline$\pi$ & Paineswitle, OH & Poinesvilte & 48 \\
\hline 73 & 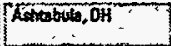 & 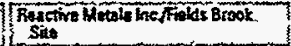 & 47 \\
\hline 74 & $\begin{array}{l}\text { Columbus, OH } \\
\text { Columbus, OH }\end{array}$ & $\begin{array}{l}\text { Batretie Cohumbus Le boratory } \\
\text { B\&T Meuls }\end{array}$ & 48 \\
\hline$\sqrt{75}$ & Fortanoudh of & Portmpot Gartout Dinusion Plent & 6 \\
\hline 76 & Niagara Falls, NY & Nagara falls Starage Sito & 60 \\
\hline$n$ & 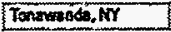 & Seawayladontrool Park & 59 \\
\hline & Tonawranda, NY & Ashland 011 & 59 \\
\hline & Tronmandaxy & Irachen: & 5 \\
\hline & Tonswanda, NY & Linde Air Products & 59 \\
\hline 78 & Buitio, AT & 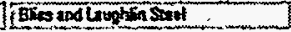 & 3 \\
\hline 79 & West Valley. NY & Wost Valley Demanstration Project & 5 \\
\hline 8 & Lenstan NY & 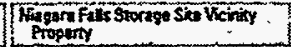 & 59 \\
\hline 81 & Colonie, NY & Colonie & 60 \\
\hline & Sebenectady 1 I & 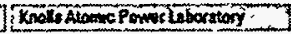 & 58 \\
\hline 82 & Menhatten NY & Baker and Witiams Warohouse & 59 \\
\hline$\$$ & $1 \mathrm{ptan}, \mathrm{n}$ & 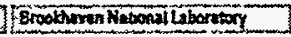 & 5 \\
\hline 84 & Asquippa, PA & Asiquippa forge & 59 \\
\hline$E$ & Cancendourg is & Coneosbur? & 52 \\
\hline 85 & Shippirgport PA & Shippingport Atomic Power Station & 58 \\
\hline$\theta$ & Spropolo,,$P A$ & CHSetroos & 5 \\
\hline & West Mitition, PA & Betis Atomic Power Loboraton & 58 \\
\hline 8 & Conts Bny, & Wî. Graes 2 Company & S \\
\hline 89 & Aiken.SC & Savennah Piver Sate & 52 \\
\hline 9 & 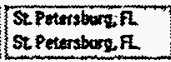 & 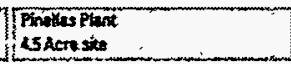 & 54 \\
\hline & Largo. F & Pesk OU Petroleum Refinirg Plant & 55 \\
\hline 9 & Moysere, PR & 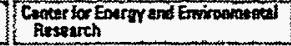 & 3 \\
\hline 92 & Norton, MA & Shpack Landtia & 59 \\
\hline 9 & Inden Orchurd HA & Chaponen Vero & 9 \\
\hline 34 & Bevesty, MA & Ventron & 59 \\
\hline 5 & Benponu, CT & 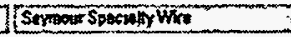 & 5 \\
\hline 96 & Wendsor, CT & CESito & 59 \\
\hline$g^{2}$ & Jerany $E_{y, 4 I}$ & Retexphepote & sis \\
\hline $\mathbf{8 B}$ & Middtesex ins & Middiesex Municipal Land5il & 59 \\
\hline 9 & 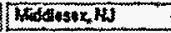 & Axdaterex 5aes;ing Plast & 9 \\
\hline 100 & New Brunswick, NJ & Neve Brunswick Laberatory & 60 \\
\hline In & Mormod, HW & 7 Maymoed Chandal Whats & $\infty$ \\
\hline 102 & Womerpequannock & Wayne & 60 \\
\hline 163 & Prixaton, NI & 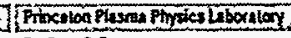 & 36 \\
\hline 104 & Deepwates, NJ & Du Pant \& Comp & 59 \\
\hline
\end{tabular}

Note: Some numbered locations represent more than one site. 


\section{Contents}

1 National Program 1

2 Site Summaries Overview 13

3 Northwestern Site Summaries 15

4 Southwestern Site Summaries 27

5 Central Site Summaries 41

6 Eastern Site Summaries 49

7 Performance and Funding Data 61 


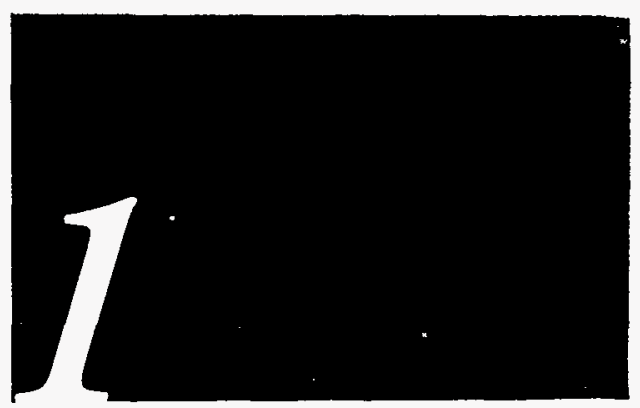

\section{National Program}

\section{Overview}

The Department of Energy's Environmental Management program was created in 1989 to manage waste and cleanup contamination produced as a result of 50 years of nuclear weapons producrion and research at 137 Department of Energy sites in 33 States and-1 territory. These sites comprise a combined area of approximately 3,300 square miles. The Department faces the enormous task of addressing nearly 10,000 individual remediation challenges throughout the entire complex.

For example, almost one million cubic meters of radioactive waste and materials must be safely managed until treatment and disposal facilities are available. Over 7,000 contaminated buildings that the Department owns are no longer needed, and they require expensive monitoring and surveillance until they can be safely dismantled.

The size and scope of work varies greatly from site to site within the complex. Several billion dollars have already been spent on assessing problems and addressing urgent risks. However, essential decisions remain to be made. These decisions include determining what level of residual risk the Nation is willing to accept and consequently how much money will be required for clean up, where waste management facilities will be located, how much will be remediated at each site, and what technological - developments can be proven. In addition, the program must meet a growing number of regulatory requirements. As the program continues to move out of the assessment phase and perform an increased amount of remediation, funds must be available to accomplish this work.

Environmental Management made significant improvements in program management and progress in meeting its enforceable agreement milestones in 1994. In 1993, the program completed 73 percent of its enforceable agreement milestones. Environmental Management completed 87 percent, or 380 of its 1994 milestones. In addition, 19 milestones that were scheduled for 1995 were also completed. The performance of each program element is described in more detail throughour the report.

The Environmental Management program budget for 1996 reflects the program's efforts to incorporate the use of prior years' balances, performance-based budgeting, and productivity savings into all program activities. The program will implement an estimated 
Nine Enforceable Agreement Milestones were more than 6 months overdue in 1994:

Delays from regulators, or delays in receiving approval, contributed to in two enforceable agreement milestones; changes in scope affected three milestones; and uncontrolled or unexpected delays, renegotiations, reprioritization of priorities, and delays in preceding milestones each contributed to Overdue Enforceable Agreement Milestones.
$\$ 1,046$ million in productivity savings and contractor reductions into its 1996 budget and utilize $\$ 300$ million from prior year's balances. The increasing number of sites being transferred to Environmental Management from other programs within the Department of Energy is reflected in the large increase in the Nuclear Marerial and Facilities Stabilization program budget. Activities to manage waste across the complex consumes the largest share of Environmental Management's budger, $\$ 2.7$ billion, in 1996. Funding to accelerate research efforts in waste characterization and remediation technologies in 1996 is $\$ 390$ million.

Environmental Management's major responsibilities are described in the following sections. They include compliance with environmental regulations, waste management, environmental restoration, technology development, nuclear marerial and faciliries stabilization, safety and health, and public . accountability.

\section{Environmental Regulations}

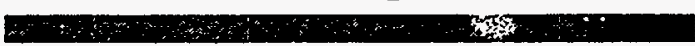

Almost 80 percent of the Environmental Management budget request for 1996 is specifically directed to meet requirements of compliance agreement milestones and environmental regulations. Enforceable agreement milestones dictate schedules of activities that are required by a permit or agreement. In 1994, the Environmental Management program was charged with meeting 437 milestones. It met 399, including 19 milestones due in 1995 that were completed early. Milestones were missed primarily due to the discovery of new problems or inadequate knowledge of the problem when establishing milestones. When a milestone is missed, regulators can take a variety of actions, including assessing fines and penalties or seeking injunctions.

Environmental Management is committed to meeting the requirements of all compliance agreements, as well as improving the efficiency and effectiveness of the program to ensure the safety of workers, the public and the environment. The program's commitment to meet these regulatory requirements and other responsibilities continue to

\section{Performange Measurement:}

Environmental Management is a pilot program for the Government Performance and Results Act, passed in 1993. The Government Performance and Results Act addresses Congress' concern that Government agencies are handicapped by a lack of well-defined program goals and results-oriented performance information, making it difficult for Congress to hold programs accountable for achieving effective results. To help resolve this issue, the Government Performance and Results Act requires that Federal agencies increase their emphasis on the outputs, outcomes, and results of projects. This goal will be achieved through: (1) Strategic Plans that articulate each program's mission and provide long-term goals to implement the mission; (2) Performance Plans that provide the direct link between the Strategic Plan goals and day-to-day activities and (3) Performance Reports that relate the actual dollars spent against the goals set in the previous year's Performance Plan. Environmental Management is committed to achieving these performance-based goals and implemented an aggressive performance measurement plan 1994. The Performance Plan, submitted to the Office of Management and Budget in May 1994, takes into account the long-range goals of the program's Strategic Plan. Specifically, the performance measures focus on timeliness, quality, customer satisfaction, and cost per output unit. An example of a performance-based initiative is using the Progress Tracking System to develop quarterly reports on cost and schedule performance reports. Comparing these quarterly reports to the expectations set in the annual Program Plans will serve as the basis of the performance-based review that, along with results from other initiatives, will be included in the 1994 Performance Report that is due to the Office of Management and Budget in March 1995. The 1995 Performance Plan was submitted to the Office of Management and Budget in January 1995, and the draft plan for 1996 is due in the spring of 1995. 


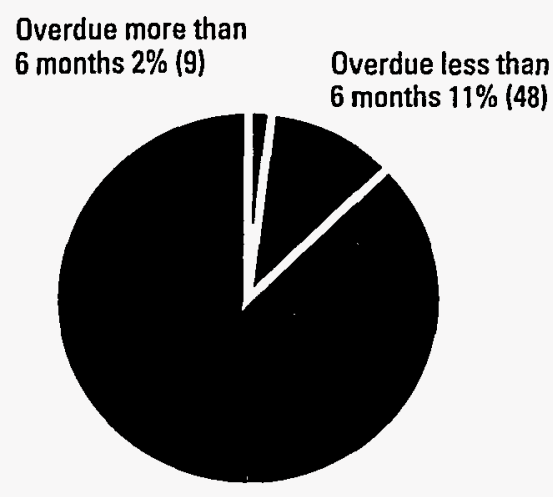

Complete 87\% (399)

Figure 1. Enforceable Agreement milestones status through September 1994

grow, while the budget does not. For this reason, - the program is reviewing its compliance agreement commitments internally to determine whether milestones might be accelerated, delayed, or modified based on condirions established by the program. These conditions include milestones that might be unnecessarily protracted, do not address health risks, no longer have a strong technical justification, could be better coordinated with other projects, or should be modified because of the changed mission or operation of a facility. When changes are identified, Environmental Management will enter into negotiations with its regularors and stakeholders. The program is commitred to meeting all milestones until these changes are approved. This milestone analysis is part of a larger effort to improve the efficiency and effectiveness of the Environmental Management program. Environmental Management is developing a strategy to ensure that stakeholders are involved in reviewing all enforceable agreements.

\section{Waste Management}

The Environmental Management program is commonly referred to as a "cleanup" program; however, more than 50 percent of the program's budget was spent for waste management activities in 1994. Environmental Management's Waste Management program mission is to treat, store, and dispose of the waste and manage the spent nuclear fuel generated during weapons processing and manufacturing, research activities, and site remediation activities. Currently, Department of Energy facilities house more than one million cubic meters of radioactive waste, and different types of waste are located at many sites nationwide.

In 1995, as in 1994, the Department will continue to maintain the safe storage of 397,000 cubic meters of previously generated high-level waste and 106,000 cubic meters of transuranic waste. The Department has treatment facilities for high-level waste under construction in South Carolina and New York. These facilities are expected to begin treating radioactive waste in 1996. In both 1995 and 1996, the primary emphasis of the Waste Management program will be to eliminate threats to human health and the environment at Environmental Management sites and to demonstrate tangible results.

Environmental Management is also responsible for coordinating waste minimization and pollution prevention efforts for the entire Department. Waste minimization programs and activities were initiated at all sites by 1991, and in 1994, the Department issued a comprehensive Waste Minimization/ Pollution Prevention Crosscut Plan. The Plan outlines program activities that sites must implement to meet the Department's waste reduction goal. Secretary O'Leary is committed to a 50 percent reduction in the amount of toxic waste that the Department's facilities routinely produce, by 1999 . In order to meet this goal, and continue waste reduction and recycling efforts established by Executive Orders, the Department has spent over $\$ 34$ million in 1994, and expects to spend over \$57 million in 1995. This increase in spending is expected to result in significant savings in future waste disposal costs for the Waste Management program.

The Department must overcome technical challenges to build facilities needed for safely managing and disposing of waste generated at its sites. Plans must balance the relative costs with risks of transporting waste from one site to another, storing waste onsite, building facilities, and ensuring worker safety while handling waste. Two related activities are underway that will affect future decisions for managing waste. The Department is undertaking a very broad, or programmatic, environmental impact analysis of alternative strategies for waste management in the Waste Management Programmatic Environmental Impact
Waste Management's Overall Performance in 1994:

Waste Management completed 127 of 129 milestones (99 percent), which is an 11 percent improvement over 1993. Waste Management also reduced urgent risks at Departmental sites across the complex. At Hanford, the program exceeded the goal of completing 14 of 24 Secretarial safety initiative actions by completing 23 activities. 
The United States' Nonproliferation policy is to minimize the use of highly enriched uranium, which can be used to develop nuclear weapons. From the 1950's to 1980's, the United States provided highly enriched uranium to other countries for use in foreign research reactors. In exchange for U.S. assistance in developing peaceful applications of nuclear technologies, foreign countries were encouraged to forgo development of nuclear weapons. Several operators of these foreign research reactors have run out of storage capacity and must return this spent nuclear fuel to the United States or be forced to shut down or reprocess, or recycle, this fuel-a process the United States does not promote because of the potential security risks. The United States is therefore considering accepting responsibility for storing this spent nuclear fuel to prevent this fuel from being used to produce nuclear weapons.
Statement, developed in accordance with the provisions of the National Environmental Policy Act. The final document will be issued in the fall of 1995. The draft Waste Management Programmatic Environmental Impact Starement will be released in the spring of 1995.

The Department is also working closely with States, Indian Nations, local governments, the Environmental Protection Agency, and concerned citizens to develop effective site treatment plans for mixed waste. These plans will outline how the Department intends to treat mixed waste and meet the many requirements of the Federal Facility Compliance Act of 1992. In October 1993, the Department completed Conceptual Site Treatment Plans, followed by Draft Site Treatment Plans in August 1994. The plans must be made available to public, and approved by a regulator; either by the state where the mixed waste is generated or stored, or the Environmental Protection Agency. In' April 1995, the Department will submit proposed Site Treatment Plans to the States and Environmental Protection Agency for approval, reflecting input on the Draft Plans.

The Waste Isolation Pilot Plant, located near Carlsbad, New Mexico, was specifically designed and constructed for disposal of defense-generated transuranic waste. Tests are now underway to determine whether the facility meets all . requirements, including criteria established by the Environmental Protection Agency. The decision to choose the Waste Isolarion Pilor Plant as a permanent disposal facility for disposing of transuranic waste will be based on a thorough evaluation of test results, informed public participation, and regulatory compliance. The Department will have spent $\$ 920$ million between 1990 and the end of 1995 to complete construction and conduct tests. The Waste Isolation Pilot Plant is described in more detail beginning on page 31 .

The safe storage of spent nuclear fuel has become a vital issue for Environmental Management. Abour 2700 metric tons of spent fuel from the Department's test and materials production reactors, the U.S. Navy's propulsion reactors, university research reactors, and foreign research reactors is currently accumulating in storage facilities. Environmental Management is seeking inpur from concerned cirizens and regulators to develop a strategy for the interim storage of spent nuclear fuel in the Department's storage facilities.

In June 1994, the Department released a twopart draft Environmental Impact Statement covering spent fuel management throughout the United States as well as remediation and waste management at the Idaho National Engineering Laboratory. The Final Environmental Impact Statement and Record of Decision will be completed by June 1, 1995. These Environmental Impact Statements will provide the specific

\section{Estimating the Mortahe for the Bold War: The Baseline Envibonmental Manalgement Report}

Congress directed the Department of Energy to provide a report by March 1995, and annually thereafter, on the total cost for the environmental management of the Nation's nuclear weapons complex. The law requires that the report include the annual budget requirements to meet compliance commitments, the total cumulative costs, and the required tasks. The Federal Government last estimated the total cost of environmental liabilities at Department of Energy facilities in 1988, prior to the end of the Cold War, when the renovation and indefinite operation of the existing nuclear weapons complex was still being contemplated.

The actual cost of dealing with the environmental problems at nuclear weapons facilities will depend on a variety of factors. The first report analyzes the impact of: land use, residual contamination standards, technology development, funding, schedule, and pace, in addition to the configuration of waste treatment and disposal facilities to be built. The central cost estimate was developed using "basecase" assumptions for each of these factors. In addition, sensitivity analyses help identify how each factor affects overall costs. The report will provide useful insights to guide future policy decisions and be an essential part of the constructive national debate of the issues called for by Assistant Secretary Thomas Grumbly. 
information and analyses needed to help decisionmakers understand the potential environmental consequences of alternative policies and management approaches. A draft Strategic Plan for spent fuel management was released in December 1994.

In addition, the Department is soliciting public comments on proposed plans to accept spent nuclear fuel from foreign countries if that fuel contains enriched uranium previously exported by the Unired States. In 1994, the Department completed an Environmental Assessment on the Urgent Relief Acceptance of Foreign Research Reactor Spent NucleaF Fuel. One shipment of 153 spent-fuel elements was received at Savannah River Site in September 1994. The Department will issue a Draft Environmental Impact Statement for Foreign Research Reactor Spent Nuclear Fuel in early 1995. The Department will also ask the public to comment on options for receiving, transporting, and temporarily storing this fuel.

The Final Environmental Impact Statement and Record of Decision will then be issued in late 1995. A total of $\$ 2.7$ billion is requested for waste management activities in 1996.

\section{Environmental Restoration}

Environmental Restoration's mission is to protect human health and the environment by addressing contaminated soil, ground water, surface water, structures, and other material at Environmental Management sites. Environmental Restoration is managed as 17 primary projects throughout the country, subdivided into smaller subprojects. These 850 subprojects include activities at National Priorities List sites, commonly referred to as Superfund sites; decontamination and decommissioning projects; Uranium Mill Tailings Remedial Action Project (UMTRA) sites; and Formerly Utilized Sites Remedial Acrion Program (FUSRAP) sites. Other responsibilities include necessary landlord, oversight, surveillance and maintenance, and technical assistance to supporr the remediation work.

For each subproject, the Department characterizes the problems to determine an appropriate course of action. Regulators and other stakeholders are involved in this process at all levels, including direct oversight as members of advisory boards and through public meetings. The characterization process includes sampling and analysis, modeling, evaluation of historical records, and studies of appropriate remedial alternatives. When site characterization is complete, the Department, with regulators and stakeholders, determines the appropriate remediation strategy. At the end of 1994, assessment of 282 subprojects was completed. The program plans to spend close to $\$ 592$ million to complete 78 assessments in 1995 and continue the assessment of over 100 subprojects. Once site characterization activities are completed, a final remedial alternative is selected and remediation begins. In 1994, remediation ar 31 subprojects at 20 sites was completed. Across the Nation, more than $\$ 536$ million will be targeted for the remediation and decontamination and decommissioning activities in 1995 necessary to complete 28 activities.

At all sites where environmental management activities are conducred, interim actions are used to address urgent risks and remove potential threats prior to the completion of detailed characterization studies. In 1294, the program completed 119 of these actions. In 1995, the Department intends to complete another 100 interim actions, bringing the total to more than 500 since the program was established.

Over half the sites in the Environmental Management program are managed under UMTRA and FUSRAP projects. The UMTRA Project manages 24 former uranium ore processing sites that are contaminated with tailings and other byproducts of uranium mining and milling operations. In addition, thousands of vicinity properties were contaminated by windblown waste or debris used in construction or landscaping. By September 1994, remediation at 13 of 24 mill tailing sites was completed. In 1995, remediation will continue at five sites and will be initiated at four sites. Remedial action will be initiated at the final two sites in 1996. All surface contamination within the 10 States and 2 Indian Tribal lands should be remediated by 1997, except for the vicinity properties at Grand Junction. Descriptions of activities at these sites can be found in the site summary sections of this report.

Additionally in 1994, the UMTRA Project completed scoping meetings associated with the development of the Programmatic Environmental
Overall Environmental Restoration Performance in 1994

Environmental Restoration completed 250 of 305182 percent/ of its Enforceable Agreement milestones through September. Environmental Restoration completed 62 of 80 assessments during 1994, reaching 78 percent of the goal. The Environmental Restoration program planned to complete 29 interim actions and 12 remedial actions, and these goals were surpassed with 119 interim actions and 31 remedial actions completed. In addition, nine decontamination and decommissioning projects were completed, exceeding the five projected projects planned. 
Technology Development Performance in 1994

Technology Development showed dollar for dollar leveraging with industry and agencies outside of the Department and made 24 technologies available to transfer to the private sector, meeting all strategic plan goals for 1994.

\begin{tabular}{l}
\hline Technology Development \\
Focus Areas \\
-Contaminant Plume \\
Containment and \\
Remediation \\
- Mixed Waste \\
Characterization, \\
Treatment, and Disposal \\
-Radioactive Tank Waste \\
Remediation \\
-Landfil Stabilization \\
-Facility Stabilization, \\
Decommissioning, and \\
Final Disposition \\
\hline \hline
\end{tabular}

Impact Statement for ground-water compliance. In 1995, the Programmatic Environmental Impact Statement will be made available to affected States and Indian Tribes. Once the Record of Decision has been published, the UMTRA Project will begin working on identifying ground-water compliance strategies for each of the UMTRA sites.

Under FUSRAP, remediation actions are managed at 46 sites in 14 States where the Federal Government contracted with private firms to process or perform research in connection with the Department's atomic weapons activities. In 1994, remediation was completed at 3 sites, bringing the toral completed to 16 . An additional 3 sites will bè completed in 1995, and another 3 sites are expected to be completed in 1996. Remediation at the balance of the FUSRAP sites is planned to be complered by the year 2016. A description of activities at these sites can be found in the site summary sections of this report.

\section{Technology Development} Fans

Environmental Management faces many technological challenges in meeting its remediation and waste management goals and complying with environmental regulations. In some cases, a proven technology is not yet available for remediating a specific type of contamination. In other cases, existing technology may not comply with regulations or does not satisfy public requirements for safety and risk management. To address these needs, the Technology Development program researches new and innovative technologies to meet Environmental Management's needs. Technology Development works hand-in-hand with other programs within the Department of Energy, other Federal agencies, national laboratories, universities, and the commercial sector to maximize research efforts and ensure safe and efficient cleanup. Its goals are to develop technologies that make remediation better, faster, cheaper, safer, and in compliance with existing regulatory requirements. In many cases, development of new technologies presents the best hope for ensuring a substantive reduction in risk to workers and the environment. The transition of technologies into more advanced stages of development is based on technological, regulatory, economic, and institutional criteria.

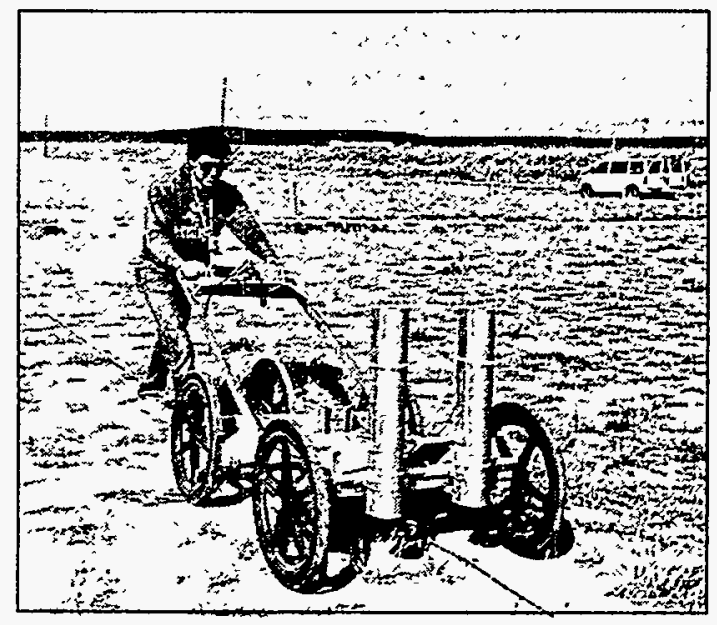

The Rapid Geological Surveyor can perform geophysical magnetic surveys quicker and more economically than hand-held instruments.

Within the weapons complex, technology development programs are organized to focus on the five major remediation and waste management problem areas. These focus areas (listed in the sidebar on page 7) have been targeted for action on the basis of risk, prevalence, or need for technology development to meet environmental requirements. In the future, additional areas may be added, or currently identified areas further partitioned, to ensure that research and technology development programs remain focused on Environmental Management's most pressing remediation and waste management needs.

Most sites have insufficient information concerning the distribution and concentration of uncontained hazardous and radioactive contaminants present in soil and ground water throughout the Department's weapons complex. The migration of some contaminants threatens water resources and, in some cases, has already had an adverse impact on the offsite environment. Many of the current characterization, containment, and treatment technologies are either ineffective or too costly. Improvements are needed in characterization and data interpretation methods, containment systems, and in situ treatment of waste.

The Department faces major technical challenges in the management of low-level radioactively contaminated mixed waste. Several conflicting regulations and a lack of definitive mixed-waste treatment standards hamper ongoing 
activities. In addition, disposal capacity for mixed waste is expensive and severely limited. The Department spends millions of dollars annually to store mixed waste due to the lack of accepted treatment technology and disposal capacity. Currently approved waste management practices require time consuming and costly waste characterization before disposal. Therefore, the Department is developing technology that leads to better and less expensive characterization, retrieval, handling, treatment, and disposal of mixed waste.

Across the complex, hundreds of large storage tanks containing hundreds of thousands of cubic meters of high-level radioactive waste present a problem that has received much attention. Primary areas of concern are deteriorating tank structures and the potential leakage of contents if not corrected. Research and technology development activities focus on the development of methods for characterization, retrieval, treatment, and final disposal of the waste in these tanks.

Numerous Department of Energy landfills pose significant remediation challenges. Some existing landfills have contaminants that are migrating, therefore requiring interim containment prior to final remediation. Materials buried in "retrievable storage" pose another problem - the need for retrieval systems that reduce worker exposure and the quantity of secondary waste. In addition, development of in situ methods for both containment and treatment is a high-priority need.

The age of the Department's weapons complex facilities and the reduction in nuclear weapons production have resulted in a growing need to transition, decommission, deactivate, and dispose of numerous facilities some contaminated with radionuclides and hazardous materials. Many uncontaminated building and scrap materials exist at the sites providing a potential resource with a significant economic value. However, current regulations lack clear standards and thus indirectly discourage the recovery, recycling, or reuse of these resources. Development of enhanced technologies for the decontamination of these materials and -effective communication of the low relative risks involved are promising avenues toward meeting those recovery and recycling goals. In addition, material removal, handling, and processing technologies must be improved to enhance worker safery and reduce cost.

One example of an integrated effort with industry and universities is the Oak Ridge National Laboratory and Sandia National Laboratories working together to design, fabricate, and integrate the remotely operated Dual Arm Work Module. This module was developed to safely and efficiently

\section{Transportation and EMERgengy MANagement:}

The Department of Energy transports its highly radioactive materials, such as spent fuel from research reactors and radioactive materials resulting from defense activities, isotope production, storage, and other facilities, throughout the United States. In 1994, the Department began shipping cesium chloride capsules from Northglenn, Colorado, to the Hanford Site in Washington State. Extensive coordination and planning with the Western Governors' Association, Umatilla Indian Tribe, and State officials contributed to safe and uneventful shipments. Environmental Management is working with regulators and stakeholders to design and implement a very effective transportation program to transfer the Department's radioactive and other hazardous materials from its sites to treatment and storage facilities across the Nation. The Transportation program constantly evaluates and conducts operational assessments of sites and carriers to ensure that safe transportation practices are followed. The program also provides training and assistance, develops and implements innovative computer systems to manage the Department's transportation business and track shipments, supports research and development in packaging radioactive materials, and supports program evaluations of risk in environmental assessments and environmental impact statements. Emergency Management procedures to plan for, respond to, and mitigate incidents or emergency situations at Environmental Management facilities, and transportation to and from facilities, are also developed by this office. Transportation and emergency management works regularly with other institutions and the general public to ensure awareness of these transportation activities and emergency procedures. 


\section{Reusing Building} Material

The Environmental
Protection Agency is
currently drafting
guidelines to define clear
standards that encourage
the recycling and reuse of
building material, but a
final document for
implementation is not
expected until 1996. Until
clear guidelines are
implemented, the
Department will continue
to approach all
remediation efforts on a
case-by-case, site-by-site
basis under the guidelines
of CERLCA.

The Environmental Protection Agency is currently drafting guidelines to define clear the recycling and reuse of building material, but a final document for implementation is not clear guidelines are implemented, the Department will continue to approach all case-by-case, site-by-site of CERLCA. maneuver tools to dismantle radioactive materials and equipment. Initial testing was successful and will be followed by comprehensive performance evaluations with industrial partners. Also in 1994, the Savannah River Site initiated its Technology Transfer and Economic Development Program. The objectives of this $\$ 30$ million, 1-year program are to develop and transfer new and existing environmental remediation rechnologies to the private sector to provide economic stimulus to the region surrounding the Savannah River Site. Alliances with regional universities and businesses have been formed, and an Environmental Technologies User Facility and an Analytical Center for Environmental Sciences are also being established to promote technology transfer and economic development.

Major plans for 1996 include increasing demonstration, testing, and evaluation of in situ containment and stabilization technologies for buried waste and demonstrating imaging technology inside high-level waste tanks for use during the foggy conditions of low or no visibility expected during retrieval operations. At the Oak Ridge K-25 site, the Department will perform a full-scale demonstration of a six-step process that incorporates existing decontamination and separations technologies into an integrated system to separate hazardous constituents from structural and process equipment components. The Fernald site will demonstrate an in situ analysis method developed to determine the level of radioactive and hazardous contaminants in concrete floors. The Department will also perform several demonstrations of reactive subsurface barriers to prevent offsite migration of radionuclides and mixtures of radionuclides and organics.

\section{Nuclear Material and Facilities Stabilization}

The end of the Cold War and the shift in the Department of Energy's focus from nuclear weapons production to environmental management has resulted in a need to shut down a number of defense production facilities that are no longer needed. The Office of Nuclear Material and Facilities Stabilization, formerly known as The
Office of Facility Transition and Management, was established in 1992 to coordinate and oversee the orderly transition of contaminated installations and facilities from other Departmental program organizations to the Environmental Management program. Approximately 25 percent of the total Environmental Management budget request for 1996 is earmarked to address the technical, socioeconomic, institutional, and administrative issues involved in transferring, stabilizing, decontaminating, and determining the ultimate disposition of surplus facilities.

It is not possible to immediately or simultaneously shut down, or decommission, all of the approximately 21,000 surplus facilities the Department manages due to the tremendous financial resources needed, health and safety measures involved, and the economic impact on surrounding communities. However, the Department has developed a strategy to deactivate facilities on a priority basis to ensure that as many facilities as possible are placed in a safe, stable condition so they can be monitored and maintained for an extended period while awaiting final decommissioning. The Department then applies its resources to accomplish the most, in terms of facility safery, in the shortest amount of time. This strategy has proven greatly effective at Hanford, where the 1994 planned workscope on the Plutonium and Uranium Extraction Facility and Uranium Trioxide Facility, for example, was completed ahead of schedule.

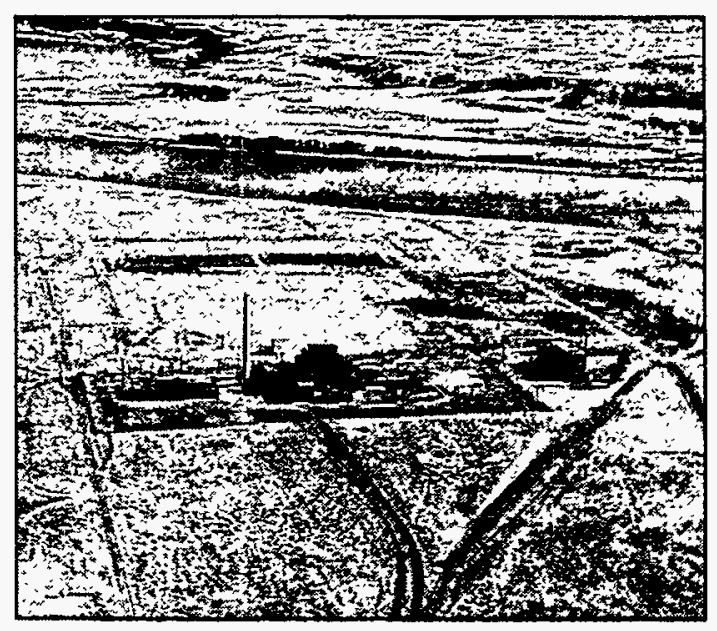

Aerial view of an area at Hanford after decommissioning. 
The program has provided staff support to the Department's Task Force on Worker and Community Transition in an effort to mitigate the adverse impacts to those communities and workers directly affected by the downsizing of the weapons complex. On September 15, 1994, Secretary O'Leary created the Office of Worker and Community Transition, reporting directly to the Under Secretary of Energy. This office will serve as a focal point for addressing labor issues associated with the changing mission of the Department and will demonstrate the Administration's commitment to assist those communities and workers who played a vital role in ending the Cold War through nuclear weapons production activities. The Office of Nuclear Material and Facilities Stabilization will work closely with the Office of Worker and Community Transition to ensure that a costeffective transition process be conducted to benefit reuse of the facilities, rehiring of workers, and stabilization of the local economy.

In the last year, Environmental Management completed the Surplus Facilities Inventory and Assessment project, which identifies the current status of the Department's surplus facilities and those expected to be declared surplus over the next five years. The system will be continually updated. The program expects plans to be in place by 1995 to mitigate all urgent risks and threats identified during this initial surplus facilities survey.

Major facilities thar have been designated as surplus and transferred to Environmental Management include all the facilities at the Rocky Flats Environmental Technology Site, the Plutonium and Uranium Extraction Facility and Uranium Trioxide Facility at the Hanford Site, and the Idaho Chemical Processing Plant at the Idaho National Engineering Laboratory. The Oak Ridge National Laboratory Isotopes facility was transferred to this office in 1994, and preparations for transferring the Mound Plant and the Pinellas Plant to facilities stabilization were also completed.

In 1995, the program plans to deactivate major facilities at Rocky Flats, Hanford, and Idaho. In addition, by implementing streamlined planning measures and cost reductions, the program plans to reduce surveillance and maintenance costs by more than $\$ 1$ million. The benefits of these initiatives were demonstrated ar Idaho National Engineering Laboratory, where several management improvement initiatives designed to streamline construction processes, eliminate duplication, and strengthen managerial and financial control sitewide proved to be cost effective. In January 1995, responsibility for the entire Savannah River Site (except the $K$ Reactor) transferred to Environmental Management from Defense Program. A streamlined management process for deactivating surplus facilities will be developed, and in 1995 the program plans to issue the Deactivation Project Policies and Requirements Document for consistent determination of costs and schedules complex-wide. Other goals include establishing baseline risk assessments for workers and the public at Environmental Management sites, and ensuring that appropriare programs are in place to control and minimize any such risks.

\section{Safety and Health}

The Environmental Management program has made significant progress in ensuring that all activities proceed with adequare protection of the safery and health of workers and the public. Working with the Office of Environmental Safery and Health, the program is developing a comprehensive, standards-based worker health and safery protection program for Department of Energy sites performing hazardous waste activities. In 1994, the Department hired additional health and safety professionals to oversee the operations and enforce safery regulations. The program established more stringent training and qualifications requirements for its employees across the country and developed rechnical management plans for directing and monitoring support contractors. As a result, lost work hours at Department of Energy sites were reduced from 31.1 per year in 1993 to 23.2 in 1994 , resulting in a 30 percent reduction in work days lost due to injury.

Environmental Management is using several merhods to assess hazards within the complex. A team of nuclear safery, chemical, and radiation protection specialists, along with industrial hygienists, industrial and construction safery specialists, and toxicologists, is being used to determine actual hazards and make recommendarions to mitigate these hazards in Safery Analysis Reports and Health and Safery
Material and Facilities

Stabilization has

Identified Three Areas to

Measure Its Performance in 1995:

- Increase the number of facilities deactivated.

- Reduce surveillance and maintenance costs.

- Improve productivity and increase efficiency. 


\begin{tabular}{l}
\hline Six Areas the Office of \\
Compliance and Program \\
Coordination Will \\
Measure Its Performance \\
Against in 1995 \\
- Establish Environmental \\
Management-wide Site \\
Coordination Organization. \\
- Define parameters to \\
characterize safety and \\
health performance. \\
- Develop strategy for \\
enforcing occupational \\
safety and health \\
requirements for the entire \\
labor force. \\
- Review current \\
enforceable agreements \\
with stakeholder \\
involvement and \\
recommend changes to the \\
Secretary. \\
- Conduct 51 significant \\
appraisals and provide \\
technical assistance and \\
guidance resulting in \\
improved program \\
performance, \\
environmental \\
compliance, and \\
workplace safety and \\
health. \\
-Improve or maintain \\
Department of Energy \\
transportation safety \\
record. \\
\hline \hline
\end{tabular}

Plans across the Department of Energy complex. In 1994, the program instituted the Workplace Safety Improvement Iniriative. This initiative holds Headquarters and Operations Office Managers, contractors and subcontractors, and workers directly accountable for improving workplace safery and health. Under the Voluntary Protection Program, facilities are graded on their enforcement of health and safety procedure. This allows the Environmental Management program to focus its limited safety and health resources on those facilities that need the most support.

\section{Risk Management and Priority Setting}

Credible risk assessment and good risk " management are keys to the success of the Environmental Management program's six mission goals for protecting human health and the environment. In early 1994, the National Academy of Sciences prepared a report at the request of the Assistant Secretary to advise him on how risk-based decisions could be incorporated in the Environmental Management program. This report, "Building Consensus Through Risk Assessment, and Management of the Department of Energy's

Environmental Remediation Program," provided a blueprint for the development of a risk management program. In mid 1994,

Environmental Management created an Office of Integrated Risk Management to champion the implementation of the blueprint.

In January 1995, Under Secretary of Energy Charles Curtis issued interim Principles for Using Risk Analysis. These Principles provide initial guidance to the Department for defining risk analysis, its purposes, and the principles to be followed if it is to be done well and credibly. They also clarify the role of risk-based decisions in the Environmental Management Program by providing a specific frame work for risk assessment, risk management, risk communication, and priority setting.

The Office of Integrated Risk Management is responsible for ensuring that risk managemint and risk assessment theory and process are integrated into the program's decisionmaking process. The goals of these processes must be able to meet Departmental missions while protecting public health, worker health and safety, ecosystem viability, and cultural and natural resources through integrated risk assessment and risk management practices.

This office is developing a report to Congress that evaluates the risks to public health and safety that are addressed by compliance agreement requirements. This report will be used to help develop a mechanism to establish priorities among competing cleanup requirements. The report is due to Congress on June 30, 1995.

Specific long-range issues to be addressed by the Office of Integrated Risk Management may include ensuring that stakeholder values and stakeholderpreferred future use options are included in the risk assessment and risk management processes, that human health and environmental data and evaluations are independently reviewed, and that risk-related information is accessible and provided in a useful form to the public.

As part of this effort, Environmental Management placed a Notice of Program Interest in the Federal Register seeking to award grants or cooperative agreements to assist in developing credible processes and methods to support environmental management decisionmaking. The first awards will begin in early 1995.

\section{Public Accountability and Outreach Programs}

Environmental Management continued to work toward increasing public understanding of and involvement in program activities toward meeting its goal to enhance partnerships with its stakeholders in 1994. Site Specific Advisory Boards were established at eight sites in 1994 to advise on site-specific issues, such as future land use and remediation priorities within the site budget. Three more boards will be formed in the near future. The Citizen Advisory Board and other public groups had a key role in developing the Rocky Flats Strategic Plan and budget and planning baselines in 1994. The Environmental Management Advisory Committee was reconstituted in 1994 and became the Environmental Management Advisory Board, 
which will serve as a board of directors to advise Assistant Secretary Grumbly on various program issues.

Stakeholder involvement has led to tangible, demonstratable benefits to the Environmental Management program. For example, the Department and regulators recently cancelled the proposed closure of one waste area at Oak Ridge National Laboratory after stakeholders expressed concerns abour the high cost and minimal benefirs involved in the closure. As a result of stakeholder involvement in renegotiations of the Tri-Party Agreement at Hanford, the Department changed several critical aspects of the Agreement.

The program is also developing an environmental justice public participation strategy to ensure that stakeholders who may have been historically excluded from Environmental Management's decisionmaking process are included. A draft strategy has been released for public input.

There are three transportation stakeholder groups that exchange information and identify needs in order to enhance the Department's transportation and emergency preparedness activities. The Transportation Internal Coordination Working Group is an internal forum that serves as the coordination and consensusrecommending body to address and resolve issues within the Department. The Local Government
Network, a nonprofit corporation composed of State and local officials, offers workshops that provide interaction and discussion related to transportation activities along transportation corridors and contiguous to Departmental sites. The third group is the Transportation External Coordination Working Group, which includes representatives from approximately 30 national, State, Tribal, professional, technical, industry, and public interest organizations, plus Department of Energy representarives.

Environmeñtal Management has opened several information centers across the country in 1994 to help disseminate information to the public. The Formenly Utilized Sites Remedial Action Program established four communiry-based information centers to serve stakeholders in communities that are the focus of major remediation efforts. The Center for Environmental Management Information in Washington, D.C., continues to play a vital role in providing information about program acrivities. Accessible by a toll-free number (800-7-EM-DATA or 800-7368232), the Center houses a library of programrelated documents. In its first year of operation, the Center received more than 21,000 inquiries. Over 15,500 of these calls were made by individuals who contacted the Center for information about 1,000 newly-created Federal Environmental Management positions at sites across the country.

\section{ENUIRONMENTAL WANAgEMENT ADVISORY BOARD WEMBES}

Dr. John Ahearne, Sigma Xi
Mr. Alvin Alm, Science
Applications International
Corporation
Dr. Lynn Anspaugh, Lawrence
Livermore National Laboratory
Ms. Judith Areen, Georgetown
University Law Center
Mr. Richard Bangart, U.S. Nuclear
Regulatory Commission
Dr. Darryl Banks, World Resource
Institute
Mr. Dennis Bechtel, Nuclear Waste
Division, State of Nevada
Ms. Joan Bernstein, WMX
Technologies, Inc.
Mr. Jeff Breckel, Washington
Department of Ecology

Dr. John Ahearne, Sigma Xi Mr. Alvin Alm, Science Applications International Corporation Livermore National Laboratory Ms. Judith Areen, Georgetown University Law Center

Mr. Richard Bangart, U.S. Nuclear Regulatory Commission

Dr. Darryl Banks, World Resource

Division, State of Nevada Ms. Joan Bernstein, WMX Mr. Jeff Breckel, Washing
Department of Ecology

\section{American Indian Policy}

The Department has numerous facilities that are located on, near or adjacent to American Indian Tribal Lands. American Indian Tribes are sovereign nations that have a trust relationship with the Federal Government. In 1992, the Department developed its American Indian Policy to facilitate the fulfillment of the Department's responsibility to the Indian Nations. A principal component of the policy states that the Department is required to consult with Tribal governments near or adjacent to the Department's sites to solicit comments, hear concerns, and obtain advice from Tribal leaders regarding the Department's activities. 
In addition, the Department operates an extensive network of information centers at virtually all its sites to coordinate the dissemination of public information and outreach programs at those sites.
More than 20,000 people nationwide receive EM Progress, the program's quarterly newsletter. They include the general public, Congress, and State and local government officials. 


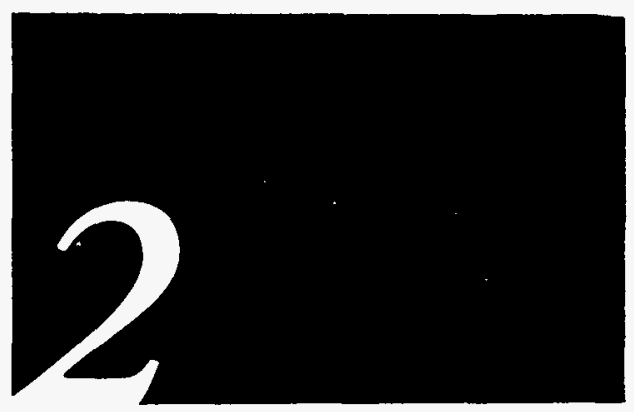

\section{Site Summaries Overview}

This section of the report presents a closer look at what the Department of Energy's Environmental Management program is doing around the country. Included are detailed discussions of the largest sites in the region, followed by site activities organized by State. A summary of activities at FUSRAP and UMTRA sites in the region can be found at the end of each regional section. FUSRAP and UMTRA sites are smaller sires that were either previously used by the Department of Energy's predecessor agencies to process or perform research on radioactive materials or by commercial facilities that mined and milled uranium.

As stated previously, regional groupings used for this report do not reflect any official Federal Government regional structure. These regional characterizations are only intended to help the reader identify and locate the sites of greatest interest.

In the following pages, you will read about the Department's performance in fulfilling requirements of the environmental statutes that include the National Environmental Policy Act, the Comprehensive Environmental Response, Compensation, and Liability Act, and the Resource Conservation and Recovery Act.
The National Environmental Policy Act (NEPA) provides a process for Federal agencies to identify and assess the alternatives to proposed actions to avoid or minimize the effect of these actions on the environment. Under this act, agencies must prepare an Environmental Impact Statement for all major actions that may significantly affect the environment. The act mandares agencies to involve the public and to make information available to Federal officials and citizens before decisions about selected alternatives are made. The selected alternative is documented in a Record of Decision.

The Comprehensive Environmental Response, Compensation, and Liability Act (CERCLA) imposes cleanup and reporting requirements for remediating hazardous waste sites. Under this act, the Department conducts Remedial Investigations and Feasibility Studies, which are usually performed together. The Remedial Investigation characterizes conditions at the site to identify the sources and extent of contamination. The Feasibility Study evaluates specific alternatives for cleaning up the site. The selected remedial action is documented in a Record of Decision.

The Resource Conservation and Recovery Act (RCRA) provides requirements for the management of hazardous waste. These guidelines regulate waste at all stages, from before it is generated until after its disposal. The act also 
establishes a permit program for hazardous waste storage, treatment, and disposal facilities. Permits identify the administrative and technical standards to which facilities must adhere.

In 1996, more than 86 percent of Environmental Management's budget will go directly to the field to perform environmental management activities. Each site was charged with improving its performance and meeting the objectives of the six strategic goals identified on page iv. This section includes general budget information for the sites described herein and an assessment of the performance of Environmental Management's major sites. Detailed funding information about the sites can be found in the Performance and Funding Data secrion of this report, beginning on page 61 .

- DOE Sites

UMTRA Sites

A FUSRAP Sites

U.S. Map broken out by the regions used in this report. 

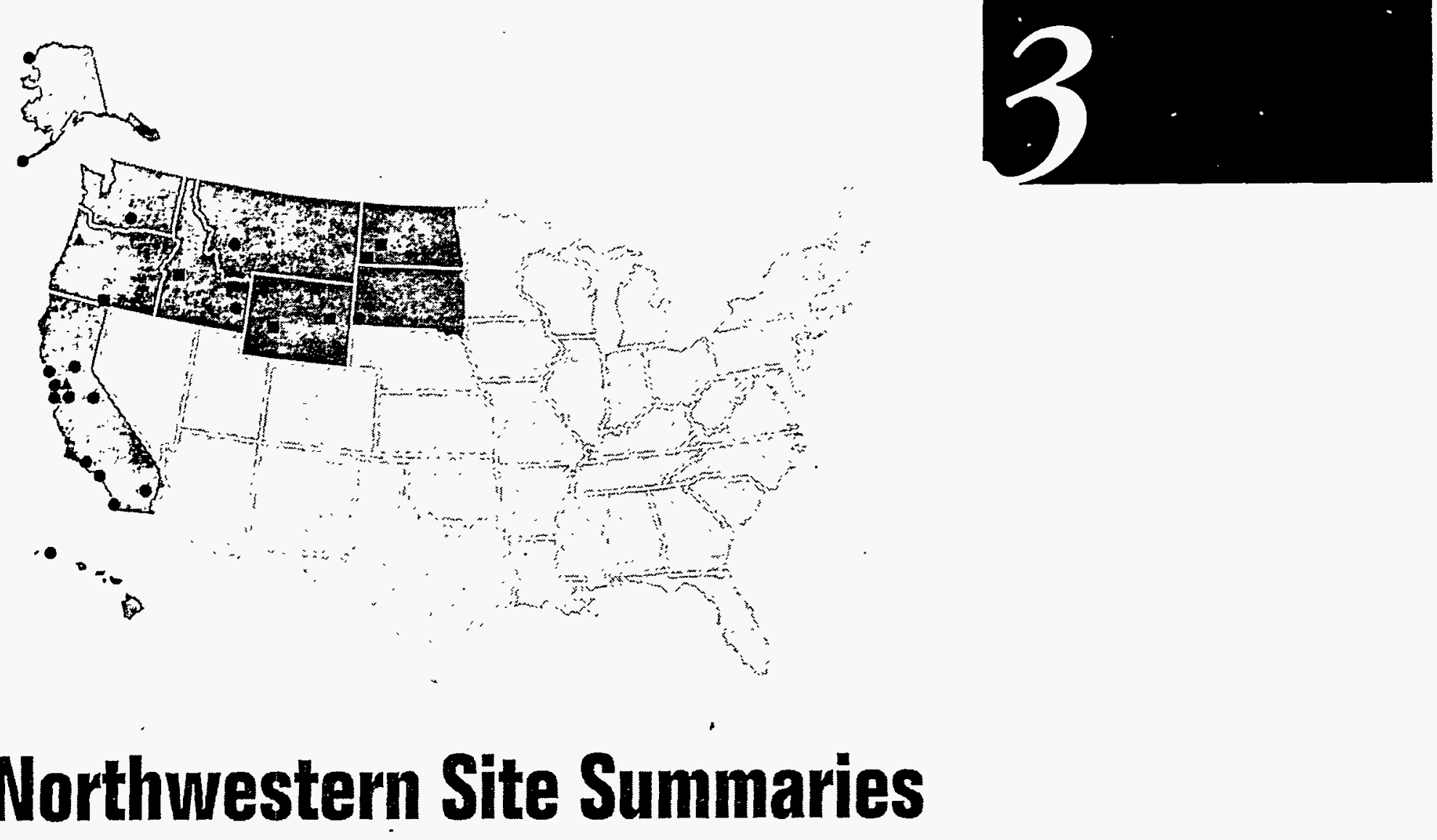

\section{Northwestern Site Summaries}

Hanford Performance in 1994:

Hanford was less than three percent over budget, and less than eight percent behind schedule in 1994. Nearly half of the entire site was remediated, and several decontamination and decommissioning and remedial actions were completed ahead of schedule.
For the purposes of this report, the Northwestern region includes Alaska, California, Hawaii, Idaho, Montana, North Dakota, Oregon, South Dakota, Washington, and Wyoming. The major sites in this region are Hanford in Washington and the Idaho National Engineering Laboratory in Idaho. The FUSRAP and UMTRA projects have several sites in the region and are discussed beginning on page 24. This section includes-general budget and performance information for each of the sites. More detailed funding data is provided in the Performance and Funding Data beginning on page 61.

\section{Hanford, Washington}

The Hanford Sire is 560 square miles of semi-arid land in southeastern Washington, about 50 miles north of the Oregon border. The Columbia River flows through the Hanford Site. The U.S. Army Corps of Engineers selected this area to build nuclear reactors and chemical processing facilities for the production, separation, and purification of plutonium in 1943. Today, the primary mission at
Hanford is the remediation of the site. On May 15, 1989, a Tri-Party Agreement was signed between the Department of Energy, the Washington State Department of Ecology, and the Environmental Protection Agency (and amended in May 1991 and January 1994). This agreement established enforceable milestones to keep the remediation program at Hanford on schedule through the year 2024 .

In 1994, nearly half ( 46 percent) of the entire Hanford Site was remediated, achieving the Secretary's March 1993 commitment to Washington State Governor Lowry. Following regulatory approval of the final condition of these remediated areas, the land in the Arid Land Ecology Reserve and North Slope areas will be available for other uses. The Hanford Site continued to focus on tank safety by completing testing of the mixing pump in Tank 101-SY and implementing new strategies for tank waste remediation outlined in the revised Tri-Party Agreement. In other areas onsite, accelerated ground-water trearment and control projects were initiated, including remediation of contaminated sites near the Columbia River. Significant progress was made toward the resolution of safery concerns relating to the spent nuclear fuel located at Hanford. Alternatives for safe storage of the spent nuclear fuel at the K-Basins in both dry and wet conditions were 
evaluated, and additional studies were done to ensure the safety and health of workers and the environment.

Hanford continued the deactivation of obsolete facilities. The Department decided to shut down the Fast Flux Test Facility where nuclear fuel was once developed to operate at high temperatures using liquid sodium as a coolant. On May 25, 1994, Hanford opened its new low-level decontamination facility. The facility has processed over 450 drums and 58 burial boxes of radioactive and hazardous solid waste since opening. In June, the Secretary hosted Hanford Summit II, the second meering held with Governor Lowry and stakeholders to address balanced long-term environmental remediation and economic growth

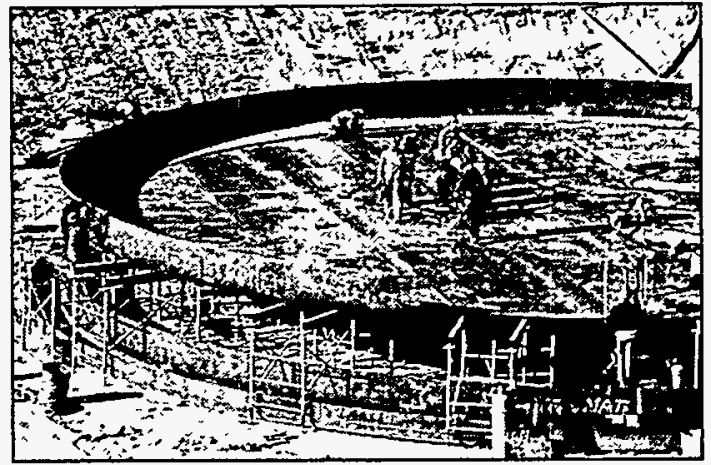

High-level liquid radioactive waste is being transferred to new double-shell tanks at the Hanford Site.

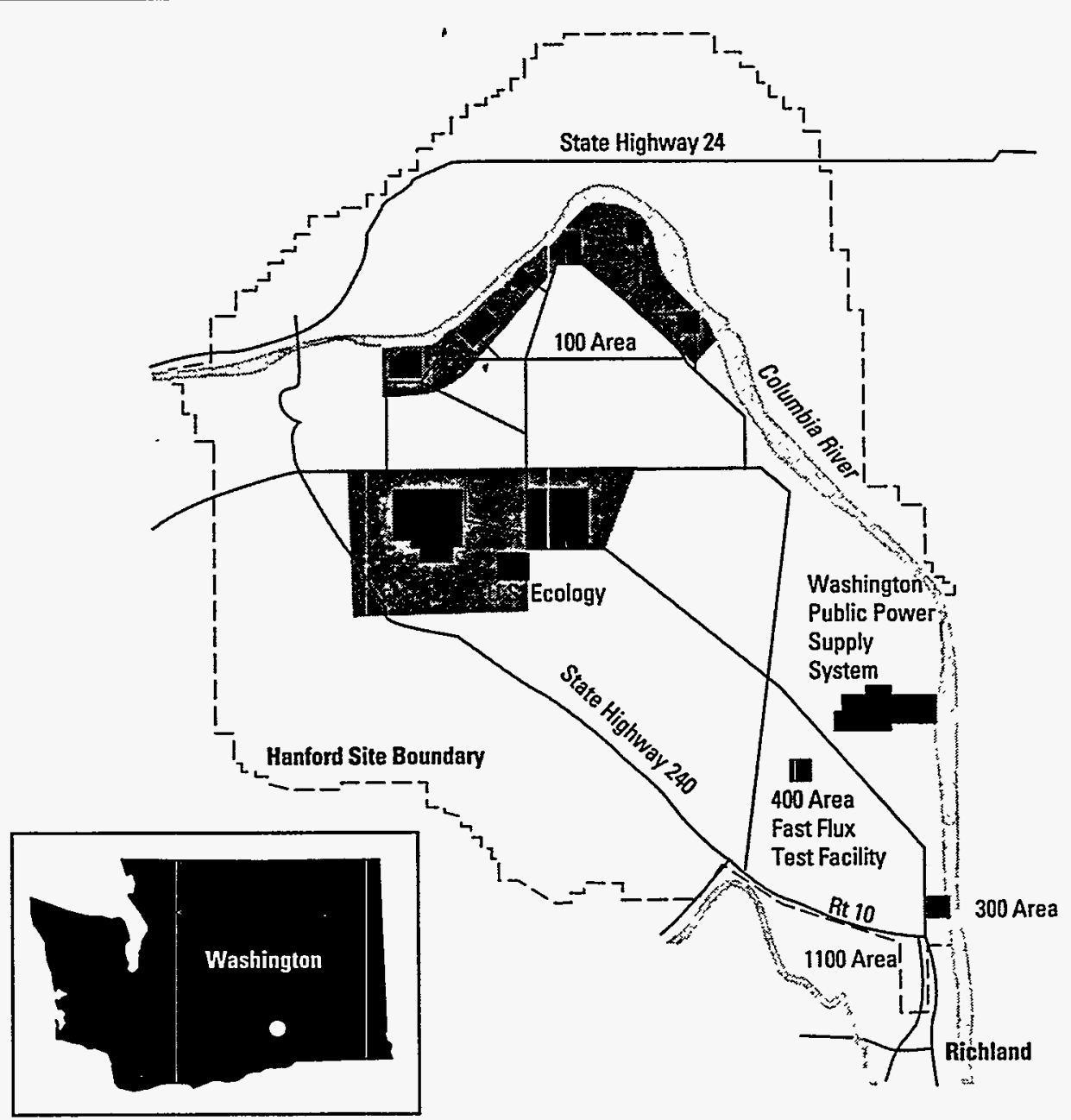

Figure 1. The Hanford Site. 
at Hanford. Stakeholders at the Summir gave the Department both praise and criticism for its performance in cleaning up the Hanford Site and dealing with the public's concerns.

Testing of new technologies to refine the highlevel waste vitrification process began in 1994 and will continue in 1995. Additional technologies were evaluated for rerrieving waste from the singleshell tanks and converting it to more stable waste form.

Biotechnology development efforts at the Hanford Site are underway to treat the waste problems unique to Hanford and other arid sites. This project addresses both vadose zone and ground-water contamination from volatile organic compounds, such as carbon tetrachloride. One key technology under development is in situ bioremediation, where methods to promote microbe breakdown of contaminants are being enhanced.

The Heavy Weight Cone Penetrometer, which is mounted on a truck, penetrates the ground to produce real-time data when used with orher instruments. The Penetrometer, used at Fairchild Air Force Base, generates no waste and has been commercialized. Resonant Sonic Drilling, an innovative technique developed to access soils that are difficult to drill through, is being used to facilitate sampling and remediation. This technique drills at a rate $2-3$ times faster than conventional drill systems and is now commercially available.

- Electric Resistivity Tomography was implemented at Hanford to measure electrical resistance in the soil. The technology, originally developed to monitor environmental remediation operations and provide a three-dimensional image of contaminant plumes below the ground, continues to be developed for new uses such as detection of contaminants in single-shell tanks. A Cooperative Research and Development Agreement, or CRADA, was signed with RIMTech, Inc. in August 1994.

Another new rechnology, Six Phase Soil Heating, developed the ability to split conventional three-phase electricity into six separate phases. This hastens the volatilization of the contaminants, which are removed from the soil via a vacuum. In demonstrations, this technology has removed more than 99 percent of volatile organic compounds from sand, silt, and clay. The process is now being parented.
Environmental management activities at Hanford account for nearly $\$ 1.4$ billion, or 25 percent of the total Environmental Management budget for 1995. This appropriation is only 3 percent more than the budget for 1994 and will include activities to support the recently signed revisions to the Tri-Party Agreement, recently added Defense Nuclear Safery Board commitments, and ongoing Secretarial Safery Initiarives. Planned activities for 1995 include beginning pumping and interim stabilization of four single-shell tanks, completion of an additional 15 Secretarial Safery Initiatives designed to streamline tank waste remediation, the sampling and analysis of the "watch list" tanks, continuing deactivation of the former plutonium-uranium extraction facility, and the transfer of spent nuclear fuel from $\mathrm{K}$-west to the laboratory for characterization.

Hanford will also test several methods to measure contents of radioactive waste in the tanks. Treatment and disposal facilities are scheduled to begin operating in 1995 for some liquid effluent streams in two areas onsite. This will end the discharging of untreated liquids into the ground. Interim actions to reduce dose exposure and risk to both workers and the public will continue, pending the Record of Decision for final disposition of material in the Plutonium Finishing Plant. Hanford will continue to ensure that everything done at the site is competitive with the best commercial practices and adds value to the Department's mission.

In 1996, Hanford will implement a new environmental restoration straregy to accelerate remediation of ground water at areas along the Columbia River. Construction of a Waste Receiving and Packaging Module required to sort and repackage waste that is planned for retrievable storage units will be completed in 1996. In addition, the Environmental Restoration Disposal Facility will be available to receive remediated waste in 1996. Hanford plans to continue work on the Hazardous Material Management and Energy Response Emergency Management Training Center for completion in 1997.
Hanford Has Identified Four

Areas to Measure Its Performance in 1995:

- Reduce risks associated with Waste Management activities.

- Complete 13 characterizations and assessments, 17 interim actions, and 1 final decontamination and decommissioning activity.

- Achieve and maintain safe and environmentally compliant storage, treatment, and disposal.

- Make significant progress toward increasing treatment and disposal capability across the Department of Energy complex, including minimizing waste generated. 
Idaho National Engineering Laboratory Pefformance in 1994:

Idaho was less than one percent over budget and nine percent behind schedule in 1994. Idaho maintained the lowest number of Safety and Health incidents for the last quarter of 1994.

Surveillance and maintenance costs at Idaho were reduced by $\$ 2.7$ million. In September, a new contract structure, which provides incentives to contractors to improve efficiency and effectiveness, replaced the traditional Management and Operating contracts.

\section{Idaho National Engineering Laboratory, Idaho}

The Idaho National Engineering Laboratory (the Laboratory) is located in southeastern Idaho along the western edge of the Eastern Snake River Plain and encompasses a semi-arid area of approximately 890 square miles. The Laboratory is a multipurpose Department of Energy national laboratory providing primarily engineering expertise and operations and development support in the areas of spent nuclear fuel, waste management, environmental assessment and remediation, decommissioning and decontamination of surplus facilities, alternative energy source development, and technology transfer to government agencies and private industry. During 1994, an Environmental Management budget of $\$ 530$ million supported a variety of important waste management, environmental remediation, and technology development activities.
The Programmatic National Spent Fuel Management and the Laboratory's Environmental Restoration and Waste Management Program Environmental Impact Statement was issued for public comment on June 30,1994 . The document is in two parts. The first part analyzes options for responsibly managing spent nuclear fuel nationwide, and the second part covers environmental restoration, waste shipment receipt and storage, disposal and treatment activities at the site. At the Idaho Chemical Processing Plant, the Laboratory investigated treatment alternatives for the site's high-level calcine waste and, in anticipation of eventual decommissioning of the Laboratory's fuel reprocessing facilities, transferred 189 spent nuclear fuel elements into a more modern fuel storage area. A variety of modifications to the New Waste Calcine Facility were initiated to restart the facility in 1996.

One hundred research and development projects were executed in 1994, and four of these technologies were selected for demonstration by the Western Governors' Association. The Rapid Geophysical Surveyor can perform geophysical

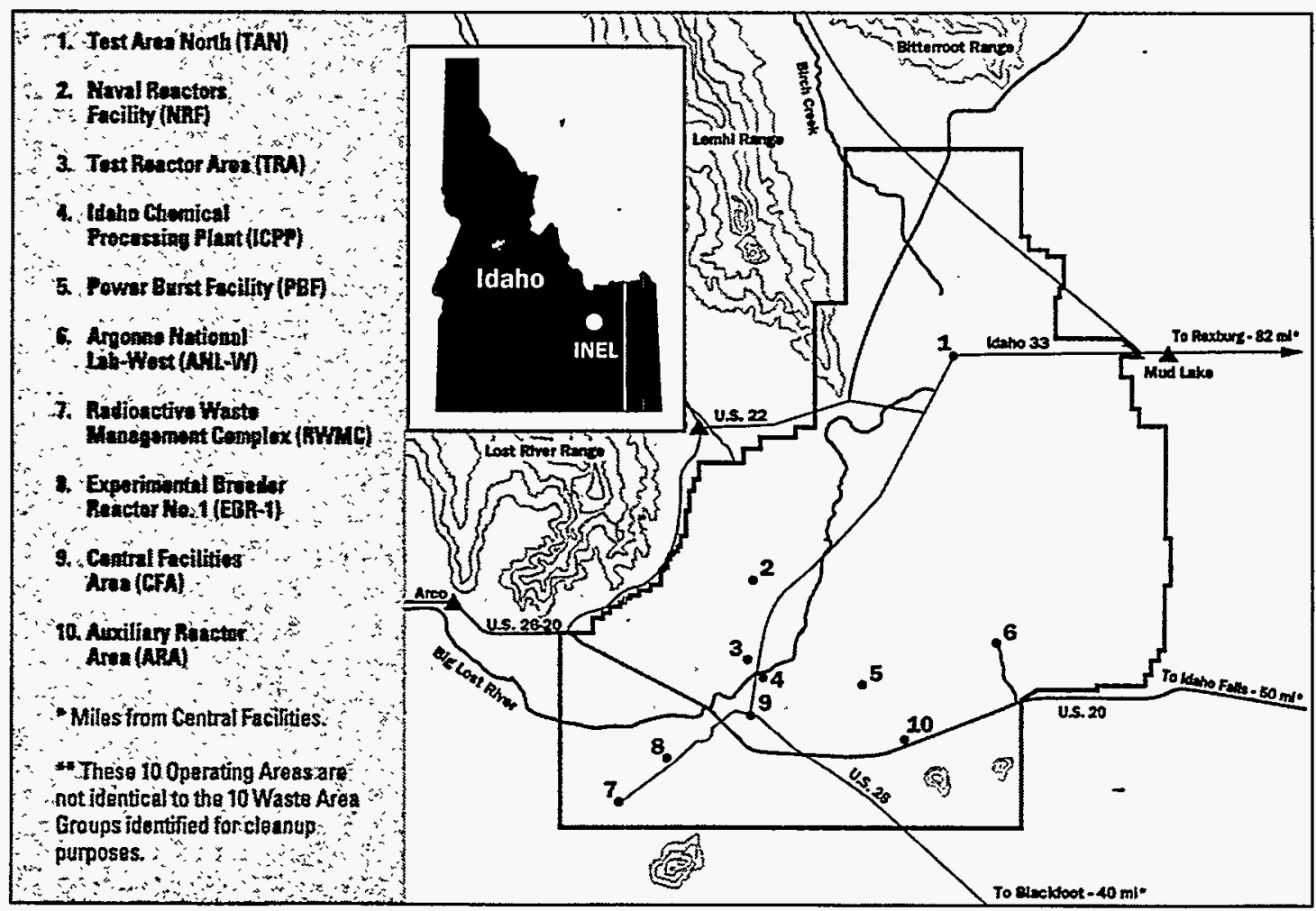

Figure 2. Map of the Idaho National Engineering Laboratory Site. 
magneric surveys quicker and more economically than conventional, hand-held instruments. It can be used at any site to detect metallic buried objects. This technology was licensed to a privare company. The Rapid Transuranic Monitoring Unit, a patented technology, provides on-line monitoring of air and soil contaminated with penetrating radionuclides. The field-deployable unit can analyze and process a variety of samples quickly and cost effectively. The Plasma Hearth Process destroys organic materials and melts metals and inorganic materials in a one-step process. Utilizing this technology reduces the amount of pretreatment or characterization necessary. The Contamination Control Unit efficiently suppresses contaminared dust utilizing a variery of non-hazardous technologies to control dust and windblown contamination while excavating buried waste.

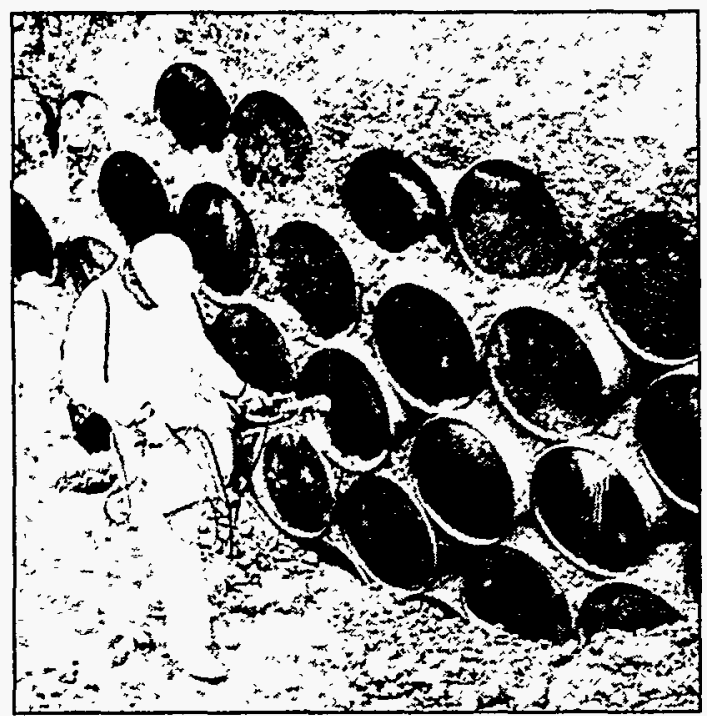

A worker at the Radioactive Waste Management Complex checks buried low-level waste for leakage.

At the Radioactive Waste Management Complex, above-ground containerized transuranic waste was transferred into RCRA-approved storage modules. The safery analysis report for the Waste Experimental Reduction Facility operations, including the incinerator, was approved. The proofof-process was successfully tested at Pit 9 , and a contract to perform remediation was signed. The successful implementation of this process at Pit 9 could significantly alter remediation strategies nationwide. The Laboratory also began site-wide assessments and decontamination and decommissioning of surplus facilities.

The Idaho National Engineering Laboratory successfully moved beyond the assessment phase and into remediation of the installation's contaminated areas. In 1994, the Laboratory crossed an important marker in the program by spending more funds on remediation than assessment. This trend will continue in future budget planning with even more funds devoted to remediation. This measurable success has been due to the implementation of the Federal Facility Agreement and Consent Order negotiated by the Department with Environmental Protection Agency Region $X$ and the Stare of Idaho. Innovations in site characterization and reporting, and a good working relationship with regulating agencies have also directly contribured to the sire's progress. Since the signing of the Agreement and Consenr Order in December 1991, no milestones have been missed, 10 Records of Decision have been signed, 6 interim actions are in progress or complete, and No Further Action decisions have been approved for 104 potential release sites.

The five prime management and operating . contracts at the Laboratory were consolidated into a new organization under one contract, providing an estimated savings of $\$ 742$ million over a 5-year period. About two-thirds of this savings will be applied to environmental management programs.

In 1995 , with a budget of $\$ 532$ million, planned activities include continuation of environmental remediation work to comply with Federal Facility Agreement/Consent Order, construction of new retrieval and waste characterization facilities at the Radioactive Waste Management Complex, issuance of the Record of Decision for the site's programmatic spent nuclear fuel and sire-wide environmental impact starement, and construction of the remediation facility at the Pit 9 site. In addition, testing of treatment technologies for calcine- and sodium-bearing liquid high-level waste, finalization of the Consent Order Agreement with the State of Idaho for waste treatment, and issuance of the final Site Treatment Plan are planned. Research and development efforts will continue for buried waste retrieval and waste characterization, and technical support will continue for the Waste Isolation Pilot Plant. Enhancements are planned for the Waste
The Environmental Management Site Specific Advisory Board-Idaho National Engineering Laboratory was formed in March 1994 after a lengthy design and selection process. The Board will provide input and recommendations on a wide range of environmental management decisions that impact future use, risk management, economic development, and budget prioritization activities. While its focus remains on site-specific issues, the Board will have the opportunity to make recommendations to national Department of Energy policymakers at Headquarters.

What is at Pit 9?

Pit 9 is an inactive disposal pit approximately one acre in size. Nearly 110,000 cubic meters of waste, such as containerized sludge containing plutonium, was generated by Rocky Flats in the late 1950's. 
Idaho Has Identified Four Areas to Measure Its Performance in 1995:

- Conduct eight assessments, three interim actions, one final remediation, and two final decontamination and decommissioning activities.

- Reduce the 1994 goals by more than 19 percent of waste generated during ongoing operations at the Idaho Chemical Processing Plant.

- Complete all scheduled transfers of spent nuclear fuel at the Idaho Chemical Processing Plant.

-Increase the number of facilities deactivated.
Experimental Reduction Facility, fuel transfers will continue at the Idaho Chemical Processing Plant, and evaporation activities are planned to be complete to reduce the volume of high-level liquid waste to be treated at the New Waste Calcine Facility. Aggressive efforts will continue to develop partnerships with private industry and universities.

In 1996 , with an anticipated budget of $\$ 481$ million, planned activities include the restart of Waste Experimental Reduction Facility and the New Waste Calcine Facility. Fifty percent of the transuranic waste in the Radioactive Waste Management Complex buildings will be transferred into RCRA-approved storage modules.

Construction of the remediation facility at the Pit 9 site and the retrieval enclosures facility at the Radioactive Waste Management Complex are also planned for completion. Other planned activities include assessment and disposal of surplus facilities throughout the site, fuel transfers at the Chemical Processing Plant, environmental remediation in compliance with Federal Facility Agreement and Consent Order schedules, and start of construction of the waste characterization facility at the Radioactive Waste Management Complex.

\section{Alaska}

Amchitka Island is the only site in Alaska where Environmental Management is currently conducting work. The site was used for nuclear weapons testing and other experiments between 1961 and 1971. Contaminated soil was moved to the Nevada Test Site. Long-term hydrological monitoring is continuing on the island, pending commencement of assessment activities. Remediation, disposal, and public meetings at the Project Chariot site were completed in 1994.

\section{Galifornia}

The Department is currently conducting environmental management activities ac 11 sites in California. The University of California at Berkeley is a FUSRAP site and is cited on page 24.
General Atomics is a privately owned and operated nuclear facility located near San Diego, California. It maintained and operated a hot cell facility for over 30 years, primarily to conduct government-funded nuclear research and development. The hot cells were used to perform examinations on irradiated fuels, structural materials, instrumentation, and dosimerry. Declining use and encroaching development in the surrounding research parks led to the decision to decontaminate and decommission the hot cell facility. During 1994, and with an Environmental Management budget of $\$ 3.0$ million, General Atomics initiated activities to dispose of irradiated fuel materials, initiated characterization activities, and porepared Narional Environmental Policy Act documentation for proposed decontamination and decommissioning activities and transfer of irradiated fuel materials to another Department site for interim storage. During 1995, with a budget of $\$ 2.7$ million, General Atomics will commence decontamination and decommissioning activities that will continue through 2000 .

The General Electric Vallecitos Nuclear Center is a privately owned research facility located in Pleasanton, California. From 1962 through 1979, the site was used for uranium and mixed oxide fuel fabrication and development. While the cell funded by the Department is no longer used, the remainder of the facility is active. General Electric plans to decontaminate the cell, which the Department had operated to examine uranium fuel and reactor components after irradiation. The cell was later converted to study mixed oxide fuel cell rods. General Electric will also decontaminate and dispose of a glove box operation that was installed by the Center in 1968 for analysis of mixed oxide fuel for the Department. Preparation for decontamination and decommissioning activities will begin in 1997 and is scheduled to be complete after the year 2000 . The budget for 1995 is $\$ 360,000$, and $\$ 105,000$ is requested in 1996 for continued surveillance and maintenance and preliminary characterization.

The Laboratory for Energy-Related Health Research is located at the University of California, Davis. Research at the Laboratory originally focused on the health effects from chronic exposures to radionuclides - primarily strontium ${ }^{90}$ and radium ${ }^{226}$ - using animal subjects to simulate radiation effects on humans. In 1988, the 
Department terminated the research program and closed the Laboratory. The present mission is confined to decontamination and decommissioning, site remediation, and related activities for eventual release of the facilities and site to the University for unrestricted use.

During 1994, with a budget of $\$ 6.5$ million, the Laboratory continued decontamination and decommissioning of the Imhoff facility and tank trailer were completed. A CERCLA site-wide remedial investigation of the soil and ground-water contamination was initiated. The facility was placed on the National Priorities List in May 1994. Activities scheduled for 1995 include completion of decontamination and decommissioning program and continued investigations of soil and groundwater contamination. The Laboratory will also continue waste management activities, including inspection, maintenance, and labeling waste onsite. The 1995 budget is $\$ 4.0$ million. In 1996 , with a budget request of $\$ 4.7$ million, work will continue on the CERCLA site-wide remedial investigations of the soil and ground water.

The Lawrence Berkeley Laboratory, adjacent to the University of California, Berkeley, conducts a wide variety of energy-related research activities for the Department, including energy, environment, physics, transportation, computers and communication, biology, and medicine. Past practices have left radioactive and hazardous contaminants in the soil and ground water.

The 1994 Environmental Management budget at the Laboratory was $\$ 19.1$ million. Activities included offsite disposal of RCRA/Toxic Substances Control Act waste, low-level waste, and mixed waste, as well as the construction of a new Hazardous Waste Handling Facility. This facility will allow the site to consolidate and relocate existing waste-handling operations into one central facility. It will also provide improved safety containment features that will further reduce the risk of an accidental release of hazardous waste. In 1994, the site completed investigations of various solid wasie management units; continued implementation of interim corrective measures, including treatment of over 800,000 gallons of contaminated ground water; and initiated a tritium risk assessment. Two factsheets describing sire activities were distributed to stakeholders.
Lawrence Berkeley Laboratory currently conducts research to develop technologies to address a number of local and national environmental problems. The Laboratory is a leader in the development of barrier technology, designed to isolate waste below the surface using new materials developed in collaboration with private industry. The Laboratory is also developing a cryogenic drilling process of horizontal boreholes in sediments. The Environmental Management budget for the Laboratory is $\$ 15.9$ million for 1995 and $\$ 12.5$ million for 1996 .

The Lawrence Livermore National Laboratory occupies two sites in northern California. The Main Site has an area of approximately 1 square mile and is located 40 miles east of San Francisco, just east of the City of Livermore. Site 300, which comprises approximately 11 square miles, is located 15 miles southeast of the Main Site. At the Main Site, U.S. Navy operations in the 1940's and subsequent laboratory activities involving the handling and storage of hazardous materials resulted in the release and offsite migration of contaminants in soil and ground water. Operations at Site 300 involved the processing, testing, and deactivation of explosives, which contaminated both soil and ground water at the site. Both sites have wastewater, petroleum tank systems, and transformers that must be upgraded to meet local, State, and Federal requirements. The 1995 Environmental Management budget for both Lawrence Livermore sites is $\$ 76.2$ million.

The Department's Oakland Office, Laboratory personnel, and regulators negotiated the priorities of all the tasks associated with the remedial actions for the Livermore Site. Negotiation for the Main Site resulted in an agreement to focus on three areas of priority: the western plume capture, the southern plume capture, and internal source control/mass removal. The new schedule is reflected in an amendment to the Remedial Action Implementation Plan.

During 1994, Treatment Facility C began operation in October 1993, which was the fourth treatment facility onsite. At the end of June 1994, the four facilities had pumped nearly 19.3 million gallons of ground water and removed 6.8 kilograms of volatile organic compounds. In addition, Treatment Facility $F$ treated 6 million gallons of ground water and 11.2 million cubic feet of extracted vapor to remove 1,125 gallons of
The Environmental Protection Agency's National Priorities List is composed of sites that must be cleaned up quickly to protect people and the environment. The Environmental Protection Agency is required to designate substances as hazardous, and owners and operators of hazardous waste sites must report to the Environmental Protection Agency what substances they have and if there is any known, suspected, or likely releases of these substances to the environment. 


\begin{tabular}{l}
\hline \hline A Feasibility Study is an \\
analysis of the \\
practicability of a proposal \\
such as a description and \\
analysis of the potential \\
cleanup alternatives for a \\
site. The feasibility study \\
emphasizes data analysis \\
and usually recommends \\
selection of a cost- \\
effective alternative. It is \\
usually performed with and \\
uses data from a remedial \\
investigation; together, \\
they are commonly \\
referred to as a "Remedial \\
Investigation/Feasibility \\
Studies" or remedial \\
investigation/feasibility \\
study. The term can apply \\
to a variety of proposed \\
corrective or regulatory \\
actions. \\
\hline \hline
\end{tabular}

gasoline. A treatability study at the Trailer 5475 area, where ground water has been contaminated by both volatile organic compounds and tritium, was completed. The remedial investigation of Building 518 was completed, and the Final Remedial Design Report No. 3 on Building 518 Vapor Extraction Treatability Study results was issued. The Arroyo pipeline and the Detailed Study Area Pipeline for Treatment Facility A area were completed in 1994. Design and construction of Treatment Facility D was completed, and operations began in 1994.

Technology Development and Environmental Restoration jointly funded research on a unique technology - dynamic underground stripping - to rapidly remove some 29,000 liters of gasoline from an underground plume at this treatment facility. This technology applies heat, by steam and electricity, to vaporize trapped contaminants in the soil. Once vaporized, the contaminants are, removed by vapor extraction. Dynamic underground stripping is an economically feasible technology for a range of contaminant problems and promises to be the remediation technology of choice at numerous sites in the future.

Bioremediation technologies are also being researched and developed at Livermore.

Department of Energy researchers, using funds from the National Aeronautics and Space Administration, have developed an in situ microbial filter. The filter is made up of microorganisms that breakdown contaminants found in waste streams at the site when ground water passes through the filter. A full demonstration of the filter will take place in 1995.

With a 1995 Waste Management budget of approximately $\$ 44$ million, the Laboratory plans to continue to treat and dispose of approximately 3,000 cubic yards of waste; complete preliminary engineering designs for its two projects, the Decontamination and Waste Treatment facility and the Mixed Waste Management Facility; and develop the Final Site Treatment Plan for the trearment of the mixed waste generated by the Laboratory. The proposed Mixed Waste Treatment Facility will provide a test bed to demonstrate integrated systems to treat mixed waste, primarily focusing on developing alternatives to incineration. Livermore also plans to develop a "cradle-to-grave" database to track the storage, disposal, and processing of waste from its creation until its permanent disposal.

In 1995, the Laboratory is expected to issue a Final Remedial Design Reporr No. 6 for the vapor treatment facility and Final Remedial Design Report No.5 for Treatment Facility G. A draft compliance monitoring plan will be submitted to regulatory agencies. The vapor treatment facility is scheduled to begin operating in September 1995.

At Lawrence Livermore National Laboratory Site 300 , several enforceable regulatory milestone document deliverables were met in 1994. A Site Wide Remedial Investigation Report, four characterization plans, a Draft and Final Feasibility Study for Operable Unit 2/ Building 834, and a Draft Feasibility Study for Operable Unit 3/ Pit 6 were all prepared and provided to the regulators for review, comment, and approval. Ar Building 834, trichloroethylene spills and leaks have resulted in high concentrations of the chemical in soil and ground water. The Laboratory is currently evaluating a number of remedial alternatives. Based on the minimal potential for offsite exposure and the likely presence of Dense Non-Aqueous Phase of Liquids, the Laboratory expects to complete an interim Record of Decision on the building that will allow testing of the microbe filter.

Pit 6 is a closed landfill that may have leaked small quantities of trichloroethylene into local ground water. After evaluating a variety of remedial action alternatives, the Laboratory has proposed covering the landfill to contain any additional leaks and allowing the contaminant to degrade naturally. In addition, the Laboratory will complete five draft feasibility studies and one proposed plan for Site 300. The Department and the Laboratory will expedite the remediation process to decrease the administrative burden on the project. In 1995, Lawrence Livermore expects to complete an interim Record of Decision on the Building 834 operable unit that will allow for testing of innovative technologies to cope with Dense NonAqueous Phase of Liquids contamination.

With a 1996 Environmental Management budget request of $\$ 77.9$ million, Livermore plans to begin the treatment and disposal of its mixed waste as described in the Sire Treatment Plan proposed in accordance with the Federal Facility Compliance Act. Final engineering design will be completed for the Mixed Waste Management 
Facility. In addition, the Laboratory will continue its waste minimization initiatives to reduce the amount of waste generated.

The Oxnard Facility, operated by EG\&G Rocky Flats, has produced nonnuclear forgings for the weapons program since 1981 . Because this specialized capability will no longer be needed after 1995 , the facility will be returned to the private sector for economic development. The Grand Junction Projects Office has assumed responsibility for remediation activities. An Environmental Site Assessment was conducted in 1994 to review the history of the site and determine areas of concern. Planned activities in 1995 include characterization of soils, structures, and ground water, and preparation of a physical assessment. Remediation of any contamination found during the characterization is scheduled for 1997.

The Salton Sea Base in Imperial County was formerly used by Sandia Narional Laboratories and currently is owned and operated by the U.S. Navy. Previous Sandia operations may have contributed to the environmental problems at the site. Also, in 1972, the Energy Research and Development Administration, the Department's predecessor, agreed to jointly fund, with New Albion Resources Company, an experimental geothermal power test plant on 20 miles of land in the Salton Sea area. The Department expects potential payour for Salton Sea to be offset by expenses associated with Department of Energy cleanup for Department of Defense sites.

Environmental Restoration activities continue at the Sandia Livermore facility adjacent to the Lawrence Livermore Narional Laboratory. The facility occupies an area of approximately 100 acres and has an 1995 Environmental Management budger of abour $\$ 8.3$ million.

The Santa Susana Field Laboratory is a 2,700-acre site owned and operated by Rockwell International, of which approximately 90 acres are furnished without charge to the Department of Energy for the Energy Technology Engineering Center. The Center has provided management, engineering, and project oversight on a wide range of programs involving the testing of nonradioactive components. These programs were significantly curtailed at the end of 1993.

The Atomics International division of Rockwell began nuclear research utilizing small low-powered reactors in the northwest portion of the Santa
Susana Field Laboratory in 1956. Environmental restoration and decontamination and decommissioning activities began in the early 1970 's. Today, activities at four facilities remain to be completed. At the reactor test facility, radioactive contaminated materials have been removed, and final cleanup criteria and surveys will be conducted to ensure remediation is complete. Independent verification of the facility will be completed in 1995. At the former sodium disposal facility, all contaminated material has been removed. The site is waiting for final sampling to verify cleanliness for State regulatory acceptance. Remediation at the radioactive materials disposal facility is scheduled to begin in mid 1995.

Other planned activities include remediation of ground water contaminated by volatile organic compounds. In 1996, surplus test facilities will be transferred to the Environmental Management program for ultimate disposition. Surveys of areas not previously assessed will be completed in 1996 to ensure that no remaining areas of contamination exist. Total 1995 funding will be $\$ 10.0$ million, and 1996 funding is projected at $\$ 7.0$ million.

The Stanford Linear Accelerator Center, managed under contract between the Department and . Stanford University, conducts theoretical research in high energy particle physics. Due to routine maintenance operations associated with the accelerator, certain hazardous waste streams have developed including waste oils, waste solvents, polychlorinated-biphenyl-contaminated oils, aqueous metals, and wastewater treatment sludge. This waste is temporarily stored onsite until it is shipped to permitted offsite disposal facilities within 90 days of being generated. The Center also stores low-level radioactive waste until it is shipped to the Department's Hanford site in Washington.

During 1994, the Center continued to properly dispose of hazardous and radioactive waste, minimize waste generation, and commence its investigation of contaminated soil and ground water. Design for the Radioactive Management Waste Storage Facility being built onsite was approved in 1994, and required National Environmental Policy Act documentation was completed. A Safety Analysis Report on the facility was also conducted and submitted. The 1995 Environmental Management budget for the site is $\$ 6.4$ million, with which the site plans to commence characterization activities of 
contamination from past activities and manage hazardous and radioactive waste generated from current operations. The Center's Environmental Management budget request for 1996 is $\$ 5.0$ million.

\section{Hawaii}

2.

During 1994, sampling was conducted at the former Kauai Test Facility. Based on these samples, Sandia National Laboratory in New Mexico, which manages the site, plans to submit a request to Environmental Protection Agency Region X for approval of a No Further Action decision.

\section{Idaho}

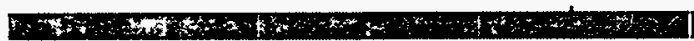

Argonne National Laboratory-West is located on the southeastern portion of the Idaho National Engineering Laboratory. This site has three experimental nuclear reactor operations performing research and development. The primary environmental management activities are managing waste streams, upgrading waste management facilities, remediating waste sites within the area, and supporting Waste Isolation Pilor Plant related activities.

In 1994, with an Environmental Management budget of $\$ 4.2$ million, activities included installing 145 double-lined waste storage containers, 12 corrosion tubes, and 10 surveillance liners. A radioactive liquid transfer line was replaced, and two new monitoring wells to mitigate risks were constructed.

In 1995 , with a budget of $\$ 4.7$ million, plans include installing 100 additional double-lined waste storage containers, transferring low-level waste into new waste storage liners, and completing an investigation and feasibility study to define the scope of remediation work required for the area. In 1996 , with an anticipated budget of $\$ 5.6$ million, planned activities include installation of a monitoring well and continuing transfers between waste liners.

\section{Montana}

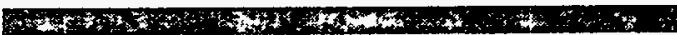

In April 1994, the Department of Energy announced its plan to transfer management of its Components Development and Integration Facility in Butre, Montana, from the Office of Fossil Energy to the Office of Environmental Management. When the facility transferred to Environmental Management in 1995, it became the Western Environmental Technology Office. This site will continue developing environmental technologies and commercialization activities, emphasizing mine remediation, waste treatment, resource recovery, and water resource management. Because the site has no record of radioactive marerial usage and no history of environmental contamination, the facility can focus on serving as a national resource for developing new and innovative environmental technologies.

The Butte facility is unique because most of its projects are sponsored by numerous Federal agencies. The Department has teamed with the Environmental Protection Agency and the Departments of Defense, Interior, and Agriculture to foster cooperative research and data sharing, resulting in rapid transfer of new technologies to confront some of the Nation's most urgent environmental remediation issues.

\section{FUSRAP AND UMTRA Sites}

The two FUSRAP sites in the Northwestern region are the Albany Metallurgical Research Center near Albany, Oregon, and a research laboratory at the University of California at Berkeley. Environmental management activities at these sites were completed in 1991 and 1982, respectively.

There are seven UMTRA sites in the Northwestern region. At six of the UMTRA sites in this region, there is evidence of residual groundwater contamination. No one is currently using the water at any of these locations. A draft Programmatic Environmental Impact Statement addressing ground-water contamination at all of these sites will be released soon. This document discusses proposed acrions and alternatives. The Department will hold interactive meetings to discuss this document in early 1995. Ground water 
is monitored at these sites to observe changes before, during, and after surface remediation action, and as part of the UMTRA Ground Water Project Baseline Risk Assessment being conducted at the Riverton, Spook, and Lakeview sites. When these assessments are complete, the Department will meet with local citizens and government officials to discuss the results of the initial analysis. Further actions will be taken as necessary to comply with ground-water standards established by the Environmental Protection Agency.

At the Edgemont Vicinity Properties near Edgemont, South Dakota, surface remediation was completed prior to 1994.

The Belfield sire, managed under the UMTRA project, is located in southwestern North Dakota, one mile sourheast of the Town of Belfield in Stark County. Between 1964 and 1966,60 tons of lignite ash were produced each day. This ash was shipped to Rifle, Colorado, for further processing. In June 1994, all activities associated with developing environmental documentation and remedial action plans were placed on hold. At that rime, the State of North Dakota indicated verbally that they did not plan to provide the State's 10 percent share of remediation costs. The current plan is to complete the environmental documentation and remedial action plan in 1995. Remedial action is scheduled to commence in 1996 and be completed in 1997.
The Bowman site is locared in southwestern North Dakota approximately seven miles west of Bowman, North Dakota. The site conducted ashing operations from 1963-1967. Like the Belfield site, all activities associated with developing environmental documentation and remedial action plans were placed on hold at Bowman in June 1994. At thar time, the State of North Dakota indicated that they did not plan to provide the State's 10 percent share of remediation costs. The current plan is to complete the environmental documentation and remedial action plan in 1995. Remedial action is scheduled to commence in 1996 and be completed in 1997.

The Lowman former processing site is located in Boise County, Idaho, approximately 75 miles northeast of Boise in the Boise National Forest. The site covers approximately 37 acres, 5 of which contained mill tailings at 10 different locations. Concrete foundations, other mill debris, and windblown materials were contaminated at this site. Site remediation was completed in October 1991, including all vicinity properties. In 1994, interim surveillance, maintenance, and site certification efforts continued. In September 1994, the site was licensed by the Nuclear Regulatory Commission and will be transferred to the Grand Junction Projects Office for long-term surveillance and monitoring in 1995.

\section{UMTRA INSTALLATIONS/SITES}

Arizona
Monument Valley*
Tuba City*
Colorado
Durango*
Climax*
Gunnison
Maybell
Naturita
Now Rifle
Old North Continent
Old Rifle
Union Carbide
Idaho
Lowman*

New Mexico Ambrosia Lake Shiprock*

North Dakota

Belfield

Bowman

Oregon

Lakeviaw*

Pennsylvania

Canonsburg*

Texas

Utah

FallsCity*

Green River*

Mexican Hat*

Salt Lake City*
Wyoming

Riverton*

Spook*

*completed 
Fee lands, like the Riverton site discussed on page 25 are lands within Indian Reservations that were sold by Native Americans, thereby allowing the lands to be privately owned. This occurred before the laws protecting ownership of Native American lands were enacted.
The Riverton former processing site is locared about 2.4 miles southwest of the center of Riverton in Fremont County, Wyoming. Although not on the Wind River Indian Reservation, the site is completely surrounded by the reservation. The ground-water plume resulting from milling activities has migrated offsite and onto the reservation lands. Surface remediation was completed in November 1989, and site certification activities will be completed in 1995 . This will mark the closeout of all remaining surface activities for the site. Upon certification of the surface remedial action by the Nuclear Regulatory Commission, the site will be sold to an adjacent landowner.

The Spook site, which was the Converse County former processing site and tailings pile, is located approximately 48 milles northeast of Casper, Wyoming. The sire covers about 55 acres. In 1994, site responsibility was transferred to the Grand Junction Projects Office under therlong- term surveillance and monitoring program. Once the work plan for the ground-water project is prepared, public meetings will be held with local citizens and government officials to discuss the initial analysis of the ground-water conditions at the site.

The Lakeview site is located in Lake County, Oregon, approximately 1.5 miles northwest of the Town of Lakeview. The site covers about 258 acres. Site remediation was completed in October 1989, when 926,000 cubic meters of contaminated material was relocated to an offsite disposal site. The sire was certified by the Nuclear Regulatory Commission in Seprember 1993 and received concurrence on the long-term surveillance plan, pending receipt of the title transfer, in September 1994. Interim surveillance monitoring and site licensing activities will continue until the site is transferred to the Grand Junction Projects Office. 


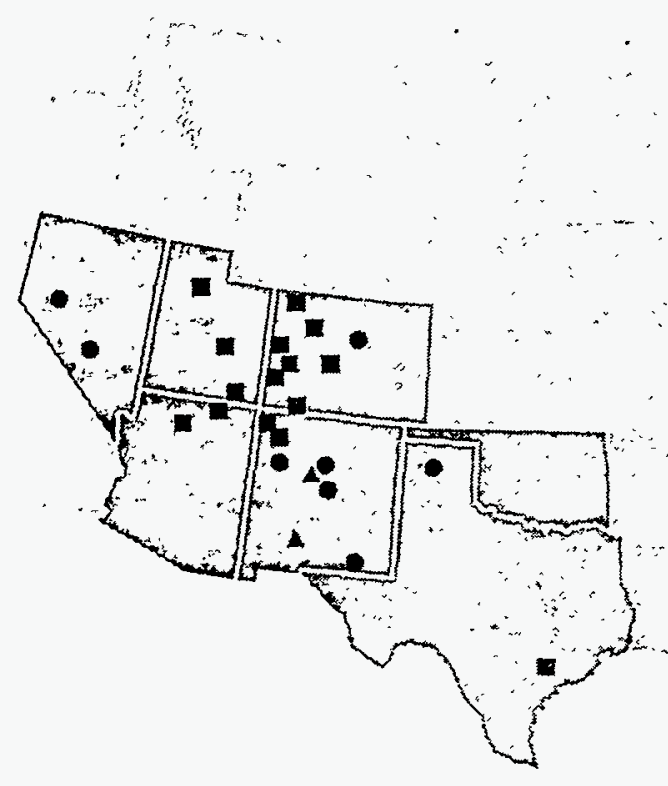

\section{Southwestern Site Summaries}

\section{Rocky Flats 1994}

Performance:

Rocky Flats, as of September 1994, was 11 percent behind schedule and 5 percent under budget. The waste management program at Rocky Flats contributed to these numbers by being 7 percent behind schedule and 8 percent under budget. Environmental restoration is 25 percent behind schedule, 8 percent under budget, and facility transition is 5 percent behind schedule and I percent under budget.
For the purpose of this report, the Southwestern region includes seven States: Arizona, Colorado, Nevada, New Mexico, Oklahoma, Texas, and Utah. The major sites in the region are the Rocky Flats Environmental Technology Site in Colorado, the Nevada Test Site in Nevada, and the Waste Isolation Pilot Plant in New Mexico. The FUSRAP program has completed activities at three sites in the region. The UMTRA project is responsible for 18 sires in this region, nine of which are located in Colorado. Information on these sites begins on page 38. This section includes general budget and performance information. More specific information can be found in the Performance and Funding Data section beginning on page 61.

\section{Rocky Flats, Colorado}

The Rocky Flats Environmental Technology Site is located in northern Jefferson County, approximately 16 miles northwest of Denver. The site is 10.4 square miles, including a buffer zone between the site and its boundaries. With the discontinuation of nuclear weapon components production at Rocky Flats, and the consolidation of the production of nonnuclear weapons components at the Kansas City Plant in Missouri, Rocky Flats' mission now focuses on environmental remediation, nuclear material management, and deactivation and conversion of facilities for alternative uses.

In 1994, with a 1994 Environmental Management budget of $\$ 488.7$ million, Rocky Flats made significant progress stabilizing and consolidating special nuclear material onsite. Rocky Flats completed the first phase of the Liquid Stabilization program, further reducing risk to workers, the public, and the environment.

In 1994, waste treatment, storage, and disposal activities continued, and significant environmental restoration accomplishments were made. Among the major milestones completed was the draining of all pond sludge and water from Solar Pond B South, which reduced the ongoing contamination of ground water. Contaminated sludge from the pond is being stored in tanks until a final disposition is determined. In addition, the first Record of Decision from the Rocky Flats site was signed by the Department, the Environmental Protection Agency, and the State of Colorado. Remedial investigations continue on several remaining inactive sites. Also in 1994, a work plan for accelerating environmental restoration was developed 
Three Areas Rocky Flats

Will Measure its

Performance in 1995:

The Rocky flats 1995

Performance Indicators

project 1 completed

assessment, 4 interim

actions, 1

decontamination and decommissioning activity, and no final remediations. which reflected comments from the public. Under the proposed accelerated program, remediation of nearly all non-industrial areas of Rocky Flats could be achieved by the year 2000, if sufficient funding is made available. Four accelerated remediation projects are already underway, and an additional nine are in planning or design phases. Another significant accomplishment involved packaging and dispositioning of RCRA-regulated excess chemicals from 53 facilities at the site. The removal of chemicals, nuclear material, and classified tooling from facilities is an important first step toward the deactivation and conversion of facilities.

The Department's contract reform effort was initiated at Rocky Flats with plans being formulated to replace the Maintenance and Operating contracting method with an integrated contractor and sub-contractor structure. In concert with this reform effort, the Economic

Development program sponsored Vendors Conference ' 94 and issued a solicitation for new and innovative ideas to accomplish the work to be done at Rocky Flats. It also requested proposals regarding privatization and economic conversion of facilities, human resources, and rechnologies developed at the site. It is anticipated that responses

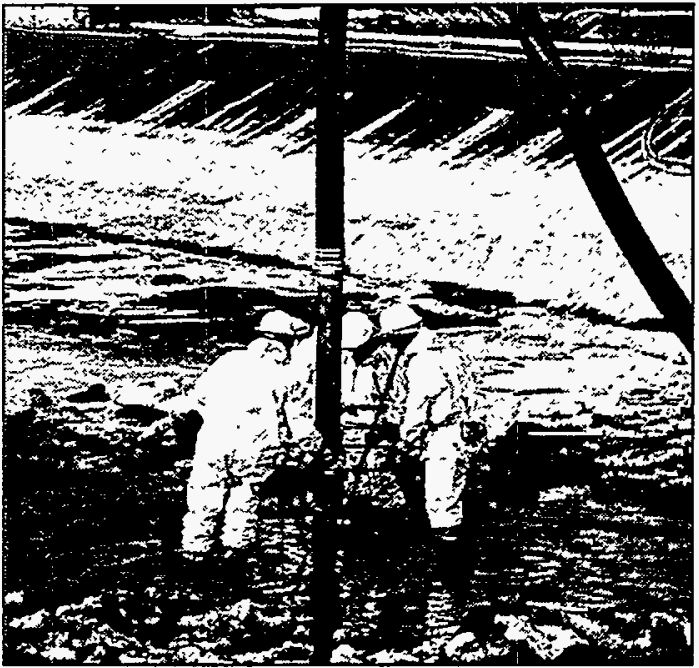

Solar Pond Remediation at Rocky Flats Test site.

to this solicitation will provide new opportunities for existing facilities and the involvement of existing resources in industries that are not dependent upon the defense mission. The formation of a new partnership with the Los Alamos National Laboratory made the additional technical capabilities required to implement the

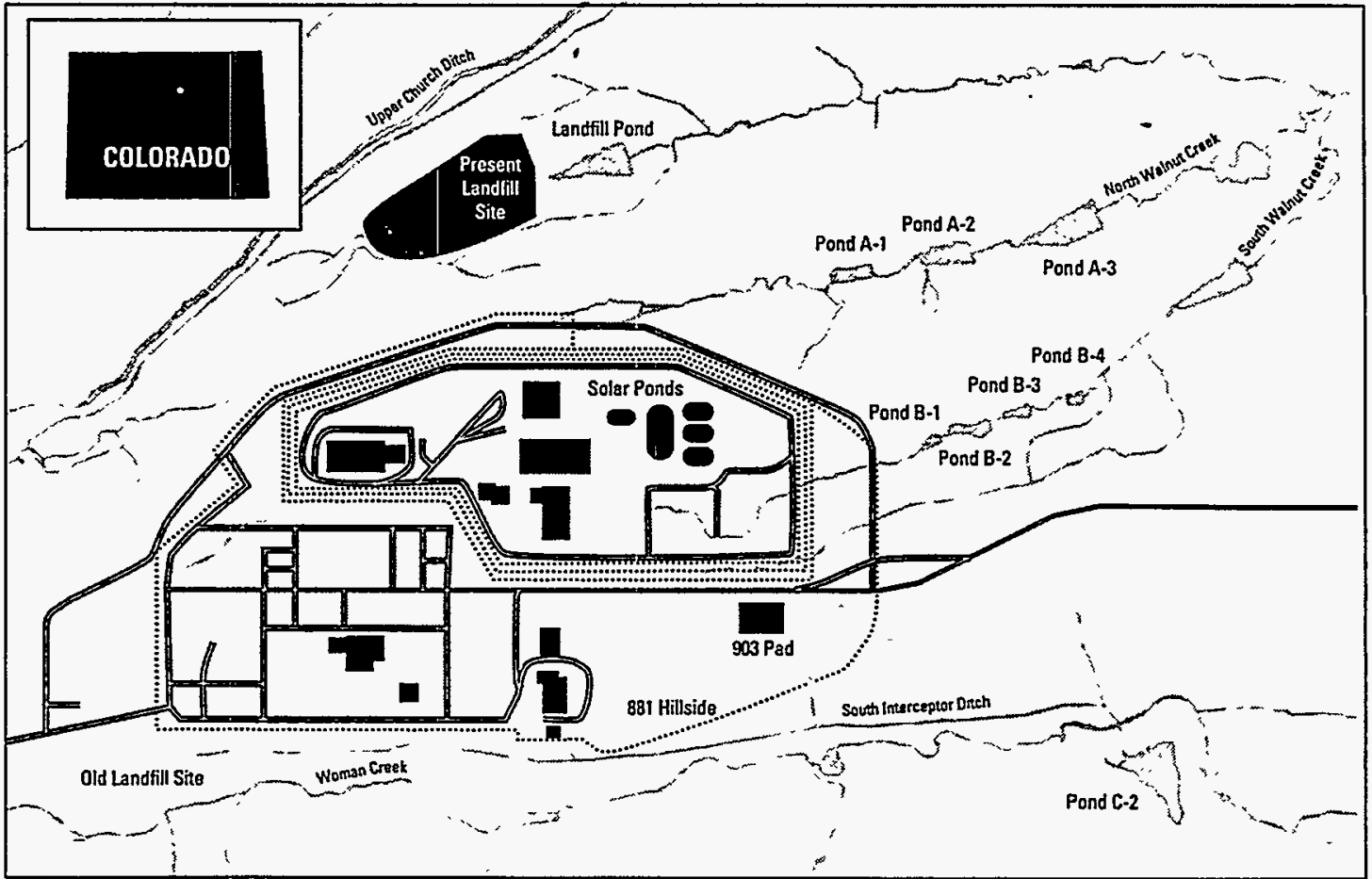

Figure 3. Rocky Flats is located approximately 16 miles northwest of Denver. 
site's goals available. In addition, the Federal Advisory Committee to Develop Onsite Innovative Technologies, or DOIT, established by the Western Governors' Association and four Federal agencies to stimulate the application of cost-effective, innovative technology systems demonstrations, sponsors many innovative waste treatment technology development projects, including Microwave Solidification and Thermal Desorption.

Among other projects this year, with a 1995

Environmental Management budget of $\$ 618.6$ million, two more inactive areas will be dispositioned. One of these areas is an evaporative spray field used to dispose of solar pond water in . past years. It is anticipated that a "no action" remedy will be approved for this spray field, based on existing data. The second area includes the interior of two former nonnuclear production buildings that are prime candidates for commercialization under the National Conversion Pilor Project. Preparations for construction of a closure cap over the solar ponds will begin. The new sanitary landfill at Rocky Flats will be complete in 1995, which will allow the existing landfill to be closed. The sire will submir a Proposed Site Treatment Plan to the State of Colorado and the Environmental Protection Agency as required by the Federal Facility Compliance Act.

Long-range strategic plans developed with public input in 1994 will continue to be implemented in 1995, with emphasis on the stabilization of liquids and consolidation of special nuclear material. As facilities are deactivated, decontaminated, and decommissioned, site use plans will be implemented to develop appropriate alternative uses for facilities.

A new contracting method will be implemented, with one performance-based integrating contractor and several specialized subcontractors providing the government a high level of technical capabilities in a cost-effective manner. Also, the Economic Development team is working to develop new opportunities to convert the workforce to privare business enterprises. These initiatives include creating an onsite business development program for current site workers affected by the change in mission, developing economic conversion initiatives, and generating a Comprehensive Rocky Flats Environmental Technology Site Economic Development Strategy that will incorporate stakeholder participation into planning for the future of the site and the surrounding communities.

In 1996, using its Environmental Management budget request of $\$ 639.9$ million, Rocky Flats will continue assessment and remedial action activities. Economic conversion of one production facility will be essentially complete, and a private company will begin operating this facility under a lease agreement in 1997.

\section{Nevada Test Site, Nevada}

The Nevada Test Site is located about 65 miles
northwest of the City of Las Vegas. The site
encompasses 1,350 square miles of desert and
mountainous terrain. The site is surrounded on
three sides by the Nellis Air Force Range, which
provides a substantial buffer berween the site and
the communities located in the area. The primary
mission of the site has been weapons testing.
Through 1992 , when the President halted
underground nuclear testing, the United States
conducted 1,054 nuclear tests, of which, 928
occurred at the Nevada Test Site. The remaining
126 nuclear tests were conducted at other sites in
and outside of Nevada.

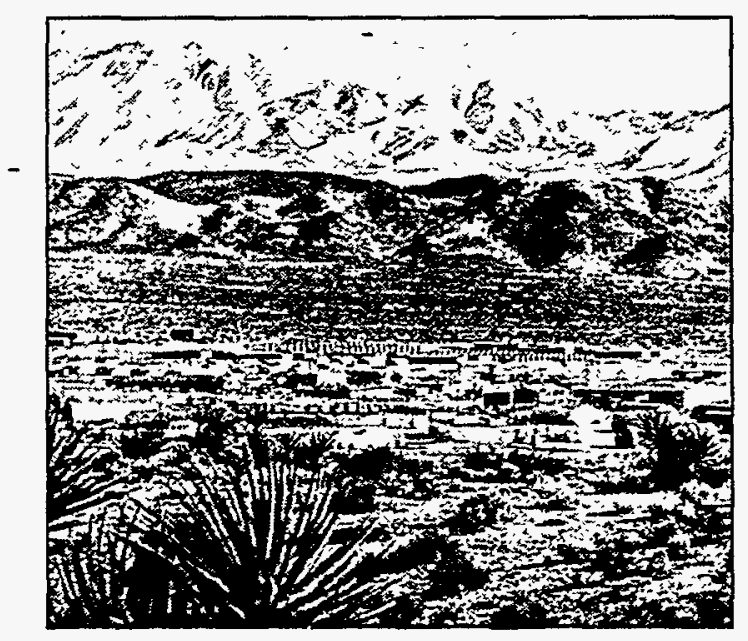

The Nevada Test Site.

The 1992 weapons testing moratorium resulted in a total cessation of nuclear weapons testing. The focus has now shifted to remediation of inactive sites and facilities that were contaminated during
Navada Test Site 1994 Performance

Nevada, as of September 1994, was 14 percent behind schedule and 3 percent under budget. 


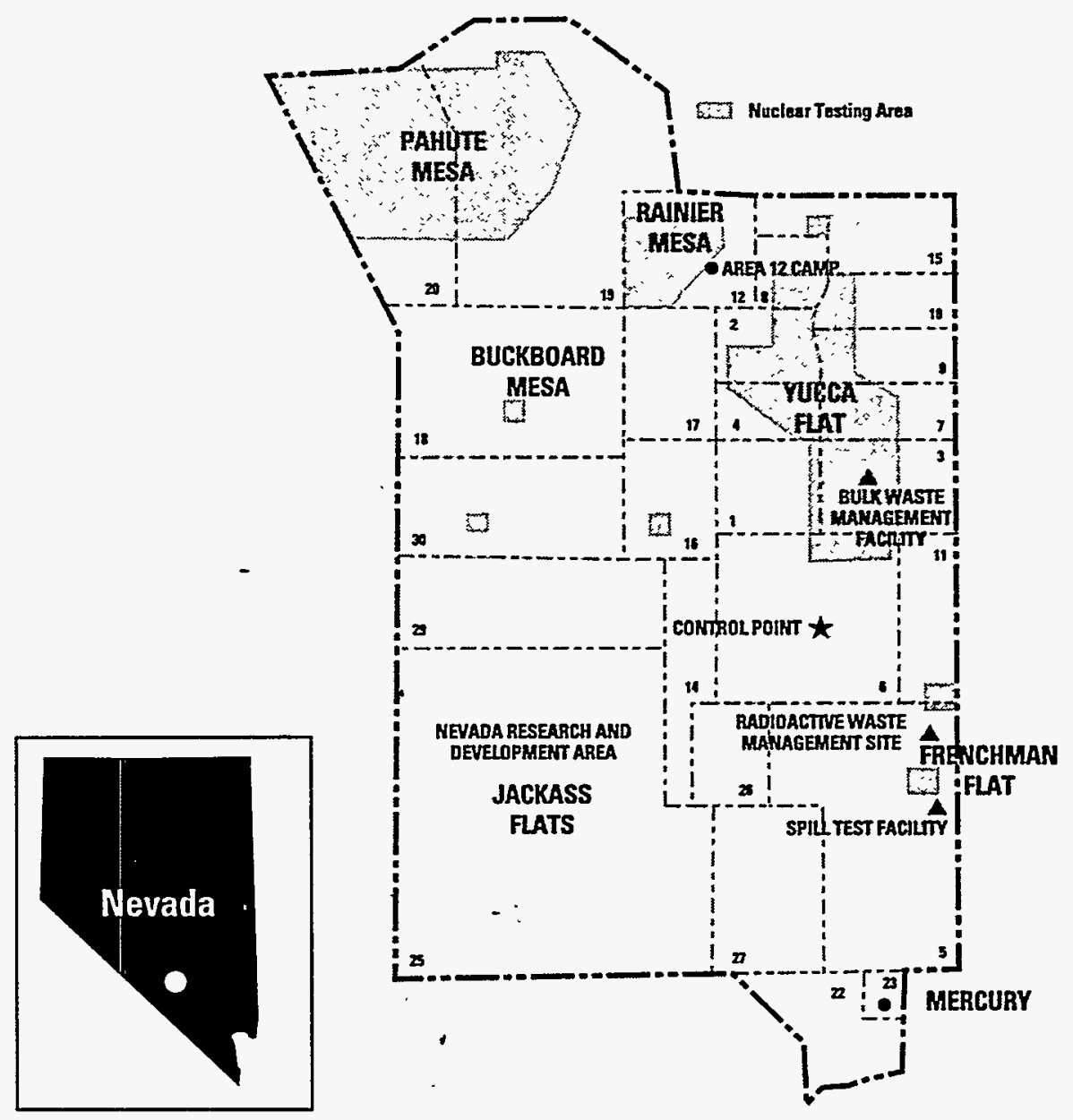

Figure 4. Map of the Nevada Test Site.

earlier testing activities. The Nevada Operations Office is working with the State of Nevada to develop a compliance agreement, under the Resource Conservation and Recovery Act and the Atomic Energy Act, addressing projected site remediation activities.

In 1994, the Environmental Management budget for the Nevada Test Site was $\$ 72$ million. A large portion of this budget was used to operate a variety of waste facilities at the Nevada Test Site. Low-level radioactive waste that originates at the Nevada Test Site, and from other Department installations, is disposed of onsite. Additionally, the site is utilized to temporarily store mixed transuranic waste from the Lawrence Livermore National Laboratory. Additional limited mixed waste disposal for waste generated offsite may be available, pending completion of the Nevada Test Site's Site-Wide Environmental Impact Statement and approval from the State of Nevada for the site's mixed waste analysis plan. An expanded mixed waste disposal facility will be constructed if the State of Nevada issues the RCRA Part B permit that is being modified to address State comments. The revised permit application for the mixed waste disposal facility is expected to be submitted to the State of Nevada by October 1995. Construction will begin within 180 days of receipt of the final permit.

During 1994, significant accomplishments in environmental restoration were made. Groundwater characterization wells were drilled and hydrologic data was collected to develop regional ground-water flow, transport, and risk assessment 
estimates. The Area 27 Explosive Ordnance Disposal site remediation, employing a streamlined approach for environmental restoration, was completed. Abandoned sepric tanks at the site were removed. Offsite nuclear test and experiment locations in Colorado, Mississippi, Nevada, and New Mexico were monitored to ensure there was no migration of radionuclides at these sites.

In 1995, with a budget of $\$ 64.5$ million, planned activities include continuing assessment of the underground nuclear testing areas, removal of underground storage, closure of two RCRA sites, and continuation of environmental restoration site inventory activities. Development of closure plans under the Streamlined Approach for

Environmental Restoration will continue. Field work will continue on Narive American resources surveys and on field investigations at various locations throughour the site. Remediation of underground storage tanks, and initiation of landfill remediation activities, will be initiated in 1995.

Completion of the Sire-Wide Environmental Impact Statement is scheduled in 1996. A Realtime Radiography building, which uses $\mathrm{x}$-rays to help determine contents of waste drums without opening them, and a Breaching and Sampling building, which can puncture sealed drums and safely remove samples for analysis, will be constructed in the late 1990's for verifying waste types shipped from other waste generators. The construction of the liquid waste treatment system and completion of the Radioactive Waste Management Site Performance Assessment is also scheduled. Nevada Test Site's 1996 requested budget is $\$ 76.2$ million.

There are four additional sites in Nevada that require remediation. More information on these sites can be found on page 33 .

\section{Waste Isolation Pilot Plant, New Mexico}

The Waste Isolation Pilot Plant is located 26 miles east of Carlsbad in Eddy County, New Mexico. The sire covers 10,240 acres of Federal land and is located 2,150 feet below the surface in a 2,000foot-thick salt bed with tunnels that extend over 10 linear miles. The Waste Isolation Pilor Plant provides a research and development facility to derermine the suitability of the sire for thesafe disposal of defense-related transuranic mixed waste. The transuranic waste destined for the Waste Isolation Pilor Plant is currently in temporary storage at waste generator sites located in California, Colorado, Idaho, Illinois, Nevada, New Mexico, Ohio, South Carolina, Tennessee, and Washington.

The Waste Isolation Pilot Plant must comply with RCRA and Environmental Protection Agency regulations, and the Waste Isolation Pilot Plant Land Withdrawal Act of 1992 for storing, . managing, and disposing of transuranic waste. These include certification for disposal from the Environmental Protection Agency and permits from New Mexico. The Land Withdrawal Act established a new regulatory framework and statutory process for demonstrating compliance with environmental regulations. Experimental activities to gather information are needed to support that compliance application and performance assessment calculations are underway.

In October 1993, the Secretary of Energy announced a revised test strategy for the Waste Isolation Pilot Plant. The new strategy involves conducting radioactive waste tests in laboratories instead of in the underground rests as originally planned at the Waste Isolation Pilot Plant. This will accelerate the regulatory compliance needed for a disposal decision, resulting in permanent disposal of transuranic waste earlier than originally planned.

With a budget of $\$ 178.8$ million in 1994 , the project complered key programmatic and Land Withdrawal Act milestones, in addition to the announcement of the new test strategy, such as submitting the Environmental Compliance Biennial report. In addition, the program also developed a Strategic Plan, submitted the application for renewal of the Cerrificate of Compliance on the Transuranic Package Transporter, and issued a Land Management Plan and a Transportation Alternatives Study to Congress. This budget was also utilized to maintain the site and continue ongoing nonradioactive testing at the site and national laboratories. The program also supported institutional review groups, including the Environment Evaluation Group, the New Mexico Environment Department, National
Three Areas Nevada Test Site Will Measure Its Performance in 1995:

Perform 3 assessments, 15 interim actions, and 1 final remediation. 
The Waste Isolation Pilot Plant is currently scheduled to begin accepting waste in 1998

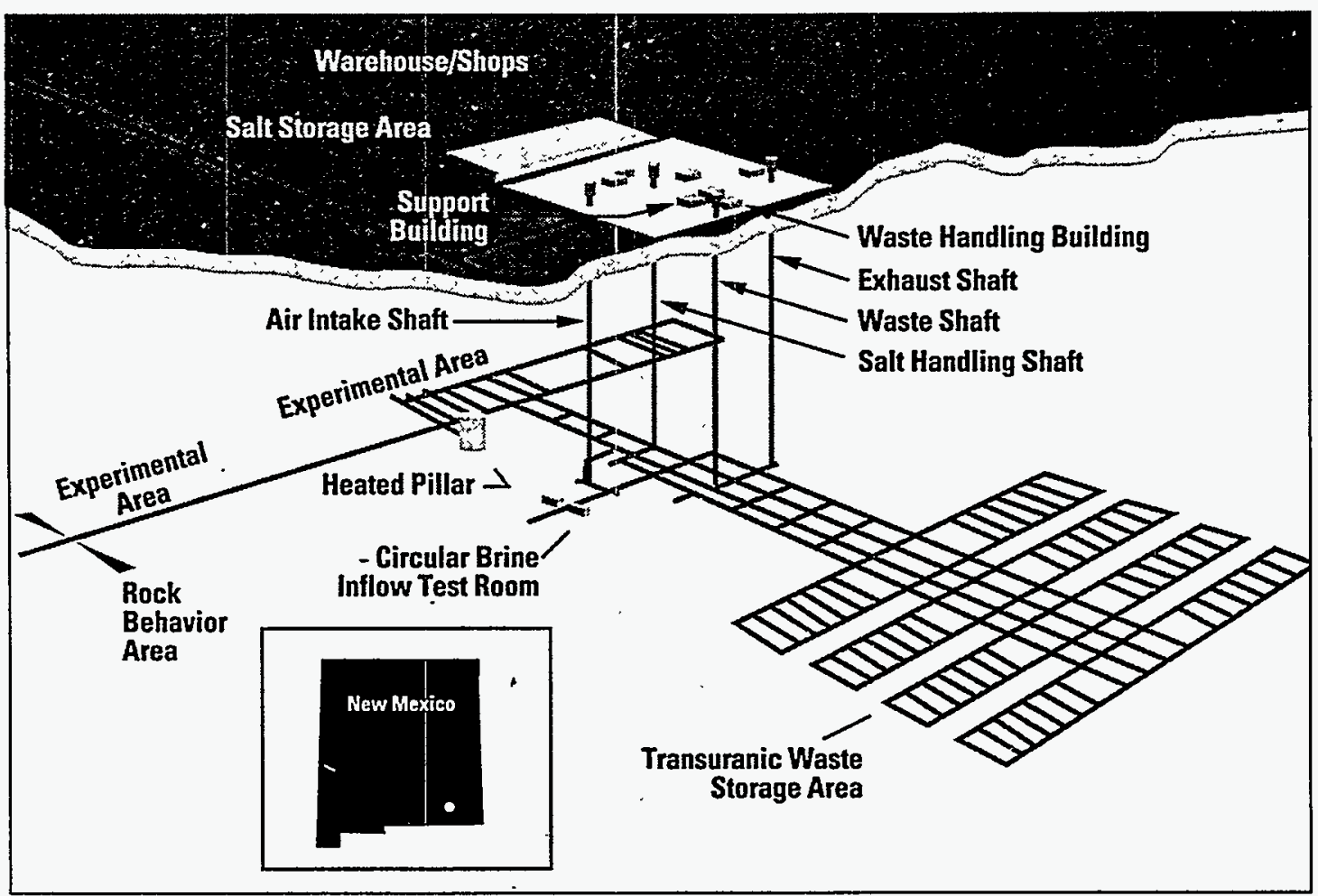

Figure 5. Cross section of the Waste Isolation Pilot Plant.

Academy of Sciences, the Western Governors' Association, the Southern States Energy Board, and the State of New Mexico.

The National Transuranic Waste Program Office was created to integrate and coordinate the disparate parts of the transuranic waste system. This will be accomplished by the National Transuranic Waste Program developing strategic plans, options, recommendations, and program guidance for transuranic waste generation, characterization, certification, handling, treatment, processing, packaging, storage, transport, and disposal. These activities and others are being accomplished with a budget of $\$ 174.3$ million in 1995.

Activities planned for 1996 include maintaining the facility and conducting waste characterization activiries required for accelerated compliance. The Department plans to submit a draft Compliance Certification application to the Environmental Protection Agency in 1995 and a final application in 1996. Nonradioactive testing and support for institutional groups, as well as resting at laboratory sites, will continue in 1996. The requested budget for 1996 is $\$ 172.7$ million.

\section{Arizona}

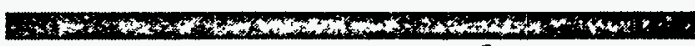

Arizona has two sites, Monument Valley and Tuba City. Both sites, locared in northern Arizona, are part of the UMTRA project. Information on these sites begins on page 38 .

\section{Colorado}

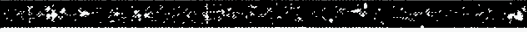

In addition to the Rocky Flats Environmental Technology Site, Colorado has 11 sites, 2 of which were used for underground nuclear explosive experiments. The test sites, Project Rulison, near Parachute, and Project Rio Blanco, near Rifle, are each a few acrès in size. The Department of Energy developed forecast baselines for each and is 
conducting hydrological monitoring to ensure radiological contaminants do not migrate to public water sources. Site assessments for both sites will be initiated in 1994 and will continue through 1995. Contamination from the hole drilling mud pir will be investigated. Most of the remaining sites are part of the UMTRA project. These include Gunnison, Durango, Grand Junction, Maybell, Naturita, Old Rifle, New Rifle, and Slick Rock, which was the old Union Carbide and North Continent sites. Information about these sites begins on page 38 .

The Grand Junction Projects Office is locared immediately sourh of the City of Grand Junction on a 56-acre site adjacent to the Gunnison River.

The Grand Junction Projects Office supports the Environmental Management program in the areas of site characterization, project integration and coordination, remedjal design, remedial action, independent verification, and decontamination and decommissioning. The site also provides long-term surveillance and maintenance, assessment of rechnology needs, and geoscience and analytical chemistry.

In 1994, with a budget of $\$ 30.6$ million, the Grand Junction Projects Office removed 84,000 tons of tailings from the sire and reconstructed a river dike and wetlands to meet Army Corps of Engineers requirements. Five buildings were decontaminated and decommissioned to reduce potential health risks. The site was also recontoured, and topsoil was placed in areas that are being revegetated.

These activities will continue in 1995 with a budget of $\$ 38.1$ million. In addition, 61 cubic meters of polychlorinated-biphenyl-contaminated tailings will be disposed of, 2 buildings will be decontaminated, and ground-water monitoring will continue. Grand Junction Projects Office's 1996 budget request is $\$ 50.9$ million.

Long-Term Surveillance and Maintenance program funding was estimated ar $\$ 426,000$ for 1994. During that year, the Spook, Wyoming, and Burrell, Pennsylvania, sites were transferred to the Long-Term Surveillance and Maintenance program. Inspection and maintenance was completed at Spook, and maintenance was completed at Burrell. Responsibility for the Department of Energy's pre-licensing and postlicensing Title II site activities was assigned exclusively to the Grand Juncrion Projects Office. A
Task Force on Title II sites was established to address the Department of Energy's role in licensing and transfer of the sites.

\section{Nevada}

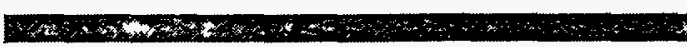

In the State of Nevada, there are four sites that require remediation. The sites are the Nevada Test Site (discussed on page 29), the Project Shoal site, the Central Nevada Test Area, and the Tonopah Test Range. From 1961 through 1973, the Project Shoal and the Central Nevada sites were offsite locations used by the Department to conduct underground nuclear tests and experiments. Site assessments began in 1994.

The Tonopah Test Range was established in 1957 for ballistics testing of nuclear weapons, parachute delivery systems, and other nonnuclear functions for Sandia National Laboratories. During 1994, a site assessment was conducted, as well as environmental restoration site inventories, surface and aerial surveys, and a risk assessment. These surveys identified 14 potential release areas in need of characterization. Before sampling can proceed, a concerted effort to remove unexploded ordnance from five of the disposal sites must take place to protect site workerrs from potential hazards. This effort, initiated in February 1995, involved the remote handling and detonation of potentially live ordnance. Field sampling activities will begin in 1995 to determine the nature and extent of contamination at the identified sites.

\section{New Mexico}

In addition to the Waste Isolation Pilot Plant, New Mexico has 12 sites. The sites include FUSRAP sires, UMTRA sires, research laborarories, and test sites. The FUSRAP sites include Chupadera Mesa, completed in 1984; Bayo Canyon, completed in 1982; and the Acid/Pueblo Canyons, completed in 1982. The UMTRA sites in New Mexico include Ambrosia Lake and Shiprock. Information about these two UMTRA sires begins on page 39 .

The Los Alamos National Laboratory encompasses over 43 square miles in northern New Mexico and has a total operating budget in excess 
of $\$ 1$ billion. The University of California operates the Laboratory under a contract for the Department of Energy. Major programs include applied research in nuclear and conventional weapons development, nuclear fission and fusion, nuclear safeguards and security, and environmental and energy research. The Laboratory's core competencies are nuclear science, plasmas, and beams; modeling and high-performance computing; bioscience and biotechnology; and earth and environmental systems.

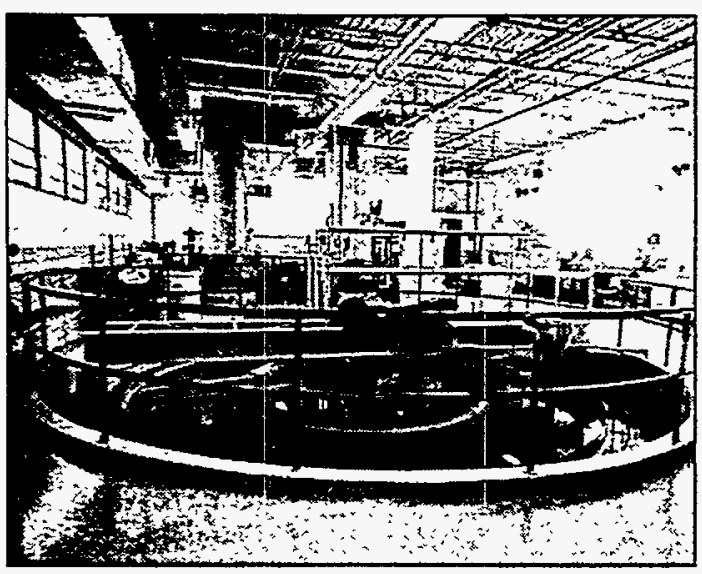

The Radioactive Liquid Waste Treatment Plant at Los Alamos National Laboratory.

The Laboratory's Environmental Management budget for 1994 was $\$ 183.7$ million. By the end of 1994, Los Alamos had removed hazardous materials from 50 areas onsite, which served a variety of purposes such as high-explosive treatment systems, underground storage tanks, septic systems, and contaminated soils. The site also dismantled a major building used to process uranium, eliminating the source for 75 percent of the onsite radioactive emissions. A new technology, the Long Range Alpha Detector, was developed to measure the charged particles produced in air from radiation. Using this technology's wide range of sensitivity, up to 30 sites per day can be monitored without disturbing the soil or generating waste byproducts. To date, eight commercial units have been built.

During 1995, with an Environmental Management budget of $\$ 162.2$ million, Los Alamos will continue to develop technologies and processes to address environmental issues. For example, waste treatment facilities will be designed and constructed to serve as a test bed for developing emerging rechnologies. The program will then use these facilities to service laboratory waste generators and demonstrate innovative treatment rechnologies to potential customers. The Laboratory will complete and submit Facility Investigation reports covering 350 potential release sites, complete up to 60 expedited remediation actions, and complete two RCRA closures in 1995. Decontamination and decommissioning work will include assessing seven buildings housing highly explosive materials and one filter building.

In 1996, with a requested Environmental Management budget of $\$ 135.9$ million, Los Alamos will continue its waste minimization, environmental restoration, and waste management activities at its own sites and others within the Department of Energy complex. By 1996, the Laboratory will have collaborated with Hanford and Rocky Flats to address several environmental management issues. In addition, the Laboratory will continue to collaborate with other Government agencies, academia, and industry, as well as further develop and augment methods for effective business operations.

Project Gnome-Coach and Project Gasbuggy are locations where underground explosive nuclear tests and experiments were conducted from 1961 through 1973. These sites are currently inactive. Site assessments are scheduled to begin in 1996. Long-term hydrological monitoring is being conducted at both sites to detect potential radiological contamination migrating to potable water sources.

From 1951 to 1967, the South Valley Site near Albuquerque was owned by the Atomic Energy Commission and operated by the American Car Foundry Company. Operations included electroplating, machining, painting, adhesive, and degreasing related to weapons production, reactor design, and space programs. As a CERCLA porentially responsible party under a tri-party agreement with the Air Force and General Electric, the Department of Energy is responsible for environmental restoration activities at the plant site. Soil and ground-water contamination is being remediated by using vapor extraction and pumpand-treat technologies. In 1994, a ground-water remediation system was constructed and operated to remove volatile organic compounds from the shallow aquifer. Monitoring and characterization of 
the deep aquifer zone plume continues. In 1995, a remediation system will be constructed to remove volatile organic compounds from the deeper levels of the aquifer. Two former municipal water wells will be plugged. In 1996, the larger deep aquifer remediation system will be operated, and the shallow aquifer remediation system will be evaluated to determine if remediation goals have been mer.

Albuquerque, New Mexico, is also home to the Sandia National Laboratories, a research and development facility with a primary mission of developing, engineering, and testing nonnuclear components of nuclear weapons.

During 1994, Sandia National LaboratoriesNew Mexico completed urgent environmental protection and corrective activities, including installation of a meteorological monitoring network, construction of a reactor facility liquid effluent discharge control system, and sewer system repairs. Waste management efforts focused on developing radioactive waste facilities, operations, and disposal options. Sandia successfully shipped mixed waste debris to a commercial disposal facility, marking the first time the site has shipped radioactive waste offsite for disposal. An application was submitted to ship low-level radioactive waste to the Nevada Test Site. Sandia also developed an option for disposal of excess rocket motors that were used for sled track and impact tests. Efforts continue to implement the requirements of the Federal Facilities Compliance Act for mixed waste management. A Draft Site Trearment Plan was submitred in 1994 and will be finalized during 1995 , outlining the site's strategy for trearment and disposal of mixed waste. Sandia completed surveys of unexploded ordnance and surface radiation and voluntary corrective measures in Technical Area II. The site also began radiation remediation and voluntary corrective measures for uranium calibration pits.

Sandia conducted work to address the technology needs to reduce waste and hazardous materials generated during the production of electronic components for the Environmentally Conscious Manufacturing Integrated Demonstration. Substitutes to replace toxic substances now used in cleaning electronics were investigated. One such substitute, supercritical carbon dioxide cleaning, provides a non-toxic, recyclable, and relatively inexpensive alternative.
In addition, the SEAMIST ${ }^{T M}$ sensor emplacement technology developed at the Mixed Waste Landfill Integrated Demonstration received an award as one of the top 100 new technologies in the United States. SEAMIST ${ }^{\mathrm{TM}}$ is an instrument and fluid sampler technique designed for in situ characterization and monitoring. The Hybrid Directional Boring and Horizontal Logging

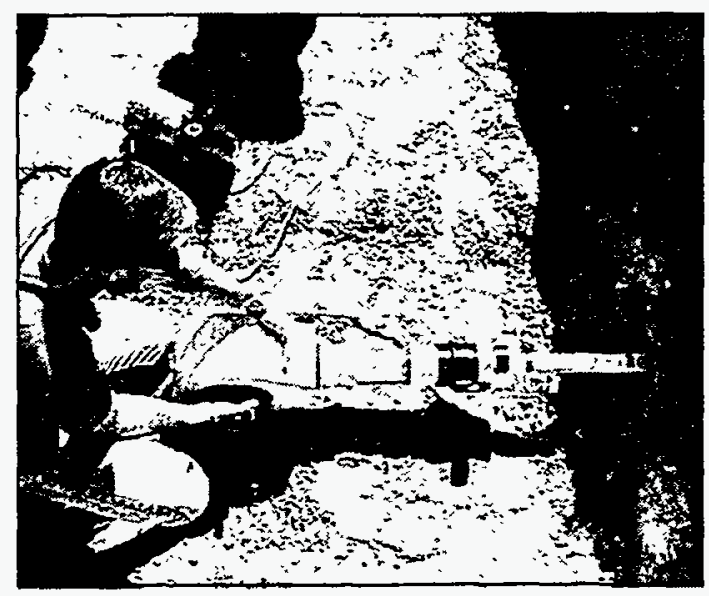

Seamist ${ }^{T M}$, recognized as one of the top 100 most significant technological developments by RED Magazine in 1994, was developed.at Sandia National Laboratories.

method, a cost-effective technology to access otherwise inaccessible contaminared surfaces, was developed at Sandia. This technology minimizes the number of boreholes needed using conventional drilling methods and eliminates the production of secondary waste because the technology does not use cutting fluids. Costs using directional drilling are berween $\$ 20-75$ per foor compared to $\$ 300$ per foot using conventional equipment. This technology was used at Kirtland Air Force Base in the spring of 1994 and has been successfully transferred to a private company. These activities were accomplished with the 1994 Environmental Management budger of $\$ 74.7$ million.

In the coming year, Sandia National Laboratories-New Mexico will focus on developing mixed-waste treatment and disposal capabilities while maintaining a strong RCRA waste management program. Efforts will continue to improve waste management facilities, and a pollution prevention strategy will be implemented. Fieldwork at the Mixed Waste landfill and the Chemical Waste Landfill monitoring well network 
will be completed, and several voluntary corrective actions will be conducted. The 1995

- Environmental Management budget for Sandia National Laboratories-New Mexico is $\$ 69.2$ million.

Sandia will, in 1996, continue to pursue actions for trearment and disposal as developed under the Federal Facility Compliance Act process. Efforts will also continue to reduce the inventory of legacy materials at the site and prepare for increasing amounts of waste as a result of environmental restoration projects. For 1996, Sandia will continue to identify areas onsite for No Further Action approval and conduct voluntary corrective measures. Sandia will request Environmental Management funds of $\$ 41$ million for 1996.

Sandia National Laboratory-New Mexico has generated chemical, radioactive, and mixed waste at a number of off-base locations, including one building at the Holloman Air Force Base near Albuquerque.

The Inhalation Toxicology Research Institute, in Albuquerque, conducts studies on the health effects of inhaling potentially hazardous airborne materials that might be found in industry, the environment, or the home.

During 1994, with an Environmental Management budget of $\$ 3.2$ million, the Institute completed and resolved all issues associated with an application for shipment of low-level waste to the Nevada Test Site. In addition, the Institure's waste management program identified offsite commercial facilities to treat its entire inventory of mixed waste. It also completed its plans to ship existing mixed waste offsite to commercial facilities for treatment and disposal. The Institure also completed the Draft Site Treatment Plan under the Federal Facility Compliance Act. The sire successfully closed four of five diesel oil spill sites. Remediation of its Hot Pond site began in 1994 and is expected to be completed by the end of 1995 . The Institute was consistently ahead of schedule and under budget in environmental restoration in 1994.

During 1995, the Institute will focus on closing interim status storage facilities at the site. The Institute will also continue to pursue mixed-waste treatment technologies and will complete and submit the final Site Treatment Plan under Federal Facility Compliance Act. The Institure will seek approval from the Nevada Operations Office to continue shipments of low-level waste to the
Nevada Test Site. Attention will also be focused on waste minimization through pollution prevention and upgrading the chemical inventory and procurement systems. In 1995, the Institute will focus on the removal and remediation of its Lagoon Sludge site. The site is expected to be closed in 1995 when ground-water cleanup tests begin. The cleanup tests will be used to confirm that the ground water needs no further cleanup. The Institure's total Environmental Management budget for 1995 is $\$ 2.4$ million.

In 1996, the Institute plans to continue waste minimization efforss and management of all waste types. One focus will be on disposing the sludge removed from the Lagoon Sludge site. The goal in 1996 is to end all significant environmental restoration activities with an Environmental Management budget of $\$ 2.3$ million.

The Pagano Salvage Yard, located in Los Lunas, was placed on the National Priorities List in 1994. The Sandia National Laboratory and the Department were named Porentially Responsible Parties, making them partially responsible for cleanup. The Environmental Protection Agency Region VI completed a removal action, and there was an enforceable agreement between Sandia and the Environmental Protection Agency for cost reimbursement for the removal action. The Department reimbursed the Environmental Protection Agency \$2.5 million in 1994 and no longer has any responsibility for the site.

\section{Texas}

Texas has two sites requiring remediation. The Falls City site is part of the UMTRA project and is discussed on page 40.

The Pantex Plant, near Amarillo, is responsible for assuring the quality of the Nation's nuclear weapons stockpile, including dismantlement and maintenance. In addition, the site conducts research and development of various explosives in support of weapons design, development, and production engineering for the Department of Energy. In 1994, the site was placed on the National Priorities List, thereby requiring remediation under CERCLA authority. DOE is working closely with the regulators to integrate 
both the RCRA and CERCLA requirements in order to avoid costly duplication of remediation activities while meeting remediation goals.

Environmental restoration activities at the site include the assessment of 144 solid waste management areas. In 1994, with an Environmental Management budget of $\$ 29.9$ million, regulatory approval was received on the last of the 14 RCRA Facility Investigation work plans. Initial phases of fieldwork have been completed for 11 of 15 investigations, and No Further Action requests have been submitted on three areas. Planning for an interim correct measure began for one site, and an expedited site characterization project for Pantex ground water was initiated. A Facility Action plan has been submitted to accelerate the program by two years and save almost $\$ 67$ million from the target budget through 2002. Pantex was placed on the National Priorities List in 1994.

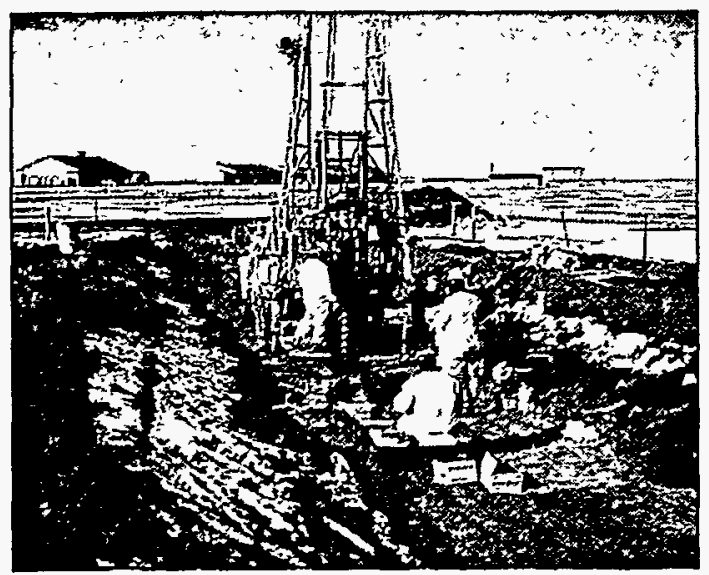

The soil boring drilling rig and samplers used to close a former waste water pond at Pantex.

Pantex also completed the Conceptual and Draft Site Treatment Plans for mixed waste and succeeded in becoming the first Department of Energy site to ship mixed waste to Envirocare of Utah for disposal. Waste management activities at the site include characterizing and tracking all waste. More than 2,300 weapon components were characterized, and 35 waste streams, identified on the State's Notice of Registration, were characterized. Pantex shipped its current inventory of low-level waste to the Nevada Test Site. Pantex submitted three RCRA closure plans in 1994.
In 1995 , with a budget of $\$ 40.4$ million, findings of No Further Action for another 4 areas will be proposed. A significant amount of characterization is planned so that Pantex can submit decisions of No Further Acrion on an additional three sites. Pantex will focus on development of mobile units for treatment of mixed waste. The site plans to ship additional mixed waste to commercial facilities for treatment and/or disposal. The Final Sire Treatment Plan for mixed waste will be submitted to the State of Texas, and conceprual designs will be completed on a hazardous waste treatment and processing facility. Pantex will also continue its waste minimization efforts.

In 1996, with a requested budget of $\$ 21.2$ million, two other areas will be approximately 50 percent remediated. Pantex expects to complete the design of the hazardous waste treatment and processing facility. Pantex will also request three additional No Further Actions decisions in 1996. Remediation of two additional sires and Voluntary Corrective Activities on five sites will also continue. The weapon component characterization program to facilitate the stockpile dismantlement will proceed, and Pantex will continue minimizing waste produced onsite.

Utah

Urah has three completely remediated former processing sites that are part of the UMTRA Project: Salt Lake City (Vitro), Green River, and Mexican Hat. Information on these sites on page 38.

The Monticello Millsite and Vicinity Properties includes remediation of a former uranium mill site, vicinity properties, and assessment of surface and ground-water contamination near Monticello, Utah.

There are 411 vicinity properties. During 1994, remediation of peripheral properties and preexcavation of the millsite continued, and construction at 62 vicinity properties was also completed. With a 1995 budget of $\$ 23.9$ million, the Monticello Project plans to initiate final design for the onsite repository and complete remedial action on four peripheral properties. In addition, construction will be completed on 81 viciniry 
properties. The current 1996 budget request is $\$ 34.4$ million. Remedial action on 4 peripheral properties and construction at 26 vicinity properties will be completed.

The 1996 budger requesr is $\$ 33.7$ million.

\section{FUSRAP and UMTRA Sites}

Whing

Environmental management activities at all three FUSRAP sites, Chupadera Mesa, Bayo Canyon, and Acid/Pueblo Canyon, are complete. These sites are located in New Mexico.

At all of the UMTRA sites in this region, there is residual ground-water contamination. However, this warer is not used as a source for drinking water. The Programmatic Environmental Impact Statement discussed on page 4 will also address ground-water compliance, proposed actions, and alternatives for the sites in this region. Hearings on the document are scheduled for early 1995.

Following Baseline Risk Assessments of the ground water at the sites in this region, the Department will meet with local citizens and government officials to discuss the initial analysis. Further acrions will be taken, as necessary, to achieve compliance with the standards outlined by the Environmental Protection Agency. Surface activities were completed at four of the UMTRA sites in the Southwestern region in 1994. Activities began at one site, and surface cleanup continues at four other sites in this region.

The Grand Junction former processing site and tailings, also known as the Climax Mill Site, is a 114acre tract located in Mesa County in an industrial area of the City of Grand Junction, Colorado. The site contained one large tailings pile of 2.5 million cubic yards and a remaining mill building. Materials from vicinity properties were deposited on the site in the State repository located northeast of the pile. In 1951, Climax Uranium Company, a division of American Metals Climax (now known as AMAX, Inc.), started milling operations at the site; the mill was shur down in March 1970.

Remedial action and restoration was completed at the Grand Junction site in August 1994. At the Cheney disposal cell onsite riprap production, radon barrier, and frost barrier placement on side slopes of the disposal cell were completed. Plans for 1995 through 1996 are to continue remedial actions at vicinity properties, including initiating remediation at commingled properties. The

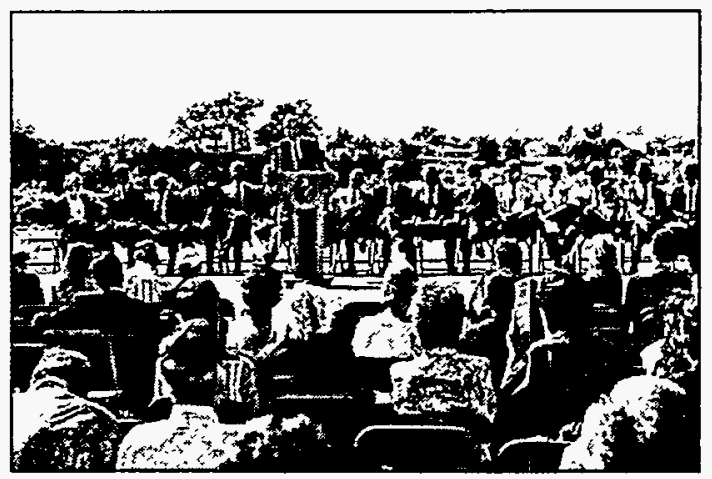

Department of Energy Deputy Secretary William White delivers the keynote speech at the Grand Junction, Colorado, Site Closing Ceremony on September 8, 1994. This was the 12 th, and largest, site where remediation was completed under the UMTRA project.

disposal cell at Cheney will remain open to continue receiving vicinity property materials.

Site remedial action and restoration at the Monument Valley former processing sire was completed in 1994. The site is on Navajo Nation land, 13 miles east of Monument Valley Tribal Park in Arizona, and 5 miles south of the Urah-Arizona border. The sire covers approximately 90 acres and contained 2 piles covering about 30 acres. The mill was constructed in 1955 and operated through 1968. Interim surveillance and monitoring and site certification activities will continue through 1995 , until certification is received.

The Tuba City site, also on Native American Tribal lands, is located 5.5 miles east of Tuba City, Arizona, 85 miles north of Flagstaff. Remedial activity was completed in May 1990 . The site contained about 800,000 cubic yards of material on 105 acres, of which 22 acres were covered by tailings and 44 acres were former evaporation ponds. The remaining acres were a result of windblown contamination. The site is scheduled for licensing and certification in 1995. The Tuba City site will transfer site responsibilities to the Grand Junction Projects Office under the LongTerm Surveillance and Maintenance Program in 1995.

The Salt Lake City, or Vitro, site, covering 128 acres, is located 4 miles southwest of the center of Salt Lake City. The sire, now owned by the State of Utah, was used to process uranium ore until 
January 1964 and was dismantled in 1970. Remediation was completed in 1988. In 1994, the Department began preparing site completion reports and conducted interim surveillance and maintenance activities. These activities will be completed in 1996. After certification and licensing, site responsibility will be transferred to the Grand Junction Projects Office under the Long-Term Surveillance and Monitoring program in 1997.

The Durango former processing site, where - remediation began in 1986, is located just ourside the city limits of Durango in southwest Colorado. The site covers approximately 147 acres and included two tailings piles. The cell was completed and closed in May 1991. Interim surveillance and monitoring, site certification, and site licensing activities will continue until the site is transferred to the Grand Junction Projects Office under the Long-Term Surveillance and Maintenance Program.

The Gunnison former processing site is located southwest of the City of Gunnison, Colorado, adjacent to the Gunnison airport. The site covers 61 acres, 39 acres of which are covered by tailings. The site is owned by the State of Colorado. In 1994, remedial action was completed. Goals for 1995 include placement of radon barrier, frost protection, and completing riprap production. Riprap placement and remediation are planned to be complete by November 1995 .

The Maybell former processing site and tailings pile is located roughly 25 miles west of Craig, Colorado. The site covers 110 acres, with several open-pit mines surrounding the site and an additional 182 acres of land containing contamination deposited by wind or water erosion from the site. During 1994, National Environmental Policy Act documentation and the remedial action plan were prepared. Remedial action will begin in 1995, with site preparation, tailings excavation, and production of erosion protection materials. Remedial action will be initiated and completed at all six vicinity properties associated with the site. Preliminary plans for 1996 call for radon barrier placement and frost protection completion. Erosion protection will be placed, along with ongoing site remedial and restoration activities. Site remedial action is scheduled to be completed by December 1996.
The Naturita former processing sire is located two miles northwest of the Town of Naturita in Montrose County, Colorado. The site is a 53-acre area that was operated from 1939 until the end of World War II by the Vanadium Corporation of America for vanadium recovery. Accomplishments include preparation of final environmental assessment in November 1994, and the Remedial Action Plan, completion of processing site demolition, and initiation of vicinity property remedial action. Initiation of Phase II remedial action, including site preparation, tailings excavation, and shipments, are scheduled to begin in 1995. Completion of site remedial action and initiation of interim surveillance and monitoring activities is expected in 1996.

The former processing sites at Rifle lie in the Colorado River valley near the Ciry of Rifle, Colorado. The sites are about two miles apart and are referred to as the Old Riffe and New Rifle sites. Old Rifle is a 22-acre site; New Rifle covers approximately 33 acres. The Old Rifle site operated from 1924 to 1932 for the recovery of vanadium from roscoelite ore. The process was altered to include recovery of uranium from 1947 to 1958 . The New Rifle site operared from 1958 to 1973 as part of the complex of upgraders, including those located at Slick Rock, Colorado, and Green River, Utah.

In 1994, 64 percent of the site's remedial action was completed. In 1995, plans include initiation and completion of radon barrier, and frost barrier placement and erosion protection placement to complete 93 percent of remedial action. Site remedial action is expected to be complete by 1996.

The Ambrosia Lake former processing site is located in McKinley County approximately 85 miles northwest of Albuquerque, New Mexico. The 2.6 million cubic yards of tailings covered 105 acres to an average depth of 12 feet. Wind and water erosion also spread some of the tailings across a 570-acre area.

During 1994, the site complezed 95 percent of remedial action. Placement of erosion protection materials was initiated, and tailings and radon barrier placement were completed. Site restoration and remedial action erosion protection placement are expecred to be complete in 1995. Preliminary 
plans in 1996 include initiating interim surveillance and monitoring activities, and site certification.

Site remediation at the Shiprock site was completed in 1986. The former processing site is located on the Navajo Nation on the south side of the San Juan River, adjacent to the Town of Shiprock, New Mexico. The site is located on a 230-acre tract of land. Interim surveillance and monitoring activities continue until the site is licensed and transferred to the Grand Junction Projects Office under the Long-Term Surveillance and Maintenance Program.

The Falls City former processing site consists of two parcels located 46 miles southeast of San Antonio and approximately 8 miles southwest of Falls City, Texas. The mill was built and operated by Susquehanna-Western, Inc. of San Antonio, Texas, from 1961-1973. Between 1978 and 1982, Solution Engineering, Inc. extracted processed uranium from tailings piles, until 1982, when it was transferred to the Department of Energy. Subsequently, all piles were covered with a minimum of one and one-half feet of soil and vegetation.

In 1994, the site completed surface remedial actions, including cover placement, production and placement of erosion protection, and completion of site restoration. During 1995, the Falls City sire will initiate interim surveillance and monitoring and site certification activities, until certification and licensing take place in 1996.

The Green River site and tailings pile are located in the east-central portion of Utah in Grand County. The site covers approximately nine acres. Union Carbide built the uranium mill in 1958 and operated it until shutdown in 1961. Later, the mill buildings were used for assembly of missile components for the Utah Launch Complex.
Remedial action was completed in 1989. The site completed certification in 1992. In 1995, licensing is planned, and then site responsibility will transfer to the Grand Junction Projects Office under the Long-Term Surveillance and Maintenance Program.

The Mexican Hat former processing site, located at Halchita, Utah, on Navajo Nation land abour 1.5 miles southwest of Mexican Hat, Utah, covers approximately 555 acres. There were 2 adjacent tailings piles covering 25 and 48 acres each. The site is completely remediated. Accomplishments of 1994 included completion of tailings haul from Monument Valley, and radon barrier, and erosion protection production, placement of erosion protection, site restoration, and completion of site remedial action. Preliminary plans for 1995 include initiating interim surveillance and monitoring, and site certification activities.

There are two former processing sites at Slick Rock, Colorado, the Union Carbide Corporation site and the Old North Continent site. The sires are one mile apart and are locared northwest of the Post Office at Slick Rock in the Dolores River Valley. The Union Carbide Corporation site covers 93 acres and was acquired by Union Carbide in 1956, and the Old North Continent site, acquired a year later, covers 17 acres.

National Environmental Policy Act documentation and the site remedial action plan - and plans for the sire's final design continued during 1994. Sire remedial action will be initiated in 1995. Site preparation will be completed along with demolition activities. Tailings haul and erosion protection production will be initiated. Radon barrier, frost barrier, and erosion protecrion will be placed, and the processing site will be restored in 1996 when remedial action will be $100-$ percent complete. 


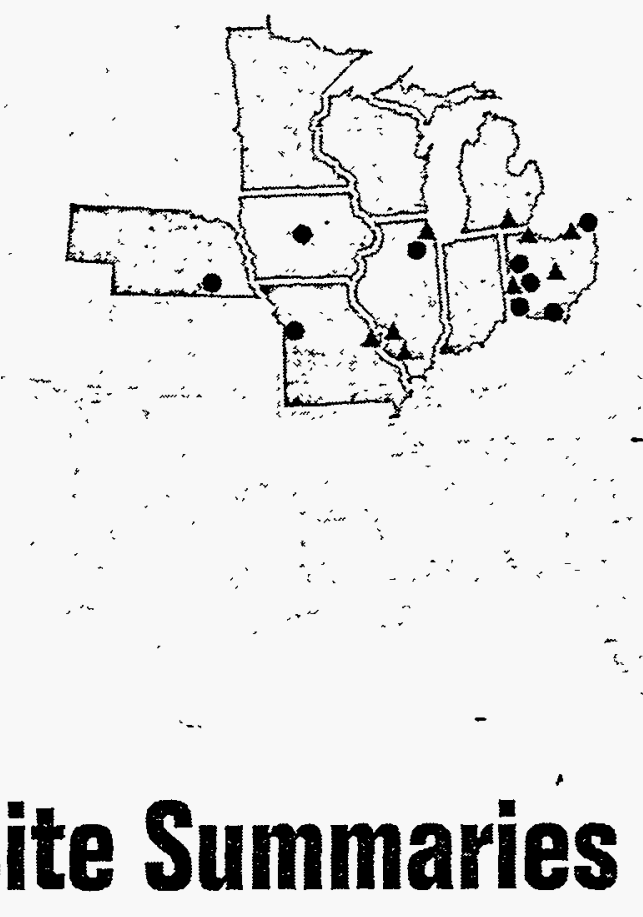

Environmental Management is conducting activities at sites in Illinois, Iowa, Michigan, Missouri, Nebraska, and Ohio. Of the 27 sites in the Central region, 16 are in various stages of remediation under the Formerly Utilized Sités Remedial Action Program (FUSRAP) and 4 are research laboratories. Summary performance and funding information is included in this section. More specific information on these sires can be found in the Performance and Funding Data section beginning on page 61 .

\section{Fernald, Ohio}

The Fernald Environmental Management Project is located on 1,050 acres approximately 18 miles northwest of Cincinnati, Ohio. From 1953 to 1989, the site produced uranium metals and compounds for the Nation's defense program. In 1989 , all production operarions were suspended. In 1991, production was permanently halted. The Fernald Environmental Management Project's main mission is remediation of the site and any offsite contamination in a timely, safe, and cost- effective manner. All intermediate removal actions have been completed to address immediate site risks. Final decisions on remedial alternatives will be made for all five areas by 1997 .

Fernald's 1994 total budger was $\$ 300.7$ million, most of which was designated for environmental restoration activities. There were several environmental restoration accomplishments at the site in 1994, and Fernald will build on these successes in 1995 to ensure the mission at Fernald is achieved. An interim Record of Decision for decontamination and decommissioning of more than 200 structures at Fernald was signed by the Department and the Environmental Protection Agency. The tallest building on the site, a seven-story structure, was decontaminated and imploded in 1994, and field activities for the dismantlement of five additional structures are scheduled for 1995. Approximately $\$ 1.6$ million was used to examine possible technologies to use in cleaning up the site, such as the Minimum Addition Waste Stabilization project. This new rechnology can process low-level and mixed waste into glass, combining several waste streams using an electrically heared melter in combination with soil washing and ion exchange 


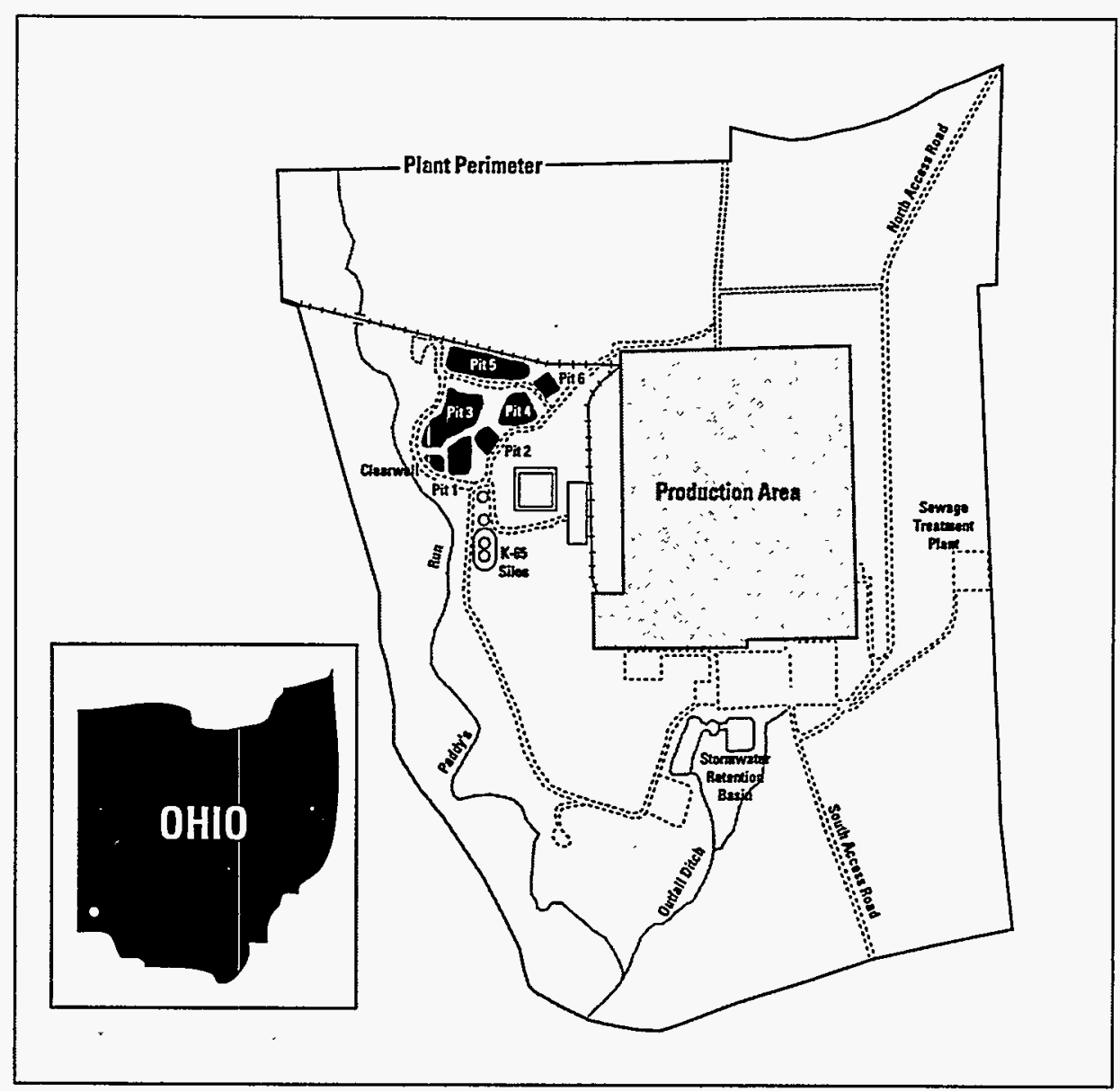

Figure 6. The Fermald Environmental Management Project is located 18 miles northwest of Cincinnati.

\section{Fernald Will Use the} Following Goals to Measure Its Performance in 1995

Perform 2 assessments, 3 interim actions, and 1 final remediation activity, and 3 final decontamination and decommissioning activities. wastewater treatment to minimize the use of additives. Waste loadings up to 95 percent were achieved in a 300-kilogram-per-day melter constructed and operated onsire. Construction of a new advanced wastewater treatment facility was completed during the past year. Startup and operation of that facility will begin in 1995.

Fernald's budget for 1995 is $\$ 261.7$ million, with 99 percent allocated for environmental restoration activities and 1 percent for technology development. Activities planned include implementing an extensive waste management program. The site is also planning to start shipping additional types of waste, such as asbestos, to the Nevada Test Sire. Mixed waste was shipped to a commercial disposal facility.

Fernald plans to submit three draft Records of Decision, or remediation plans, in 1995. Four of the five Records of Decision will have then been

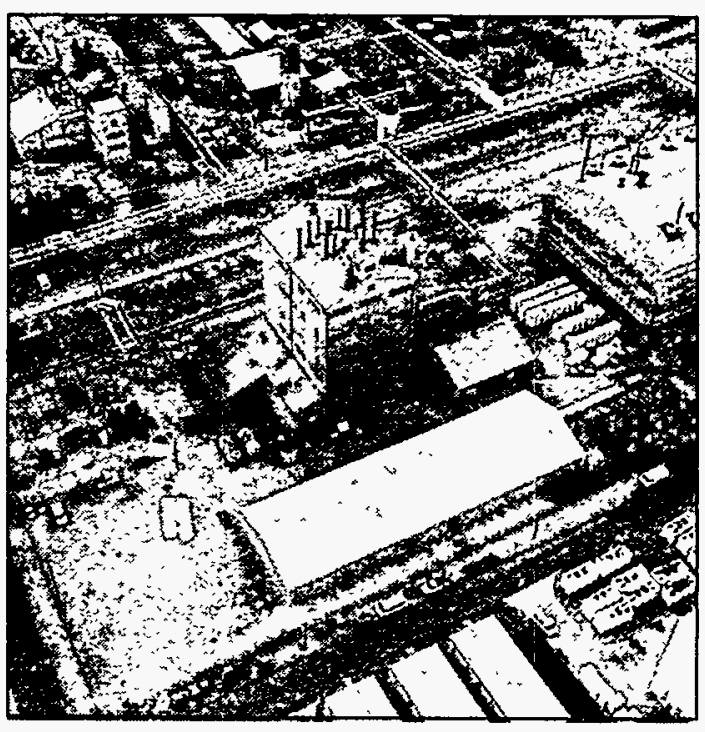

The tallest building on the Fernald site, Plant 7 , was decontaminated and imploded on September 17, 1994. 
submitted. Concurrently, it is anticipated Fernald's future land use plan will be prepared and submitted to Headquarters by Seprember 1995. A recommendation for the future use of the site is also being developed by the Citizen's Task Force, which is one of the many public participation activities taking place at the site. In 1995, construction of the virrification treatment facility for the processing of waste from the K-65 silos is planned.

Pump and treatment technology is being used to stop uranium-contaminated ground water from migrating further. Technologies to contain contamination, such as installing horizontal barriers, soil washing, and real-time uranium detection, are being demonstrated onsite. In 1996, Fernald will continue remedial design activities and implementation of the Records of Decision, with a requested budget of $\$ 256.3$ million.

Information on other sires in Ohio begins on page 46.

\section{Illinois}

Illinois has four FUSRAP sites: the University of Chicago, the National Guard Armory site, Granite City Steel, and the Madison site. Remedial action activities at all sites listed, with the exception of the Madison site, have been completed. Activities at the Madison site are described on page 48.

Argonne National Laboratory-East, near Chicago, conducts research to support the development of energy-related technologies. These research activities generate hazardous and radioactive waste. Major concerns are closed landfills that were used to dispose of solid and hazardous laboratory waste. Several buildings and research reactors at ArgonneEast are contaminated with low levels of radiation and are undergoing or are scheduled for decontamination and decommissioning.

During 1994, a solid waste landfill was capped, a RCRA Facility Investigation Work Plan for the hazardous waste landfills was approved by State regulators, six other interim actions were completed, and characterization of several other inactive solid waste management areas continued with an Environmental Management budget of $\$ 42.2$ million. Argonne-East replaced eight leaking underground storage tanks and upgraded nine others, thereby preventing or reducing the spread of contamination to ground water. The Laboratory also completed the Phase II characterization report and 3 treatability studies for mixed waste regulated by the Toxic Substances Control Act, and removed about 3,600 dry tons of lime sludge from the water treatment facility.

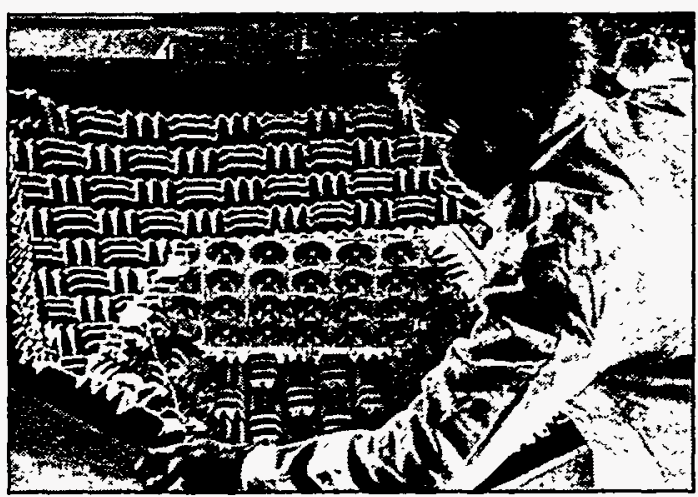

The Compact Sodar System was developed at Argonne National Laboratory to study the processes involved in acid rain.

During 1995 , with a budget of $\$ 38.7$ million, Argonne-East plans to complete design for Phase I of the rehabilitation of Building 306 and complete. rehabilitation of the waste management building. Other accomplishments scheduled for 1995 include completing the laboratory and sanitary sewer collection system rehabilitarion, installing monitoring wells to provide hydrological baseline information of ground water, and facilitating the proper closing of abandoned wells. All RCRA Facility Investigation field work will be completed for the capped landfill. The Map Tube interim action and five hot cells will be completed in 1995 . The decontamination and conversion to a mixed waste storage facility will also be completed in 1995.

Fermi National Accelerator Laboratory in Batavia, Illinois, operated for the Department's Energy Research office, explores the fundamental structure of matter using high-energy particle accelerators. Remediation spills at 22 transformer locations is required. Phase I of a RCRA Facility Investigation was completed in 1994 for 17 identified areas that may require remediation under the facility's RCRA permir, including an old tile field with some chromate contamination. Also, Fermi completed a 
draft environmental assessment and a conceptual design report for a new radioactive waste handling facility.

Fermi requested $\$ 5$ million in 1995 for ongoing waste management activities. Polychlorinated biphenyl remediation, start of phase II of the facility investigation, and Title II design work, and start of construction on the new radioactive waste handling building, which is expected to be completed in 1996.

Regular surveillance and moniroring for chemical contaminants will continue. The total budget for the site in 1994 was $\$ 3.5$ million.

Major environmental concerns include remediation of polychlorinated biphenyl spills; possible chromate contamination; and management of hazardous, radioactive, and toxic waste. There are 17 identified areas that may require remediation under the facility's RCRA permit. Fermilab completed a conceptual design for a new radioactive waste facility.

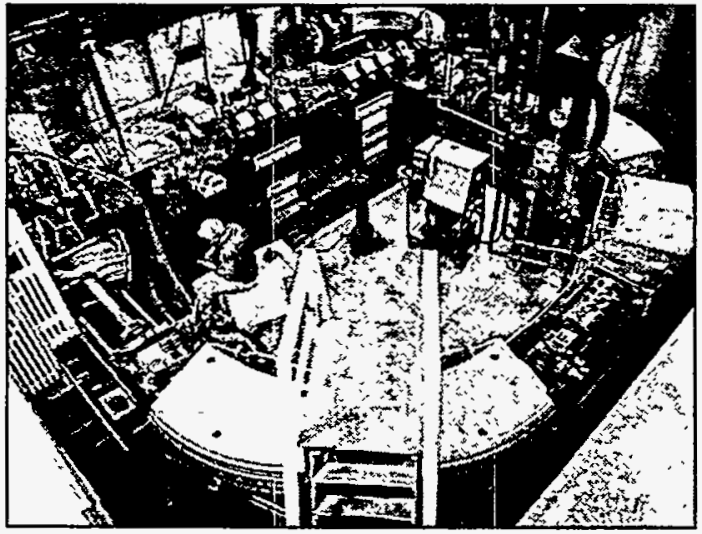

The Fermi Laboratory built the first proton therapy accelerator for treating cancer for Loma Linda University Medical Center. This device will help shorten the conventional treatment time on many cancerous tumors.

Fermi National Accelerator Laboratory will receive a budget of $\$ 5$ million in 1995 to continue polychlorinared biphenyl spill remediation activities and complete the first phase of the RCRA Facility Investigation report. Construction activities for the waste handling building will be completed during 1996 with a budget of $\$ 2.75$ million.

The remedial activities for Palos Forest Preserve Site A/Plot $\mathbf{M}$ in Cook County, the former Manhattan Engineer District site near Chicago, continued in 1994. Plot $M$ was the radioactive waste disposal area located close to Site A.
Currently, a surveillance and monitoring program analyzed samples for radioacrive and hazardous materials. The site publishes an annual report with these results.

\section{lowa}

Ames Laboratory occupies several buildings on the Iowa State University campus in Ames. Ames Laboratory conducts research in materials and chemicals sciences, and relared research in material reliability and nondestructive evaluation.

Ames had an Environmental Management budget of $\$ 8.9$ million for 1994 to conduct a variety of activities. Characterization of nine areas referred to as the "inactive waste sites" was completed. Approximarely 20 cubic yards of low-level radioactive soils was removed from one of the sites, the other eight sites required no remediation. Approximately 54,000 cubic feet of low-level contaminated soil, drums and other debris from a former chemical disposal site were removed and shipped to a commercial site in Utah in late February 1995. The budget for 1995 is $\$ 5$ million, which includes routine waste management activities.

All waste will be disposed ar an offsite area with no waste treatment onsite. For the Underground Storage Tank project, additional contaminated samples were obtained, indicating that excavation was not possible, and monitoring will continue in 1995. The remediation activities at the chemical disposal site will be completed in 1994, and monitoring wells will be installed to determine if any ground-water contamination exists. After completion of the source removal activities at the chemical disposal site, all wastes will be disposed, and monitoring wells will be installed to detect any residual contamination.

\section{Michigan}

The General Motors site in Michigan is a FUSRAP site. Information on FUSRAP sites begins on page 48. 


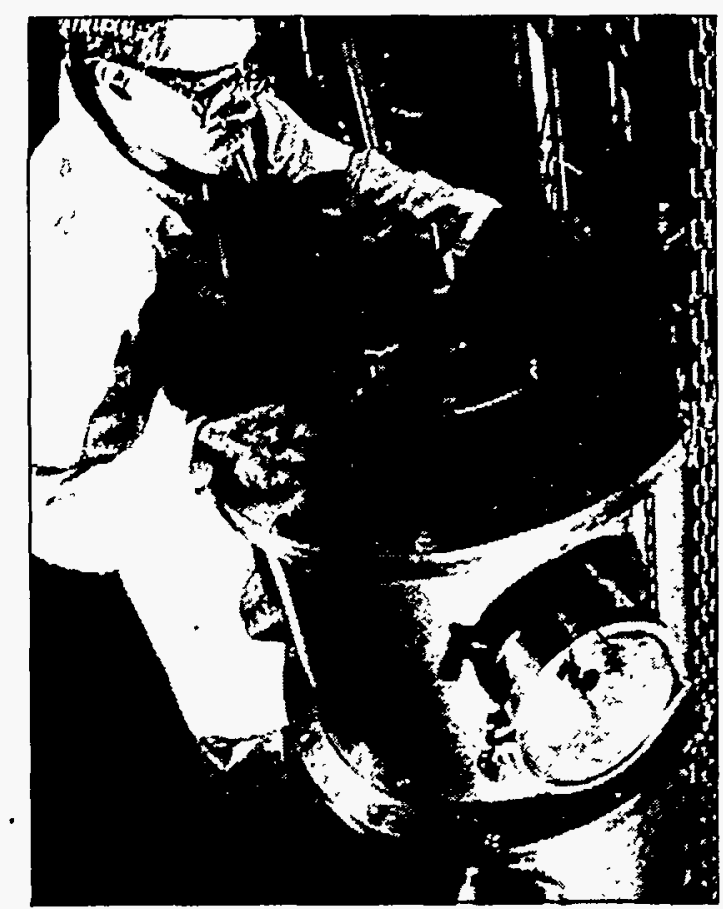

Ames Laboratory's innovative gas atomizer produces powders with enhanced conductivity, strength, and resistance to heat or corrosion.

\section{Missouri}

Missouri has four sites managed under FUSRAP. These sites, which include the St. Louis Downtown Site, St. Louis Airport Storage Site and St. Louis Airport Site Vicinity Property, and the Latty Avenue Properties, are described further on page 48.

In 1993, the Department shur down several facilities across the country and consolidated the production of nonnuclear components to the Kansas City Plant. The site is part of a 300 -acre Federal complex locared 12 miles south of downtown Kansas City, Missouri. Major environmental management activities include waste management, waste minimization and pollution prevention, technology development, and restoration of 41 potentially contaminated release sites. The Kansas Ciry Plant has no onsite disposal.

In 1994, a 2,900-linear-foot flood wall was constructed to protect the site's RCRA Storage Facility. The Kansas Ciry Plant also excavated nearly 14,000 cubic yards of polychlorinated biphenyl-contaminated soil from the Abandoned Indian Creek Outfall. Discussions continued with the Missouri Department of Natural Resources on future plans for the treatment and disposal of the small quantity of mixed waste at the Kansas City Plant. All activities were completed with an Environmental Management budget of $\$ 12.6$ million.

Modification of an existing outside covered storage area will be included in the 1995 Environmental Management budget of $\$ 11.2$ million. The final site treatment plan will also be completed in 1995. Studies to support remediation decisions of severat areas will continue and interim remediation action of one area will be completed.

In 1996, several areas will begin planning for final remediation actions and remediation will begin at one area. Bulk storage tanks will be upgraded, and a decision will be made on remediation options for five environmental restoration subprojects. Innovative technologies for in situ ground water treatment will be developed. The Kansas City Plant will request a 1996 Environmental Management budget of \$12.3 million.

During the second World War, the Weldon Spring site was used as a military ordnance plant. In the 1950's and 1960's, the Aromic Energy Commission utilized the site for processing uranium ore, abandoning the site in 1966. Primary environmental concerns at the site include a 9-acre quarry with radiologically contaminated soil, rubble, and water, and a 217 -acre chemical plant site with contaminated waste pits, process buildings, and contaminated soil and water migrating to offsite vicinity properties.

During 1994 , with a budget of $\$ 39.7$ million, Weldon Spring continued the successful treatment and discharge of contaminated water from the quarry and chemical plant as well as the removal of bulk waste from the quarry. Sixteen chemical plant buildings were dismantled, and construction of the pilot Chemical Stabilization/Solidification plant began. Work continues on the Remedial Investigation/Feasibility Study-Environmental Impact Statement for the quarry residual contamination and the site ground water.

In 1995 , with a budget of $\$ 53.1$ million, these efforts will continue. Dismantlement of all chemical plant buildings and construction of the pilor Chemical Stabilization/Solidification plant will be completed. In addition, systems development to support onsite disposal facility 
construction and operations, including a soil borrow area, is scheduled to begin. By 1996, the removal of Quarry bulk waste will be completed and the removal of building foundations will begin. The budget request for 1996 is $\$ 67.5$ million.

\section{Nebraska}

The Hallam Nuclear Power Facility near Lincoln, Nebraska, was built and operated as a demonstration project by the Atomic Energy Commission between 1962 and 1966. The facility contains entombed components from a thermal sodium-cooled graphite-moderated nuclear reactor.

Between 1967 and 1969, the facility was dismantled and placed in a safe storage condition. Surveillance and maintenance continues at Hallam to ensure that no radioactivity is being released from the facility. Semi-annual ground-water sampling and analysis and radiological survey of the entombed reactor are also conducted. Assessment reports detailing the sampling and analysis at the site are published annually. The funding for 1995 is $\$ 21,000$.

\section{Ohio}

In addition to the Fernald Environmental Management Project, Ohio has 12 sires in various stages of remediation. Seven of these sites are under the FUSRAP program; discussion begins on page 48.

The Battelle Columbus Laboratories Decommissioning Project located in Columbus, Ohio, performed research and development work at its facilities for the Department of Energy predecessors. The buildings are privately owned by Battelle, and the facility retains an active Nuclear Regulatory Commission license for radioacrive materials. The Battelle Columbus Laboratories Decommissioning Project was established to decontaminate and decommission Battelle facilities. The facilities within the Battelle Columbus project consist of 15 buildings, or portions thereof, and are located at Bartelle

Memorial Institute's Battelle Columbus Laboratories King Avenue site in Columbus and the West Jefferson site near Columbus, Ohio. Decontaminating and decommissioning of four buildings was completed prior to 1994, and work at one additional building was completed in 1994. The budget for Battelle Columbus is $\$ 17.5$ million.

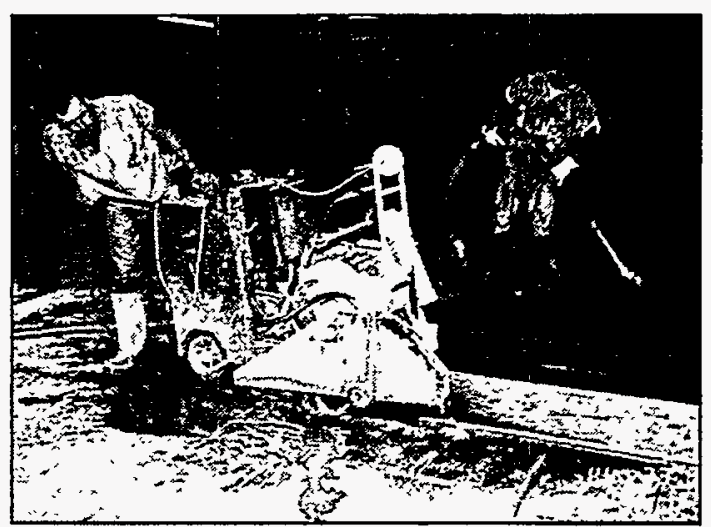

Workers remove concrete floor block from the basement of $a$ building being decontaminated and decommissioned at Battelle Columbus Laboratory.

In 1995 , with a budget of $\$ 19.1$ million, decontamination and decommissioning of 2 additional buildings and the King Avenue site will complete the decontamination and .

decommissioning of two additional buildings. All buildings are scheduled for completion by 2000 and will be released for use without radiological restrictions. Battelle's 1996 budget is estimated at $\$ 20.7$ million.

- The Mound Plant, located in Miamisburg, Ohio, was built in the 1940's to support research and development and production activities for the Department of Energy's weapons and energy programs. It occupies 306 acres of land in southwestern Ohio. Weapons production support ended in 1994, when activities across the country were consolidated at the Kansas Ciry Plant in Missouri. The Mound Plant will continue to support the Department's nuclear energy programs.

In 1994, \$41.6 million was appropriated for the site's environmental management activities.In 1994, a CERCLA remedial investigation/feasibility study was completed of ground-water contamination by volatile organic compounds that resulted from past waste management practices. The site also began planning for removal of plutonium-contaminated sediments resulting from a previous break in a waste transfer line. Several 
expedited remedial acrions were iniriared in 1994, including a project to use bioremediation to treat contaminated soil. Decontamination and decommissioning accomplishments in 1994 include the removal of a contaminated underground waste transfer line, removal and dismantlement of most of the building where plutonium ${ }^{238}$ was formerly processed, and sampling of the building that used to store thorium.

The 1995 Environmental Management budget for Mound is esrimated ar $\$ 43.0$ million. Planned activities include developing the first CERCLA Record of Decision for remediation of groundwater contamination and commencement of design activities, site-wide remedial investigation field work in six areas, and continued planning for removal of the plutonium-contaminated sediments. Other planned activities include the dismantlement of the former plutonium processing building and several characterization activities.

Treatment, storage, and disposal of hazardous waste at the site will continue, in addition to the disposal of Mound's low-level waste. An additional 22 buildings are scheduled to be shutdown this year. Funding in 1996 for the Environmental Management program is planned at $\$ 110.3$ million.

The Piqua Nuclear Power Facility in Ohio contains entombed nuclear reactor components from a reactor that was built and operated for a demonstration project by the Atomic Energy Commission between 1963 and 1966. The facility was decommissioned and dismantled between 1967 and 1969. Current site activities consist of an environmental monitoring program to ensure radioisotopes are not migrating from the entombment structure into the surrounding environment. This monitoring is documented in an annual report. Annual evaluation and assessment of the facility identifying replacement of roof, dernolition of exhaust stack, upgrade of fire protection sprinkler system, and replacement of failing carhodic protection system were completed in 1994 at a cost of $\$ 40,000$. The 1995 budget is $\$ 12,000$ for routine surveillance and maintenance activities.

The Portsmouth Gaseous Diffusion Plant, located on 3,700 acres in Portsmouth, separates uranium isotopes to produce enriched uranium used for fuel in commercial nuclear powerplants. Portsmouth was leased in July 1993 to a newly formed government corporation known as the United States Enrichment Corporation, but the Department of Energy is responsible for remediation of pre-existing conditions.

Environmental problems, which include contamination of the aquifer beneath the site at Portsmouth, are divided into four quadrants for investigational purposes. The RCRA Facility Investigation on the four quadrants continued in 1994. Portsmouth completed three RCRA closures that returned selected areas to operational service and the interim action on a well and landfill. These and other activities were completed with a budget of $\$ 70.4$ million.

The budget of $\$ 59.8$ million in 1995 will support the completion of three RCRA Facility Investigations, the remediation of storage tanks, and the completion of the design of the solid waste landfill. Two RCRA closures and one interim action will also be execured. During 1996, Portsmouth plans to complete RCRA Facility Investigations on all four quadrants and complete three RCRA closures. These activities and others will be completed with a budget of $\$ 86$.I million.

The Reactive Metals, Inc. Decommissioning Project located in Ashrabula, Ohio, originally subcontracted with Department of Energy contractors to extrude uranium for use in various nuclear applications. The environmental restoration mission at the site is to decontaminate and decommission the site for unrestricted use. Reactive Metals, Inc. is a potentially responsible party to the Fields Brook Superfund site, which is adjacent to the extrusion plant. The Department of Justice will negotiate on behalf of the Department of Energy, with the Environmental Protection Agency and Reactive Metals, Inc., to reach a settlement on the Fields Brook liability.

Activities completed in 1994, with a budget of $\$ 12.5$ million, include the safery evaluation for storage, transportation, and disposal of uranium oxides; completion of characterization of three filter buildings; and completion of characterization for several buildings. Waste shipments to the Nevada Test Site will continue to make onsite storage space available for offsite soils, and shipments of waste to offsite facilities will also occur.

In 1995 , with a budger of $\$ 6.5$ million, Reactive Metals, Inc. will submit the final Corrective Measures Study to the Environmental 


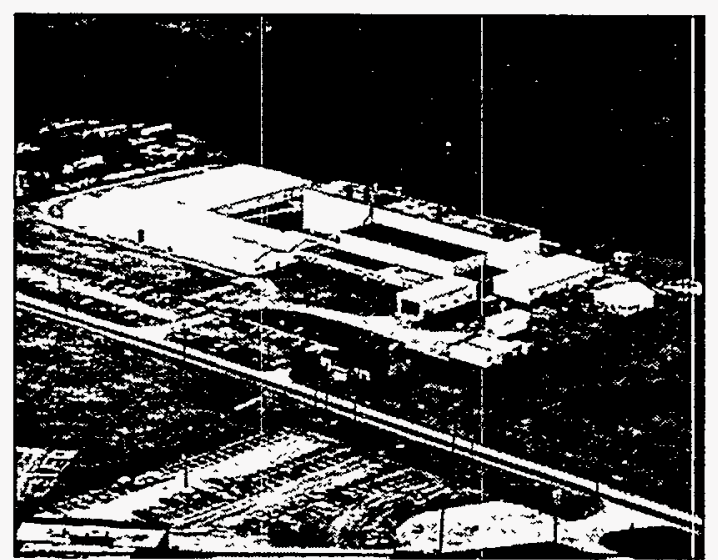

The Reactive Metals, Inc. Decommissioning Project plant in Ashtabula, Ohio.

Protection Agency for review and the revised Site Characterization Plan to the Nuclear Regulatory Commission for review, and will complete characterization of two buildings.

\section{FUSRAP and UMTRA Sites}

There are no UMTRA sites and 16 FUSRAP sites in the Central region. The University of Chicago and the National Guard Armory, both in the State of
Illinois, completed environmental management activities prior to 1993. Environmental Management activity at the Granite City Steel site in Illinois was completed in 1994.

Remedial action is underway at the Alba Craft site in Oxford, Ohio, and most of the work was complered by December 1994. A Record of Decision is expected to be issued in 1996 for the St. Louis site in Missouri. This site includes the St. Louis Downtown Site, the St. Louis Airport Storage Site, the St. Louis Airport Site Vicinity Property, and the Latty Avenue Properties.

Remediation activities at the General Motors site in Adrian, Michigan, are expected to begin in 1995.

Limited characterization has been conducted at several sites under FUSRAP. These include the Madison sire in Illinois, and the B\&T Metals, Painesville, Baker Brothers, Luckey, Herring-HallMarvin Safe Co., and Associated Aircraft Tool and Manufacturing sites in Ohio. 

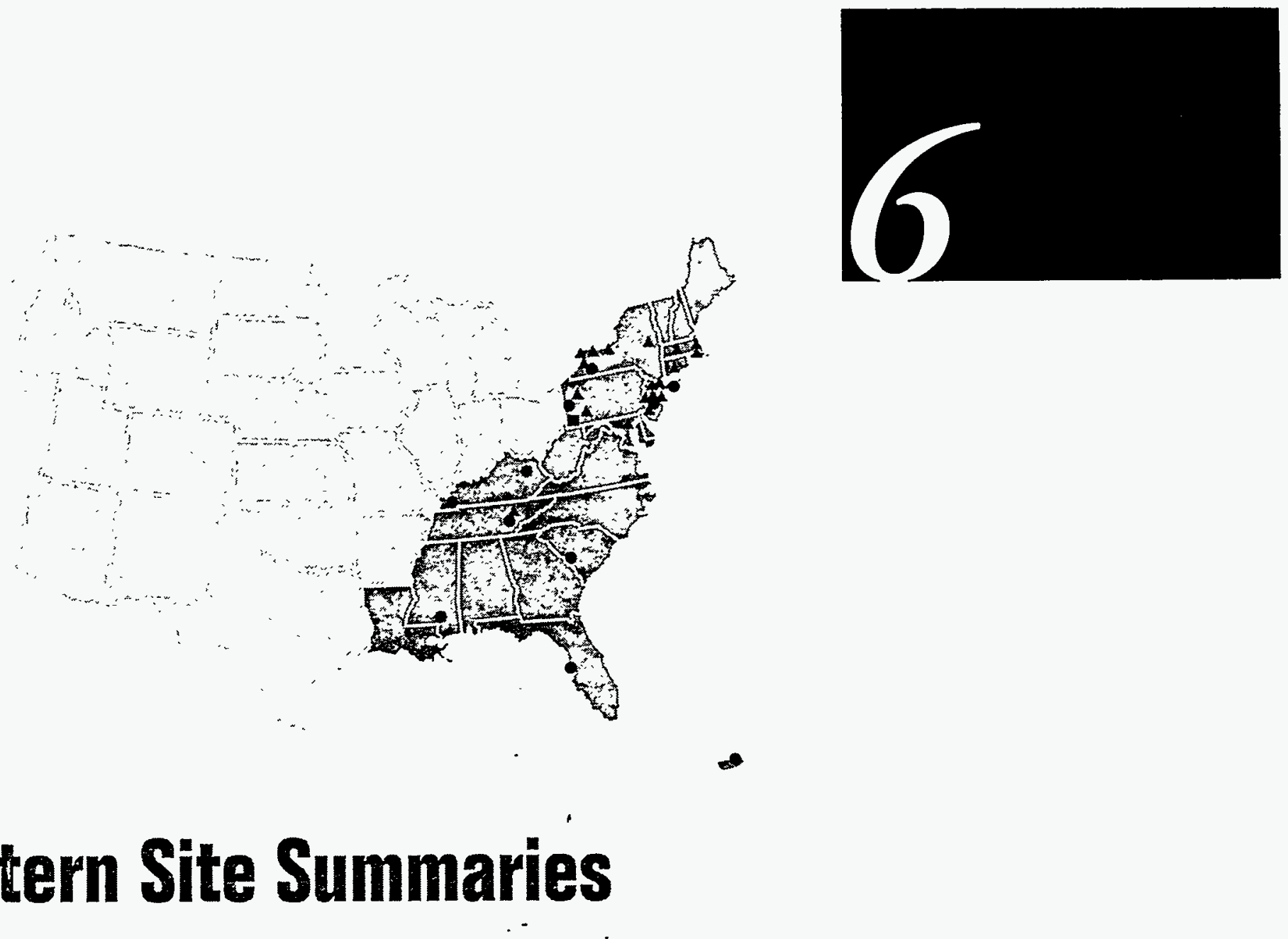

\section{Eastern Site Summaries}

Environmental management activities are currently taking place in Connecticut, Florida, Kentucky, Maryland, Massachusetts, Mississippi, New Jersey, New York, Pennsylvania, Puerto Rico, South Carolina, and Tennessee. These States make up the Eastern region for the purposes of this report. The major sites in the region are the Oak Ridge Reservation in Tennessee and the Savannah River Site in South Carolina. General performance and funding information are included in this section; more specific information can be found in the Performance and Funding Data section beginning on page 61 .

\section{Oak Ridge Reservation, Tennessee}

The Oak Ridge Reservation consists of three separate sites: a national laboratory, a manufacturing and developmental engineering plant, and a former gaseous diffusion plant (see the site map on the next page). While each site has distinct missions for the Department, cleanup of the three sites and gaseous diffusion plants in Paducah, Kentucky, and Portsmouth, Ohio, are all managed as one program. The Oak Ridge Reservation's total budget, including management of Formerly Utilized Sites Remedial Action Program (FUSRAP) sites (see discussion on page 6) nationwide for 1994 was $\$ 675.6$ million. Oak Ridge completed, or was on schedule to complete, approximately 78 percent of its compliance agreement milestones in 1994.

The Oak Ridge National Laboratory covers approximarely 2,900 acres in Melton and Bethel Valleys, 10 miles southwest of the City of Oak Ridge. The Laboratory's mission is to conduct applied research and development in support of the Department's programs in energy technologies, and to perform basic research in selected areas of the physical and life sciences. Past research, development, and waste management activities at the Laboratory have produced a number of areas contaminated with low-level and/or hazardous chemical waste that will require remediation.

The Y-12 Plant was built in the early 1940's to produce enriched uranium by electromagentic separation for the Nation's first nuclear weapons during World War II. A few years later, this process was rendered obsolete by the gaseous diffusion process, and the plant became the enriched uranium weapons 




Figure 7. The Oak Ridgc Reservation.

\section{Oak Ridge 1994}

Performance

In 1994,0ak Ridge was 3 percent behind schedule and 3 percent over cost. The waste management portion indicates that the program is on schedule while running 8 percent over cost. component facility. Since then, the Y-12 Plant has become the center for the handling, processing, storage, and disassembly of all uranium materials and components. With the end of the Cold War, the Plant's mission has evolved to dismantling nuclear weapons components and serving as the primary enriched uranium repository for the United States.

The K-25 Site occupies a 1,700-acre area adjacent to the Clinch River, approximately 13 miles west of Oak Ridge. Originally built to enrich uranium hexafluoride for defense programs, a majority of the 125 major buildings on the site are now inactive since production ceased in 1987 . The site's mission has changed primarily to environmental management. The $\mathrm{K}-25$ Site is the principal waste storage facility on the Oak Ridge Reservation and houses the Toxic Substance Control Act Incinerator and the Center for Environmental Technology and Waste Management.

Also in Oak Ridge, but not on the Oak Ridge Reservation, are several sites associated with operations at the three facilities that require , remediation. These include the Oak Ridge Institute for Science and Education, the Clinch River/Watts Bar Lake, Lower East Fork Poplar Creek, and other small privately owned sites in the area.

In May 1993, the Center for Environmental Technology and Waste Management officially opened at the K-25 Site. The Center accelerates the development, demonstration, and commercialization of restoration and waste management technologies for the Department, other Federal agencies, and the commercial sector to help solve the Nation's waste management problems. The Center also provides private firms and other partners with quick and easy access to the site and many of its unique facilities and laboratories.

An Office of Nuclear Material and Facilicies Stabilization was established in 1994 at Oak Ridge to coordinate and oversee the orderly deactivation and stabilization of surplus contaminated facilities and functionally related uncontaminated ancillary facilities from other Department of Energy programs into Environmental Management. Until the facilities undergo ultimate decontamination and decommissioning, or are transferred to another Department program or Federal agency, the Office of Nuclear Material and Facilities Stabilization 
manages all landlord, surveillance, and maintenance activities. It is also responsible for optimizing the costs and benefits of deactivation and ongoing surveillance and maintenance. The objective is to reduce surveillance and maintenance costs as quickly as possible, while preserving future options for reusing selected facilities. The Departmental office operating the facility and Environmental Management must agree on roles, responsibilities, and funding before the facility is transferred to the Office of Nuclear Material and Facilities Stabilization.

In 1994, 15 facilities formerly used for isotope production at the Laboratory were accepted by the Office of Facilities Stabilization. Activities have focused on correcting deficiencies, developing a deactivation work plan, removing cobalt from the facilities and placing it in retrievable storage, inventorying, and packaging and shipping the thermoluminescent lights to a vendor for recycling. Approximately 140 more facilities have been declared surplus at the Laboratory and the $\mathrm{Y}-12$ Plant.

In 1994, Oak Ridge completed four assessments and five interim actions. They included assessments for three pilot projects. These projects are an example of the Department's contract reform initiative, and will result in a reduction of the cost and schedule of environmental restoration activities. The interim actions included the removal of material from several offsite locations. Remedial actions at 15 sites and decontamination and decommissioning actions in 4 areas were also completed, including the Electrochemical Machining Area in the 9201-4 facility at Y-12 and the decontamination and decommissioning of electrical components containing polychlorinated biphenyls at the $\mathrm{K}-25$ Site.

In 1994, 140 treatment, storage, and disposal facilities operated in compliance with State and Federal regulations; 125 million gallons of wastewater were treated; a waste storage inventory of 2.1 million cubic feet was maintained; and 1.1 million cubic feet of sanitary waste was disposed. At the Laboratory, 50,000 gallons of radioactive liquid waste were solidified and prepared for shipment to the Nevada Test Site for disposal. At the Toxic Substances Control Act incinerator, 5.7 million pounds of mixed waste liquids were treated, exceeding the goals set under the site's Federal Facility Compliance Agreement. A new landfill for sanitary and industrial waste, which has enough capacity to be used into the next century, opened in 1994. Contracts were established with a private company to treat the Department's mixed waste sludges and radioactively-contaminated soils, recycle contaminated scrap metal, and reduce lowlevel waste volumes.

In 1994, Oak Ridge worked with a private company to complete a technology demonstration that urilized ultraviolet peroxidation to destroy organic contaminants in ground water. The demonstration, completed below the estimated cost, used the Direct Sampling Ion Trap Mass Spectrometer, developed at the Oak Ridge National Laboratory to continuously monitor the process. Several other technology development projects exploring the use of biotechnology to remediate soil and ground-water contamination issues continued at Oak Ridge. The technologies involve the use of natural microorganisms to degrade or remove contaminants from soil and water. Bioremediation is inexpensive and uses natural processes, making ir more cost-effective than other remediation methods.

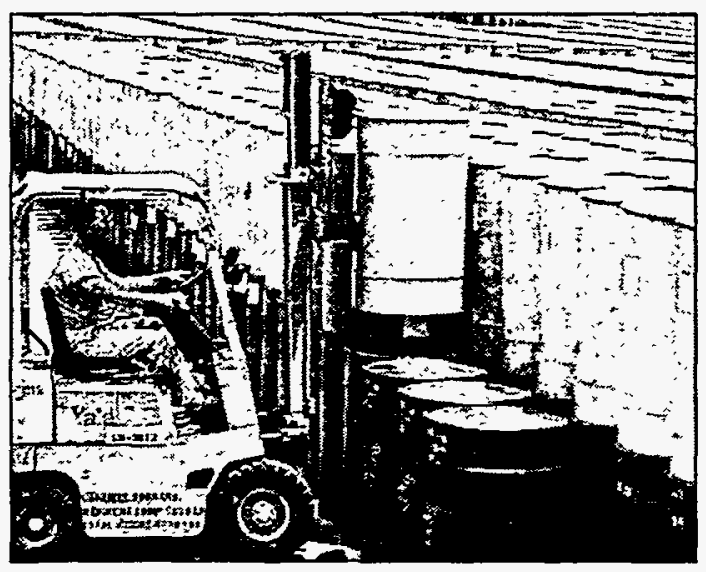

Solidified waste stored in metal drums at the Oak Ridge K25 Site.

With a 1995 Environmental Management budget of $\$ 684.7$ million, the Oak Ridge Reservation will continue to move forward with site characterization and remedial activities, disposition of characterized waste, and technology development. Nine remediation and five decontamination and decommissioning actions will be completed, including the closure of the holding pond and the retention basin at K-25 and the remediation of seeps at a Laboratory area. Also, 10 
In 1995, Oak Ridge Will Use the Following Goals to Measure Its Performance:

Perform 19 assessments, 9 interim actions, 7 final remediations, and 3 decontamination and decommissioning activities.
In situ bioremediation Integrated Demonstration, completed in 1994, was one of Environmental Management's most significant development successes, representing a breakthrough in the field of bioremediation in general. Under this project, in situ bioremediation of ground water contaminated with trichloroethylene was demonstrated. Injection of methane and air plus nutrients, using horizontal wells, enhanced the growth and degradation activity of indigenous trichloroethylenedegrading microorganisms. Measurements taken at the surface revealed increased levels of carbon dioxide, water, and chloride, indicating complete biodegradation of the trichloroethylene. This project led to the development of many new technologies being transferred to industry. assessments of remedial action and decontamination and decommissioning sites will be completed. The Pond Waste Management Project will complete the repackaging of 31,000 deteriorated drums containing sludge from the ponds and their subsequent placement into RCRAcompliant storage. Private sector treatment of sludges will be conducted and evaluated.

The Toxic Substance Control Act Incinerator will complete testing on combustible solid waste for renewal of the Air Permit and will meer treatment goals outlined in the Federal Facility Compliance Agreement. Another requirement of the Act is to generate a plan for treatment and/or disposal of accumulated waste on the reservation. Two contracts are scheduled to be awarded for proof-of-process treatment and disposal of mixed low-level waste sludges and soils. The final plan will be submitted in April 1995 to the regulators for approval. Shipments of solid low-level waste to the Nevada Test Site are also scheduled. Four projects will be completed to provide additional storage and treatment capacity. The demonstration phase of the Out-of-Tank Evaporator project will be initiated on waste to evaluate the potential for improved volume reduction at the Melton Valley Storage Tanks. Following the demonstration, the זechnology will be implemented without delay. Deactivation activities will continue on the isotope facilities at the Laboratory, and program planning will begin for additional facilities scheduled to be transferred to the Office of Facilities Stabilization in 1996.

In 1996, six remedial action and decontamination and decommissioning assessments, two remedial actions, and three decontamination and decommissioning actions are scheduled to be completed. These include the completion of projects to reduce the level of mercury leaving buildings at the Y-12 Plant, to reduce discharges to East Fork Poplar Creek, to demolish the Powerhouse at the $\mathrm{K}-25$ site, to decontaminate and decommission the waste evaporator facility at the Laboratory. Also in 1996, Oak Ridge will initiate implementation of the requirements of the Site Treatment Plan. The first phase of construction to increase capacity at the Melton Valley Storage Tanks by 450,000 gallons of low-level waste will be completed and placed in operation. The vitrification and thermal desorption bench-scale demonstrations of mercury and volatile organic contaminants removal from mixed waste will also be completed.

\section{Savannah River Site, South Carolina}

The Savannah River Site, located near Aiken, South Carolina, was constructed to produce tritium and plutonium for nuclear weapons on its 310-square mile area. With the end of the Cold War, Savannah River Site is changing from a national defense to environmental restoration and economic development mission, although it continues to serve vital nuclear weapon missions. Environmental restoration field work was performed on over 50 waste sites in 1994, while maintaining the highest safety record within the Department of Energy complex. A close working relationship with regulators, coupled with productivity improvements in the work performed, has increased remediation and restoration work in the field significantly over the past year. Project management activities have been streamlined, resulting in performance at 14 percent less than originally estimated, a savings of $\$ 2$ million per year that can be applied to field remediation.

With a 1994 budget of $\$ 763.9$ million, Savannah River Site operations are evolving from high-level waste storage and evaporation to trearment through the use of vitrification. Vitrified waste produced at the Defense Waste Processing Facility will be disposed of in a geological repository. The first canister of simulated glass at the facility was filled to test the process in 1994. Startup testing will continue in support of beginning operation with radioactive materials in December 1995. Operation of two evaporator systems to reduce the volume of high-level waste resumed in 1994. A site-wide waste management Environmental Impact Statement to assess an approach to managing all waste generated from ongoing operations, environmental restoration, and decontamination and decommissioning at the site is now being prepared.

Savannah River Site continues to make significant progress in using and developing new technologies for its environmental management 


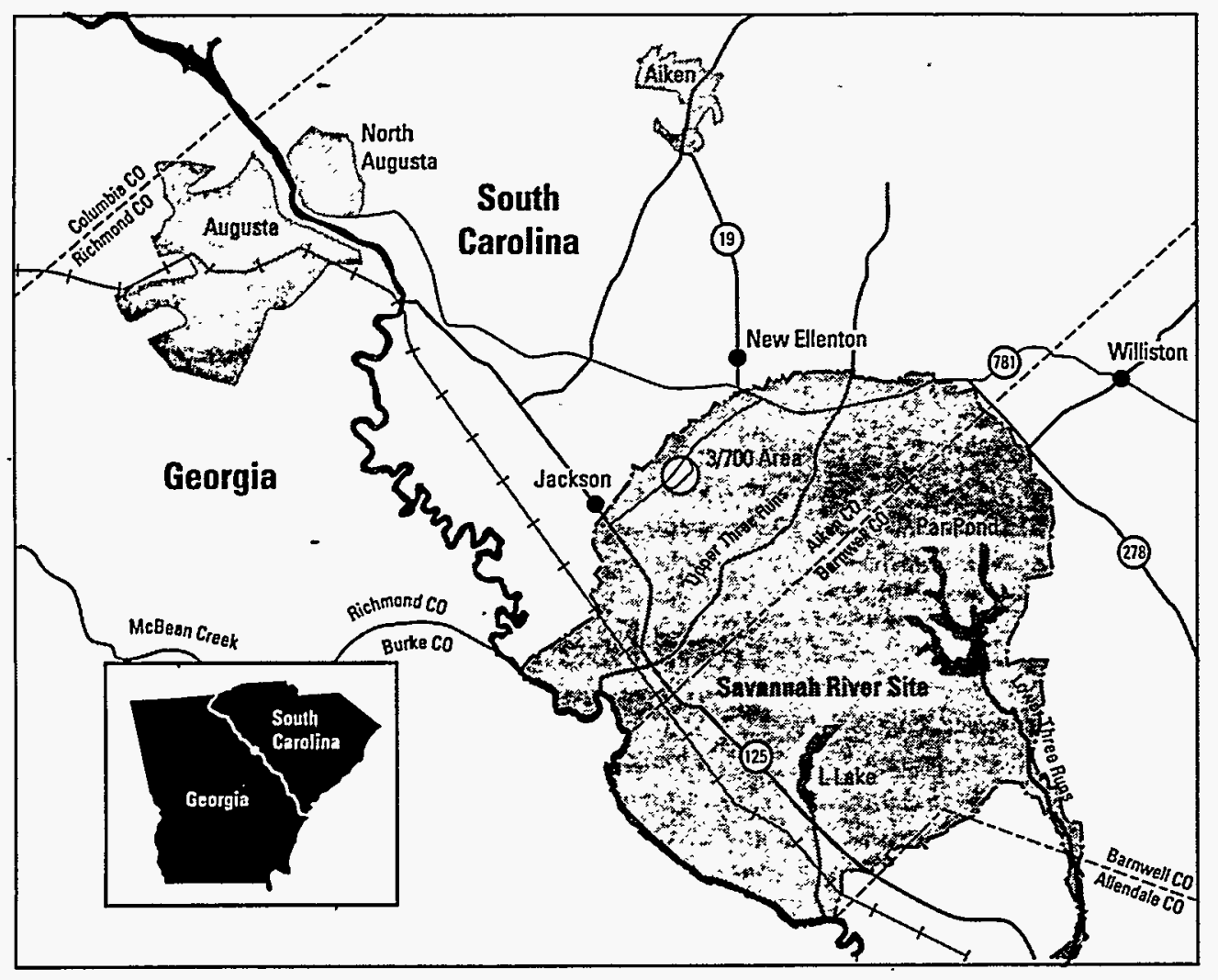

Figure 8. The Savannah River Site.

activities. Recent technology demonstrations include the Bentonite Mat, SoilSaw, rotosonic drilling, and in situ bioremediarion. The Beneficial Reuse Program will recycle slightly radioactive stainless steel by fabricating it into waste storage containers. More than 25 ideas introduced at the Vendors' Forum, where the commercial public was invited to propose solutions to the site's waste management disposal needs, are being applied at the site, and other new technologies are anticipated to be developed as a result of the additional forums. A third air stripper will be added to augment the 2 billion gallons of ground water and 313,000 pounds of solvents treated by 2 air strippers in . 1994. Research conducted under the Minimum Additive Waste Stabilization was utilized to address low-level mixed waste remediation at the site. A contract has been awarded to a private industry partner for this work.

Thirty-five interim actions initiated in 1994 were completed. Field characterization work was started at 14 waste sites in 1994. A total of 659 contaminated buildings have been identified as possible candidates for decontamination and decommissioning. In 1994, the Savannah River Site Citizen Advisory Board was formed. The Board reviews programs and plans at their inception to ensure public opinion will be incorporated into decisions at the site. The site reduced its generation of solid low-level waste by 33,000 cubic feet in 1993 and 114,000 cubic feet in 1994. The site will reduce all other solid waste streams by 10 percent in 1995 . All site organizations will be challenged to incorporate a pollution prevention program with an even broader scope. As a cost reduction measure, the new sanitary landfill project was cancelled in lieu of shipping sanitary waste to an existing commercial disposal facility offsite. The site will continue construction of the Consolidated Incineration Facility that was designed to treat hazardous, mixed, and low-level radioactive waste. Pending the outcome of the Savannah River Site Waste Management Environmental Impact Statement, it will be determined if low-level radioactive waste will be treared. The facility is scheduled to be operational in 1996.
Savannah River Will Use the Following Goals to Measure Its Performance in 1995:

Perform 15 assessments and complete 16 interim reports and 3 final remediations. 


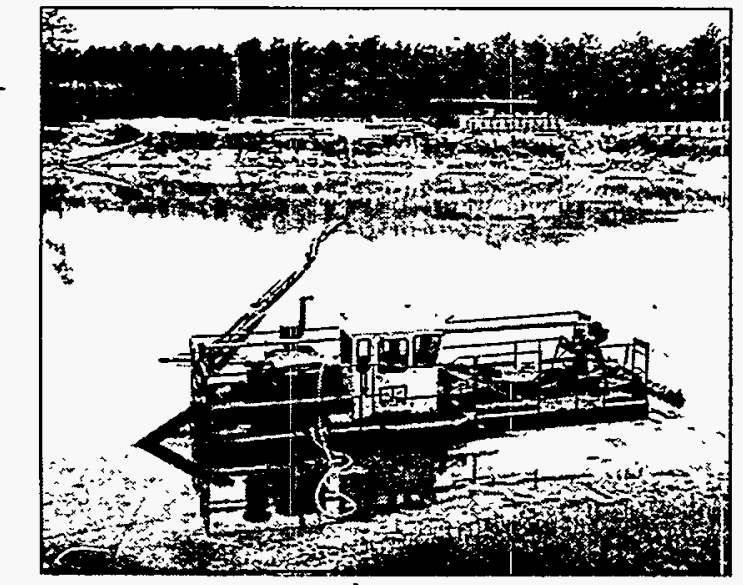

The $M$-Area basin, which received waste from the fuel and target fabrication facilities at the Savannah River Site, was dredged and closed.

Characterization of waste sites representing more than 80 percent of the estimated risk associared with these sites will be underway by the end of 1995. Four 30,000-gallon double-walled underground storage tanks with leak detection, leak collection, overfill protection, liquid waste agitators, and air monitors will be constructed. $A$ study to reevaluate the design of a subsurface concrete vault divided into 12 separate cells with more than 1.2 million cubic feet of storage to ensure it is a cost-effective storage option is . expected to be complete in 1995. Planning is in progress to retrieve transuranic waste drums from bermed storage beginning in 1997 . Work is currently underway to remove rainwater from the transuranic waste drums. Savannah River Sire has been budgeted $\$ 711.1$ million for planned activities in 1995.

The Environmental Restoration program will continue field work at more than 50 sites in 1995 and 1996. The Site Treatment Plan, to define the site's mixed waste streams and the best treatment option for each, will be finalized and submitted to the State for approval in 1995. Savannah River Site will continue ground-water remediation and site characterization activities at contaminated sites. Interim and final remedial actions will be initiated at several waste sires.

In 1996, Environmental Management has a requested budger of $\$ 1.34$ billion, a doubling due in part to Environmental Management taking over responsibilities of Defense Program facilities. With this budget request operation of the Consolidated
Incineration Facility and New Solvent Storage Tanks will begin, and the New Waste Transfer Facility will startup. Savannah River Sire will also begin closure of the Low-Level Radioactive Waste Disposal Facility.

\section{Connecticut}

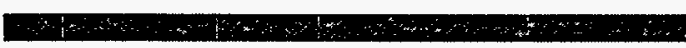

The Seymour Specialty Wire site and the Combustion Engineering Site (CE Site) are a part of the FUSRAP program. Discussion on FUSRAP and UMTRA sites begin on page 58 .

\section{Florida}

The Pinellas Plant is locared in Pinellas County, Florida, near the City of St. Petersburg. It produced high-technology nuclear components that require strict control of materials and processes in an ultraclean environment. The plant had been an essential part of the Nation's nuclear weapons complex, but production of weapons-related components was discontinued on September 30, 1994. The site is now investigating which producr lines could be converted to commercial and nonmilitary applications.

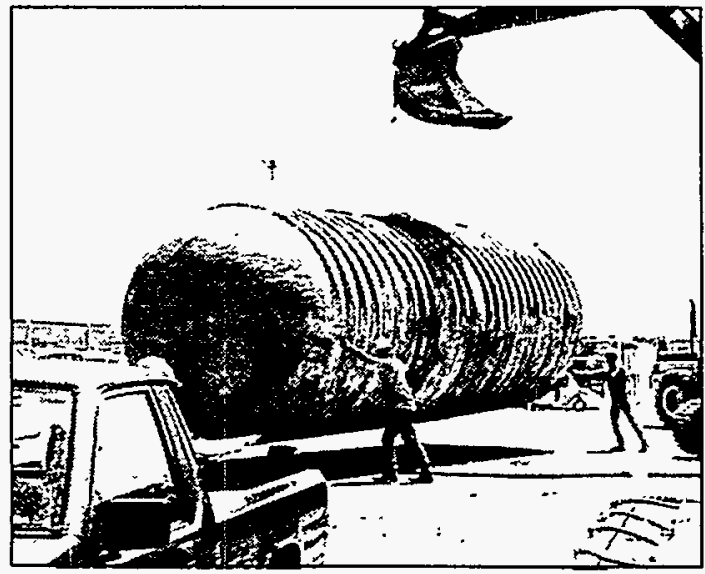

An underground diesel storage tank is removed at the Pinellas Plant.

The current mission is to develop, implement, and maintain a comprehensive Environmental Management program to expeditiously and costeffectively remediate the Pinellas Plant for transfer 
to privare economic development and commercial use. In 1994, temporary storage of both low-level and hazardous waste was required prior to shipping the waste offsite for disposal. The 1994

Environmental Management budget was $\$ 7.2$ million. The plant will continue disposing of accumulated chemicals and generated waste and other activities to safely shurdown the sire in 1995 and 1996. Per discussions with the State of Florida, the Pinellas Plant submitted a Final Starus Report and Contingency Plan in December 1994 in lieu of a Final Site Treatment Plan for mixed waste because there is currently no mixed waste onsite. The Pinellas Plant will continue its research in mixed waste treatment. The Environmental Management budget for 1995 is $\$ 7.7$ million and $\$ 52.6$ million for 1996. These increases are due to Environmental Management taking over landlord responsibilities. In 1995, an interim remediation action will be implemented at one site area, and plans will be completed for final remediation actions at two site areas.

The 4.5 Acre Site, located adjacent to the Pinellas Plant, was used as a waste disposal area for drums containing resins and solvents. The surface aquifer in the area is contaminated with residual volatile organic compounds as a result of this practice. Approval of the final remedial action plan is expected in early 1995, after the completion of negotiations of a consent agreement. Interim ground-water remediation has been underway since 1991.

The Pinellas Plant may have sold as much as 3,605 gallons of waste oil to the Peak Oil Petroleum Refining Plant in Largo, Florida, in 1978 and 1979 for recycling beneficial fuel. Peak Oil used a rerefining process to purify used oils and lubrications fluids. Mismanagement by the Peak Oil facility of waste oil and hazardous waste resulted in extensive soil and ground-water contamination. Pinellas was consequently identified as a Potentially Responsible Party, thereby making the Department of Energy partially responsible for remediation.

\section{Kentucky}

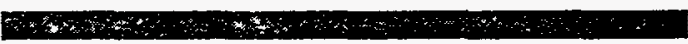

The Maxey Flats Disposal Site is a low-level radioactive waste disposal site located in northeast Kentucky, approximarely 17 miles south of Flemingsburg.

The Department of Energy is one of approximately 800 identified potentially responsible parties. The Department's share of the financial liability for remedial actions and related tasks is about 40 percent. The Record of Decision for the site was signed in 1991. Consent Decree negotiations are nearly complete, and remedial design and action will commence once the agreement is approved. The total Department's costs are estimated to be $\$ 26.4$ million from the present until the project is complete in 2000.

The Paducah Gaseous Diffusion Plant, located on 750 acres in Paducah, separates uranium isotopes to produce enriched uranium used as fuel in commercial nuclear powerplants. Like the Portsmouth Gaseous Diffusion Plant in Portsmouth, Ohio (see page 47), the plant was leased in July 1993 to a newly-formed government corporation known as the United States Enrichment Corporation. The Department of Energy is still responsible for cleaning up the onsite and offsite soil and ground-water contamination, including uranium, polychlorinated-biphenyls, rechnetium, and trichloroethylene.

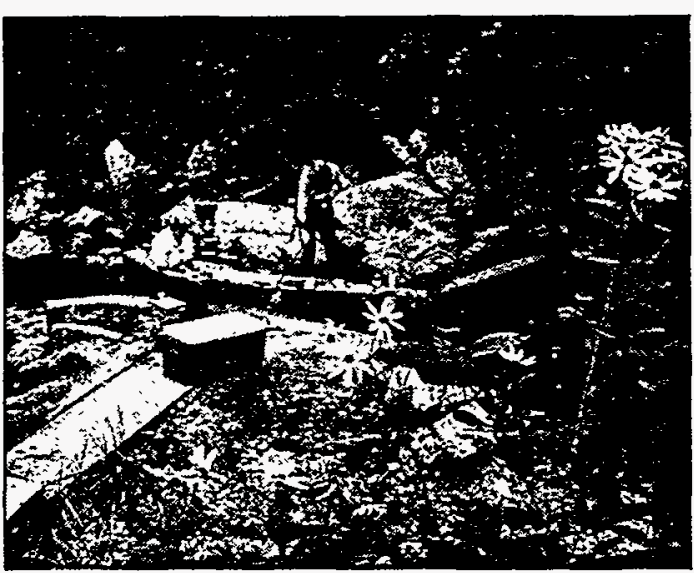

Ground-water sampling being conducted at the Paducah Gaseous Diffusion Plant.

Paducah spent $\$ 36.5$ million in 1994 on various environmental restoration activities. In June 1994, the site was placed on the National 
Priorities List, and an Interagency Agreement with the Environmental Protection Agency and

Kentucky is under negotiation. A RCRA Corrective Measure and RCRA Closure associated with underground storage tanks were completed in addition to the construction of the support facilities for the remedial investigations. In 1995 , with a budget of $\$ 53.5$ million, the northwest plume interim action construction will be completed and operations initiated. Design and construction of a diversion ditch will be completed. The Records of Decision for the norrheast plume and an onsite sanitary landfill will be developed. Both will be completed in an effort to prevent further releases of contaminants into the ditch and stop offsize migration of contaminants. In 1996, with a budget of $\$ 56$ million, remedial investigations will continue and the design and construction activities on the northeast plume and onsite landfill will begin.

\section{Maryland}

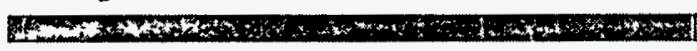

The W.R. Grace \& Company site is the only site in Maryland and is managed under the FUSRAP program. Discussion of this site can be found on page 59.

\section{Massachusetts}

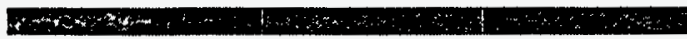

Massachusetts has three sites managed under the FUSRAP program: Shpack Landfill, Ventron, and Chapman Valve. Discussion of these sites can be found on page 59.

\section{Mississippi}

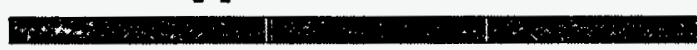

Underground nuclear explosive experiments were conducted at the Salmon Test Site (formerly called Tatum Dome) locared near Hatriesburg. An Agreement-in-Principle with the State of Mississippi regarding remediation was signed in January 1991. Remedial activities were delayed in . 1993, when the landowner refused to lease the property, requesting that the Department purchase the property. The land was sold to the Federal Government at the end of 1994. Remedial activities will resume in 1995.

\section{New Jersey}

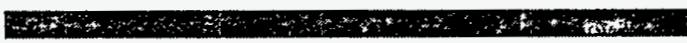

New Jersey has eight sites. These include the Dupont \& Company, Kellex/Peirpont, Maywood, Middlesex Municipal Landfill, Middlesex Sampling Plant, New Brunswick Site, and Wayne sites, which are managed by the FUSRAP program. Discussion of these sites begins on page 59.

The Princeton Plasma Physics Laboratory, leased to the Department of Energy by Princeton University, conducts magnetic confinement plasma physics research and investigates the practical application of fusion power as an energy source. The principal environmental concerns are the ongoing management of hazardous and radioactive waste, underground storage tank remediation, characterization and remediation of ground water, and planning for the disposal of low-level and mixed waste from dismantling the Tokamak Fusion Test Reactor. In 1994, assessment of ground-water contamination continued, and a CERCLA inventory was completed.

In 1994, with a budget of $\$ 6.3$ million, the Laboratory finalized National Environmental Policy Act documentation and the Remedial Investigation Work Plan for its Ground-Water Remediation Project. Preparation of the draft Remedial Investigation report was also initiated, and radioactive and hazardous wastes generated by day-to-day operations at the Laboratory were disposed.

The Laboratory will continue to ship and dispose of hazardous, radioactive, and mixed waste. During 1995, with a budget of $\$ 7.9$ million, the Laboratory will continue routine waste management activities and will complete the Remedial Investigation report. Remedial action and alternative analysis work plans for soil and ground water at two areas onsite will be prepared. Title I and II design will begin for a radioactive waste handling facility.

During 1996 , with a budget of $\$ 5.06$ million, the Laboratory will prepare remedial action and alternative analysis work plans for soil and ground water at two areas onsite. The reactor dismantling 
project will be initiated. Remediation activities for the underground storage tanks project will be completed.

\section{New York}

New York has 12 sites, 9 of which are managed by the FUSRAP program, including the Ashland 1, Ashland 2, Bliss \& Laughlin Steel, Baker \& Williams Warehouses, Colonie, Linde Air Products, Niagara Falls Storage Site, Niagara Falls Storage Site Vicinity Properties, and Seaway Industrial Park sites discussed on pages 59-60.

The West Valley Demonstration Project is carried out at the former Western New York Nuclear Service Center located in Cattaraugus County. The project is working to demonstrate safe immobilization of liquid high-level radioactive waste produced at the site using vitrification. The 1994 budget was $\$ 120.3$ million. During 1994, much of the vitrification facility building and installation of its associated equipment was completed. With part of the site's 1995 budget of $\$ 125.1$ million, the facility will be completed and inspected, and vitrification will begin in 1996. West Valley is currently reducing the volume of liquid high-level waste by treatment in the integrated radioactive waste treatment system. As a result of this treatment, over 18,000 drums of lowlevel waste solidified in cement have been produced and are being safely stored onsite. The sire is also preparing a Draft Environmental Impact Statement for the decontamination and decommissioning of the high-level waste tanks, and the facilities used to solidify the waste. The goal is to issue a Final Environmental Impact Statement in May 1996 and publish a Record of Decision in October 1996. The 1996 budget request for West Valley is $\$ 122.1$ million.

Brookhaven National Laboratory is a multipurpose research and development laboratory that directs scientific and technical efforts including physics, life sciences, and nuclear medicine research. The Laboratory is located on Long Island, about 60 miles east of New York City, and occupies about 8.3 square miles of mostly wooded area. A number of environmental activities are underway to remediate waste generated in connection with the Laboratory's work.

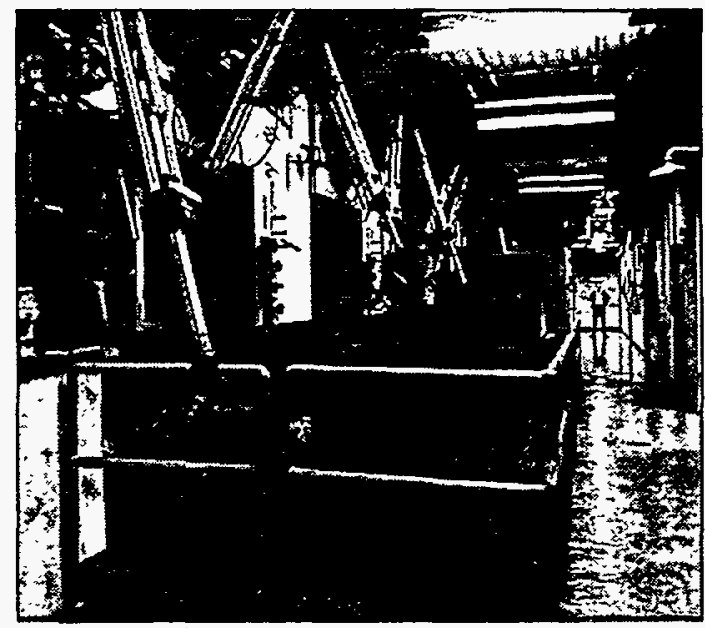

View of West Valley sample cells area.

To prevent continued contamination from leaking underground storage tanks, leaking tanks were removed and other storage tanks were upgraded in 1994. During 1994, with a budget of $\$ 24.1$ million, the Laboratory continued work on its site-wide hydrogeological characterization and the Preliminary Assessment/Sire Investigation. The Laboratory also conducted background investigations for areas of concern, and began field investigations for the Remedial Investigation/ Feasibility Study and the Landfill Engineering Evaluation/Cost Analysis. Remedial Investigation/ Feasibility Study work plans for two other areas onsite were submitted and an interim action and a risk assessment of a third was conducted. A Remedial Investigation/Feasibility Study scope of - work was finalized. Two removal actions were started and one completed. The second phase of design for the waste management facility was completed, and work continued on the floor drain reconnection project.

In 1995 , with a budget of $\$ 26.3$ million, the Laboratory expects to continue work on the sitewide hydrogeological characterization. Once the landfill field investigation is complete, a report will be prepared to evaluate the results of the investigation. This draft report is scheduled to be released in 1995. In addition, contaminated cesspools at Brookhaven have been characterized, and remediation is scheduled to start in 1995. The draft Remedial Investigation/Remedial Action report and preliminary design for the former landfills removal action will be submitted.

Remedial Investigation/Remedial Action, a 


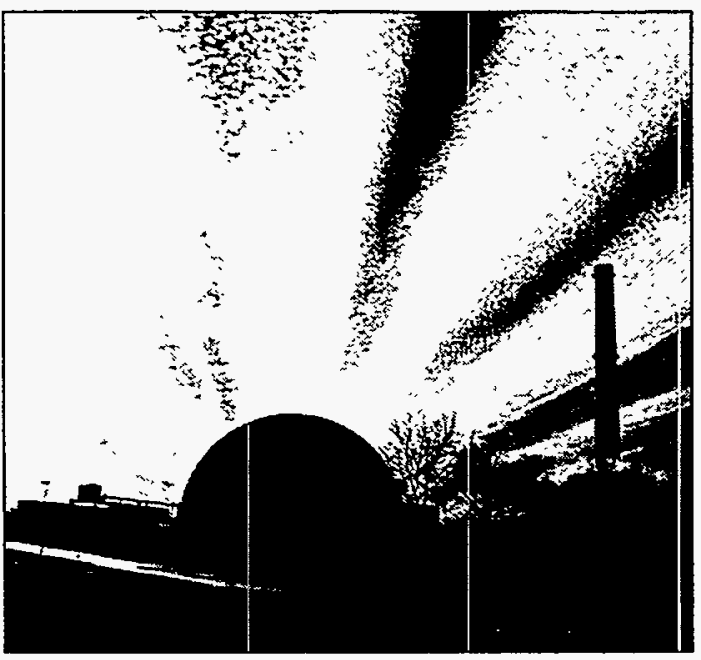

The High Flux Beam Reactor at Brookhaven National Laboratory, which is a powerful tool for investigating the structure and dynamics of condensed matter.

Feasibility Study, and proposed remedial action plan reports will be finalized, and a Record of Decision for Operable Unit 4 will be prepared. Field investigations for the remedial investigation of Operable Units 3 and 5 will begin. Two removal actions will be completed and a third initiated. The floor drain reconnection project will be completed, and construction will continue on the waste management facility.

The Knolls Atomic Power Laboratory contains the Separations Process Research Unit, which was used by the Department of Energy to develop a chemical process for extracting plutonium and uranium from irradiated fuel. Once the process was developed, the operation was transferred to the Hanford Site. The buildings used for the research project will be decontaminated and decommissioned beginning in the year 2000 .

\section{Pennsylvania}

Pennsylvania has five sites. Two of these, Aliquippa Forge and C. H. Schnoor, are part of the FUSRAP program, and the Canonsburg site is managed as part of the UMTRA project.

The Bettis Atomic Power Laboratory is devoted exclusively to the Naval Propulsion Program and includes two sites. Bettis, the primary site, performs research and development on naval nuclear propulsion plants. The Naval Reactors Facility, located within the Idaho National Engineering Laboratory site, operates three prototype naval reactor plants and a facility for examining expended naval reactor cores.

At the Shippingport Atomic Power Station, the first large-scale powerplant in the world, an annual baseline risk assessment began in 1994.

\section{Puerto Rico}

The Center for Energy and Environmental Research was operated by the University of Puerto Rico under contract to the Department and its predecessors. In 1994, an underground storage tank was removed. In addition, asbestos and other chemicals, polychlorinated-biphenyl-contaminated transformers, and soils were removed.

\section{Tennessee}

In addition to the Oak Ridge Reservation, Tennessee has one FUSRAP site, Elza Gate, which is described below.

\section{FUSRAP and UMTRA Sites}

The UMTRA project manages one site in the Eastern region, the Canonsburg former processing site and associated Burrell Vicinity Property sites in Pennsylvania. Remediation was completed in December 1985. Interim surveillance and monitoring continued at Canonsburg while site certification and licensing at Burrell was completed in 1994. Sire responsibility will be transferred to the Grand Junction Projects Office for long-term surveillance and monitoring once the site is certified and licensed in 1995. Following completion of the Baseline Risk Assessment for the ground-water phase of the project, the Department will hold meetings with local citizens and government officials to discuss the initial analysis. Further actions will be taken, if necessary, to 
comply with the ground-water standards established by the Environmental Protection Agency.

The AMAX site, in Parkersburg, West Virginia, was transferred from the private sector licensee to the Department of Energy Grand Junction Projects Office. Site characterization for National Environmental Policy Act compliance was initiated, the first annual site inspection was completed, and work began on the Long-Term Surveillance and Maintenance Plan. Planned accomplishments in 1995 are to complete surveillance, maintenance, and annual reporting activities. Continued site characterization of water sampling at the site; completion of an AMAX site characterization report; and continued annual surveillance, monitoring, and maintenance acrivities will be initiated under a budget of $\$ 866,000$.

- There are 25 sites in the Eastern Region that FUSRAP manages. Environmental management activities have been completed ar the Elza Gate site in Tennessee, the Niagara Falls Storage Site Vicinity Properties and the Baker and Williams Warehouse sites in New York, the Kellex/Peirpont and Middlesex Municipal Landfill sites in New Jersey, and the Seymour Specialty Wire site in Connecticut. At both the Aliquippa Forge site, and C. H. Schnoor site in Pennsylvania, characterization and remedial activities were completed in September 1994.

Remediation acrivities are scheduled to begin after 1996 at the Seaway Industrial Park, Ashland Oil 1, Ashland Oil 2, and Linde Air Products sites in New York pending the conclusion of the remedy selection process.

Limited remedial investigation and characterization has been conducted at the DuPont \& Company site in Deepwater, New Jersey; the W. R. Grace \& Company site in Curtis Bay, Maryland; Chapman Valve site in Indian Orchard, Massachusetts; the Combustion Engineering Site, added in 1994 to the FUSRAP program, in Windsor, Connecticut; and the Bliss and Laughlin Steel site in Buffalo, New York. Characterization has been completed at the Ventron site in Beverly, Massachusetts. The Environmental Management program is working with other Potentially Responsible Parties at the Shpack Landfill site near Norton, Massachusetts, to conduct the remedial investigation/feasibility study of the 5-acre site.

In 1993, the Environmental Management program completed chemical characterization studies at the Middlesex Sampling Plant site near Middlesex, New Jersey, and replaced a cover on a

\section{FUSRAP SITES}

California
University of California*
Connecticut
Seymour Specialty Wire*
Combustion Engineering Site
Illinois
Granite City Steel*
Madison
National Guard Armon"*
University of Chicago*
Maryland
W. R. Grace \& Company
Massachusetts
Chapman Valve
Shpack Landfill
Ventron
Michigan
General Motors
Missouri
Latty Avenue Properties
St. Louis Airport Site
St. Louis Airport Site Vicinity Property
St. Louis Downtown Site

New Jersey
DuPont \& Company
Kellex/Peirpont*
Manwood
Middlesex Municipal Landfil"*
Middlesex Sampling Plant
New Brunswick Laboratory
Wayne
New Mexico
Acid/Pueblo Canyons*
Bayo Canyon*
Chupadera Mesa*
New York
Ashland Oil 1
Ashland Oil 2
Baker and Williams Warehouse*
Bliss \& Laughlin Steel
Colonie
Linde Air Products
Niagara Falls Storage Site*
Niagara Falls Storage Site Vicinity Property*
Seaway Industrial Park

New Jersey

Maywood

Middlesex Municipal Landfill

Middesex Sampling Plant

Acid/Pueblo Canyons*

Bayo Canyon*

Chupadera Mesa

Ashland Oill

Ashland Oil 2

Bliss \& Laughlin Stee

Linde Air Products

Niagara Falls Storage Site

Niagara Falls Storage Sit
Ohio

Alba Craft

Associated Aircraft Toll \& Manufacturing

B \& T Metals

- Baker Brothers

HHM Safe Company

Luckey

Painesville

Oregon

Albany Research Center*

Pennsyivania

Aliquippa Forge*

C.H. Schnoor*

Tennessee

Elza Gate*

*completed remediation and certified in the Federal Register to be released from FUSRAP program 
waste pile to prevent the release of contaminants to the air. Sire characterization studies were completed and a public information center was established in 1993 at the Wayne site in New Jersey. The Environmental Management program also completed draft plans to implement work and remediation, a baseline risk assessment, and remedial investigation. A draft Environmental Impact Statement and Feasibility Study were also submitted to the Environmental Protection Agency. At the Maywood Chemical Works site also in New Jersey, the implementation plan, remedial investigation report, and the baseline risk assessment were completed in 1993. The site also established a public information center and a draft Environmental Impact Statement and Feasibility Study was submitted to the Errvironmental Protection Agency.
The Colonie site in New York completed the draft engineering evaluation and cost analysis, environmental assessment and disposed of solid waste from the site in 1993. During 1994, 1.4 million pounds of metal was removed from the site and recycled. The site also plans to publish the engineering evaluation and cost analysis and the environmental assessment in 1994. Activities scheduled in 1995 include continuing building decontamination and the start of demolition and disposal.

In 1996, the Department plans to conduct the engineering evaluation and cost analysis for the New Brunswick Laboratory in New Jersey.

A study by the National Academy of Science of the Niagara Falls Storage Site in New York is being conducted to analyze the data for the protectiveness of a cap for the site. 


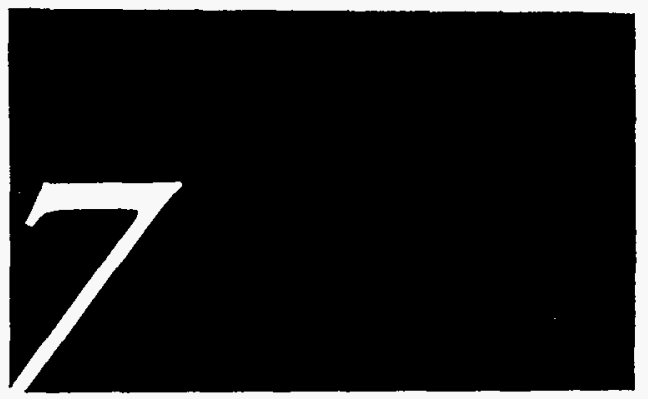

\section{Performance and Funding Data}

\section{Overview}

Since its creation in 1989, Environmental Management's budget and responsibilities have grown dramatically. The budget, $\$ 1.7$ billion in 1989, was approximately $\$ 6$ billion in 1994. In addition to fulfilling the responsibilities outlined in 71 active compliance agreements, we must meet the requirements of the Federal Facilities Compliance Act, manage a growing number of surplus facilities, stabilize and store increasing quantities of nuclear material, and retrain workers and help redevelop communities affected by production plant closings. Such rapid growth without effecrive management and cost controls, and a lack of adequately trained Federal staff, contributed to the major inefficiencies and excessive costs we are beginning to remedy now.

In 1994, Environmental Management initiated several procedures to ensure that all operations within the program were geared to meet the program goals and show a direct relationship between resources expended and results. These initiatives include the formation of Quality Improvement Teams, the allocation of additional Federal employees in the field, contract reform initiatives, and a two-day stand down so that all Environmental Management employees could assess ways to perform their jobs more efficiently.

Some of our problems are common throughour the Federal government, which is why the Clinton Administration has been working hard to "reinvent government." As discussed in the introduction of this report, Environmental Management served as a pilot project under the Government Performance and Results Act in 1994. Under this law, Federal agencies are accountable for achieving program results. The law provides the framework for Federal agencies to link inputs, outputs, and outcomes to assess performance and accomplishments. More detailed information regarding Environmental Management's 1994 Performance Plan, the program's effecriveness in meeting those goals, and how the program will strengthen these efforts in 1995 and 1996 is included in the following section.

This section also provides reports on Environmental Management's progress in meeting its enforceable agreement milestones and operating more efficiently. The National Defense Authorization Act for Fiscal Year 1994 requires that the Environmental Management program report on sites that have a cost variance of 15 percent or $\$ 10$ million or more, and those sites with a schedule variance of 6 months or more in 1995. All data in this section has been provided by the Environmental Management Progress Tracking System or the Office of Financial Management. 
Supporting funding information for the Environmental Management, including detailed site budget information, is presented in this section. As stated earlier in this report, the largest portion of the Environmental Management has historically been for waste management and environmental restoration activities. The Nuclear Material and Facilities Stabilization budget request increased dramatically to manage the growing number of facilities being transferred to Environmental Management from other offices within the Department.

As mentioned previously, budget totals for Hanford include the Hanford Sire and Richland Operations Office. The Idaho National Engineering Laboratory includes the Idaho Chemical Processing Plant and the Idaho Operations Office. The Oak Ridge Reservation budget includes Oak Ridge National Laboratory, the Y-12 Plant, the K-25 Site, Oak Ridge Associated Laboratories, the Oak Ridge Operations Office, and funding for the FUSRAP program.

For more information about the Environmental Management program, or more detailed performance and funding data, please call the Center for Environmental Management Information at 1-800-7-EM-DATA or 1-800-736-3282.

\section{Funding Reports: pages 63-90}

1. Environmental Management 1996 Budget Request for 10 Highest-Funded Sites

2. Environmental Management Budget by Program for 1990-1996

3. Productivity Gains̄ in 1996 for Environmental Management

4. Environmental Management 1996 Budget by State

5. Environmental Management Budget by State, Site, and Program in Descending Order by State Budget Request Totals (1996-1990 Defense and Non-Defense)

\section{Milestone Reports: pages 91-94}

1. Enforceable Agreement Milestones Status

2. Enforceable Agreement Milestones More Than Six Months Overdue

3. Comparison of Environmental Management Performance in Meeting Milestones in 1994 versus 1993

\section{Performance Reports: pages 94-104}

1. Cost and Schedule Performance of Environmental Management Sites in 1994

2. Explanations of Variances

3. Site Cost and Schedule Performance by Program in 1994

4. Comparison of Cost and Schedule Performance in 1994 versus 1993

5. Results of the Performance Measurement Pilot Project 


\section{Funding Reports}

In 1996, Environmental Management will take over management responsibilities for a significant number of facilities formerly managed by the Department of Energy's Defense Program office. These sites include the Savannah River Site in South Carolina, the Mound Plant in Ohio, and the Pinellas Plant in Florida. Although the 1996 request of $\$ 6.6$ billion is $\$ 608$ million greater than the 1995 appropriation, the request includes a $\$ 843$ million intra-departmental transfer of funds for managing surplus former production facilities. The base 1996 budget request of $\$ 5.7$ billion is a 4 percent reduction from the 1995 appropriation of $\$ 5.9$ billion.

The budget reductions for the Department of Energy, and the Environmental Management program, dictate the need to change the way the Department has historically done business. Aggressive steps must be taken to realize necessary productivity improvements and cost reductions. In 1996, savings through efficiency will account for a $\$ 1.3$ billion down payment on meeting even lower budgets for future years. Under Environmental Management's current budgeting structure, the focus is on the national program budgets built around the type of program activity conducted, rather than on the work required at each site where work is being performed. Site managers have little flexibility to reallocate funds provided to the site to achieve efficiencies or to address emerging requirements, because any proposal to shift funds from one budget category to another requires a formal budget reprogramming proposal.

The new Environmental Management strategy requires greater flexibility at the site level to direct resources to the highest priority activities. Site management will be able to negotiate with representatives of State government, regulatory agencies, and stakeholders to prioritize tasks and maximize risk reduction per dollar spent. Thiough a process that structures funding to meet risk- defined priorities and critical compliance milestones, and allows renegotiation of milestones which are not funded, the Department of Energy can meet its compliance obligations and assign resources for competing site activities. This process will be tested on a pilot scale at the Rocky Flats Environmental Technology Site in 1996.

\section{Funding 1. Environmental Management 1996 Budget Request for 10 Highest-Funded Sites}

More than 86 percent of Environmental Management's 1996 Budget Request goes directly to the field to remediate and manage former weapons production sites. Activities at these 10 sites account for more than 80 percent of the program's budget because they include the largest sites with the most complex problems or the most urgent risks or conduct large-scale technology projects.

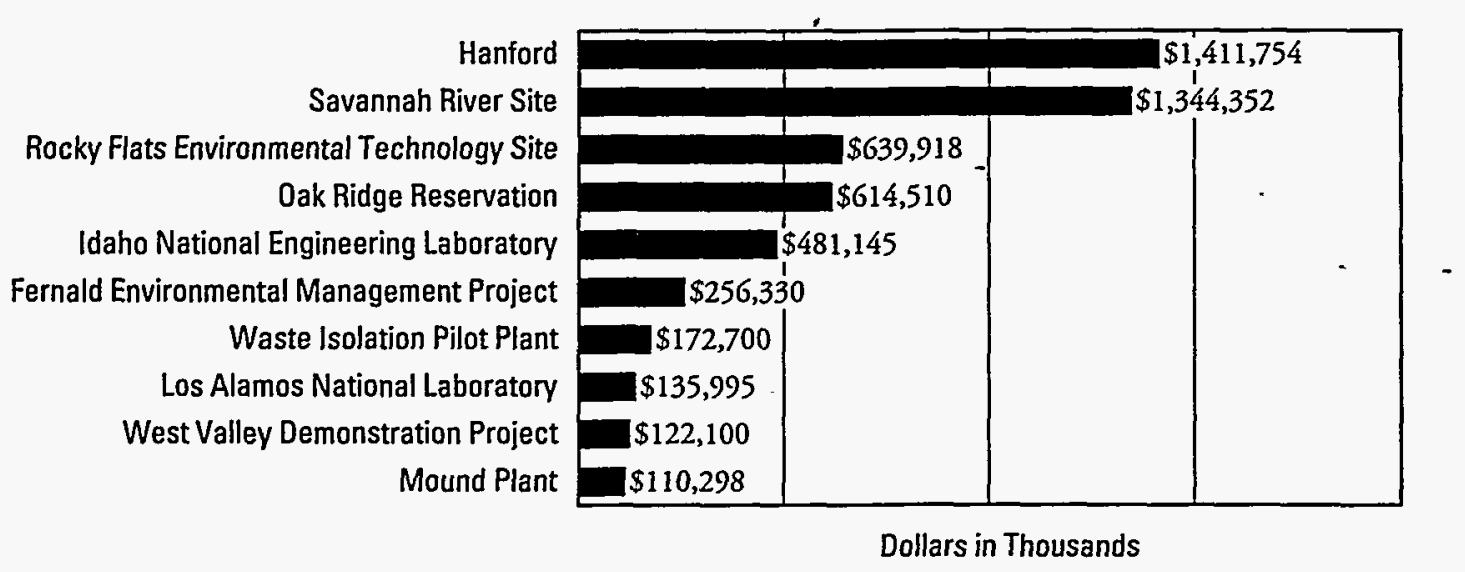

Funding 1. Environmental Management 1996 Budget by Program. 


\section{Funding 2. Environmental Management Budget by Program for 1990-1996}

The Environmental Management program budget increased an average 21 percent annually from 1990 to 1996; however, between 1994 and 1996, the budget increased only 7 percent. This increase is entirely for managing the additional surplus production facilities transferred to Environmental Management from other offices within the Department. The Environmental Management program budget for 1996 reflects the program's efforts to incorporate productivity gains, performance-based budgeting, and productivity savings into all program activities. The program will implement an estimated $\$ 1,046$ million in productivity savings and contractor reductions into its 1996 budget and utilize $\$ 300$ million from prior year's balances.

In 1996, abour 25 percent of the total Environmental Management budget will be used to manage and address the risks at increasing number of surplus production facilities. Approximately 40 percent of the Environmental Management budget is marked for waste management activities. In 1996, more than $\$ 390$ million will be used to accelerate research efforts in waste characterization and -remediation technologies.

The Uranium Enrichment Decontamination and Decommissioning fund was established as a reserve to cover expenses for decontamination and decommissioning, remedial actions, and other activities required by law at uranium enrichment facilities. The Corrective Activities program was established as a limited category of projects designed to correct specific situations in which a facility or installation was out of compliance with applicable environmental laws and regulations. Only those compliance problems requiring immediate resolution were included in this category. Funding for this program is decreasing, and the program is being phased out; however, the activities will continue under the Waste Management program.

\begin{tabular}{|c|c|c|c|c|c|c|c|}
\hline Program & 1990 & 1991 & 1992 & 1993 & 1994 & 1995 & 1996 \\
\hline Waste Management & $\$ 1,303,053$ & $\$ 2,059,220$ & $\$ 2,464,437$ & $\$ 3,339,441$ & $\$ 3,003,006$ & $\$ 2,916,063$ & $\$ 2,707,741$ \\
\hline Corrective Activities & 104,793 & 187,960 & 120,574 & 61,317 & 26,418 & 27,212 & 8,810 \\
\hline Environmental Restoration & 656,829 & $1,102,422$ & $1,379,989$ & $1,852,268$ & $1,819,604$ & $1,768,521$ & $1,993,731$ \\
\hline $\begin{array}{l}\text { Nuclear Material and } \\
\text { Facilities Stabilization }\end{array}$ & N/A & N/A & 0 & 17,861 & 679,541 & 838,853 & $1,679,711$ \\
\hline Technology Development & 183,481 & 235,960 & $303,442{ }^{\prime}$ & 362,200 & 393,797 & 417,359 & 390,510 \\
\hline $\begin{array}{l}\text { Uranium Enrichment D\&D } \\
\text { Fund }\end{array}$ & N/A & N/A & 0 & 0 & 286,320 & 301,327 & 288,807 \\
\hline $\begin{array}{l}\text { Analysis, Education, \& Risk } \\
\text { Management* }\end{array}$ & 13,840 & 32,306 & 24,749 & 50,800 & 91,896 & 84,948 & 157,022 \\
\hline $\begin{array}{l}\text { Compliance and Program } \\
\text { Coordination }\end{array}$ & N/A & N/A & N/A & 0 & 0 & 0 & 81,251 \\
\hline Transportation Management & 12,140 & 15,191 & 18,870 & 19,700 & 19,543 & 20,684 & 16,158 \\
\hline SUBTOTAL & $\$ 2,274,136$ & $\$ 3,633,059$ & $\$ 4,312,061$ & $\$ 5,703,587$ & $\$ 6,320,125$ & $\$ 6,374,967$ & $\$ 7,323,741$ \\
\hline Use of Prior Year Balances & 0 & $(32,380)$ & $(25,162)$ & $(183,260)$ & $(190,308)$ & $(257,481)$ & $(300,000)$ \\
\hline Other Adjustments & 0 & 0 & 0 & 0 & $(129,805)$ & $(133,700)$ & $(432,000)$ \\
\hline TOTAL & $\$ 2,274,136$ & $\$ 3,600,679$ & $\$ 4,286,899$ & $\$ 5,520,327$ & $\$ 6,000,012$ & $\$ 5,983,786$ & $\$ 6,591,741$ \\
\hline
\end{tabular}

Funding 2. Environmental Management Budget by Program 1990-1996 (Dollars in Thousands)

\section{* Formerly combined with Compliance and Program Coordination and entitled Program Direction}




\section{Funding 3. Productivity Gains in 1996 for Environmental Management}

Environmental Management implemented aggressive initiatives to cur the budget requests for 1994 1995, and 1996. By reducing project management costs, contractor personnel, reducing overhead and indirect costs, and supporting service contracts, the Environmental Management program will realize over $\$ 2.0$ billion in permanent budget savings.

The bulk of the proposed productivity savings are based upon commitments made by individual sites to achieve improved program performance through the allocation of additional Federal employees. This increase will be realized through lower indirect costs, increased efficiency through betrer projecr management, and reductions of contractor employees and those related costs.

The size of budget reductions means that Environmental Management "right-size" the contractor workforce across the complex. When the Department ceased defense production activities and began environmental management, additional contractors were hired at facilities across the Nation to perform restoration work, without taking the defense production personnel off the payrolls. The Department will reduce in the contractor workforce primarily through attribution and early out incentives. Environmental Management is commitred to meeting its obligations under Section 3161 of the National Defense Authorization Act for 1993, and offer retraining and hiring preference for affected contractors, in addition to, where appropriate, severance pay for early outs.

Uncosted balances result from time-consuming procurement regulations and delays associated with the need for specialized capital equipment. The vast majority of uncosted balances are marked for work under contract, subcontract, or purchase order or associated with approved work scope.

In 1996, productivity savings of $\$ 1,039$ million will be realized without reductions in planned work scope at the sites, and savings will be achieved by reducing contractor employment. The following table illustrates how these savings will be applied across the program.

\begin{tabular}{l|c|c}
\hline & Productivity Savings & $\begin{array}{c}\text { Use of Prior Year } \\
\text { Balances }\end{array}$ \\
\hline Waste Management & $\$ 500$ & $\$ 300^{*}$ \\
\hline Environmental Restoration & 322 & \\
\hline Nuclear Material and Facilities Stabilization & 214 & \\
\hline Technology Development & 0 & \\
\hline Compliance and Program Coordination & 1 & \\
\hline Analysis, Education, and Risk Management & 7 & \\
\hline Transportation Management & $\cdot$ & \\
\hline \hline Envịronmental Management Program Totals & $\$ 1,046$ & \\
\hline
\end{tabular}

Funding 3. Funding 3. Productivity Gains in 1996 for Environmental Management (dollars in millions)

* Prior Year balances to be allocated by program later in the budget process. 


\section{Funding 4. Environmental Management 1996 Budget by State}

The following States host Department of Energy sites where Environmental Management activities are conducted. More information on the activities at the sites located within these States can be found in the Site Summary section of this report. Please note that the FUSRAP program is managed and funded out of the Oak Ridge (TN) Operations Office and the UMTRA project is managed and funded by the Albuquerque (NM) Operations Office. In the table beginning on the nexr page, you will see each site's total budget, and the budget by program measure within each State. The States are listed in descending order by total budget request.

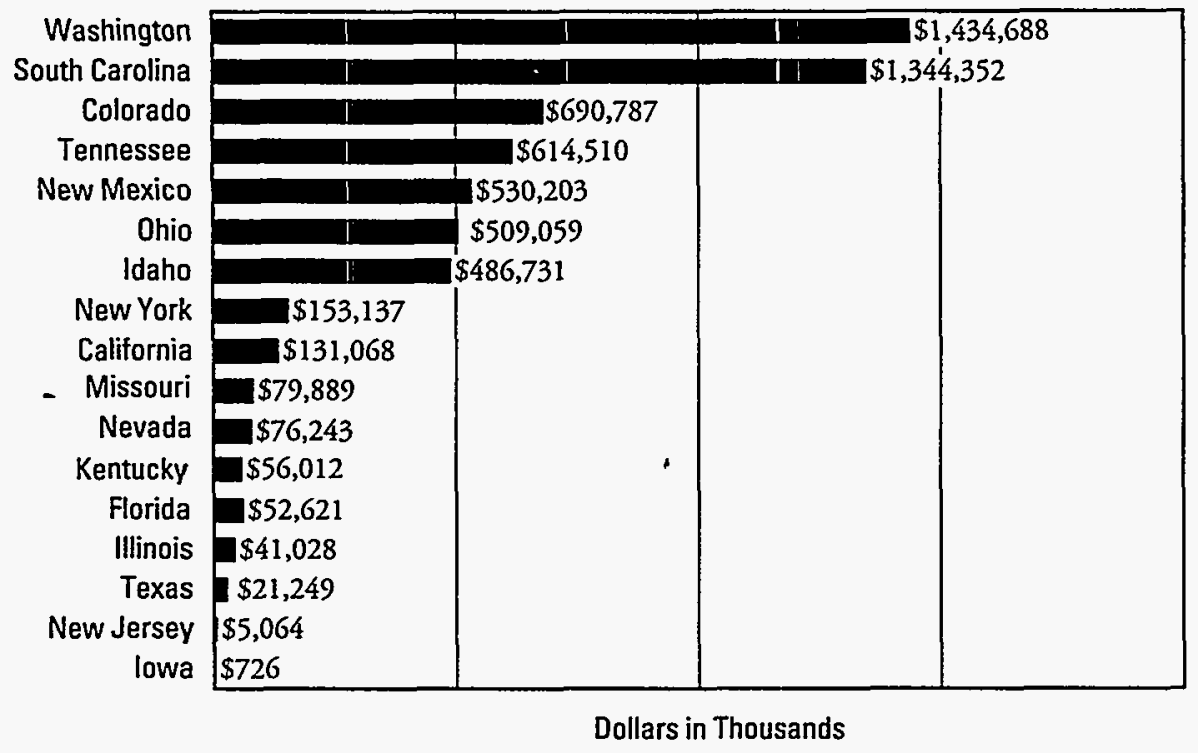

Funding 4. Environmental Management 1996 Budget by State (dollars in thousands), 
Environmental Management Funding by State, Site, and Program in Descending Order by State Budget Request Totals

\begin{tabular}{|c|c|c|c|c|c|c|c|c|c|c|c|c|c|}
\hline \multirow{2}{*}{$\begin{array}{l}\text { STATE } \\
\text { Site (Operations Office) } \\
\text { Program }\end{array}$} & \multicolumn{3}{|c|}{$\begin{array}{c}1996 \\
\text { Congressional Request }\end{array}$} & \multicolumn{3}{|c|}{$\begin{array}{c}1995 \\
\text { Appropriation }\end{array}$} & \multicolumn{3}{|c|}{$\begin{array}{c}1994 \\
\text { Appropriation }\end{array}$} & \multirow{2}{*}{$\begin{array}{l}1993 \\
\text { Total }\end{array}$} & \multirow{2}{*}{$\begin{array}{c}1992 \\
\text { Total }\end{array}$} & \multirow{2}{*}{$\begin{array}{l}1991 \\
\text { Total }\end{array}$} & \multirow{2}{*}{$\begin{array}{l}1990 \\
\text { Total }\end{array}$} \\
\hline & Total & Defense & Non-Def & Total & Defense & Non-Def & Total & Delense & Non-Def & & & & \\
\hline \multicolumn{14}{|l|}{ WASHINGTON } \\
\hline Pacific NW Lab (RL) TOTAL & 22,934 & 22,934 & 0 & 48,969 & 48,969 & 0 & 56,558 & 56,558 & 0 & 64,633 & 45,278 & 23,254 & 17,915 \\
\hline Corrective Activities & 0 & 0 & 0 & 0 & 0 & 0 & 0 & 0 & 0 & 0 & 0 & 0 & 8,176 \\
\hline Waste Management & 22,934 & 22,934 & 0 & 23,035 & 23,035 & 0 & 20,400 & 20,400 & 0 & 0 & 23,693 & 0 & 0 \\
\hline Environmental Restoration & 0 & 0 & 0 & 0 & 0 & 0 & 0 & 0 & 0 & 0 & 0 & 0 & 0 \\
\hline Uranium Enrichment D\&D & 0 & 0 & 0 & 0 & 0 & 0 & 0 & 0 & 0 & 0 & 0 & N/A & N/A \\
\hline Technology Development & 0 & 0 & 0 & 24,789 & 24,789 & 0 & 32,658 & 32,658 & 0 & 64,508 & 21,585 & 23,254 & 9,739 \\
\hline Transportation Management & 0 & 0 & 0 & 145 & 145 & 0 & 0 & 0 & 0 & 125 & 0 & 0 & 0 \\
\hline Nuclear Material \& Fac. Stab. & 0 & 0 & 0 & 1,000 & 1,000 & 0 & 3,500 & 3,500 & 0 & 0 & 0 & N/A & N/A \\
\hline Haniord (RL) TOTAL & 309,724 & 237,860 & 71,864 & 385,641 & 309,903 & 75,738 & 376,852 & 305,822 & 71,030 & 127,276 & 843,141 & 669,456 & 101,023 \\
\hline Corrective Activities & 0 & 0 & 0 & 0 & 0 & 0 & 0 & 0 & 0 & 2,455 & 13,977 & 22,795 & 10.153 \\
\hline Waste Management & 82,201 & 69,837 & 12,364 & 87,872 & 75,894 & 11,978 & 87,743 & 77,369 & 10,374 & 103,062 & 810,553 & 634,711 & 90,870 \\
\hline Environmental Restoration & 0 & 0 & 0 & $\mathbf{0}$ & 0 & 0 & 0 & 0 & 0 & 0 & 0 & N/A & 0 \\
\hline Uranium Enrichment D\&D & 0 & 0 & 0 & 0 & 0 & 0 & 0 & 0 & & 0 & 0 & 0 & N/A \\
\hline Technology Development & 0 & 0 & 0 & 85,579 & 15,579 & D & 24,134 & 24,134 & 0 & 15,820 & 16,424 & 8,838 & 0 \\
\hline Transportation Management & 0 & 0 & 0 & 3,818 & 3,818 & 0 & 0 & 0 & 0 & 4,239 & 2,187 & 3,112 & 0 \\
\hline Nuclear Material \& Fac. Stab. & 227,523 & 168,023 & 59,500 & 278,372 & 214,612 & 63,760 & 264,975 & 204,319 & 60,656 & 1.700 & 0 & N/A & N/A \\
\hline Richland Ops (RL) TOTAL & $1,102,030$ & $1,102,030$ & 0 & $1,141,304$ & $1,141,304$ & 0 & $1,101,237$ & $1,101,237$ & 0 & $1,289,480$ & 171,953 & 135,900 & 352,392 \\
\hline Corrective Activities & 0 & 0 & 0 & 0 & 0 & 0 & o & 0 & 0 & 0 & o & o & $\mathbf{0}$ \\
\hline Waste Management & 841,253 & 841,253 & 0 & 888,932 & 888,932 & 0 & 866,001 & 866,001 & 0 & $1,112,455$ & 9,107 & 0 & 330,993 \\
\hline Environmental Restoration & 173,454 & 173,454 & 0 & 214,442 & 214,442 & 0 & 199,548 & 199,548 & 0 & 175,662 & 161,410 & 135,393 & 0 \\
\hline Uranium Enrichment D\&D & 0 & 0 & 0 & 0 & 0 & 0 & 0 & $\mathbf{0}$ & 0 & 0 & 0 & N/A & N/A \\
\hline Technology Development & 0 & 0 & 0 & 11,261 & 11,261 & 0 & 3,408 & 3,408 & 0 & 1,163 & 1,436 & 507 & 18,943 \\
\hline Transportation Management & 3,728 & 3,728 & 0 & 0 & 0 & 0 & 6,267 & 6,267 & 0 & 0 & 0 & 0 & 2,456 \\
\hline Nuclear Material \& Fac. Stab. & 58,584 & 58,584 & 0 & 26,669 & 26,669 & 0 & 26,013 & 26,013 & 0 & 200 & 0 & N/A & N/A \\
\hline Compliance \& Program Coord. & 25,011 & 25,011 & 0 & 0 & 0 & 0 & 0 & 0 & 0 & 0 & 0 & 0 & N/A \\
\hline
\end{tabular}

Funding 5. Environmental Management Funding by State, Site, and Program in Desecnding Order by State Budget Request Totals. 


\begin{tabular}{|c|c|c|c|c|c|c|c|c|c|c|c|c|c|}
\hline \multirow{2}{*}{$\begin{array}{l}\text { STATE } \\
\text { Sito (Operations Office) } \\
\text { Program }\end{array}$} & \multirow{2}{*}{\multicolumn{3}{|c|}{\begin{tabular}{c|c|c|c}
\multicolumn{3}{c}{1996} \\
\multicolumn{2}{c}{ Congressional Request } \\
Total & Defense & Non-Def
\end{tabular}}} & \multicolumn{3}{|c|}{$\begin{array}{c}1995 \\
\text { Appropriation }\end{array}$} & \multicolumn{3}{|c|}{$\begin{array}{c}1994 \\
\text { Appropriation }\end{array}$} & \multirow{2}{*}{$\begin{array}{l}1993 \\
\text { Total } \\
\end{array}$} & \multirow{2}{*}{$\begin{array}{l}1992 \\
\text { Total } \\
\end{array}$} & \multirow{2}{*}{$\begin{array}{l}991 \\
\text { Total } \\
\end{array}$} & \multirow{2}{*}{$\begin{array}{c}1990 \\
\text { Total }\end{array}$} \\
\hline & & & Non-Def & Total & & Non-Def & Total & Defense & Non-Def & & & & \\
\hline WASHINGTON TOTALS & $1,434,688$ & $1,362,824$ & 71,864 & 1,575,914 & $1,500,176$ & 75,738 & $1,534,647$ & $1,463,617$ & 71,030 & $1,481,389$ & $1,060,372$ & 828,610 & 471,330 \\
\hline Corrective Activities & 0 & 0 & 0 & 0 & 0 & 0 & 0 & 0 & 0 & 2,455 & 13,977 & 22,795 & 18,329 \\
\hline Waste Management & 946,388 & 934,024 & 12,364 & 999,839 & 987,861 & 11,978 & 974,144 & 963,770 & 10,374 & $1,215,517$ & 843,353 & 634,711 & 421,863 \\
\hline Environmental Restoration & 173,454 & 173,454 & 0 & 214,442 & 214,442 & 0 & 199,548 & 199,548 & 0 & 175,662 & 161,410 & 135,393 & 0 \\
\hline Uranium Enrichment D\&D & 0 & 0 & 0 & 0 & 0 & 0 & 0 & 0 & 0 & 0 & 0 & N/A & 0 \\
\hline Technology Development & 0 & 0 & 0 & 51,629 & 51,629 & 0 & 60,200 & 60,200 & 0 & 81,491 & 39,445 & 32,599 & 28,682 \\
\hline Transportation Management & 3,728 & 3,728 & 0 & 3,963 & 3,963 & 0 . & 6,267 & 6,267 & 0 & 4,364 & 2.187 & 3,112 & 2,456 \\
\hline Nuclear Materials \& Fac. Stab. & 286,107 & 226,607 & 59,500 & 306,041 & 242,281 & 63,760 & 294,483 & 233,832 & 60,656 & 1,900 & 0 & N/A & 0 \\
\hline Compliance \& Program Coord. & 25,011 & 25,011 & 0 & 0 & 0 & 0 & 0 & 0 & 0 & N/A & N/A & N/A & 0 \\
\hline \multicolumn{14}{|l|}{ SOUTH CAROLINA } \\
\hline Savannah River (SR) TOTAL & $1,344,352$ & $1,340,052$ & 4,300 & 711,193 & 710,901 & 292 & 763,923 & 763,652 & 27.1 & 779,018 & 550,526 & 644,564 & 471,143 \\
\hline Corrective Activities & & 0 & 10 & 0 & 0 & 0 & 544 & 544 & 0 & 2,143 & 174 & 48,283 & 18,400 \\
\hline Waste Management & 553.757 & 553,757 & 0 & 628,090 & 628,090 & 0 & 646,832 & 646,832 & 0 & 697.454 & 498,715 & 533,964 & 371,997 \\
\hline Environmental Restoration & 104,163 & 99,863 & 4,300 & 64,048 & 63,756 & 292 & 71,926 & 71,655 & 271 & 62,577 & 41,834 & 49,522 & 65,430 \\
\hline Uranium Enrichment D\&D & 0 & 0 & 0 & 0 & 0 & 0 & 0 & 0 & 0 & 0 & 0 & N/A & N/A \\
\hline Technology Development & 0 & 10 & 0 & 18,541 & 18,541 & 0 & 44,621 & 44,621 & 0 & 15,844 & 9,803 & 12,795 & 15,336 \\
\hline Transportation Management & 0 & 0 & 0 & 0 & 0 & 0 & 0 & 0 & 0 & 0 & 0 & 0 & 0 \\
\hline Nuclear Material \& Fac. Stab. & 686,146 & 686,146 & 0 & 514 & 514 & 0 & 0 & 0 & 0 & 1,000 & o & N/A & N/A \\
\hline Compliance \& Program Coord. & 286 & 286 & 0 & 0 & 0 & 0 & 0 & 0 & 0 & N/A & N/A & N/A & 0 \\
\hline \multicolumn{14}{|l|}{ COLORADO } \\
\hline Grand Junction Proj Off (AL) TOTAL & 50,869 & 0 & 50,869 & 38,115 & 1,719 & 36,396 & 30,588 & 2,054 & 28,534 & 31,960 & 23,404 & 30,992 & $N / A$ \\
\hline Corrective Activities & 0 & 0 & 0 & 0 & 0 & 0 & 0 & 0 & 0 & 0 & 0 & 0 & N/A \\
\hline Waste Management & 0 & 0 & 0 & 0 & 0 & 0 & 0 & 0 & 0 & 0 & 0 & 0 & N/A \\
\hline Environmental Restoration & 50,869 & 0 & 50,869 & 36,396 & 0 & 36,396 & 28,838 & 304 & 28,534 & 27.478 & 21,546 & 30,992 & N/A \\
\hline Uranium Enrichment D\&D & 0 & 0 & 0 & 0 & 0 & 0 & 0 & 0 & 0 & 0 & 0 & N/A & N/A \\
\hline Technology Development & 0 & 0 & 0 & 1.719 & 1.719 & 0 & 1.750 & 1,750 & 0 & 4,482 & 1,858 & 0 & N/A \\
\hline Transporration Management & 0 & 0 & 0 & 0 & 0 & 0 & 0 & 0 & 0 & 0 & 0 & 0 & N/A \\
\hline Nuclear Material \& Fac. Stab. & 0 & 0 & 0 & 0 & 0 & 0 & 0 & 0 & 0 & 0 & 0 & N/A & N/A \\
\hline
\end{tabular}

Funding 5. Environmental Management Funding by State, Sitc, and Program in Descending Order by State Budget Requcst Totals. (Continued) 


\begin{tabular}{|c|c|c|c|c|c|c|c|c|c|c|c|c|c|}
\hline \multirow{2}{*}{$\begin{array}{l}\text { STATE } \\
\text { Site (Operations Office) } \\
\text { Program }\end{array}$} & \multicolumn{3}{|c|}{$\begin{array}{c}1996 \\
\text { Congressional Request }\end{array}$} & \multicolumn{3}{|c|}{$\begin{array}{c}1995 \\
\text { Appropriation }\end{array}$} & \multicolumn{3}{|c|}{$\begin{array}{c}1994 \\
\text { Appropriation }\end{array}$} & \multirow{2}{*}{$\begin{array}{l}1993 \\
\text { Total }\end{array}$} & \multirow{2}{*}{1992} & \multirow{2}{*}{$\begin{array}{c}991 \\
\text { Total }\end{array}$} & \multirow{2}{*}{$\begin{array}{l}990 \\
\text { Total } \\
\end{array}$} \\
\hline & Total & Defense & Non-Def & Total & Defense & Non-Def & Total & Defense & Non-Del & & & & \\
\hline Rocky Flats Site (RF) TOTAL & 639,918 & 639,918 & 0 & 618,611 & 618,611 & 0 & 488,716 & 488,716 & 0 & 291,197 & 181,818 & 172,983 & 139,743 \\
\hline Corrective Activities & 0 & 0 & 0 & $\mathbf{0}$ & 0 & 0 & 0 & 0 & 0 & 0 & 9,251 & 1,381 & 1.807 \\
\hline Waste Management & 97,978 & 97,978 & 0 & 115,087 & 115,087 & 0 & 110,716 & 110,716 & 0 & 118,130 & 96,464 & 92,704 & 76,268 \\
\hline Environmental Restoration & 147,753 & 147,753 & 0 & 136,255 & 136,255 & 0 & 144,367 & 144,367 & 0 & 156,462 & 70,000 & 68,350 & 57,997 \\
\hline Uranium Enrichment D\&D & 0 & 0 & 0 & 0 & 0 & 0 & 0 & 0 & 0 & 0 & 0 & N/A & N/A \\
\hline Technology Development & 0 & 0 & 0 & 6,243 & 6,243 & 0 & 8,517 & 8,517 & 0 & 11,644 & 6,053 & 10,548 & 3,671 \\
\hline Transportation Management & 0 & 0 & 0 & 0 & 0 & 0 & 0 & 0 & 0 & 0 & 50 & o & 0 \\
\hline Nuclear Material \& Fac. Stab. & 393,804 & 393,804 & 0 & 361,026 & 361,026 & 0 & 225,116 & 225,116 & 0 & 4,961 & 0 & N/A & N/A \\
\hline Compliance \& Program Coord. & 383 & 383 & 0 & 0 & 0 & 0 & 0 & 0 & 0 & N/A & N/A & N/A & $N / A$ \\
\hline COLORADO TOTALS & 690,787 & 639,918 & 50,869 & 656,726 & 620,330 & 36,396 & 519,304 & 490,770 & 28,534 & 323,157 & 205,222 & 216,188 & 175,891 \\
\hline Corrective Activities & 0 & 0 & 0 & 0 & 0 & 0 & 0 & 0 & 0 & 0 & 9,251 & 1,381 & 1,807 \\
\hline Waste Management & 97,978 & 97,978 & 0 & 115,087 & 115,087 & 0 & 110,716 & 110,716 & 0 & 118,130 & 96,464 & 92,704 & 76,268 \\
\hline Environmental Restoration & 198,622 & 147,753 & 50,869 & 172,651 & 138,255 & 36,396 & 173,205 & 144,671 & 28,534 & 183,940 & 91,546 & 111,555 & 94,075 \\
\hline Uranium Enrichment D\&D & 0 & 0 & 0 & 0 & 0 & 0 & 0 & 0 & 0 & 0 & 0 & N/A & o \\
\hline Technology Development & 0 & 0 & 0 & 7,962 & 7,962 & 0 & 10,267 & 10,267 & 0 & 16,126 & 7,911 & 10,548 & 3,741 \\
\hline Transportation Management & 0 & 0 & 0 & 0 & 0 & 0 & 0 & 0 & 0 & 0 & 50 & 0 & 0 \\
\hline Nuclear Materials \& Fac. Stab. & 393,804 & 393,804 & 0 & 361,026 & $=361,026$ & 0 & 225,116 & 225,116 & 0 & 4,961 & 0 & 0 & 0 \\
\hline Compliance \& Program Coord. & 383 & 383 & 0 & 0 & 0 & 0 & 0 & 0 & 0 & N/A & N/A & N/A & 0 \\
\hline \multicolumn{14}{|l|}{ TENNESSEE } \\
\hline OR Inst. for Science \& Educ & 1,832 & 1,832 & 0 & 1,688 & 1,688 & 0 & 1,464 & 1,464 & 0 & 4,976 & 3,257 & 2,875 & 2,454 \\
\hline Corrective Activities & 0 & 0 & 0 & 0 & 0 & 0 & 0 & 0 & 0 & 0 & 0 & 43 & 0 \\
\hline Waste Management & 0 & 0 & 0 & 0 & 0 & 0 & 0 & 0 & 0 & 0 & 0 & 0 & 12 \\
\hline Environmental Restoration & 1,700 & 1,700 & 0 & 862 & 862 & 0 & 1,464 & 1,464 & o & 2,131 & 0 & 298 & 871 \\
\hline Uranium Enrichment D\&D & 0 & 0 & 0 & 0 & 0 & 0 & 0 & 0 & 0 & 0 & 0 & N/A & N/A \\
\hline Technology Development & 0 & 0 & 0 & 571 & 571 & 0 & 0 & 0 & 0 & 2,845 & 3,257 & 2,534 & 1,571 \\
\hline Transportation Management & 132 & 132 & 0 & 255 & 255 & 0 & 0 & 0 & 0 & 0 & 0 & 0 & o \\
\hline Nuclear Material \& Fac. Stab. & 0 & 0 & 0 & 0 & 0 & 0 & 0 & 0 & 0 & 0 & 0 & N/A & N/A \\
\hline
\end{tabular}

Funding 5. Environmental Management Funding by Statc, Sitc, and Program in Descending Order by Stetc Budget Request Totals. (Comtinucd) 


\begin{tabular}{|c|c|c|c|c|c|c|c|c|c|c|c|c|c|}
\hline \multirow{2}{*}{$\begin{array}{l}\text { STATE } \\
\text { Site (0porations Offico) } \\
\text { Program }\end{array}$} & \multirow{2}{*}{\multicolumn{3}{|c|}{\begin{tabular}{l|l|l}
\multicolumn{3}{c}{1996} \\
\multicolumn{2}{c}{ Congressional Request } \\
Total & Defense & Non-Def
\end{tabular}}} & \multirow{2}{*}{\multicolumn{3}{|c|}{\begin{tabular}{c|}
1995 \\
Appropriation \\
Defense
\end{tabular}}} & \multicolumn{3}{|c|}{$\begin{array}{c}\cdot 1994 \\
\text { Appropriation }\end{array}$} & \multirow{2}{*}{$\begin{array}{l}1993 \\
\text { Total }\end{array}$} & \multirow{2}{*}{$\begin{array}{c}1992 \\
\text { Total }\end{array}$} & \multirow{2}{*}{$\begin{array}{l}1991 \\
\text { Total }\end{array}$} & \multirow{2}{*}{$\begin{array}{l}1990 \\
\text { Total }\end{array}$} \\
\hline & & & & & & & Total & & Non-Def & & & & \\
\hline Y-12 (OR) TOTAL & 63,342 & 63,342 & 0 & 75,523 & 75,523 & 0 & 94,233 & 94,233 & 0 & 108,422 & 88,955 & 76,003 & 76,342 \\
\hline Corrective Activities & 0 & 0 & 0 & 0 & 0 & 0 & 600 & 600 & 0 & 1,030 & 15,777 & 6,000 & 1,478 \\
\hline Waste Management & 47,772 & 47,772 & 0 & 44,781 & 44,789 & 0 & 49,440 & 49,440 & 0 & 55,866 & 58,805 & 42,710 & 47,696 \\
\hline Environmental Restoration & 15,570 & 15,570 & 0 & 30,742 & 30,742 & 0 & 44,193 & 44,193 & 0 & 51,326 & 14,373 & 11,393 & 27,168 \\
\hline Uranium Enrichment D\&D & 0 & 0 & 0 & 0 & 0 & 0 & 0 & 0 & 0 & 0 & 0 & N/A & N/A \\
\hline Technology Development & 0 & 0 & 0 & 0 & 0 & 0 & 0 & 0 & 0 & 0 & 0 & 15,900 & 0 \\
\hline Transportation Management & 0 & 0 & 0 & 0 & 0 & 0 & 0 & 0 & 0 & 0 & 0 & 0 & 0 \\
\hline Nuclear Material \& Fac. Stab. & 0 & 0 & 0 & 0 & 0 & 0 & 0 & 0 & 0 & 200 & 0 & N/A & N/A \\
\hline Oak Ridge Natl Lab (OR) TOTAL & 147,470 & 76,544 & 70,926 & 183,511 & 78,407 & 105,104 & 181,589 & 59,816 & 121,773 & 179,854 & 129,935 & 98,759 & 80,455 \\
\hline Corrective Activities & 5,404 & 0 & 5,404 & 26,700 & 0 & 26,700 & 18,436 & 0 & 18,436 & 16,400 & 11,662 & 8,095 & 12,385 \\
\hline Waste Management & 63,294 & 53,608 & 9,686 & 86,546 & 61.741 & 24,805 & 81,223 & 53,360 & 27,863 & 94,447 & 51,337 & 37,264 & 20,973 \\
\hline Environmental Restoration & 61,822 & 20,116 & 41,706 & 57,039 & 13,016 & 44,023 & 68,918 & 1,985 & 66,933 & 67,507 & 66,936 & 53,400 & 35,438 \\
\hline Uranium Enrichment D\&D & 0 & 0 & 0 & 0 & 0 & 0 & 0 & 0 & 0 & 0 & 0 & N/A & N/A \\
\hline Technology Development & 0 & 0 & 0 & 0 & 0 & 0 & 0 & 0 & 0 & 0 & 0 & 0 & 11,659 \\
\hline Transportation Management & 2,820 & 2,820 & 0 & 3,650 & 3.650 & 0 & 4,471 & 4,471 & 0 & 0 & 0 & 0 & 0 \\
\hline Nuclear Material \& Fac. Stab. & 14,130 & 0 & 14,130 & 9,576 & $0^{\circ}$ & 9,576 & 8,541 & 0 & 8,541 & 1,500 & 0 & N/A & N/A \\
\hline OH Gas Dif Plant (K-25) (OR) TOTAL & 160.461 & 77,827 & 82,634 & 227,336 & 105,121 & 122,215 & 192,955 & 78,171 & 114,784 & 191,590 & 162,709 & 137,283 & 73,775 \\
\hline Corrective Activities & 0 & 0 & 0 & 0 & 0 & 0 & 0 & 0 & 0 & 554 & 1,815 & 1.232 & 325 \\
\hline Waste Management & 60,472 & 60,472 & 0 & 71,057 & 71,057 & 0 & 75,653 & 75,663 & 0 & 94,826 & 63,180 & 18,956 & 21,086 \\
\hline Environmental Restoration & 16,725 & 16,725 & 0 & 34,064 & 34,064 & 0 & 2,508 & 2,508 & 0 & 96,210 & 97,714 & 117,095 & 52,364 \\
\hline Uranium Enrichment D\&D & 82,634 & 0 & 82,634 & 122,215 & 0 & 122,215 & 114,784 & 0 & 114,784 & 0 & 0 & N/A & N/A \\
\hline Technology Development & 0 & 0 & 0 & 0 & 0 & 0 & 0 & 0 & 0 & 0 & 0 & 0 & 0 \\
\hline Transportation Management & 0 & 0 & 0 & 0 & 0 & 0 & 0 & 0 & 0 & 0 & 0 & 0 & 0 \\
\hline Nuclear Material \& Fac. Stab. & 630 & 630 & 0 & 0 & 0 & 0 & 0 & 0 & 0 & 0 & 0 & N/A & N/A \\
\hline
\end{tabular}

Funding 5. Environmental Management Funding by State, Site, and Program in Descending Order by State Budget Request Totals. (Continued) 


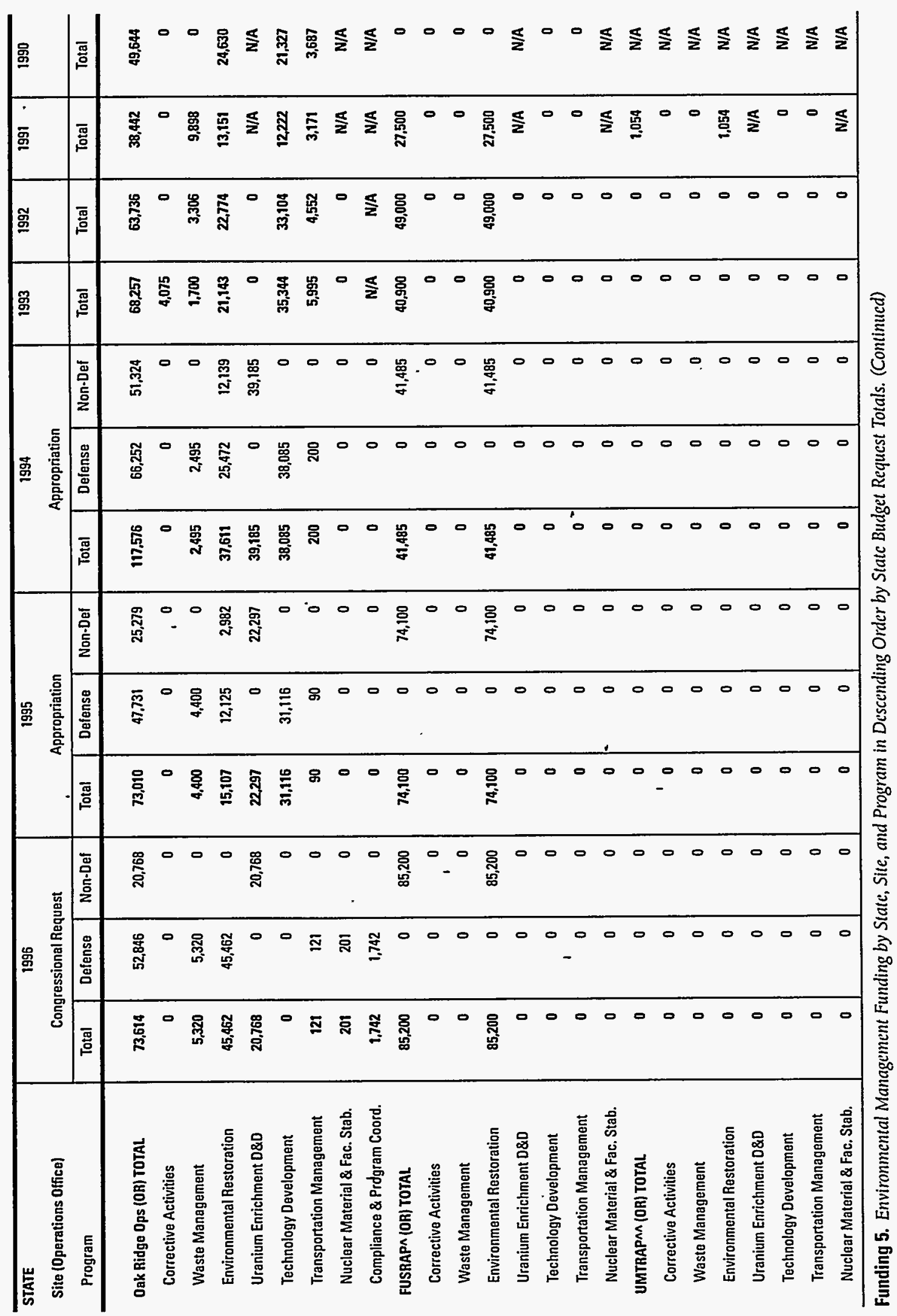




\begin{tabular}{|c|c|c|c|c|c|c|c|c|c|c|c|c|c|}
\hline \multirow{2}{*}{$\begin{array}{l}\text { STATE } \\
\text { Site (Oporations Offico) } \\
\text { Program }\end{array}$} & \multirow{2}{*}{\multicolumn{3}{|c|}{$\begin{array}{c}1996 \\
\text { Congrossional Request }\end{array}$}} & \multicolumn{3}{|c|}{$\begin{array}{c}1995 \\
\text { Appropriation } \\
\end{array}$} & \multicolumn{3}{|c|}{$\begin{array}{c}1994 \\
\text { Appropriation }\end{array}$} & \multirow{2}{*}{$\begin{array}{c}1993 \\
\text { Total }\end{array}$} & \multirow{2}{*}{$\begin{array}{l}1992 \\
\text { Total }\end{array}$} & \multirow{2}{*}{$\begin{array}{l}1991 \\
\text { Total }\end{array}$} & \multirow{2}{*}{$\begin{array}{l}1990 \\
\text { Total } \\
\end{array}$} \\
\hline & & & & Total & Defense & Non-Def & Total & Defonse & Non-Dei & & & & \\
\hline $\begin{array}{l}\text { Center for EN \& ENV Ros. (OR) } \\
\text { TOTAL }\end{array}$ & 0 & 0 & 0 & 0 & 0 & 0 & 0 & 0 & 0 & 0 & 0 & 0 & 0 \\
\hline Corrective Activities & 0 & 0 & 0 & 0 & 0 & 0 & 0 & 0 & 0 & 0 & 0 & 0 & 0 \\
\hline Waste Management & 0 & 0 & 0 & 0 & 0 & 0 & 0 & 0 & 0 & 0 & 0 & 0 & 0 \\
\hline Environmental Restoration & 0 & 0 & 0 & 0 & 0 & 0 & 0 & 0 & 0 & 0 & 0 & 0 & 0 \\
\hline Uranium Enrichment D\&D & 0 & 0 & 0 & 0 & 0 & 0 & 0 & 0 & 0 & 0 & 0 & N/A & o \\
\hline Technology Development & 0 & 0 & 0 & 0 & 0 & 0 & o & 0 & 0 & 0 & 0 & 0 & o \\
\hline Transportation Management & o & 0 & 0 & $\mathbf{0}$ & o & o & 0 & 0 & 0 & 0 & 0 & 0 & 0 \\
\hline Nuclear Material \& Fac. Stab. & 0 & 0 & 0 & 0 & 0 & 0 & 0 & 0 & 0 & 0 & 0 & N/A & 0 \\
\hline Oak Ridge Reservation (OR) TOTAL & 82,591 & 81,270 & 1,321 & 49,550 & 35,835 & 13,715 & 46,386 & 37,075 & 9,311 & 0 & 0 & 0 & 0 \\
\hline Corrective Activities & 0 & 0 & 0 & 0 & 0 & 0 & 0 & 0 & 0 & 0 & 0 & 0 & 0 \\
\hline Waste Management & 66,349 & 66,349 & 0 & 29,619 & 29,619 & 0 & 27,316 & 27,316 & 0 & 0 & 0 & 0 & 0 \\
\hline Environmental Restoration & 14,921 & 14,921 & 0 & 6,216 & 6,216 & 0 & 9.759 & 9,759 & 0 & 0 & 0 & $\mathbf{0}$ & o \\
\hline Uranium Enrichment D\&D & 1,321 & 0 & 1,321 & 13,715 & D & 13,715 & 9,311 & 0 & 9,311 & o & 0 & N/A & 0 \\
\hline Technology Development & 0 & 0 & 0 & 0 & 0 & 0 & 0 & & 0 & 0 & 0 & 0 & 0 \\
\hline Transportation Management & 0 & 0 & 0 & 0 & 0 & 0 & 0 & 0 & 0 & 0 & 0 & 0 & 0 \\
\hline Nuclear Material \& Fac. Stab. & 0 & o & 0 & 0 & 0 & 0 & 0 & 0 & 0 & 0 & 0 & N/A & 0 \\
\hline TENNESSEE TOTALS & 614,510 & 353,661 & 260,849 & 684,718 & 344,305 & 340,413 & 875,688 & 337,011 & 338,677 & 593,999 & 497,592 & 381,916 & 282,670 \\
\hline Corrective Activities & 5,404 & 0 & 5,404 & 26,700 & 0 & 26,700 & 19,025 & 600 & 18,436 & 22,059 & 29,254 & 15,370 & 14,188 \\
\hline Waste Management & 243,207 & 233,521 & 9,686 & 236,403 & 211,598 & 24,805 & 236,137 & 208,274 & 27,863 & 246,839 & 176,628 & 108,828 & 89.767 \\
\hline Environmental Restoration & 241,400 & 114,494 & 126,906 & 218,130 & 97,025 & 121,105 & 205,938 & 85,381 & 120,557 & 279,217 & 250,797 & 223,891 & 140,471 \\
\hline Uranium Enrichment D\&D & 104,723 & 0 & 104,723 & 158,227 & 0 & 158,227 & 163,280 & 0 & 163,280 & 0 & 0 & N/A & 0 \\
\hline Technology Development & 0 & 0 & . 0 & 31,687 & 31,687 & 0 & 38,085 & 38,085 & 0 & 38,189 & 36,361 & 30,656 & 34,557 \\
\hline Transportation Management & 3,073 & 3,073 & 0 & 3,995 & 3,995 & 0 & 4,671 & 4,671 & 0 & $\mathbf{5 , 9 9 5}$ & 4,552 & 3.171 & 3,687 \\
\hline Nuclear Materials \& Fac. Stab. & $\mathbf{1 4 , 9 6 1}$ & 831 & 14,130 & 9,576 & 0 & 9,576 & 8,541 & 0 & 8,541 & 1,700 & 0 & N/A & 1 \\
\hline Compliance \& Program Coord. & 1,742 & 1,742 & 0 & 0 & 0 & 0 & 0 & 0 & 0 & N/A & N/A & N/A & 0 \\
\hline
\end{tabular}

Funding 5. Environmental Management Funding by Statt, Site, and Program in Descending Order by Statc Budget Request Totals. (Continued) 


\begin{tabular}{|c|c|c|c|c|c|c|c|c|c|c|c|c|c|}
\hline \multirow{2}{*}{$\begin{array}{l}\text { STATE } \\
\text { Site (Operations Office) } \\
\text { Program }\end{array}$} & \multicolumn{3}{|c|}{$\begin{array}{c}1996 \\
\text { Congressional Request }\end{array}$} & \multicolumn{3}{|c|}{$\begin{array}{c}1995 \\
\text { Appropriation }\end{array}$} & \multicolumn{3}{|c|}{$\begin{array}{c}1994 \\
\text { Appropriation }\end{array}$} & \multirow{2}{*}{$\begin{array}{l}1993 \\
\text { Total } \\
\end{array}$} & \multirow{2}{*}{$\begin{array}{l}1992 \\
\text { Total } \\
\end{array}$} & \multirow{2}{*}{1991} & \multirow{2}{*}{$\begin{array}{l}1990 \\
\text { Total } \\
\end{array}$} \\
\hline & Total & Defense & Non-Def & Total & Defense & Non-Def & Total & Defensa & Non-Def & & & & \\
\hline \multicolumn{14}{|l|}{ NEW MEXICO } \\
\hline Albuquerque Ops (AL) TOTAL & 90,432 & 48,432 & 42,000 & 91,344 & 49,644 & 41,700 & 97,064 & 56,464 & 40,600 & 34,867 & 21,807 & 41,098 & 83,597 \\
\hline Corrective Activities & 0 & 0 & 0 & 0 & 0 & 0 & 0 & & $\mathbf{0}$ & 0 & 0 & 0 & 0 \\
\hline Waste Management & 18,113 & 18,113 & 0 & 18,373 & 18,373 & 0 & 17,957 & 17,957 & 0 & 13,945 & 10,530 & 5,535 & 325 \\
\hline Environmental Restoration & 25,189 & 25,189 & 0 & 19,872 & 19,872 & 0 & 27,992 & 27.992 & 0 & 9,864 & 8,475 & 10,550 & 65,320 \\
\hline Uranium Enrichment D\&D & 42,000 & 0 & 42,000 & 41,700 & 0 & 41,700 & 40,600 & 0 & 40,600 & 0 & 0 & $N / A$ & N/A \\
\hline Technology Development & 0 & 0 & 0 & $\mathbf{1 0 , 9 6 9}$ & 10,969 & 0 & 10,445 & 10,445 & 0 & 10,858 & 2,802 & 24,310 & 17,952 \\
\hline Transportation Management & 109 & 109 & 0 & 100 & 100 & 0 & 70 & 70 & 0 & 0 & 0 & 703 & 0 \\
\hline Nuclear Material \& Fac. Stab. & 3,264 & 3,264 & 0 & 330 & 330 & 0 & 0 & 0 & 0 & 200 & 0 & $N / A$ & $N / A$ \\
\hline Compliance \& Program Coord. & 1,757 & 1.757 & 0 & o & 0 & 0 & 0 & 0 & 0 & N/A & N/A & $N / A$ & $N / A$ \\
\hline Inhalation Tox (AL) TOTAL & 2,268 & 0 & 2,268 & 2,377 & 0 & 2,377 & 3,216 & 0 & 3,216 & 2,969 & 3,959 & 311 & 1.425 \\
\hline Corrective Activities & o & 0 & 0 & 0 & 0 & 0 & 0 & 0 & 0 & $\mathbf{0}$ & 103 & 80 & 809 \\
\hline Waste Management & 630 & 0 & 630 & 675 & 0 & 675 & 496 & 0 & 496 & 587 & 993 & 166 & 434 \\
\hline Environmental Restoration & 1,638 & 0 & 1,638 & 1,702 & 0 & 1,702 & 2,720 & 0 & 2,720 & 2,382 & 2,863 & 65 & 182 \\
\hline Uranium Enrichment D\&D & 0 & 0 & 0 & 0 & 0 & 0 & 0 & 0 & 0 & 0 & 0 & N/A & N/A \\
\hline Technology Development & 0 & 0 & 0 & 0 & 0 & 0 & 0 & 0 & 0 & 0 & 0 & 0 & 0 \\
\hline Transportation Management & 0 & 0 & 0 & 0 & 0 & 0 & 0 & 0 & 0 & 0 & 0 & 0 & 0 \\
\hline Nuclear Material \& Fac. Stab. & 0 & 0 & 0 & 0 & 0 & 0 & 0 & 0 & 0 & 0 & 0 & N/A & N/A \\
\hline Los Alamos Natl Lab (AL) TOTAL & 135,995 & 135,995 & 0 & 162,226 & 160,615 & 1.611 & 183,712 & 183,224 & 488 & 172,892 & 120,531 & 82,066 & 47,948 \\
\hline Corrective Activities & 3,406 & 3,406 & $\mathbf{0}$ & 0 & 0 & 0 & 2,000 & 2,000 & $\mathbf{0}$ & 10,768 & 13,450 & 12,746 & 7,701 \\
\hline Waste Management & 60,903 & 60,903 & $\mathbf{0}$ & 70,463 & 70,463 & 0 & 81,507 & 81,507 & 0 & 75,426 & 48,037 & 32,160 & 11.068 \\
\hline Environmental Restoration & 64,804 & 64,804 & 0 & 80,516 & 78,905 & 1,611 & 85,480 & 84,992 & 488 & 67,937 & 44,437 & 21,553 & 25,637 \\
\hline Uranium Enrichment D\&D & 0 & $\mathbf{0}$ & 0 & o & 0 & 0 & 0 & 0 & 0 & 0 & 0 & N/A & N/A \\
\hline Technology Development & 0 & $\mathbf{0}$ & 0 & 11,172 & 11,172 & 0 & 14,540 & 14,540 & $\mathbf{0}$ & 17,061 & 14,607 & 15,281 & 3,542 \\
\hline Transportation Management & 58 & 58 & 0 & 75 & 75 & 0 & 185 & 185 & 0 & 50 & 0 & 326 & 0 \\
\hline Nuclear Material \& Fac. Stab. & 6,824 & 6,824 & 0 & 0 & $\mathbf{0}$ & $\mathbf{0}$ & 0 & 0 & 0 & 1,650 & 0 & N/A & N/A \\
\hline
\end{tabular}

Funding 5. Envirommental Management Funding by State, Site, and Program in Descending Order by State' Butget Request Totals. (Comtinued) 


\begin{tabular}{|c|c|c|c|c|c|c|c|c|c|c|c|c|c|}
\hline \multirow{2}{*}{$\begin{array}{l}\text { STATE } \\
\text { Site (Operations Office) } \\
\text { Program }\end{array}$} & \multicolumn{3}{|c|}{$\begin{array}{c}1996 \\
\text { Congressional Request }\end{array}$} & \multicolumn{3}{|c|}{$\begin{array}{c}1995 \\
\text { Appropriation }\end{array}$} & \multicolumn{3}{|c|}{$\begin{array}{c}1994 \\
\text { Appropriation }\end{array}$} & \multirow{2}{*}{$\begin{array}{c}1993 \\
\text { Total }\end{array}$} & \multirow{2}{*}{$\begin{array}{l}1992 \\
\text { Total }\end{array}$} & \multirow{2}{*}{$\begin{array}{l}1991 \\
\text { Total }\end{array}$} & \multirow{2}{*}{$\begin{array}{c}1990 \\
\text { Total }\end{array}$} \\
\hline & Total & Defense & Non-Def & Total & Defense & Non-Def & Total & Defense & Non-Def & & & & \\
\hline Sandia Natl Lab (AL) TOTAL & 41,008 & 41,008 & 0 & 69.225 & 69,225 & 0 & 74,736 & 74,736 & 0 & 73,744 & 58,498 & 37,669 & 16,273 \\
\hline Corrective Activities & 0 & 0 & 0 & 0 & 0 & 0 & 0 & 0 & 0 & 2,651 & 3,308 & 20 & 2,118 \\
\hline Waste Management & 15,118 & 15,118 & 0 & 15,671 & 15,671 & 0 & 16,285 & 16,285 & o & 16,326 & 16,281 & 9,137 & 6,038 \\
\hline Environmental Restoration & 20,180 & 20,180 & 0 & 27,546 & 27,546 & 0 & 25,944 & 25,944 & 0 & 23,013 & 11,774 & 6.020 & 3.721 \\
\hline Uranium Enrichment D\&D & 0 & 0 & 0 & 0 & 0 & 0 & 0 & 0 & 0 & 0 & 0 & N/A & N/A \\
\hline Technology Development & 0 & 0 & 0 & 19,357 & 19,357 & 0 & 25,657 & 25,657 & 0 & 24,782 & 19,435 & 17,351 & 4,396 \\
\hline Transportation Management & 5,710 & 5,710 & 0 & 6,651 & 6,651 & 0 & 6,850 & 6,850 & 0 & 6,972 & 7,700 & 5,141 & 0 \\
\hline Nuclear Material \& Fac. Stab. & 0 & 0 & 0 & 0 & 0 & 0 & 0 & 0 & 0 & 0 & 0 & N/A & N/A \\
\hline UMTRA - S (AL) TOTAL & 80,000 & 0 & 80,000 & 88,117 & 0 & 88,117 & 94,242 & 0 & 94,242 & 134,730 & 139,900 & 86,233 & N/A \\
\hline Corrective Activities & 0 & 0 & 0 & o & 0 & 0 & 0 & 0 & 0 & 0 & 0 & 0 & N/A \\
\hline Waste Management & 0 & 0 & 0 & 0 & 0 & 0 & 0 & 0 & 0 & 0 & 0 & $\mathbf{0}$ & N/A \\
\hline Environmental Restoration & 80,000 & 0 & 80,000 & 88,117 & 0 & 88,117 & 94,242 & 0 & 94,242 & 134.730 & 139,900 & 86,233 & N/A \\
\hline Uranium Enrichment D\&D & 0 & 0 & 0 & 0 & 0 & 0 & 0 & 0 & 0 & 0 & 0 & N/A & N/A \\
\hline Technology Development & 0 & 0 & 0 & 0 & 0 & 0 & 0 & 0 & 0 & 0 & 0 & 0 & N/A \\
\hline Transportation Management & 0 & 0 & 0 & 0 & 0 & $0^{\prime}$ & 0 & 0 & 0 & 0 & 0 & 0 & N/A \\
\hline Nuclear Material \& Fac. Stab. & 0 & 0 & 0 & 0 & 0 & 0 & 0 & 0 & 0 & 0 & 0 & N/A & N/A \\
\hline UMTRA - G (AL) TOTAL & 7,800 & 0 & 7,800 & 7,000 & 0 & 7,000 & 6,794 & 0 & 6,794 & 4,600 & 2,000 & 990 & N/A \\
\hline Corrective Activities & 0 & 0 & 0 & 0 & 0 & 0 & 0 & 0 & 0 & 0 & 0 & 0 & N/A \\
\hline Waste Management & 0 & 0 & 0 & 0 & 0 & 0 & 0 & 0 & 0 & 0 & 0 & 0 & N/A \\
\hline Environmental Restoration & 7,800 & 0 & 7,800 & 7,000 & 0 & 7,000 & 6,794 & 0 & 6,794 & 4,600 & 2,000 & 990 & N/A \\
\hline Uranium Enrichment D\&D & 0 & 0 & 0 & 0 & 0 & 0 & 0 & 0 & 0 & 0 & 0 & N/A & N/A \\
\hline Technology Development & 0 & 0 & 0 & 0 & 0 & 0 & 0 & 0 & 0 & 0 & 0 & 0 & N/A \\
\hline Transportation Management & 0 & 0 & 0 & 0 & 0 & 0 & 0 & 0 & 0 & 0 & 0 & 0 & N/A \\
\hline Nuclear Material \& Fac. Stab. & 0 & 0 & 0 & 0 & 0 & 0 & o & 0 & 0 & 0 & 0 & N/A & N/A \\
\hline WIPP (AL) TOTAL & 172,700 & 172,700 & 0 & 174,323 & 174,323 & 0 & 178,864 & 178,864 & 0 & 150,716 & 140,963 & 164,008 & 104,605 \\
\hline Corrective Activities & 0 & 0 & 0 & 0 & 0 & 0 & 0 & 0 & 0 & 0 & 0 & 0 & 0 \\
\hline Waste Management & 172,700 & 172,700 & 0 & 174,323 & 174,323 & 0 & 178,864 & 178,864 & 0 & 150,716 & 140,963 & 164,008 & 104,605 \\
\hline Environmental Restoration & 0 & 0 & 0 & 0 & 0 & 0 & 0 & 0 & 0 & 0 & 0 & 0 & 0 \\
\hline Uranium Enrichment D\&D & 0 & 0 & 0 & 0 & 0 & 0 & 0 & 0 & 0 & 0 & 0 & N/A & N/A \\
\hline Technology Delvelopment & 0 & 0 & 0 & 0 & 0 & 0 & 0 & 0 & 0 & 0 & 0 & 0 & 0 \\
\hline Transportation Management & 0 & $\mathbf{0}$ & 0 & 0 & 0 & 0 & 0 & 0 & $\mathbf{0}$ & 0 & 0 & 0 & 0 \\
\hline Nuclear Material \& Fac. Stab. & 0 & 0 & 0 & 0 & 0 & 0 & 0 & 0 & 0 & 0 & 0 & N/A & N/A \\
\hline
\end{tabular}

Funding 5. Environmental Management Funding by State, Site, and Program in Descending Order by State Budget Request Totals. (Continued) 


\begin{tabular}{|c|c|c|c|c|c|c|c|c|c|c|c|c|c|}
\hline \multirow{2}{*}{$\begin{array}{l}\text { STATE } \\
\text { Site (Operations Office) } \\
\text { Program }\end{array}$} & \multicolumn{3}{|c|}{$\begin{array}{c}1996 \\
\text { Congressional Request } \\
\end{array}$} & \multicolumn{3}{|c|}{$\begin{array}{c}1995 \\
\text { Appropriation }\end{array}$} & \multicolumn{3}{|c|}{$\begin{array}{c}1994 \\
\text { Appropriation }\end{array}$} & \multirow{2}{*}{$\begin{array}{l}1993 \\
\text { Total } \\
\end{array}$} & \multirow{2}{*}{$\begin{array}{l}1992 \\
\text { Total } \\
\end{array}$} & \multirow{2}{*}{$\begin{array}{l}1991 \\
\text { Total } \\
\end{array}$} & \multirow{2}{*}{$\begin{array}{l}1990 \\
\text { Total } \\
\end{array}$} \\
\hline & Total & Defense & Non-Def & Total & Delense & Non-Def & Total & Defense & Non-Def & & & & \\
\hline NEW MEXICO TOTALS & 530,203 & 398,135 & 132,068 & 594,612 & 453,807 & 140,805 & 638,628 & 493,288 & 145,340 & 574,518 & 487,658 & 412,375 & 253,848 \\
\hline Corrective Activities & 3,406 & 3,406 & 0 & 0 & 0 & 0 & 2,000 & 2,000 & 0 & 13,419 & 16,861 & 12,846 & 10,628 \\
\hline Waste Management & 267,464 & 266,834 & 630 & 279,505 & 278.830 & 675 & 295,109 & 294,613 & 496 & 257,000 & 216,804 & 211,006 & 122,470 \\
\hline Environmental Restoration & 199,611 & 110,173 & 89,438 & 224,753 & 126,323 & 98,430 & 243,172 & 138,928 & 104,244 & 242,526 & 209,449 & 125,411 & $\mathbf{9 4 , 8 6 0}$ \\
\hline Urenium Enrichment D\&D & 42,000 & 0 & 42,000 & 41,700 & 0 & 41,700 & 40,600 & 0 & 40,600 & 0 & 0 & $\mathbf{N} / \mathbf{A}$ & 0 \\
\hline Technology Development & 0 & 0 & 0 & 41,498 & 41,498 & 0 & 50,642 & 50,642 & 0 & 52,701 & 36,844 & 56,942 & 25,890 \\
\hline Transportation Management & 5,877 & 5,877 & 0 & 6,826 & 6,826 & 0 & 7,105 & 7,105 & 0 & 7,022 & 7,700 & 6.170 & 0 \\
\hline Nuclear Materials \& Fac. Stab. & 10,088 & 10,088 & 0 & 330 & 330 & 0 & 0 & 0 & 0 & 1,850 & 0 & N/A & o \\
\hline Compliance \& Program Coord. & 1,757 & 1,757 & 0 & 0 & 0 & 0 & 0 & 0 & 0 & N/A & N/A & N/A & 0 \\
\hline \multicolumn{14}{|l|}{$\overline{\mathrm{OH}}$} \\
\hline Fernald (OH) TOTAL & 256,330 & 256,330 & 0 & 261,677 & 261,677 & 0 & 300,747 & 300,747 & 0 & 293,892 & 214.293 & 263,628 & 84,424 \\
\hline Corrective Activities & 0 & 0 & 0 & 0 & 0 & 0 & 0 & 0 & 0 & 0 & 0 & 48,464 & 10,186 \\
\hline Waste Management & $\mathbf{0}$ & 0 & 0 & 0 & 0 & 0 & 0 & 0 & 0 & 0 & o & 33,682 & 32,285 \\
\hline Environmental Restoration & 256,330 & 256,330 & 0 & 257,711 & 257.711 & 0 & 299,128 & 299,128 & 0 & 291,820 & 211,402 & 179,186 & 41,953 \\
\hline Uranium Enrichment D\&D & 0 & 0 & 0 & 0 & 0 & 0 & 0 & 0 & 0 & 0 & 0 & N/A & N/A \\
\hline Technology Development & 0 & 0 & 0 & 3,966 & 3,966 & 0 & 1.619 & 1,619 & 0 & 2,072 & 2,891 & 2,296 & N/A \\
\hline Transportation Management & 0 & 0 & 0 & 0 & 0 & 0 & 0 & 0 & 0 & $\mathbf{0}$ & 0 & 0 & N/A \\
\hline Nuclear Material \& Fac. Stab. & 0 & 0 & 0 & 0 & 0 & 0 & 0 & 0 & 0 & 0 & 0 & N/A & N/A \\
\hline Mound Site (OH) TOTAL & 110,298 & 109,075 & 1,223 & 43,061 & 41,325 & 1,736 & 41,637 & 41,634 & 3 & 44,457 & 42,217 & 30,682 & 19,058 \\
\hline Corrective Activities & 0 & 0 & 0 & 0 & 0 & 0 & 0 & 0 & 0 & 0 & 41 & 1,755 & 2,700 \\
\hline Wasto Management & 10,386 & 10,386 & 0 & 11,530 & 11,530 & 0 & 12,018 & 12,018 & 0 & 9,130 & 7,300 & 4,680 & 4,897 \\
\hline Environmental Restoration & 46,091 & 44,868 & 1,223 & 31,182 & 29,446 & 1,736 & 29,619 & 29,616 & 3 & 34,127 & 34,876 & 24,247 & 11,451 \\
\hline Uranium Enrichment D\&D & 0 & 0 & 0 & 0 & 0 & 0 & 0 & 0 & 0 & 0 & 0 & N/A & N/A \\
\hline Technology Development & 0 & 0 & 0 & 0 & 0 & 0 & 0 & o & 0 & 0 & 0 & 0 & 10 \\
\hline Transportation Management & 0 & 0 & 0 & 0 & 0 & 0 & 0 & 0 & 0 & 0 & 0 & 0 & 0 \\
\hline Nuclear Material \& Fac. Stab. & 53,821 & 53,821 & 0 & 349 & 349 & 0 & 0 & 0 & 0 & 1,200 & 0 & N/A & N/A \\
\hline
\end{tabular}

Funding 5. Envirommental Management Funding by State, Site, and Program in Descending Order by State Butget Request Totals. (Continued) 


\begin{tabular}{|c|c|c|c|c|c|c|c|c|c|c|c|c|c|}
\hline \multirow{2}{*}{$\begin{array}{l}\text { STATE } \\
\text { Site (Operations Office) } \\
\text { Program }\end{array}$} & \multicolumn{3}{|c|}{$\begin{array}{c}1996 \\
\text { Congressional Request }\end{array}$} & \multicolumn{3}{|c|}{1995} & \multicolumn{3}{|c|}{$\begin{array}{c}1994 \\
\text { Appropriation }\end{array}$} & \multirow{2}{*}{$\begin{array}{l}1993 \\
\text { Total } \\
\end{array}$} & \multirow{2}{*}{$\begin{array}{l}1992 \\
\text { Total } \\
\end{array}$} & \multirow{2}{*}{$\begin{array}{l}1991 \\
\text { Total } \\
\end{array}$} & \multirow{2}{*}{$\begin{array}{l}1990 \\
\text { Total } \\
\end{array}$} \\
\hline & Total & Defense & Non-Def & Total & Defense & Non-Def & Total & Defense & Non-Def & & & & \\
\hline Battello Columbus (CH) TOTAL & 20,700 & 4,694 & 16,006 & 19,150 & 1,800 & 17,350 & 17,594 & 2,364 & 15,230 & 24,580 & 20,947 & 12,621 & 1,777 \\
\hline Corrective Activities & 0 & 0 & 0 & 0 & 0 & 0 & 0 & 0 & 0 & 0 & 0 & 0 & 0 \\
\hline Waste Management & 0 & 0 & 0 & 0 & 0 & 0 & 0 & 0 & 0 & 0 & 0 & 0 & 0 \\
\hline Environmental Restoration & 20,700 & 4,694 & 16,006 & 19,150 & 1.800 & 17,350 & 17,594 & 2,364 & 15,230 & 24,580 & 20,947 & 12,621 & 1,777 \\
\hline Uranium Enrichment D\&D & o & o & 0 & 0 & 0 & 0 & 0 & 0 & 0 & 0 & 0 & N/A & N/A \\
\hline Technology Development & 0 & 0 & 0 & 0 & 0 & 0 & 0 & 0 & 0 & 0 & 0 & 0 & 0 \\
\hline Transportation Management & 0 & 0 & 0 & 0 & 0 & 0 & 0 & 0 & 0 & 0 & 0 & 0 & 0 \\
\hline Nuclear Material \& Fac. Stab. & 0 & 0 & 0 & 0 & 0 & 0 & 0 & 0 & 0 & 0 & 0 & N/A & N/A \\
\hline Portsmouth GDP (OR) TOTAL & 86,072 & 0 & 86,072 & 59,847 & 10,747 & 49,100 & 70,412 & 15,349 & 55,063 & 26,316 & 28,852 & 0 & 0 \\
\hline Corrective Activities & $\mathbf{0}$ & 0 & 0 & 0 & 0 & 0 & 0 & 0 & 0 & 0 & 0 & 0 & 0 \\
\hline Waste Management & 0 & 0 & 0 & 0 & 0 & 0 & 0 & 0 & 0 & 0 & 0 & 0 & 0 \\
\hline Environmental Restoration & 0 & 0 & 0 & 10,747 & 10,747 & 0 & 15,349 & 15,349 & 0 & 26,316 & 28,852 & 0 & 0 \\
\hline Uranium Enrichment D\&D & 86,072 & 0 & 86,072 & 49,100 & 0 & 49,100 & 55,063 & 0 & 55,063 & 0 & 0 & N/A & N/A \\
\hline Technology Development & 0 & 0 & 0 & 0 & 0 & 0 & 0 & 0 & 0 & 0 & 0 & 0 & 0 \\
\hline Transportation Management & 0 & 0 & 0 & 0 & 0 & 0 & 0 & 0 & 0 & 0 & 0 & 0 & 0 \\
\hline Nuclear Material \& Fac. Stab. & 0 & 0 & 0 & 0 & 0 & 0 & 0 & 0 & 0 & 0 & 0 & N/A & N/A \\
\hline Reactive Metals Inc (CH) TOTAL & 11,124 & 11,124 & 0 & 6,590 & - 6,590 & 0 & 12,506 & 12,506 & 0 & 11,297 & N/A & o & N/A \\
\hline Corrective Activities & $\mathbf{0}$ & 0 & 0 & 0 & 0 & 0 & 0 & 0 & 0 & 0 & N/A & 0 & N/A \\
\hline Waste Management & 0 & 0 & 0 & 0 & 0 & 0 & 0 & 0 & 0 & 0 & N/A & 0 & N/A \\
\hline Environmental Restoration & 11,124 & 11,124 & 0 & 6,590 & 6,590 & 0 & 12,506 & 12,506 & 0 & 11,297 & N/A & 0 & N/A \\
\hline Uranium Enrichment D\&D & 0 & 0 & 0 & 0 & 0 & 0 & 0 & 0 & 0 & 0 & N/A & N/A & N/A \\
\hline Technology Development & 0 & 0 & 0 & 0 & 0 & 0 & 0 & 0 & 0 & 0 & N/A & o & $N / A$ \\
\hline Transportation Management & 0 & 0 & 0 & 0 & 0 & 0 & 0 & 0 & 0 & 0 & N/A & 0 & N/A \\
\hline Nuclear Material \& Fac. Stab. & 0 & 0 & 0 & 0 & 0 & 0 & 0 & 0 & 0 & 0 & N/A & N/A & N/A \\
\hline Ohio Field Office $(\mathrm{OH})$ TOTAL & 24,535 & 24,535 & 0 & 7,916 & 7,916 & 0 & 10,931 & 10,931 & 0 & 0 & N/A & N/A & N/A \\
\hline Corrective Activities & o & 0 & 0 & 0 & 0 & 0 & 0 & 0 & 0 & 0 & N/A & N/A & N/A \\
\hline Waste Management & 5,684 & 5,684 & 0 & 0 & 0 & 0 & 0 & 0 & 0 & 0 & N/A & N/A & N/A \\
\hline Environmental Restoration & 14,867 & 14,867 & 0 & 7,818 & 7,818 & 0 & 10,931 & 10,931 & 0 & 0 & N/A & N/A & N/A \\
\hline Uranium Enrichment D\&D & o & 0 & 0 & 0 & 0 & 0 & 0 & 0 & 0 & 0 & N/A & N/A & N/A \\
\hline Technology Development & 0 & 0 & 0 & 98 & 98 & 0 & 0 & 0 & 0 & 0 & N/A & $\mathbf{N} / \mathbf{A}$ & N/A \\
\hline Transportation Management & 0 & 0 & 0 & 0 & 0 & 0 & 0 & 0 & 0 & 0 & N/A & N/A & N/A \\
\hline Nuclear Material \& fac. Stab. & 3.698 & 3,698 & 0 & 0 & 0 & 0 & 0 & 0 & 0 & 0 & N/A & N/A & N/A \\
\hline Compliance \& Program Coord. & 286 & 286 & 0 & 0 & 0 & 0 & 0 & 0 & 0 & 0 & N/A & N/A & N/A \\
\hline
\end{tabular}

Funding 5. Environmental Management Funding by State, Site, and Program in Descending Order by State Budget Request Totals. (Continued) 


\begin{tabular}{|c|c|c|c|c|c|c|c|c|c|c|c|c|c|}
\hline \multirow{2}{*}{$\begin{array}{l}\text { STATE } \\
\text { Site (Operations Office) } \\
\text { Program }\end{array}$} & \multicolumn{3}{|c|}{$\begin{array}{c}1996 \\
\text { Congressional Request } \\
\end{array}$} & \multicolumn{3}{|c|}{$\begin{array}{c}1995 \\
\text { Appropriation }\end{array}$} & \multicolumn{3}{|c|}{$\begin{array}{c}1994 \\
\text { Appropriation }\end{array}$} & \multirow{2}{*}{$\begin{array}{l}1993 \\
\text { Total } \\
\end{array}$} & \multirow{2}{*}{$\begin{array}{l}1992 \\
\text { Total } \\
\end{array}$} & \multirow{2}{*}{$\begin{array}{l}1991 \\
\text { Total } \\
\end{array}$} & \multirow{2}{*}{$\begin{array}{l}1990 \\
\text { Total } \\
\end{array}$} \\
\hline & Total & Delense & Non-Def & Total & Defense & Non-Def & Total & Defense & Non-Def & & & & \\
\hline OHIO TOTALS & 509,059 & 405,758 & 103,301 & 398,241 & 330,055 & 68,186 & 453,827 & 383,531 & 70,296 & 400,542 & 306,309 & 306,931 & 105,259 \\
\hline Corrective Activities & 0 & 0 & 0 & 0 & 0 & 0 & 0 & 0 & 0 & 0 & 41 & 50,219 & 12886 \\
\hline Waste Management & 16,070 & 16,070 & 0 & 11,530 & 11,530 & 0 & 12,018 & 12,018 & 0 & 9.130 & 7,300 & 38,362 & 37,182 \\
\hline Environmental Restoration & 349,112 & 331,883 & 17,229 & 333,198 & 314,112 & 19,086 & 385,127 & $369^{\prime}, 894$ & 15,233 & 388,140 & 296,077 & 216,054 & 55,181 \\
\hline Uranium Enrichment D\&D & 86,072 & 0 & 86,072 & 49,100 & 0 & 49,100 & 55,063 & 0 & 55,063 & 0 & 0 & N/A & N/A \\
\hline Technology Development & $\mathbf{0}$ & 0 & 0 & 4.064 & 4,084 & 0 & 1,619 & 1,619 & 0 & 2,072 & 2.891 & 2,296 & 10 \\
\hline Transportation Management & 0 & 0 & 0 & 0 & 0 & 0 & 0 & 0 & 0 & 0 & 0 & 0 & 0 \\
\hline Nuclear Materials \& Fac. Stab. & 57,519 & 57,519 & 0 & 349 & 349 & 0 & 0 & 0 & 0 & 1,200 & 0 & N/A & N/A \\
\hline Compliance \& Program Coord. & 286 & 286 & 0 & 0 & 0 & 0 & 0 & 0 & 0 & N/A & N/A & N/A & N/A \\
\hline \multicolumn{14}{|l|}{ IDAHO } \\
\hline Idaho Chem Process (ID) TOTAL & 207.477 & 207,477 & 0 & 204,874 & 204,874 & 0 & 210,753 & 210,753 & 0 & 165,909 & 99,225 & 101,636 & 39,786 \\
\hline Corrective Activities & 0 & 0 & 0 & 0 & 0 & 0 & 0 & 0 & 0 & 0 & 7,000 & 4,550 & 3,751 \\
\hline Waste Management & 111,708 & 111,708 & 0 & 116,423 & 116,423 & 0 & 127,505 & 127,505 & 0 & 160,193 & 89,647 & 92,623 & 36,035 \\
\hline Environmental Restoration & 0 & 0 & 0 & 0 & 0 & 0. & 0 & 0 & 0 & 0 & 0 & o & 0 \\
\hline Uranium Enrichment D\&D & 0 & 0 & 0 & 0 & 0 & $0^{\circ}$ & 0 & 0 & 0 & $\mathbf{0}$ & 0 & N/A & N/A \\
\hline Technology Development & 0 & 0 & 0 & 0 & 0 & 0 & 0 & 0 & 0 & 5,416 & 2,578 & 4,463 & 0 \\
\hline Transportation Management & 0 & 0 & 0 & 0 & 0 & 0 & 0 & 0 & 0 & 0 & o & 0 & 0 \\
\hline Nuclear Material \& Fac. Stab. & 95,769 & 95,769 & 0 & 88,451 & 88,451 & 0 & 83,248 & 83,248 & 0 & 300 & 0 & N/A & $N / A$ \\
\hline Idaho Natl Eng. Lab (ID) TOTAL & 244,427 & 231,109 & 13,318 & 268,338 & 262,862 & 5,476 & 258,125 & 250,421 & 7,704 & 207,044 & 149,220 & 221,617 & 145,764 \\
\hline Corrective Activities & 0 & 0 & 0 & 0 & 0 & 0 & 0 & 0 & 0 & 0 & 0 & 9,428 & 4,210 \\
\hline Waste Management & 94,603 & 89,420 & 5,183 & 102,867 & 97,391 & 5,476 & 125,390 & 117,686 & 7.704 & 188,916 & 132,593 & 132,171 & 61,040 \\
\hline Environmental Restoration & 87,914 & 87,914 & 0 & 116,253 & 116,253 & 0 & 87,956 & 87,956 & 0 & 0 & o & 50,408 & 45,638 \\
\hline Uranium Enrichment D\&D & 0 & 0 & 0 & 0 & 0 & 0 & 0 & 0 & 0 & 0 & 0 & N/A & N/A \\
\hline Technology Development & 0 & 0 & 0 & 864 & 864 & 0 & 1,111 & 1,111 & 0 & 17,983 & 16,627 & 29,496 & 34,876 \\
\hline Transportation Management & 0 & 0 & 0 & 0 & 0 & 0 & 0 & 0 & 0 & 0 & o & 114 & 0 \\
\hline Nuctear Material \& Fac. Stab. & 61,910 & 53,775 & 8,135 . & 48,354 & 48,354 & 0 & 43,668 & 43,668 & 0 & 145 & 0 & N/A & N/A \\
\hline
\end{tabular}

Funding 5. Environmental Management Funding by Statc, Site, and Program in Descending Order by State Budget Request Totals. (Contimued) 


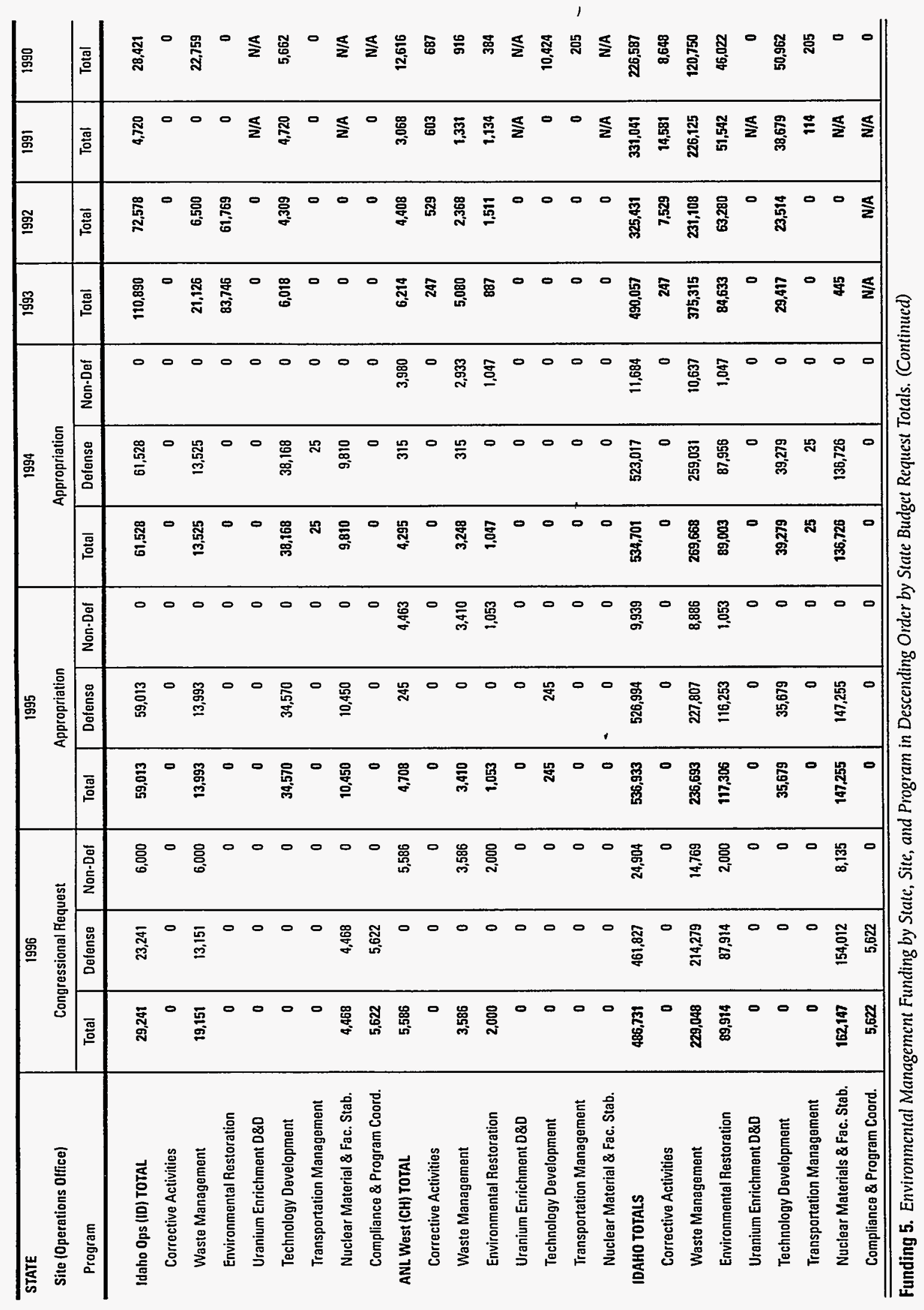




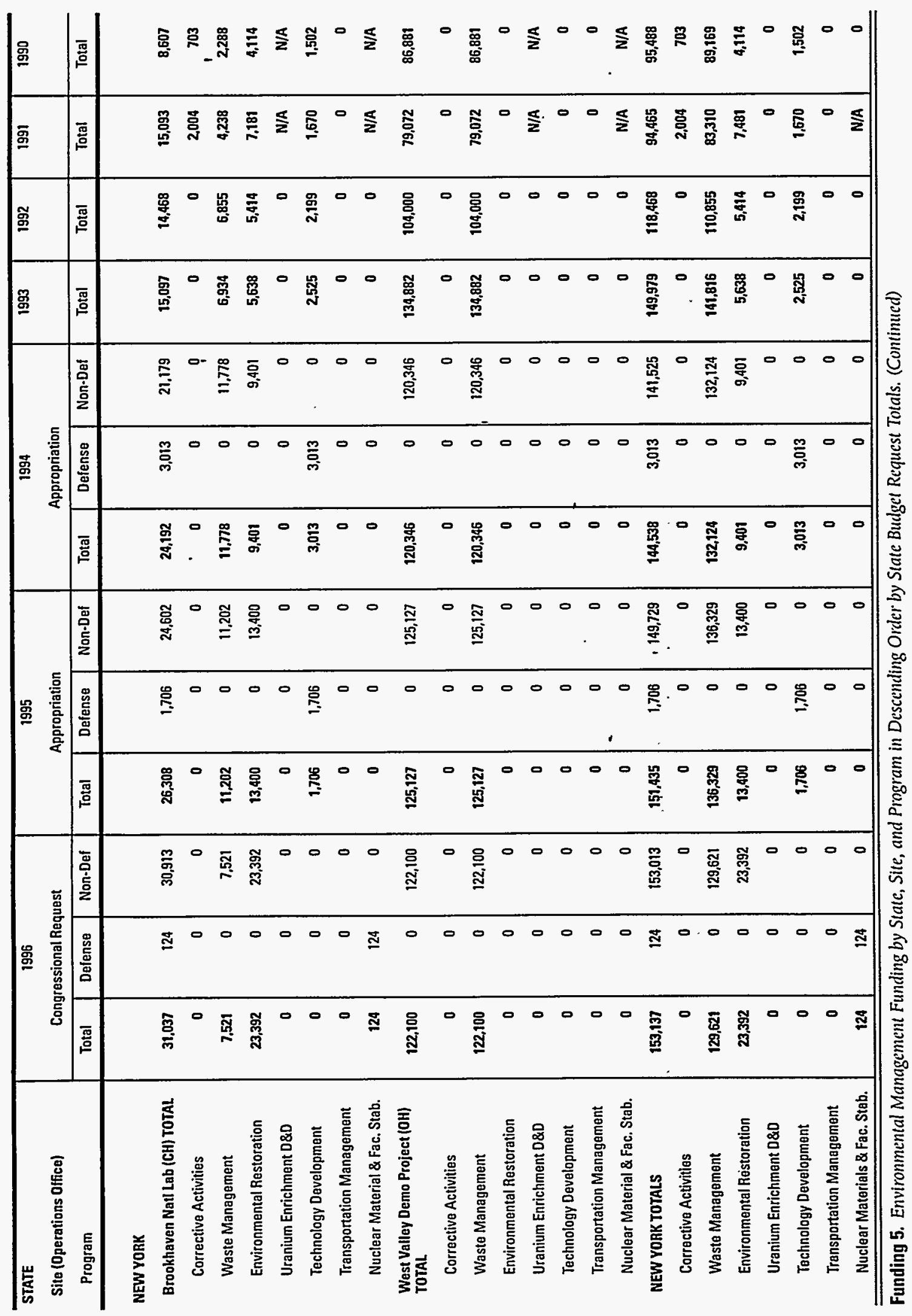




\begin{tabular}{|c|c|c|c|c|c|c|c|c|c|c|c|c|c|}
\hline \multirow{2}{*}{$\begin{array}{l}\text { STATE } \\
\text { Site (Operations Office) } \\
\text { Program }\end{array}$} & \multicolumn{3}{|c|}{$\begin{array}{c}1996 \\
\text { Congressional Request }\end{array}$} & \multicolumn{3}{|c|}{$\begin{array}{c}1995 \\
\text { Appropriation }\end{array}$} & \multicolumn{3}{|c|}{$\begin{array}{c}1994 \\
\text { Appropriation }\end{array}$} & \multirow{2}{*}{1993} & \multirow{2}{*}{$\begin{array}{l}1992 \\
\text { Total }\end{array}$} & \multirow{2}{*}{$\begin{array}{l}1991 \\
\text { Total }\end{array}$} & \multirow{2}{*}{$\begin{array}{l}1990 \\
\text { Total } \\
\end{array}$} \\
\hline & Total & Defense & Non-Def & Total & Defense & Non-Def & Total & Defense & Non-Def & & & & \\
\hline \multicolumn{14}{|l|}{ CALIFORNIA } \\
\hline SNL - Livermore (AL) TOTAL & 4,863 & 4,863 & 0 & 8,346 & 8,346 & 0 & 9,584 & 9,584 & 0 & 5,814 & 6,606 & 3,344 & 6,961 \\
\hline Corrective Activities & 0 & 0 & 0 & 0 & 0 & 0 & 0 & 0 & 8 & 0 & 755 & 280 & , 217 \\
\hline Waste Management & 2.159 & 2,159 & 0 & 2,261 & 2,261 & 0 & 2,216 & 2,216 & 0 & 2,234 & 1,522 & 1.200 & 2.266 \\
\hline Environmental Restoration & 2,704 & 2,704 & 0 & 4,244 & 4,244 & 0 & 4,448 & 4,448 & 0 & 3,580 & 4,329 & 1,864 & 173 \\
\hline Uranium Enrichment D\&D & 0 & 0 & 0 & 0 & 0 & 0 & 0 & 0 & 0 & 0 & 0 & $N / A$ & $N / A$ \\
\hline Technology Development & 0 & 0 & 0 & 1,841 & 1,841 & 0 & 2,920 & 2,920 & 0 & 0 & 0 & 0 & 0 \\
\hline Transportation Management & 0 & 0 & 0 & o & 0 & 0 & 0 & 0 & o & 0 & 0 & 0 & 4,305 \\
\hline Nuclear Material \& Fac. Stab. & 0 & 0 & 0 & o & 0 & $\mathbf{0}$ & 0 & 0 & 0 & 0 & 0 & N/A & N/A \\
\hline General Atomics (0ak) TOTAL. & 3,000 & o & 3,000 & 2,700 & 0 & 2,700 & 3,000 & 0 & 3,000 & 1.549 & 1.291 & 0 & 0 \\
\hline Corrective Activities & 0 & 0 & 0 & o & 0 & 0 & 0 & 0 & 0 & 0 & 0 & 0 & o \\
\hline Waste Management & 0 & 0 & 0 & $\mathbf{0}$ & 0 & 0 & 0 & o & $\mathbf{0}$ & 0 & 0 & o & 0 \\
\hline Environmental Restoration & 3,000 & 0 & 3,000 & 2,700 & 0 & 2,700 & 3,000 & 0 & 3,000 & 1,549 & 1,291 & 0 & 0 \\
\hline Uranium Enrichment D\&D & o & 0 & 0 & 0 & 0 & 0 & 0 & 0 & 0 & 0 & 0 & N/A & $N / A$ \\
\hline Technology Development & 0 & o & 0 & 0 & 0 & 0 & 0 & 0 & 0 & 0 & o & 0 & 0 \\
\hline Transportation Management & 0 & 0 & 0 & 0 & $\mathbf{0}$ & 0 & o & 0 & 0 & 0 & 0 & 0 & 0 \\
\hline Nuclear Material \& Fac. Stab. & 0 & 0 & 0 & 0 & 0 & 0 & 0 & 0 & 0 & o & 0 & N/A & N/A \\
\hline General Electric (Oak) TOTAL & 105 & 0 & 105 & 360 & 0 & 360 & 44 & 0 & 44 & 0 & 536 & 0 & o \\
\hline Corrective Activities & 0 & 0 & 0 & 0 & 0 & 0 & o & 0 & o & 0 & 0 & 0 & 0 \\
\hline Waste Management & 0 & 0 & 0 & 0 & 0 & 0 & o & 0 & 0 & o & 0 & 0 & 0 \\
\hline Environmental Restoration & 105 & 0 & 105 & 360 & 0 & 360 & 44 & 0 & 44 & 0 & 536 & 0 & 0 \\
\hline Uranium Enrichment D\&D & 0 & 0 & 0 & 0 & 0 & 0 & 0 & 0 & 0 & 0 & 0 & N/A & $N / A$ \\
\hline Technology Development & 0 & 0 & 0 & 0 & 0 . & 0 & 0 & $\mathbf{0}$ & 0 & 0 & 0 & o & 0 \\
\hline Transportation Management & 0 & 0 & 0 & 0 & 0 & 0 & o & o & 0 & 0 & o & 0 & 0 \\
\hline Nuclear Material \& Fac. Stab. & 0 & o & 0 & 0 & 0 & 0 & 0 & 0 & 0 & 0 & 0 & N/A & N/A \\
\hline
\end{tabular}

Funding 5. Environmental Management Funding by State, Sitc, and Progrem in Descending Order by State Budget Request Totals. (Comtinucel) 


\begin{tabular}{|c|c|c|c|c|c|c|c|c|c|c|c|c|c|}
\hline \multirow{2}{*}{$\begin{array}{l}\text { STATE } \\
\text { Site (Operations Office) } \\
\text { Program }\end{array}$} & \multicolumn{3}{|c|}{$\begin{array}{c}1996 \\
\text { Congressional Request }\end{array}$} & \multicolumn{3}{|c|}{$\begin{array}{c}1995 \\
\text { Appropriation }\end{array}$} & \multicolumn{3}{|c|}{$\begin{array}{c}1994 \\
\text { Appropriation }\end{array}$} & \multirow{2}{*}{1993} & \multirow{2}{*}{$\begin{array}{l}1992 \\
\text { Total }\end{array}$} & \multirow{2}{*}{$\begin{array}{l}1991 \\
\text { Total }\end{array}$} & \multirow{2}{*}{$\begin{array}{l}1990 \\
\text { Total }\end{array}$} \\
\hline & Total & Defense & Non-Def & Total & Defense & Non-Def & Total & Defense & Non-Def & & & & \\
\hline $\begin{array}{l}\text { Lawrence Berkeley Lab (0ak) } \\
\text { TOTAL }\end{array}$ & 12,508 & 0 & 12,508 & 15,902 & 2,000 & 13,902 & 19,159 & 1,860 & 17,299 & 10,367 & 14,289 & 6,133 & 2,972 \\
\hline Corrective Activities & 0 & 0 & 0 & 0 & 0 & 0 & 0 & 0 & 0 & 0 & 4,180 & 2.015 & 100 \\
\hline Waste Management & 7,102 & 0 & 7,102 & 9,980 & $\mathbf{0}$ & 9,980 & 14,030 & 0 & 14,030 & 6,383 & 8,167 & 0 & 2,307 \\
\hline Environmental Restoration & 4,160 & 0 & 4,160 & 3,922 & 0 & 3,922 & 3,269 & 0 & 3,269 & 2,953 & 1,537 & 4,118 & 0 \\
\hline Uranium Enrichment D\&D & 0 & 0 & 0 & 0 & 0 & 0 & 0 & 0 & 0 & 0 & 0 & N/A & $N / A$ \\
\hline Technology Development & 0 & 0 & 0 & 2,000 & 2,000 & 0 & 1,860 & 1,860 & 0 & 1,031 & 405 & 0 & 565 \\
\hline Transportation Management & 0 & 0 & 0 & 0 & 0 & 0 & 0 & 0 & 0 & 0 & 0 & 0 & 0 \\
\hline Nuclear Material \& Fac. Stab. & 1,246 & 0 & 1,246 & 0 & 0 & 0 & 0 & 0 & 0 & 0 & 0 & N/A & N/A \\
\hline Lawrence Livermore (Oak) TOTAL & 77,933 & 77,933 & 0 & 76,227 & 76,227 & 0 & 92,276 & 92,276 & o & 107,648 & 77,803 & 52,748 & 33,829 \\
\hline Corrective Activities & 0 & 0 & 0 & 512 & 512 & 0 & 4,058 & 4,058 & 0 & 15,700 & 15,955 & 255 & 1,123 \\
\hline Waste Management & 52,433 & 52,433 & 0 & 44,088 & 44,088 & 0 & 49,508 & 49,508 & 0 & 42,030 & 21,089 & 16,153 & 9,963 \\
\hline Environmental Restoration & 25,500 & 25,500 & 0 & 26,000 & 26,000 & 0 & 29,204 & 29,204 & 0 & 30,996 & 25,024 & 21,113 & 17.445 \\
\hline Uranium Enrichment D\&D & 0 & 0 & 0 & 0 & 0 & 0 & 0 & 0 & 0 & 0 & 0 & N/A & N/A \\
\hline Technology Development & 0 & 0 & 0 & 5,627 & 5,627 & 0 & 9,505 & 9,506 & 0 & 18,922 & 15,735 & 15,227 & 5,298 \\
\hline Transportation Management & 0 & 0 & 0 & 0 & 0 & 0 & 0 & 0 & 0 & 0 & 0 & 0 & 0 \\
\hline Nuclear Material \& Fac. Stab. & 0 & 0 & 0 & 0 & 0 & 0 & 0 & 0 & 0 & 0 & 0 & N/A & $N / A$ \\
\hline $\begin{array}{l}\text { Energy Tech Eng. Center (Oak) } \\
\text { TOTAL }\end{array}$ & 8,135 & 1,000 & 7,135 & 10,075 & 2,455 & 7,620 & 7,044 & 1,572 & 5,472 & 10,602 & 13,646 & 10,828 & 4,707 \\
\hline Corrective Activities & 0 & 0 & 0 & 0 & 0 & 0 & 0 & 0 & 0 & 0 & 25 & 3,087 & 0 \\
\hline Waste Management & 3.063 & 0 & 3,063 & 4,380 & 0 & 4,380 & 2,120 & 0 & 2,120 & 1,397 & 781 & 1,135 & 0 \\
\hline Environmental Restoration & 4,400 & 1,000 & 3,400 & 4,320 & 1,080 & 3,240 & 4,624 & 1,272 & 3,352 & 8,840 & 12,650 & 6,606 & 4,707 \\
\hline Uranium Enrichment D\&D & 0 & 0 & 0 & $\mathbf{0}$ & 0 & 0 & $\mathbf{0}$ & 0 & 0 & 0 & 0 & N/A & N/A \\
\hline Technology Development & 0 & 0 & 0 & 1,375 & 1,375 & 0 & 300 & 300 & 0 & 365 & 190 & 0 & 0 \\
\hline Transportation Management & 0 & 0 & 0 & 0 & 0 & 0 & 0 & 0 & 0 & 0 & o & 0 & 0 \\
\hline Nuclear Material \& Fac. Stab. & 672 & 0 & 672 & 0 & 0 & 0 & 0 & 0 & 0 & o & 0 & N/A & N/A \\
\hline
\end{tabular}

Funding 5. Environmental Menagement Funding by State, Sitc, and Program in Descending Order by State Budget Request Totals. (Continued) 


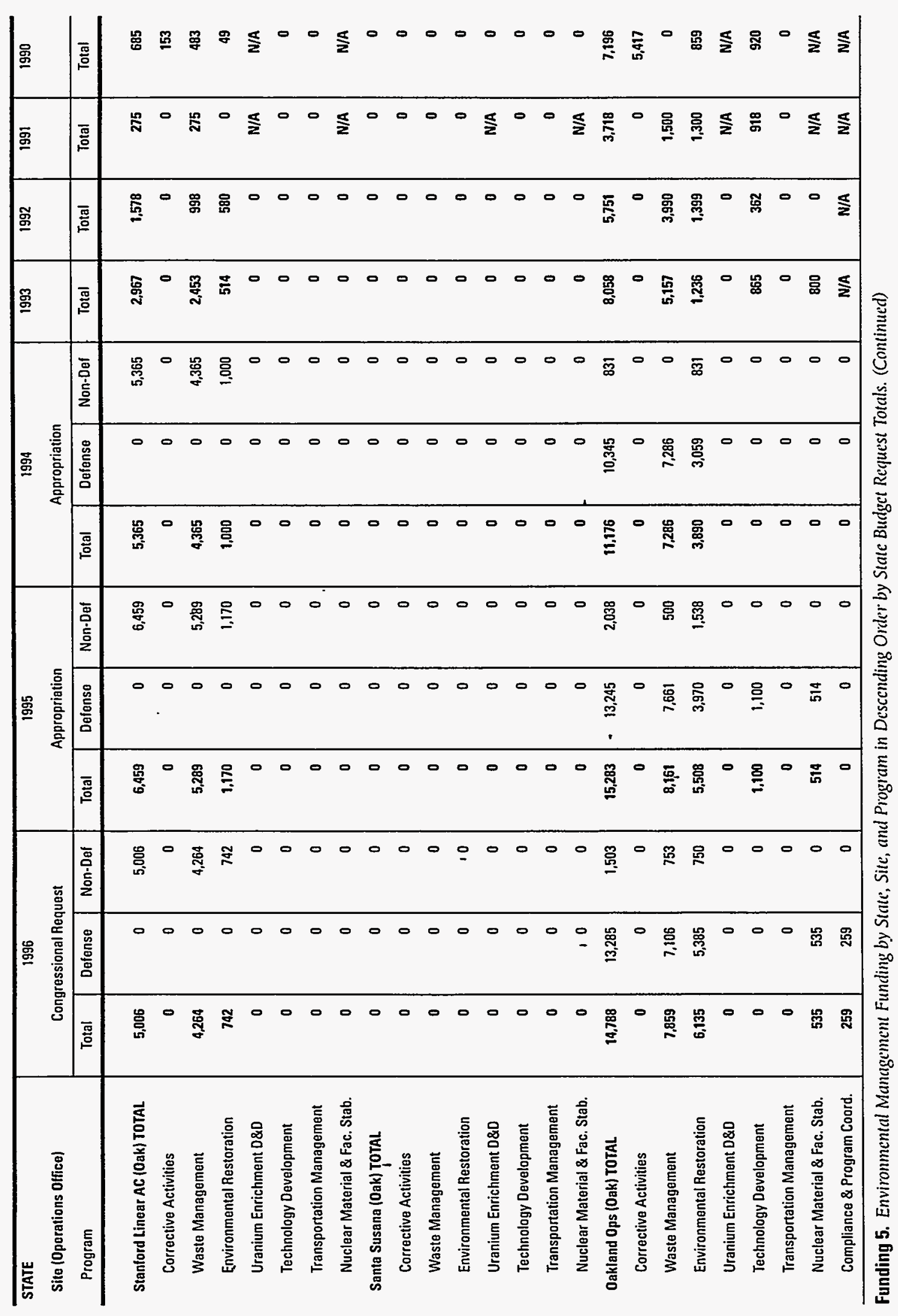




\begin{tabular}{|c|c|c|c|c|c|c|c|c|c|c|c|c|c|}
\hline \multirow{2}{*}{$\begin{array}{l}\text { STATE } \\
\text { Site (Operations Office) } \\
\text { Program }\end{array}$} & \multicolumn{3}{|c|}{$\begin{array}{c}1996 \\
\text { Congressional Request }\end{array}$} & \multicolumn{3}{|c|}{$\begin{array}{c}1995 \\
\text { Appropriation }\end{array}$} & \multicolumn{3}{|c|}{$\begin{array}{c}1994 \\
\text { Appropriation }\end{array}$} & \multirow{2}{*}{$\begin{array}{l}1993 \\
\text { Total } \\
\end{array}$} & \multirow{2}{*}{$\begin{array}{c}1992 \\
\text { Total }\end{array}$} & \multirow{2}{*}{$\begin{array}{l}1991 \\
\text { Total }\end{array}$} & \multirow{2}{*}{$\begin{array}{l}1990 \\
\text { Total } \\
\end{array}$} \\
\hline & Total & Defense & Non-Def & Total & Delense & Non-Def & Total & Defense & Non-Def & & & & \\
\hline U.C. Davis (Dak) TOTAL & 4,730 & 0 & 4,730 & 4,057 & 0 & 4,057 & 6,541 & 0 & 6,541 & 6,207 & 5,890 & 1,107 & 1.481 \\
\hline Corrective Activities & 0 & 0 & 0 & 0 & 0 & 0 & 0 & 0 & 0 & 0 & 0 & 0 & 0 \\
\hline Waste Management & 0 & 0 & 0 & 0 & 0 & 0 & 0 & 0 & 0 & 0 & 0 & 0 & 0 \\
\hline Environmental Restoration & 4,730 & 0 & 4,730 & 4,057 & 0 & 4,057 & 6,541 & 0 & 6,541 & 6,207 & 5,890 & 1,107 & 1.481 \\
\hline Uranium Enrichment D\&D & 0 & 0 & o & 0 & 0 & 0 & 0 & 0 & 0 & 0 & 0 & $N / A$ & N/A \\
\hline Technology Development & 0 & 0 & 0 & 0 & 0 & 0 & 0 & 0 & 0 & 0 & 0 & 0 & 0 \\
\hline Transportation Management & 0 & 0 & 0 & 0 & 0 & 0 & 0 & 0 & 0 & 0 & 0 & 0 & 0 \\
\hline Nuclear Material \& Fac. Stab. & 0 & 0 & 0 & 0 & 0 & 0 & 0 & 0 & 10 & 0 & 0 & N/A & N/A \\
\hline CALIFORNIA TOTALS & 131,068 & 97,081 & 33,987 & 139,409 & 102,273 & 37,136 & 154,189 & 115,637 & 38,552 & 153,212 & 127,390 & 78,153 & 57,831 \\
\hline Corrective Activities & 0 & 0 & 0 & 512 & 512 & 0 & 4,058 & 4,058 & 0 & 15,700 & 20,915 & 5,637 & 7,010 \\
\hline Waste Management & 76,880 & 61,698 & 15,182 & 74,159 & 54,010 & 20,149 & 79,525 & 59,010 & 20,515 & 59,654 & 36,547 & 20,263 & 15,019 \\
\hline Environmental Restoration & 51,476 & 34,589 & 16,887 & 52,281 & 35,294 & 16,987 & 56,020 & 37,983 & 18,037 & 55,875 & 53,236 & 36,108 & 24,714 \\
\hline Uranium Enrichment D\&D & 0 & 0 & 0 & 0 & 0 & 0 & 0 & 0 & 0 & 0 & 0 & N/A & 0 \\
\hline Technology Development & 0 & 0 & 0 & 11,943 & 11,943 & 0 & 14,586 & 14,586 & 0 & 21,183 & 16,692 & 16,145 & 6,783 \\
\hline Transportation Management & 0 & 0 & 0 & 0 & 0 & 0 & 0 & 0 & 0 & 0 & 0 & 0 & 4,305 \\
\hline Nuclear Materials \& Fac. Stab. & 2,453 & 535 & 1,918 & 514 & 514 & 0 & 0 & 0 & 0 & 800 & 0 & N/A & 0 \\
\hline Compliance \& Program Coord. & 259 & 259 & 0 & 0 & 0 & 0 & 0 & 0 & 0 & N/A & N/A & N/A & $\mathbf{0}$ \\
\hline \multicolumn{14}{|l|}{ MISSOURI } \\
\hline ANL - Weldon (CH) TOTAL & 0 & 0 & 0 & 0 & 0 & 0 & 0 & 0 & 0 & 1.400 & 2,314 & 1,930 & N/A \\
\hline Corrective Activities & $\mathbf{0}$ & 0 & 0 & 0 & 0 & 0 & 0 & 0 & 0 & 0 & 0 & 0 & N/A \\
\hline Waste Management & 0 & 0 & 0 & $\mathbf{0}$ & o & 0 & 0 & 0 & 0 & 0 & 0 & 0 & $N / A$ \\
\hline Environmental Restoration & 0 & 0 & 0 & 0 & 0 & 0 & 0 & 0 & 0 & 1.400 & 2,314 & 1.930 & N/A \\
\hline Uranium Enrichment D\&D & 0 & 0 & 0 & 0 & 0 & 0 & 0 & 0 & 0 & 0 & o & N/A & N/A \\
\hline Technology Development & o & 0 & 0 & 0 & 0 & 0 & 0 & 0 & 0 & 0 & 0 & $\mathbf{0}$ & $N / A$ \\
\hline Transportation Management & 0 & 0 & 0 & 0 & 0 & 0 & 0 & 0 & 0 & 0 & 0 & 0 & $N / A$ \\
\hline Nuclear Material \& Fac. Stab. & 0 & 0 & 0 & 0 & 0 & 0 & 0 & 0 & 0 & 0 & 0 & N/A & $N / A$ \\
\hline
\end{tabular}

Funding 5. Environmental Management Funding by State, Site, and Program in Descending Order by State Budget Request Totals. (Comtinued) 


\begin{tabular}{|c|c|c|c|c|c|c|c|c|c|c|c|c|c|}
\hline \multirow{2}{*}{$\begin{array}{l}\text { STATE } \\
\text { Sito (Oporations Office) } \\
\text { Program }\end{array}$} & \multirow{2}{*}{\multicolumn{3}{|c|}{\begin{tabular}{l|l|l}
\multicolumn{3}{c}{1996} \\
\multicolumn{2}{c}{ Congressional Request } \\
Total & Defense & Non-Def
\end{tabular}}} & \multirow{2}{*}{\multicolumn{3}{|c|}{\begin{tabular}{l}
\multicolumn{2}{c|}{1995} \\
Appropriation \\
\begin{tabular}{|c|c|} 
Defense & Non-Def \\
\end{tabular}
\end{tabular}}} & \multicolumn{3}{|c|}{$\begin{array}{c}1994 \\
\text { Appropriation }\end{array}$} & \multirow{2}{*}{$\begin{array}{l}1993 \\
\text { Total } \\
\end{array}$} & \multirow{2}{*}{1992} & \multirow{2}{*}{$\begin{array}{l}1991 \\
\text { Total } \\
\end{array}$} & \multirow{2}{*}{$\frac{1990}{\text { Total }}$} \\
\hline & & & & & & & Total & Defense & Non-Def & & & & \\
\hline Kansas City Plant (AL) TOTAL & 12,389 & 12,389 & 0 & 11,215 & 11,215 & 0 & 12,657 & 12,657 & 0 & 16,895 & 27,528 & 17,359 & 12,047 \\
\hline Corrective Activities & 0 & 0 & 0 & 0 & 0 & 0 & 0 & 0 & 0 & 2.791 & 4.140 & 5.549 & 4.172 \\
\hline Waste Management & 6,067 & 6,067 & 0 & 7,645 & 7,645 & 0 & 7,105 & 7,105 & 0 & 6,529 & 7,326 & 4,785 & 4,661 \\
\hline Environmental Restoration & 6,322 & 6,322 & 0 & 3,570 & 3,570 & 0 & 5.552 & 5,552 & 0 & 7,381 & 14,867 & 5,115 & 2,684 \\
\hline Uranium Enrichment D\&D & 0 & 0 & 0 & 0 & 0 & 0 & 0 & 0 & 0 & 0 & 0 & N/A & N/A \\
\hline Technology Development & 0 & 0 & 0 & 0 & 0 & 0 & 0 & 0 & 0 & 194 & 1,195 & 1.910 & 530 \\
\hline Transportation Management & 0 & 0 & 0 & 0 & o & 0 & 0 & 0 & 0 & 0 & 0 & 0 & 0 \\
\hline Nuclear Material \& Fac. Stab. & 0 & 0 & 0 & 0 & 0 & 0 & 0 & 0 & 0 & 0 & 0 & N/A & N/A \\
\hline Weldon (OB) TOTAL & 67,500 & 0 & 67,500 & 53,198 & $\mathbf{0}$ & 53,198 & 39,702 & 0 & 39,702 & 69,782 & 43,068 & 25,402 & 9,837 \\
\hline Corrective Activities & 0 & 0 & 0 & 0 & 0 & 0 & 0 & 0 & 0 & 0 & 0 & 0 & 0 \\
\hline Waste Management & 0 & 0 & 0 & 0 & 0 & 0 & 0 & 0 & 0 & 0 & 0 & 0 & 0 \\
\hline Environmental Restoration & 67,500 & 0 & 67,500 & 53,198 & 0 & 53,198 & 39,702 & 0 & 39,702 & 69.782 & 43,068 & 25,402 & 9,837 \\
\hline Uranium Enrichment D\&D & 0 & 0 & 0 & 0 & 0 & 0 & 0 & 0 & 0 & 0 & 0 & N/A & N/A \\
\hline Technology Development & 0 & 0 & 0 & 0 & 0 & 0 & 0 & 0 & 0 & 0 & 0 & 0 & 0 \\
\hline Transportation Management & 0 & 0 & 0 & 0 & 0 & 0 & 0 & 0 & 0 & 0 & 0 & 0 & 0 \\
\hline Nuclear Material \& Fac. Stab. & 0 & 0 & 0 & 0 & 0 & 0 & 0 & 0 & 0 & 0 & 0 & N/A & N/A \\
\hline MISSOURI TOTALS & 79,889 & 12,389 & 67,500 & 64,413 & 11,215 & 53,198 & 52,359 & 12,657 & 39,702 & 88,077 & 72,910 & 44,691 & 21,884 \\
\hline Corrective Activititis & 0 & 0 & 0 & 0 & 0 & 0 & 0 & 0 & 0 & 2,791 & 4,140 & 5,549 & 4,172 \\
\hline Waste Management & 6,067 & 6,067 & 0 & 7,645 & 7,645 & 0 & 7,05 & 7,105 & 0 & 6,529 & 7,326 & 4.785 & 4,661 \\
\hline Environmental Restoration & 73,822 & 6,322 & 67,500 & 56,768 & 3,570 & 53,198 & 45,254 & 5,552 & 39,702 & 78,563 & 60,249 & 32,447 & 12,521 \\
\hline Uranium Enrichment D\&D & 0 & 0 & 0 & 0 & 0 & 0 & 0 & 0 & 0 & 0 & 0 & N/A & 0 \\
\hline Technology Development & 0 & 0 & 0 & 0 & 0 & 0 & 0 & 0 & 0 & 194 & 1,195 & 1.910 & 530 \\
\hline Transportation Management & 0 & 0 & 0 & 0 & 0 & 0 & 0 & 0 & 0 & 0 & 0 & 0 & 0 \\
\hline Nuclear Materials \& Fac. Stab. & 0 & 0 & 0 & 0 & 0 & 0 & 0 & 0 & 0 & 0 & 0 & N/A & 0 \\
\hline
\end{tabular}

Funding 5. Envirommental Management Funding by State, Sitc, and Program in Descending Order by State Budget Request Totals. (Continued) 


\begin{tabular}{|c|c|c|c|c|c|c|c|c|c|c|c|c|c|}
\hline \multirow{2}{*}{$\begin{array}{l}\text { STATE } \\
\text { Site (Operations Office) } \\
\text { Program }\end{array}$} & \multicolumn{3}{|c|}{$\begin{array}{c}1996 \\
\text { Congressional Request }\end{array}$} & \multicolumn{3}{|c|}{$\begin{array}{c}1995 \\
\text { Appropriation }\end{array}$} & \multicolumn{3}{|c|}{$\begin{array}{c}1994 \\
\text { Appropriation }\end{array}$} & \multirow{2}{*}{$\begin{array}{l}1993 \\
\text { Total } \\
\end{array}$} & \multirow{2}{*}{$\begin{array}{l}1992 \\
\text { Total } \\
\end{array}$} & \multirow{2}{*}{$\begin{array}{l}1991 \\
\text { Total } \\
\end{array}$} & \multirow{2}{*}{$\begin{array}{l}1990 \\
\text { Total }\end{array}$} \\
\hline & Total & Defense & Non-Def & Total & Defense & Non-Def & Total & Defense & Non-Del & & & & \\
\hline \multicolumn{14}{|l|}{ NEVADA } \\
\hline Nevada OH-Sito (NV) TOTAL & 0 & 0 & 0 & 0 & 0 & 0 & 0 & o & o & N/A & N/A & 0 & 3,094 \\
\hline Corrective Activities & 0 & 0 & 0 & 0 & 0 & 0 & 0 & 0 & 0 & N/A & N/A & 0 & N/A \\
\hline Waste Management & 0 & 0 & 0 & 0 & 0 & 0 & 0 & 0 & 0 & N/A & N/A & 0 & 246 \\
\hline Environmental Restoration & 0 & 0 & 0 & 0 & 0 & 0 & 0 & 0 & 0 & N/A & N/A & $\mathbf{0}$ & 135 \\
\hline Uranium Enrichment D\&D & 0 & 0 & 0 & 0 & o & 0 & 0 & 0 & 0 & N/A & N/A & N/A & N/A \\
\hline Technology Development & 0 & 0 & 0 & 0 & 0 & $0^{\circ}$ & 0 & 0 & 0 & N/A & N/A & 0 & 2,663 \\
\hline Transportation Management & 0 & 0 & D & 0 & 0 & 0 & 0 & 0 & 0 & N/A & N/A & 0 & 50 \\
\hline Nuclear Material \& Fac. Stab. & o & 0 & 0 & 0 & 0 & o & 0 & 0 & 0 & N/A & N/A & N/A & N/A \\
\hline Nevada Test Site (NV) TOTAL & 21,729 & 21,729 & 0 & 22,980 & 22,980 & 0 & 17,955 & 17,955 & 0 & 20,732 & 13,703 & $N / A$ & 12,993 \\
\hline Corrective Activities & 0 & 0 & 0 & 0 & 0 & 0 & 0 & 0 & 0 & $\mathbf{0}$ & 0 & N/A & 1,737 \\
\hline Waste Management & 21,729 & 21,729 & 0 & 22,980 & 22,980 & 0 & 17,955 & 17,955 & 0 & 20,732 & 13,703 & N/A & 3,315 \\
\hline Environmental Restoration & 0 & 0 & 0 & 0 & 0 & 0 & 0 & 0 & 0 & 0 & 0 & N/A & 7,941 \\
\hline Uranium Enrichment D\&D & $\mathbf{0}$ & 0 & 0 & 0 & 0 & 0 & 0 & 0 & 0 & 0 & 0 & N/A & N/A \\
\hline Technology Development & 0 & 0 & o & 0 & 0 & 0 & 0 & 0 & 0 & 0 & 0 & $N / A$ & 0 \\
\hline Transportation Management & $\mathbf{0}$ & 0 & 0 & 0 & 0 & 0 & $0^{*}$ & 0 & 0 & o & 0 & $N / A$ & $\mathbf{0}$ \\
\hline Nuclear Material \& Fac. Stab. & 0 & 0 & 0 & 0 & 0 & 0 & 0 & 0 & 0 & 0 & 0 & $N / A$ & N/A \\
\hline Nevada Ops (NV) TOTAL & 54,514 & 54,514 & 0 & 41,555 & 41,555 & 0 & 54,078 & 54,078 & 0 & 49,946 & 34,394 & 29,062 & 2,739 \\
\hline Corrective Activities & o & 0 & 0 & 0 & 0 & o & 0 & 0 & 0 & 0 & 1,910 & 836 & o \\
\hline Waste Management & 3,059 & 3,059 & 0 & 1,678 & 1,678 & 0 & 950 & 950 & .0 & 725 & 0 & 8,606 & 2,739 \\
\hline Environmental Restoration & 49,671 & 49.671 & 0 & 34,605 & 34,605 & 0 & 47,503 & 47,503 & 0 & 42,029 & 24,649 & 13,991 & N/A \\
\hline Uranium Enrichment D\&D & 0 & 0 & 0 & 0 & 0 & 0 & 0 & 0 & 0 & 0 & 0 & $N / A$ & N/A \\
\hline Technology Development & $\mathbf{0}$ & 0 & 0 & 5,272 & 5,272 & 0 & 5,595 & 5,595 & 0 & 7.158 & 7,687 & 5,379 & N/A \\
\hline Transportation Management & 0 & 0 & 0 & 0 & 0 & 0 & 30 & 30 & 0 & 34 & 148 & 250 & N/A \\
\hline Nuclear Material \& Fac. Stab. & 0 & 0 & 0 & 0 & 0 & 0 & 0 & 0 & 0 & 0 & D & $N / A$ & $N / A$ \\
\hline Compliance \& Program Coord. & 1,784 & 1,784 & 0 & 0 & 0 & 0 & 0 & 0 & 0 & N/A & N/A & N/A & N/A \\
\hline
\end{tabular}

Funding 5. Environmental Management Funding by State, Site, and Program in Descending Order by State Budget Request Totals. (Continued) 


\begin{tabular}{|c|c|c|c|c|c|c|c|c|c|c|c|c|c|}
\hline \multirow{2}{*}{$\begin{array}{l}\text { STATE } \\
\text { Sito (Oporations Office) } \\
\text { Program }\end{array}$} & \multicolumn{3}{|c|}{$\begin{array}{c}1996 \\
\text { Congressional Request }\end{array}$} & \multicolumn{3}{|c|}{$\begin{array}{c}1995 \\
\text { Appropriation }\end{array}$} & \multicolumn{3}{|c|}{$\begin{array}{c}1994 \\
\text { Appropriation }\end{array}$} & \multirow{2}{*}{$\begin{array}{l}1993 \\
\text { Total }\end{array}$} & \multirow{2}{*}{$\begin{array}{l}1992 \\
\text { Total }\end{array}$} & \multirow{2}{*}{$\begin{array}{l}1991 \\
\text { Total }\end{array}$} & \multirow{2}{*}{$\begin{array}{l}1990 \\
\text { Total }\end{array}$} \\
\hline & Total & Defense & Non-Def & Total & Defense & Non-Def & Total & Defense & Non-Def & & & & \\
\hline NEVADA TOTALS & 76,243 & 76,243 & 0 & 64.535 & 64,535 & 0 & 72,033 & 72,033 & 0 & 70,678 & 48,097 & 29,062 & 18,826 \\
\hline Correctivo Activities & 0 & 0 & 0 & 0 & 0 & 0 & 0 & 0 & 0 & 0 & 1,910 & 836 & 1.737 \\
\hline Waste Management & 24,788 & 24,788 & 0 & 24,658 & 24,658 & 0 & 18,905 & 18,905 & 0 & 21,457 & 13,703 & 8,606 & 6,300 \\
\hline Environmental Restoration & 49,671 & 49,671 & 0 & 34,605 & 34,605 & 0 & 47,503 & 47,503 & 0 & 42,029 & 24,649 & 13,991 & 8,076 \\
\hline Uranium Enrichment D\&D & $\mathbf{0}$ & 0 & 0 & 0 & 0 & 0 & 0 & 0 & 0 & 0 & 0 & N/A & 0 \\
\hline Technology Devolopment & 0 & 0 & 0 & 5,272 & 5,272 & 0 & $\mathbf{5 . 5 9 5}$ & 5,595 & 0 & 7,158 & 7,687 & 5,379 & 2,663 \\
\hline Transpartation Management & 0 & 0 & 0 & 0 & 0 & 0 & 30 & 30 & 0 & 34 & 148 & 250 & 50 \\
\hline Nuclaar Materials \& Fac. Stab. & 0 & 0 & 0 & 0 & 0 & 0 & 0 & 0 & 0 & 0 & 0 & N/A & 0 \\
\hline Compliance \& Program Coord. & 1,784 & 1.784 & 0 & 0 & 0 & 0 & 0 & 0 & 0 & N/A & N/A & N/A & 0 \\
\hline \multicolumn{14}{|l|}{ KENTUCKY } \\
\hline Paducah GDP (OR) TOTAL & 56,012 & 0 & 56,012 & 53,512 & 1,212 & 52,300 & 36,542 & 9,165 & 27,377 & 25,691 & 7,683 & 0 & o \\
\hline Corrective Activities & 0 & 0 & 0 & 0 & 0 & 0 & 0 & 0 & 0 & 0 & 0 & 0 & 0 \\
\hline Waste Management & 0 & 0 & 0 & 0 & 0 & 0 & 0 & 0 & 0 & 0 & 0 & 0 & 0 \\
\hline Environmental Restoration & 0 & 0 & 0 & 1,212 & 1,212 & 0 & 9,165 & 9,165 & 0 & 25,691 & 7,683 & 0 & 0 \\
\hline Uranium Enrichment D\&D & 56,012 & 0 & 56,012 & 52,300 & 0 & 52,300 & 27,377 & 0 & 27,377 & 0 & 0 & N/A & N/A \\
\hline Technology Development & 0 & 0 & 0 & 0 & 0 & 0 & 0, & 0 & 0 & 0 & 0 & 0 & 0 \\
\hline Transportation Management & 0 & 0 & 0 & 0 & 0 & 0 & 0 & 0 & 0 & 0 & 0 & 0 & 0 \\
\hline Nuclear Material \& Fac. Stab. & 0 & 0 & 0 & $\mathbf{0}$ & 0 & 0 & $\mathbf{0}$ & 0 & 0 & 0 & 0 & N/A & N/A \\
\hline \multicolumn{14}{|l|}{ FLORIDA } \\
\hline Pinellas Plant (AL) TOTAL & 52,621 & 52,621 & 0 & 7,715 & 7,715 & 0 & 7.276 & 7,276 & 0 & 9,208 & 4,603 & 4,744 & 2,993 \\
\hline Corrective Activities & 0 & 0 & 0 & 0 & 0 & 0 & 0 & 0 & 0 & 0 & 0 & 0 & 256 \\
\hline Waste Management & 2,269 & 2,269 & 0 & 2,537 & 2,537 & 0 & 2,569 & 2,569 & 0 & 2,163 & 1,751 & 1,558 & 1,704 \\
\hline Environmental Restoration & 4,000 & 4,000 & 0 & 4,829 & 4,829 & 0 & 4,707 & 4,707 & 0 & 6,245 & 2,852 & 3,186 & 1,033 \\
\hline Uranium Enrichment D\&D & 0 & 0 & 0 & 0 & 0 & 0 & 0 & 0 & 0 & 0 & 0 & N/A & N/A \\
\hline Technology Development & o & 0 & 0 & 0 & 0 & 0 & 0 & 0 & 0 & 0 & 0 & 0 & 0 \\
\hline Transportation Management & o & 0 & 0 & 0 & 0 & 0 & 0 & 0 & 0 & o & 0 & 0 & 0 \\
\hline Nuclear Material \& Fac. Stab. & 46,352 & 46,352 & 0 & 349 & 349 & 0 & 0 & 0 & 0 & 800 & 0 & N/A & N/A \\
\hline
\end{tabular}

Funding 5. Envirommental Management Funding by Stutc, Sitc, and Program in Descending Order by Stete Budget Request Totals. (Contimued) 


\begin{tabular}{|c|c|c|c|c|c|c|c|c|c|c|c|c|c|}
\hline \multirow{2}{*}{$\begin{array}{l}\text { STATE } \\
\text { Site (Operations Office) } \\
\text { Program }\end{array}$} & \multicolumn{3}{|c|}{$\begin{array}{c}1996 \\
\text { Congressional Request }\end{array}$} & \multicolumn{3}{|c|}{$\begin{array}{c}1995 \\
\text { Appropriation }\end{array}$} & \multicolumn{3}{|c|}{$\begin{array}{c}1994 \\
\text { Appropriation }\end{array}$} & \multirow{2}{*}{$\begin{array}{l}1993 \\
\text { Total } \\
\end{array}$} & \multirow{2}{*}{1992} & \multirow{2}{*}{$\begin{array}{l}1991 \\
\text { Total } \\
\end{array}$} & \multirow{2}{*}{$\begin{array}{l}1990 \\
\text { Total } \\
\end{array}$} \\
\hline & Total & Defense & Non-Def & Total & Defense & Non-Def & Total & Defense & Non-Def & & & & \\
\hline \multicolumn{14}{|l|}{ ILINOIS } \\
\hline ANL - East (CH) TOTAL & 19,586 & 933 & 18,653 & 38,797 & 13,253 & 25,544 & 42,258 & 16,175 & 26,083 & 50,421 & 35,963 & 29,420 & 19,578 \\
\hline Corrective Activities & 0 & 0 & 0 & 0 & 0 & 0 & 780 & , 0 & 780 & 2,002 & 8,235 & 7.447 & 2.168 \\
\hline Waste Management & 13,551 & 407 & 13,144 & 16,390 & 246 & 16.144 & 15,563 & 300 & 15,263 & 22,940 & 11,758 & 8,745 & 9,916 \\
\hline Environmental Restoration & 5,509 & 0 & 5,509 & 9,400 & 0 & 9,400 & 10,040 & .0 & 10,040 & 13,416 & 4,768 & 9,724 & 7,494 \\
\hline Uranium Enrichment D\&D & o & 0 & 0 & 0 & 0 & 0 & 0 & 0 & 0 & 0 & 0 & N/A & N/A \\
\hline Technology Development & 0 & 0 & 0 & 12,238 & 12,238 & 0 & 14,875 & 14,875 & 0 & 11,706 & 10,782 & 3,216 & 0 \\
\hline Transportation Management & 382 & 382 & 0 & 769 & 769 & 0 & 1,000 & 1,000 & 0 & 357 & 420 & 288 & 0 \\
\hline Nuclear Material \& Fac. Stab. & 144 & 144 & 0 & 0 & 0 & 0 & 0 & 0 & 0 & 0 & $\mathbf{0}$ & N/A & N/A \\
\hline FUSRAP - ANL (CH) TOTAL & 0 & 0 & 0 & 0 & 0 & 0 & 0 & 0 & 0 & 0 & 0 & 1.700 & 0 \\
\hline Corrective Activities & 0 & 0 & 0 & 0 & 0 & 0 & 0 & 0 & 0 & 0 & $\mathbf{0}$ & o & o \\
\hline Waste Management & $\mathbf{0}$ & 0 & 0 & 0 & 0 & 0 & 0 & 0 & 0 & 0 & 0 & 0 & 0 \\
\hline Environmental Restoration & 0 & 0 & 0 & 0 & 0 & 0 & 0 & 0 & 0 & 0 & 0 & 1,700 & o \\
\hline Uranium Enrichment D\&D & 0 & 0 & 0 & 0 & 0 & 0 & 0 & 0 & 0 & 0 & 0 & N/A & N/A \\
\hline Technology Development & o & 0 & 0 & o & 0 & 0 & 0 & 0 & 0 & 0 & $\mathbf{0}$ & 0 & 0 \\
\hline Transportation Management & 0 & 0 & 0 & 0 & 0 & 0 & 0 & 0 & 0 & 0 & 0 & $\mathbf{0}$ & 0 \\
\hline Nuclear Material \& Fac. Stab. & 0 & 0 & o & 0 & o & 0 & o & 0 & 0 & 0 & 0 & N/A & N/A \\
\hline Chicago Ops (CH) TOTAL. & 18,691 & 14,928 & 3,763 & 20,339 & 19,244 & 1,095 & 21,930 & 13,645 & 8,285 & 13,519 & 11,852 & 8,001 & 2,243 \\
\hline Corrective Activities & 0 & 0 & 0 & 0 & 0 & 0 & 0 & 0 & o & $\mathbf{0}$ & 425 & 0 & 359 \\
\hline Waste Management & 7,840 & 5,291 & 2,549 & 2,492 & 2,364 & 128 & 2,246 & 1,960 & 286 & 1,559 & 4,285 & 711 & 132 \\
\hline Environmental Restoration & 5,837 & 4,623 & 1,214 & 8,271 & 7,304 & 967 & 10,159 & 2,160 & 7,999 & 5,081 & 2,183 & 4,756 & 1.427 \\
\hline Uranium Enrichment D\&D & 0 & 0 & 0 & 0 & 0 & 0 & 0 & 0 & 0 & 0 & 0 & N/A & N/A \\
\hline Technology Development & 0 & 0 & 0 & 9.566 & 9,566 & 0 & 9,125 & 9,125 & 0 & 5,744 & 3,949 & 2,534 & 325 \\
\hline Transportation Management & 0 & 0 & 0 & 10 & 10 & 0 & 400 & 400 & 0 & 1,135 & 1,010 & 0 & 0 \\
\hline Nuclear Material \& Fac. Stab. & 192 & 192 & 0 & 0 & 0 & 0 & 0 & 0 & 0 & 0 & 0 & N/A & N/A \\
\hline Compliance \& Program Coord. & 4,822 & 4,822 & 0 & $\mathbf{0}$ & 0 & 0 & 0 & 0 & 0 & N/A & N/A & N/A & N/A \\
\hline
\end{tabular}

Funding 5. Environmental Management Funding by State, Site, and Program in Descending Order by State Budget Request Totals. (Continued) 


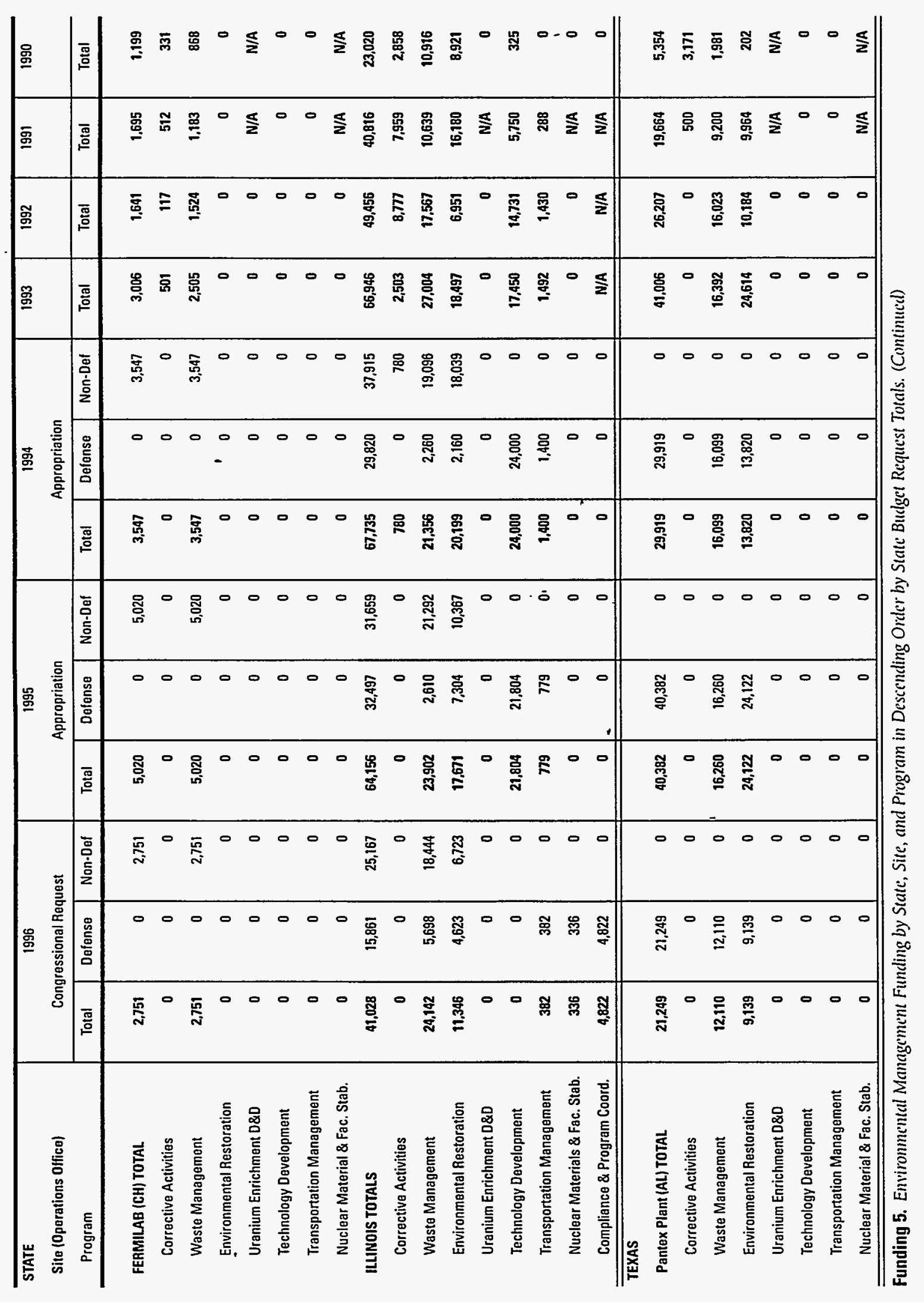




\begin{tabular}{|c|c|c|c|c|c|c|c|c|c|c|c|c|c|}
\hline \multirow{2}{*}{$\begin{array}{l}\text { STATE } \\
\text { Site (Operations Office) } \\
\text { Program } \\
\end{array}$} & \multicolumn{3}{|c|}{$\begin{array}{c}1996 \\
\text { Congressional Request }\end{array}$} & \multicolumn{3}{|c|}{$\begin{array}{c}1995 \\
\text { Appropriation }\end{array}$} & \multicolumn{3}{|c|}{$\begin{array}{c}1994 \\
\text { Appropriation }\end{array}$} & \multirow{2}{*}{$\begin{array}{l}1993 \\
\text { Total }\end{array}$} & \multirow{2}{*}{$\begin{array}{l}1992 \\
\text { Total } \\
\end{array}$} & \multirow{2}{*}{$\begin{array}{l}1991 \\
\text { Total }\end{array}$} & \multirow{2}{*}{$\begin{array}{l}1990 \\
\text { Total } \\
\end{array}$} \\
\hline & Total & Defense & Non-Def & Total & Defense & Non-Def & Total & Defense & Non-Def & & & & \\
\hline \multicolumn{14}{|l|}{ NEW JERSEY } \\
\hline Princeton Plasma (CH) TOTAL & 5,064 & 0 & 5,064 & 7,918 & o & 7,918 & 6,391 & 0 & 6,391 & 3,204 & 2.011 & 615 & 721 \\
\hline Corrective Activities & 0 & 0 & 0 & 0 & 0 & 0 & & 0 & D & 0 & 422 & 0 & 0 \\
\hline Waste Management & 5,064 & 0 & 5,064 & 7,918 & 0 & 7,918 & 6,391 & 0 & 6,391 & 3,204 & 1,589 & 615 & 721 \\
\hline Environmental Restoration & 0 & 0 & 0 & 0 & 0 & 0 & 0 & 0 & 0 & 0 & 0 & 0 & 0 \\
\hline Uranium Enrichment O\&D & 0 & 0 & 0 & o & D & 0 & 0 & 0 & 0 & o & 0 & N/A & N/A \\
\hline Technology Development & 0 & 0 & 0 & 0 & 0 & 0 & 0 & 0 & 0 & 0 & 0 & 0 & 0 \\
\hline Transportation Management & 0 & 0 & 0 & 0 & 0 & 0 & 0 & 0 & 0 & 0 & 0 & 0 & 0 \\
\hline Nuclear Material \& Fac. Stab. & 0 & 0 & 0 & 0 & 0 & 0 & 0 & 0 & 0 & 0 & 0 & N/A & N/A \\
\hline \multicolumn{14}{|l|}{ IOWA } \\
\hline Ames Lab (CH) TOTAL & 726 & 341 & 385 & 5,069 & 4,399 & 670 & 8,943 & 7,245 & 1,698 & 5,708 & 5,666 & 2,944 & 782 \\
\hline Corrective Activities & 0 & 0 & 0 & 0 & 0 & 0 & 0 & 0 & 0 & 0 & 0 & 0 & 0 \\
\hline Waste Management & 385 & 0 & 385 & 670 & 0 & 670 & 618 & 0 & 618 & 410 & 205 & 86 & $n$ \\
\hline Environmental Restoration & 341 & 341 & 0 & 300 & 300 & 0 & 3,305 & 2,225 & 1,080 & 666 & 817 & 230 & 0 \\
\hline Uranium Enrichment D\&D & 0 & 0 & 0 & 0 & 0 & 0 & 0 & 0 & 0 & 0 & 0 & N/A & N/A \\
\hline Technology Development & 0 & 0 & 0 & 4,099 & 4,099 & 0 & $5,020^{\circ}$ & 5,020 & 0 & 4,632 & 4,644 & 2,628 & 705 \\
\hline Transportation Management & 0 & 0 & 0 & 0 & 0 & 0 & 0 & 0 & 0 & $\mathbf{0}$ & 0 & o & 0 \\
\hline Nuclear Material \& Fac. Stab. & 0 & 0 & 0 & 0 & 0 & 0 & 0 & 0 & 0 & 0 & 0 & N/A & $N / A$ \\
\hline HEADQUARTERS TOTAL & $1,096,374$ & $1,083,860$ & 12,514 & 618,086 & 589,489 & 28,597 & 619,482 & 599,202 & 20,280 & 447.198 & 416,460 & 196,280 & 60,509 \\
\hline Corrective Activities & 0 & 0 & 0 & 0 & o & 0 & 0 & 0 & 0 & 0 & 7,323 & 0 & 0 \\
\hline Waste Management & 72,503 & 72,503 & 0 & 114,838 & 104,524 & 10,314 & 173,690 & 162,422 & 11,268 & 141,427 & 188,499 & 74,458 & 23,078 \\
\hline Environmental Restoration & 414,268 & 401,754 & 12,514 & 218,805 & 200,522 & 18,283 & 242,311 & 233,299 & 9,012 & 177,755 & 93,561 & 69,467 & 10,359 \\
\hline Uranium Enrichment D\&D & 0 & 0 & 0 & 0 & 0 & 0 & 0 & 0 & 0 & 0 & 0 & N/A & N/A \\
\hline Technology Development & 390,510 & 390,510 & 0 & 181,475 & 181,475 & 0 & 96,870 & 96,870 & 0 & 73,218 & 99,525 & 17,963 & 11,795 \\
\hline Transportation Management & 3,098 & 3,098 & 0 & 5,121 & 5,121 & 0 & 45 & 45 & 0 & 793 & 2,803 & 2,086 & 1,437 \\
\hline Nuclear Material \& Fac. Stab. & 19,674 & 19,674 & 0 & 12,899 & 12,899 & 0 & 14,670 & 14,670 & 0 & 3,205 & 0 & N/A & N/A \\
\hline Compliance \& Program Coord. & 39,299 & 39,299 & 0 & 0 & 0 & 0 & 0 & o & 0 & $N / A$ & N/A & N/A & N/A \\
\hline Analysis, Education \& Risk Mgmt. & 157,022 & 157,022 & 0 & 84,948 & 84,948 & 0 & 91,896 & 91,896 & 0 & 50,800 & 24,749 & 32,306 & 13,840 \\
\hline
\end{tabular}

Funding 5. Environmental Management Funding by Statc, Sitc, and Program in Descending Order by State Budget Request Totals. (Continued) 


\begin{tabular}{|c|c|c|c|c|c|c|c|c|c|c|c|c|c|}
\hline \multirow{2}{*}{$\begin{array}{l}\text { STATE } \\
\text { Site (Operations Office) } \\
\text { Program }\end{array}$} & \multicolumn{3}{|c|}{$\begin{array}{c}1996 \\
\text { Congressional Request } \\
\end{array}$} & \multicolumn{3}{|c|}{$\begin{array}{c}1995 \\
\text { Appropriation }\end{array}$} & \multicolumn{3}{|c|}{$\begin{array}{c}1994 \\
\text { Appropriation }\end{array}$} & \multirow{2}{*}{$\begin{array}{l}1993 \\
\text { Total }\end{array}$} & \multirow{2}{*}{$\begin{array}{l}1992 \\
\text { Total }\end{array}$} & \multirow{2}{*}{$\begin{array}{c}199 t \\
\text { Total }\end{array}$} & \multirow{2}{*}{$\begin{array}{l}1990 \\
\text { Total }\end{array}$} \\
\hline & Total & Defense & Non-Def & Total & Dofense & Non-Def & Total & Defense & Non-Def & & & & \\
\hline EM SUBTOTAL & $7,323,741$ & $6,321,944$ & $1,001,797$ & $6,374,967$ & $5,341,991$ & $1,032,976$ & $6,320,125$ & $5,340,853$ & 979,272 & $5,703,587$ & $4,312,061$ & $3,633,059$ & $2,274,136$ \\
\hline Corrective Activities & 8,810 & 3,406 & 5,404 & 27,212 & 512 & 26,700 & 26,418 & 7,202 & 19,216 & 61,317 & 120,574 & 187,960 & 104,793 \\
\hline Waste Management & $2,707.741$ & $2,501,596$ & 206,145 & $2,916,063$ & $2,673,047$ & 243,016 & $3,003,006$ & $2,763,624$ & 239,382 & $3,339,441$ & $2,464,437$ & $2,059,220$ & $1,393,923$ \\
\hline Environmental Restoration & $1,993,731$ & $1,575,973$ & 417,758 & $1,768,521$ & $1,379,924$ & 388,597 & $1,819,604$ & $1,454,447$ & 365,157 & $1,852,268$ & 1,379,989 & $1,102,422$ & 565,959 \\
\hline Uranium Enrichment D\&D & 288,807 & 0 & 288,807 & 301,327 & 0 & 301,327 & 286,320 & 0 & 286,320 & o & 0 & $N / A$ & \\
\hline Technology Development & 390,510 & 390,510 & 0 & 417,359 & 417,359 & 0 & 393,797 & 393,797 & 0 & 362,200 & 303,442 & 235,960 & 183,481 \\
\hline Transportation Management & 16,158 & 16,158 & 0 & 20,684 & 20,684 & 0 & 19,543 & 19,543 & 0 & 19,700 & 18,870 & 15,191 & 12,140 \\
\hline Nuclear Material \& Fac. Stab. & $1,679,711$ & $1,596,028$ & 83,683 & 838,853 & 765,517 & 73,336 & 679,541 & 610,344 & 69,197 & 17,861 & 0 & N/A & \\
\hline Compliance \& Program Coord. & 81,251 & 81,251 & 0 & 0 & 0 & 0 & 0 & 0 & 0 & N/A & N/A & N/A & \\
\hline $\begin{array}{l}\text { Analysis, Education, \& Risk } \\
\text { Mgmt. }\end{array}$ & 157,022 & 157,022 & 0 & 84,948 & 84,948 & 0 & 91,896 & 91,896 & 0 & 50,800 & 24,749 & 32,306 & 13,840 \\
\hline Use of Prior Balances & $(300,000)$ & $(276,942)$ & $(23,058)$ & $(257.481)$ & $(249,300)$ & $(8,181)$ & $(190,308\}$ & $(170,788)$ & $(19,520)$ & $(183,260)$ & $(25,162)$ & $(32,380)$ & \\
\hline Govt Contrib to D\&D Fund & $(350,000)$ & 0 & $(350,000)$ & $(133,700)$ & 0 & $(133,700)$ & $(129,805)$ & 0 & (129,805) & 0 & 0 & $\mathbf{0}$ & \\
\hline D\&D Fund Foreign Fees & $(45,000)$ & 0 & $(45,000)$ & 0 & & & 0 & & & 0 & 0 & 0 & \\
\hline Savannah River Pension Fund & $(37,000)$ & $(37,000)$ & 0 & N/A & & & N/A & & & N/A & N/A & N/A & \\
\hline EM TOTAL & $6,591,741$ & $6,008,002$ & 583,739 & $5,983,786$ & $5,092,691$ & 891,095 & $6,000,012$ & $5,170,065$ & 829,947 & $5,520,327$ & $4,286,899$ & $3,600,679$ & \\
\hline
\end{tabular}

Funding 5. Environmental Management Funding by State, Site, and Program in Descending Order by State Budget Request Totals. (Continued)

* "Analysis, Education, \& Risk Management" was formerly entitled "Program Direction" prior to the FY1996 Congressional budget request.

$\wedge$ The Formerly Utilized Sites Remedial Action Project represents 44 sites in 14 States.

$\wedge \wedge$ The Uranium Mill Tailings Remedial Action Project represents Environmental Restoration activities at 24 sites and approximately 5,000 vicinity properties in ten States.

The Uranium Enrichment Decontamination and Decommissioning Fund and the Nuclear Material and Facilities Stabilization (formerly called Facility Transition and Management) were not initiated until FY 1992. 


\section{Milestone Reports}

The following section provides an overview of Environmental Management's progress in completing its enforceable agreement milestones in 1994. Also included is a comparison of Environmental Management's performance in 1994 versus 1993.

Environmental Management currently has 71 active agreements in place that address cleanup and environmental compliance activities. The program made significant progress in meeting its enforceable agreement milestones in 1994. In 1993, the program completed 73 percent of its enforceable agreement milestones. In 1994, Environmental Management completed 87 percent, or 399. This includes completing 19 milestones for 1995 . This 19 percent improvement is due to a number of factors, including renegotiation of enforceable agreements and improved efficiency and effectiveness. A comparison of milestones completed in 1994 versus 1993 can be found in Milestone Reporr 3.

Every program improved its performance in meeting enforceable agreement milestones in 1994. Of the six sites with the largest number of enforceable milestones, Fernald had the most milestones (three) overdue by more than six months. Hanford, the Idaho National Engineering Laboratory, and Oak Ridge have no milestones overdue by more than six months. However, it is important to remember that Hanford's Tri-Party Agreement was renegotiated in 1994, and a Federal Facility Agreement and Consent Order was recently signed for the Idaho site.

\section{Milestone 1: Enforceable Agreement Milestone·Status}

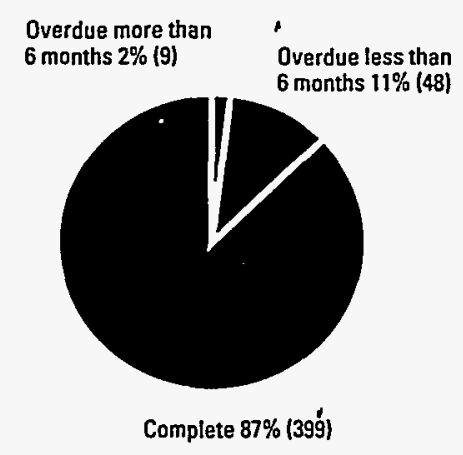

Milestone 1. Enforceable Agreement Milestone Status

\section{Milestone 2: Explanations for Missed Milestones More Than 6 Months Overdue}

At the end of 1994, only 9 of the 456 enforceable agreement milestones, or 2 percent, were more than 6 months overdue. All of these milestones were under the Environmental Restoration program's jurisdiction, which is responsible for 69 percent of all Environmental Management milestones.

Two of the milestones were late due to regulatory or approval delays, one due to unexpected or uncontrollable delays, three due to changes in the scope or mission of the site, one due to renegotiations of enforceable agreements, one because priorities at the site have shifted, and one was delayed because a preceding milestone was late.

The following table describes which sites are responsible for the milestones, what actions the milestones are tracking, and explanations for the delays. Please note that the overdue milestones at the Fernald site are program execurion milestones, not enforceable agreement milestones. Because these milestones are tracked in the Progress Tracking System, they are listed here. 


\begin{tabular}{|c|c|c|c|}
\hline Site & Milestone & Months Late & Explanation for Delay \\
\hline \multirow[t]{2}{*}{$\begin{array}{l}\text { Fernald Environmental } \\
\text { Management Project }\end{array}$} & $\begin{array}{l}\text { Submit Subcontractor's } \\
\text { Removal Action Project Plan } \\
\text { for Scrap Metals Piles to } \\
\text { Environmental Protection } \\
\text { Agency }\end{array}$ & 11 & $\begin{array}{l}\text { Scrap copper activities were } \\
\text { delayed because subcontract } \\
\text { award date was delayed by } \\
\text { Environmental Legal Affairs } \\
\text { concerns and characterization } \\
\text { of the scrap copper. This } \\
\text { removal action is on hold; the } \\
\text { project is being replanned for } \\
1996 \text {. }\end{array}$ \\
\hline & $\begin{array}{l}\text { Submit Final Subcontractor's } \\
\text { Removal Action Project Plan } \\
\text { for Scrap Metal Piles to } \\
\text { Environmental Protection } \\
\text { Agency }\end{array}$ & 9 & $\begin{array}{l}\text { Delayed because preceding } \\
\text { milestone is delayed. }\end{array}$ \\
\hline $\begin{array}{l}\text { Fernald Environmental } \\
\text { Management Project }\end{array}$ & $\begin{array}{l}\text { Initiate Part } 1 \text { "EE/CA" } \\
\text { Revision }\end{array}$ & 6 & $\begin{array}{l}\text { Received verbal concurrence } \\
\text { from U.S. Environmental } \\
\text { Protection Agency to } \\
\text { eliminate this action. This } \\
\text { milestone will be deleted from } \\
\text { the Progress Tracking System } \\
\text { when CP is approved. }\end{array}$ \\
\hline \multirow[t]{2}{*}{$\begin{array}{l}\text { Rocky Flats Environmental } \\
\text { Technology Site }\end{array}$} & $\begin{array}{l}\text { Submit Draft CMS/ } \\
\text { Feasibility Study Report for } \\
903 \text { Pad, Mound, and East } \\
\text { Trenches }\end{array}$ & 10 & $\begin{array}{l}\text { An extension request is } \\
\text { pending. }\end{array}$ \\
\hline & $\begin{array}{l}\text { Submit Draft Phase I RFI/RI } \\
\text { Report }\end{array}$ & 6 & $\begin{array}{l}\text { There is a proposed deferral of } \\
\text { work for the Industrial Area in } \\
\text { conjunction with Transition } \\
\text { and Decontamination } \\
\text { schedules. The State and } \\
\text { Environmental Protection } \\
\text { Agency denied a request for } \\
\text { extension to } 1 / 12 / 95 \text { on } 2 / 15 / \\
94 \text {. Stipulated penalties are in } \\
\text { effect and dispute resolution } \\
\text { process was invoked on } 3 / 1 / \\
94 . \text { Expected completion date } \\
\text { is August } 30,2002 \text {, based on } \\
\text { current schedule. }\end{array}$ \\
\hline
\end{tabular}

Milestone 2. Sites responsible for milestones - actions the milestones are tracking - and explanations for the delays. 


\begin{tabular}{|c|c|c|c|}
\hline Site & Milestone & Months Late & Explanation for Delay \\
\hline Savannah River Site & $\begin{array}{l}\text { Submit Records of Decision } \\
\text { for } 200 \text { Area Ground Water to } \\
\text { Environmental Protection } \\
\text { Agency }\end{array}$ & 8 & $\begin{array}{l}\text { The process for obtaining and } \\
\text { resolving comments on the } \\
\text { Proposed plans has been an } \\
\text { on-going issue since late } 1993 \text {. } \\
\text { Several attempts to anticipate } \\
\text { resolution have failed, causing } \\
\text { a continual slip in the } \\
\text { milestone date. A schedule } \\
\text { has been developed, and } \\
\text { concurred on by the } \\
\text { regulators, which sets the } \\
\text { revised date at } 8 / 15 / 95 \text {. }\end{array}$ \\
\hline $\begin{array}{l}\text { Inhalation Toxicology } \\
\text { Research Institute }\end{array}$ & $\begin{array}{l}\text { Complete Ground Water } \\
\text { Remedial Action Plan }\end{array}$ & 6 & $\begin{array}{l}\text { Development of this plan is } \\
\text { dependent on future ground- } \\
\text { water quality analyses. } \\
\text { Monitoring well installation, } \\
\text { as State requested, is compete. } \\
\text { This milestone cannot be } \\
\text { resolved until sludge from } \\
\text { Sanitary Lagoon is contained. }\end{array}$ \\
\hline $\begin{array}{l}\text { Sandia National Laboratory- } \\
\text { Livermore }\end{array}$ & $\begin{array}{l}\text { Complete Radioactive Waste } \\
\text { Quality Control Board SWAT } \\
\text { Approval on the Navy Landfill }\end{array}$ & 23 & $\begin{array}{l}\text { The Board has not completed } \\
\text { its review of the Navy Landfill } \\
\text { SWAT report. The Board } \\
\text { requires additional monitoring } \\
\text { wells to address concerns } \\
\text { about the ground-water flow } \\
\text { at the Navy Landfill area. } \\
\text { Review now expected by end } \\
\text { of September } 1994 \text {. }\end{array}$ \\
\hline
\end{tabular}

Milestone 2. Sites responsible for milestones-actions the milestones are tracking-and explanations for the delays. (Continued) 


\section{Milestone 3: Comparison of Environmental Management Performance in Meeting Milestones in 1994}

vs. 1993.

The Environmental Restoration program is responsible for 69 percent, or 305, of all Environmental Management milestones. All but two of the overdue milestones are Environmental Restoration milestones. Waste Management, which was responsible for 129 enforceable agreement milestones in 1994, completed 99 percent, or 127. Facility Transition and Management completed all three of its 1994 enforceable agreement milestones. Technology Development did not have any enforceable agreement milestones in 1994.

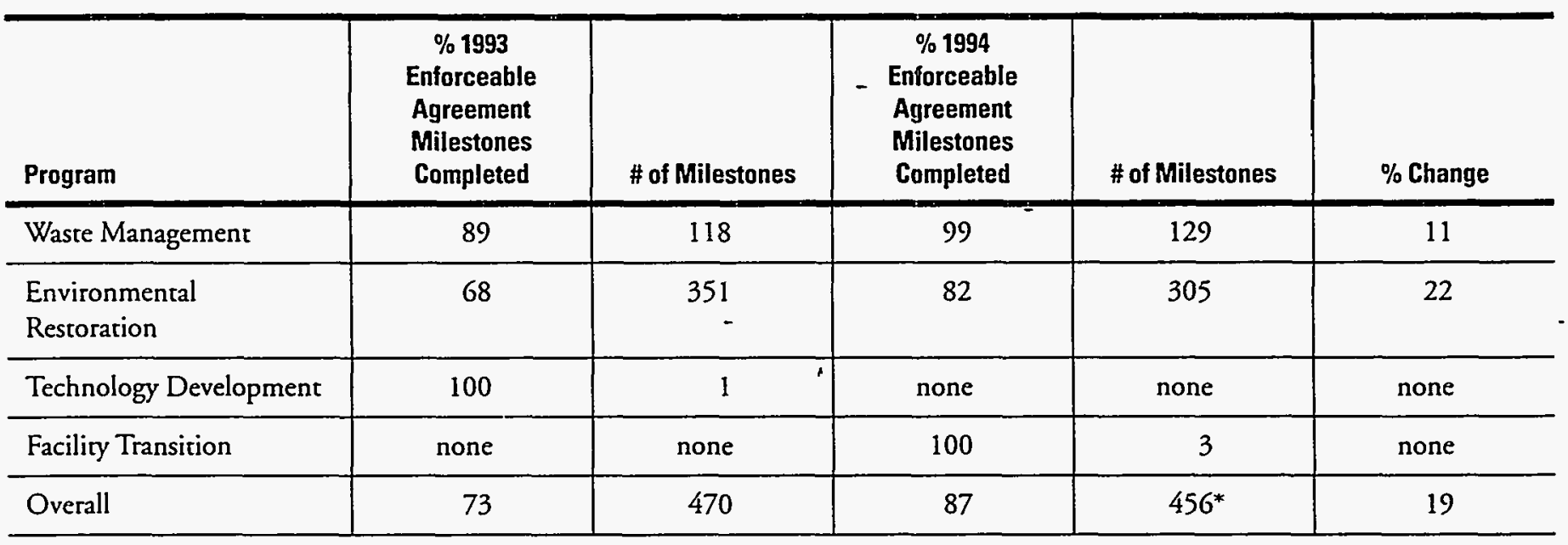

Milestone 3. Comparison of Environmental Management Performance in Meeting Milestones in 1994 vs. 1993.

*Represents 437 enforceable agreement milestones due in 1994, plus the 19 milestones due in 1995 which were completed early by Waste Management and Facility Transition and Management.

\section{Performance Reports}

This section will describe Environmental Management's progress by assessing cost and schedule variances. These two indicators allow Environmental Management to determine 1) how spending compares to the estimated costs.and 2) the estimated value of the work compared to what the work actually cost. These charts measure the amount of work completed compared to the amount of work planned (schedule). They also measure the cost of that work compared to the planned cost. All of this information is tracked in the Environmental Management Progress Tracking System. Cost and Schedule summary charts, depicting the performance of all sites that report independently, are provided in this section of the report.

The National Defense Authorization Act for Fiscal Year 1994 requires that Environmental Management report all sites having a cost variance of 15 percent greater or $\$ 10$ million or larger and those sires with a schedule variance of 6 .months or more. In 1994,10 sites exhibited cost variances more than 15 percent or $\$ 10$ million or greater, and 17 sites have a rotal schedule variance of $\$ 10$ million or 15 percent. More detail about these variances can be found in Report 2 of this section.

The Environmental Restoration program showed the greatest improvement by spending 8 percent less than planned in 1994, compared to 19 percent in 1993. This program completed 92 percent of the originally scheduled work and that work cost 99 percent of what it was originally planned to cost. Facilities Stabilization overspent its plan by 12 percent in 1994 . This is mostly a result of a procedural accounting error, which the Department Controller Office is working to correct.

In 1994, Environmental Management was chosen to be a pilot project for the Government Performance and Results Act. This involves developing Stracegic Plans, Annual Performance Plans, and Annual Performance Reports to demonstrate how inputs, ourputs, and outcomes are linked, and to improve planning, budgeting, and performance results. Progress on the performance measures in the Environmental Management 1994 Performance Plan, dated May 31, 1994, is addressed in Report 4 of this section. 


\section{Performance 1: Cost and Schedule Performance of Environmental Management Sites in 1994.}

The following table is a summary of the cost and schedule performance for all Environmental Management sites in 1994. The following definitions will help the reader understand how the program evaluates cost and schedule performance.

Planned cost is the amount of money that a site estimates will be required to perform the scheduled activities for a given period, usually a year.

Schedule variance is measured.by determining the accomplished cost of work. This is a calculation of the dollar value of work completed. The accomplished cost minus the planned cost yields the schedule variance. A positive number means that, compared to the original estimate, the work performed was ahead of schedule. A negarive number indicates that work performed was behind schedule.

Cost variance is measured by determining the actual cost of work performed. This is the total amount of dollars spent and costs incurred by the program for work performed. Actual cost subtracted from accomplished cost yields the cost variance. A positive number indicates that the Department paid less than the value of the work performed (more efficient or under cost for work performed). A negative number indicates that the program paid more than the value of the work performed (less efficient or over cost for work performed).

The majority of the 45 sites listed in the following table were either over cost ( 14 sites) or were behind schedule ( 31 sires), or in some cases both (10 sites). Five sites reported no cost variance and five sites reported no schedule variance in 1994. This is a significant improvement from last year, when 19 sites were less efficient, 27 sites were behind schedule, and 14 were borh.

The 9 sites with the largest planned cost represents 81 percent of the total Environmental Management expenditures. Therefore, their performance impacts the program significantly. Overall, these sites were behind schedule and over cost in 1994. The Hanford Site, which has the largest planned cost, was 8 percent behind schedule and 3 percent over cost for the work performed. Savannah River, which has the second largest planned cost, was 6 percent behind schedule, but was 4 percent under cost. It is important to remember that this is a summary of all activities at these sites and in many cases, significant cost savings and accelerated schedules are aggregared by projects that are delayed but cost more. For more detail, please see the more detailed breakdown of performance by program in Report 3 of this section.

This data is presented by magnitude of planned costs, in descending order. Nor all sites described in the previous section are listed in this table. Many of the smaller sites report through Operations Offices. The FUSRAP and UMTRA figures reflect totals for the 46 FUSRAP and 24 UMTRA sites nationwide. This data is taken from the Environmental Management Progress Tracking System.

\begin{tabular}{l|c|c|c|c}
\hline Site Name & State & $\begin{array}{c}\text { Planned Cost in } \\
\text { Millions S }\end{array}$ & Cost Variance\% & Schedule Variance\% \\
\hline Hanford Site & WA & 1,752 & -3 & -8 \\
\hline Savannah River Site & SC & 839 & 4 & -6 \\
\hline Oak Ridge Reservation & TN & 697 & -3 & -3 \\
\hline $\begin{array}{l}\text { Rocky Flats Environmental } \\
\text { Technology Site }\end{array}$ & CO & 655 & 5 & -11 \\
\hline $\begin{array}{l}\text { Idaho National Engineering } \\
\text { Laboratory }\end{array}$ & ID & 637 & -1 & -9 \\
\hline Headquarters & DC & 415 & -32 & -9 \\
\hline $\begin{array}{l}\text { Fernald Environmental Management } \\
\text { Project }\end{array}$ & OH & 375 & 8 & -11 \\
\hline Los Alamos National Laboratory & NM & 251 & -2 & -15 \\
\hline Waste Isolation Pilor Plant & NM & 157 & 0 & 0 \\
\hline
\end{tabular}

Performance 1. 1994 Cost and Schedule Performance for Environmental Management Sites 


\begin{tabular}{|c|c|c|c|c|}
\hline Site Name & State & $\begin{array}{l}\text { Planned Cost in } \\
\text { Millions \$ }\end{array}$ & Cost Variance\% & Schedule Variance $\%$ \\
\hline West Valley Demonstration Project & NY & 129 & 0 & -4 \\
\hline $\begin{array}{l}\text { Sandia National Laboratory- } \\
\text { Albuquerque }\end{array}$ & NM & 104 & 12 & -3 \\
\hline UMTRA Project & NM & 101 & 11 & 8 \\
\hline Nevada Test Site & NV & 92 & 3 & -14 \\
\hline Albuquerque Operations Office & NM & 91 & -2 & -5 \\
\hline Portsmouth Gaseous Diffusion Plant & $\mathrm{OH}$ & 81 & -32 & -17 \\
\hline $\begin{array}{l}\text { Lawrence Livermore National } \\
\text { Laboratory }\end{array}$ & $\mathrm{CA}$ & 80 & 1 & 3 \\
\hline Argonne National Laboratory-East & IL & 80 & 1 & -1 \\
\hline Mound Plant & $\mathrm{OH}$ & 60 & 14 & 7 \\
\hline Paducah Gaseous Diffusion Plant & KY & 53 & -19 & -17 \\
\hline Weldon Spring Site & MO & 48 & -49 & -15 \\
\hline FUSRAP & $\mathrm{TN}$ & 47 & 6 & -4 \\
\hline $\begin{array}{l}\text { Morgantown Environmental } \\
\text { Technology Center }\end{array}$ & WV & 45 & 2 & -16 \\
\hline Grand Junction Projects Office & $\mathrm{CO}$ & 44 & 2 & -7 \\
\hline Chicago Operations Office & IL & 39 & 4 & 10 \\
\hline Pantex Plant & $\mathrm{TX}$ & 38 & -7 & 10 \\
\hline Brookhaven National Laboratory & $N \underline{Y}$ & 36 & 6 & -8 \\
\hline Battelle Columbus Laboratories & $\mathrm{OH}$ & 26 & 6 & -3 \\
\hline Kansas City Plant & MO & 19 & 18 & 7 \\
\hline Lawrence Berkeley Laboratory & $\mathrm{CA}$ & 19 & -1 & -13 \\
\hline Pinellas Plant & FL & 12 & 33 & -16 \\
\hline Oakland Operations Office & $\mathrm{CA}$ & 11 & 28 & -10 \\
\hline Sandia National Laboratory-Livermore & CA & 11 & 16 & 8 \\
\hline Argonne National Laboratory - West & ID & 10 & 2 & -2 \\
\hline Ames Laboratory & IA & 9 & 9 & -2 \\
\hline University of California & $\mathrm{CA}$ & 8 & 18 & -25 \\
\hline
\end{tabular}

Performance 1. 199+ Cost and Schedule Performance for Environmental Management Sites (Continued) 
Performance and funding Data

\begin{tabular}{l|c|c|c|c}
\hline Site Name & State & $\begin{array}{c}\text { Planned Cost in } \\
\text { Millions S }\end{array}$ & Cost Variance\% & Schedule Variance\% \\
\hline Princeton Plasma Laboratory & NJ & 7 & 24 & 0 \\
\hline Santa Susana Field Laboratory & CA & 7 & -19 & 10 \\
\hline Stanford Linear Accelerator Center & CA & 5 & 0 & -24 \\
\hline General Atomics & CA & 5 & 3 & -10 \\
\hline $\begin{array}{l}\text { Inhalation Toxicology Research } \\
\text { Institute }\end{array}$ & NM & 4 & -29 & -41 \\
\hline Fermi National Accelerator Laboratory & IL & 3 & 16 & 0 \\
\hline $\begin{array}{l}\text { General Electric Vallecitos Nuclear } \\
\text { Center }\end{array}$ & CA & 0 & 0 & -97 \\
\hline
\end{tabular}

Performance 1. 1994 Cost and Schedulc Performance for Environmental Management Sites (Continued) 


\section{Performance 2: Explanations of Variances}

From the sites listed in Performance 1 , the sites listed below have total cost and schedule variances exceeding $\$ 10$ million or 15 percent. For the purposes of this report, Environmental Management evaluates the cumulative performance of the site, because each site may have hundreds of projects tracked in the Progress Tracking System. The performance of some projects is offset when the total site performance is measured. Information on a project by project basis is available by contacting the Environmental Management program.

\begin{tabular}{l|c|c|c|c|c}
\hline Site (in alphabetical order) & State & $\begin{array}{c}\text { Cost Variance } \\
\mathbf{S} \text { in Thousands }\end{array}$ & $\begin{array}{c}\text { Schedule } \\
\text { Cost }\end{array}$ & $\begin{array}{c}\text { Variance in } \\
\mathbf{S} \text { in } \\
\text { thousands }\end{array}$ & $\begin{array}{c}\text { Schedule } \\
\text { Variance\% }\end{array}$ \\
\hline Fernald Environmental Management Project & $\mathrm{OH}$ & 27,834 & 8 & $-41,078$ & -11 \\
\hline
\end{tabular}

Several delays in implementing safe shutdown activities account for most of the cost and schedule variance. Corrective actions were made and safe shutdown activities are on schedule.

\begin{tabular}{l|l|l|l|l|l}
\hline General Electric Vallecitos Nuclear Center & CA & 0 & 0 & -105 & -97 \\
\hline
\end{tabular}

Delays in getting a contract in place to perform environmental management work have delayed commencement of work.

\begin{tabular}{l|l|l|l|l|l|}
\hline Hanford Site & WA . & $-46,973$ & -3 & $-132,923$ & -8 \\
\hline
\end{tabular}

Schedule variance is mostly attributed to delays in acquiring materials, deploying core sampling capability, and getting subcontractors in place so remediation work could begin. Other variances are due to baselines not being previously developed for program direction and other managerial tasks, so these tasks were not entered in the Progress Tracking System. Baselines were developed for 1995 .

\begin{tabular}{l|l|l|l|l|l|}
\hline Headquarters & DC & $-120,809$ & -32 & $-35,694$ & -9 \\
\hline
\end{tabular}

Prior to the second quarter of 1994, plans for a majority of Headquarter's activities were not tracked by the Progress Tracking System, resulting in large cost variances. Since then, a concerted effort has been made to rectify this situation. In 1995, all funded tasks will be planned and tracked, providing a more realistic assessment of performance.

\begin{tabular}{|c|c|c|c|c|c|}
\hline Idaho National Engineering Laboratory & ID & $-4,269$ & -1 & $-58,255$ & -9 \\
\hline \multicolumn{6}{|c|}{$\begin{array}{l}\text { Variance largely due to unrealistic scheduling, delays in contracts, and privatization of Pit } 9 \text {. Funding issues regarding the Wast } \\
\text { Management Contract Retrieval facility and the Chemical Processing Plant resulted in the cost variance. }\end{array}$} \\
\hline Inhalation Toxicology Research Institute & NM & -619 & -29 & $-1,480$ & -41 \\
\hline
\end{tabular}

Variance in the Waste Management area is due to delays in procuring a contractor for various general plant projects. The variance in the Environmental Restoration area is due to an accounting error.

\begin{tabular}{l|c|c|c|c|c|c}
\hline Los Alamos National Laboratory & NM & $-4,181$ & -2 & $-38,079$ & -15 \\
\hline Explanation & NV & 2,646 & 3 & $-13,174$ & -14 \\
\hline Nevada Test Site
\end{tabular}

Schedule variances resulted from delays in construction projects, state permitting, and design activities. Construction projects are scheduled to be completed in 1995.

\begin{tabular}{l|l|l|l|l|l|}
\hline Oak Ridge Reservation & TN & $-17,979$ & -3 & $-23,178$ & -3 \\
\hline
\end{tabular}

Performance 2. Explanations of Variances 


\begin{tabular}{c|c|c|c|c|c}
\hline- & & Cost Variance & $\begin{array}{c}\text { Cost } \\
\text { Variance\% }\end{array}$ & $\begin{array}{c}\text { Variance in } \\
\text { Sin } \\
\text { thousands }\end{array}$ & $\begin{array}{c}\text { Schedule } \\
\text { Variance\% }\end{array}$ \\
\hline
\end{tabular}

Delays in incorporating project scope changes into the Progress Tracking System and bringing on a new Technical Support Contractor for the Department is the major reason for the small overall variance.

\begin{tabular}{l|l|l|l|l|l|}
\hline Paducah Gaseous Diffusion Plant & KY & $-8,385$ & -19 & $-9,260$ & -17 \\
\hline
\end{tabular}

Delays in incorporating the new scope for waste management and offsite ground water activities into the Progress Tracking System is the primary reason for the variance.

\begin{tabular}{l|l|l|l|l|l|}
\hline Pinellas Plant & FL & 3,391 & 33 & $-2,022$ & -16 \\
\hline
\end{tabular}

Variance is a result of lessened disposal costs for hazardous wastes, no PRP payment at Peak Oil sites, delays in regulatory approval of environmental documentation and state permitting design activities, and double utilization of ground water treatment systems

Portsmouth Gaseous Diffusion Plant

$\mathrm{OH}$

$-21,566$

$-32$

$-13,977$

$-17$

Variances are attributed to additional investigation work to determine the nature and extent of contamination, delays in regulatory approval resulting in delayed construction of some RCRA closures, and delays in incorporating the scope for waste management.

\begin{tabular}{l|l|l|l|l|l}
\hline Rocky Flats Environmental Technology Site & CO & 27,044 & 5 & $-70,438$ & -11 \\
\hline
\end{tabular}

Subcontractors billing the site later than expected and errors in actual costs reported in the Progress Tracking System contributed to the cost variances. The schedule variance is attributed to delayed fund transfer requests from local communities and delays in transporting and storing sludge from a Solar Pond due to technical problems and delayed approval by the Colorado Department of Public Health and Environment.

\begin{tabular}{l|l|l|l|l|l}
\hline Santa Susana Field Laboratory & CA & $-1,375$ & -19 & 700 & 10 \\
\hline
\end{tabular}

Variances can be attributed to delays in obtaining regulator approval of a corrective action and delays in shipment and payments to vendor for decontaminating lead and shipping it offsite.

\begin{tabular}{ll|l|l|l|l|l|}
\hline Savannah River Site & - & SC & 34,161 & 4 & $-48,485$ & -6 \\
\hline
\end{tabular}

Delays in construction; design delays due to resolution of concerns; reprogramming and rescheduling efforts; revised plans to achieve greater economic development in the local community causing schedule delays.

\begin{tabular}{l|c|c|c|c|c}
\hline Stanford Linear Accelerator Center & CA & -3 & 0 & $-1,230$ & -24 \\
\hline
\end{tabular}

Interim removal actions were delayed to achieve lower disposal costs and difficulties in procuring contractor support.

\begin{tabular}{|c|c|c|c|c|c|}
\hline University of California & $\mathrm{CA}$ & 1,040 & 18 & $-1,938$ & -25 \\
\hline \multicolumn{6}{|c|}{ Remedial Investigation studies exceeded anticipated costs. } \\
\hline Weldon Spring Site & MO & $-19,845$ & -49 & $-7,013$ & -15 \\
\hline
\end{tabular}

Performance 2. Explanations of Variances (Continued) 


\begin{tabular}{c|c|c|c|c|c}
\hline- & & Schedule & Cost Variance \\
Site (in alphabetical order) & State & $\begin{array}{c}\text { Cost } \\
\text { Sin Thousands }\end{array}$ & $\begin{array}{c}\text { Variance in } \\
\text { \$ in } \\
\text { thousands }\end{array}$ & $\begin{array}{c}\text { Schedule } \\
\text { Variance\% }\end{array}$ \\
\hline
\end{tabular}

Adjustment of the Department's and the Army's share of costs resulted in reallocation of some costs previously charged to the Army. In addition, previous years' costs related to an increased contractor's fee was recognized in 1994.Problems in schedule performance are attributed to emergency berm repairs due to flooding in 1993, additional work on the Chemical Stabilization/ Solidification pilot plant, and construction problems at the Site Water Treatment Plant.

Performance 2. Explanations of Variances (Continued)

\section{Performance 3: Site Cost and Schedule Performance by Program in 1994}

The Performance information in the two proceeding sections were categorized by site. The following four graphs are organized by program and site to demonstrate how the programs performed at major sites. The Environmental Restoration program showed the greatest improvement by spending 8 percent less than planned in 1994, compared to 19 percent in 1993. This program completed 92 percent of the originally scheduled work and that work cost 99 percent of what it was originally planned to cost. The Nuclear Material and Facilities Stabilization overspent its plan by 12 percent in 1994. This is mostly a result of a procedural accounting error, which the Department Controller Office is working to correct. The Technology Development program graph on the following page shows that the program was about 19 percent behind schedule in 1994, and technology development activities at the Savannah River Site were 60 percent behind schedule. About 4 percent of the total schedule variance is attributed to unexpected activities associated with the Savannah River Site Economic Development program, and 9 percent is due to plans for 1995 being incorporated into the 1994 planned work baseline. Excluding the Savannah River Site, technology development activities were only 6 percent behind schedule in 1994.

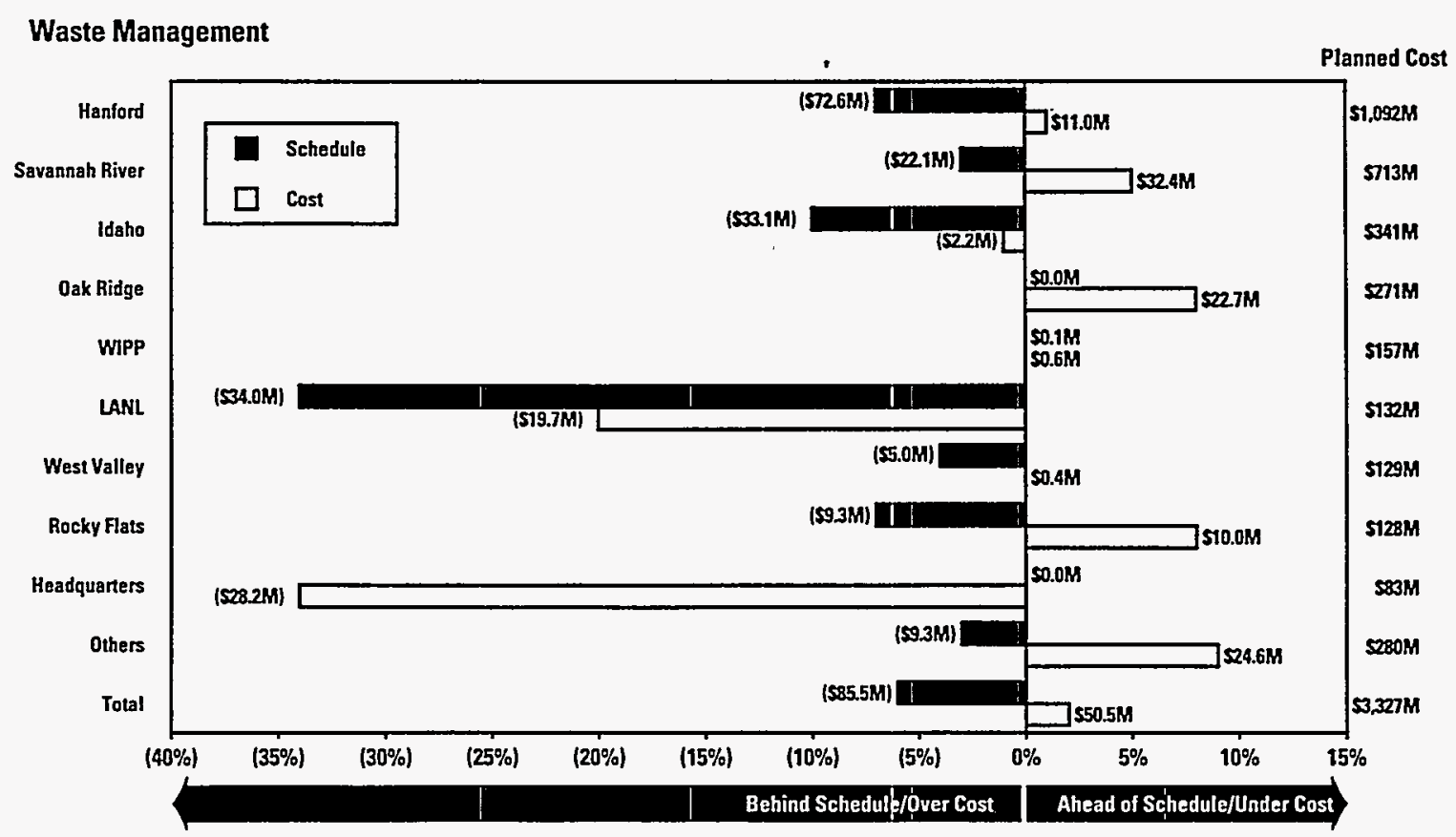

Performance 3. Sitc Cost and Schedule Performance by Program in 1994. 
Environmental Restoration

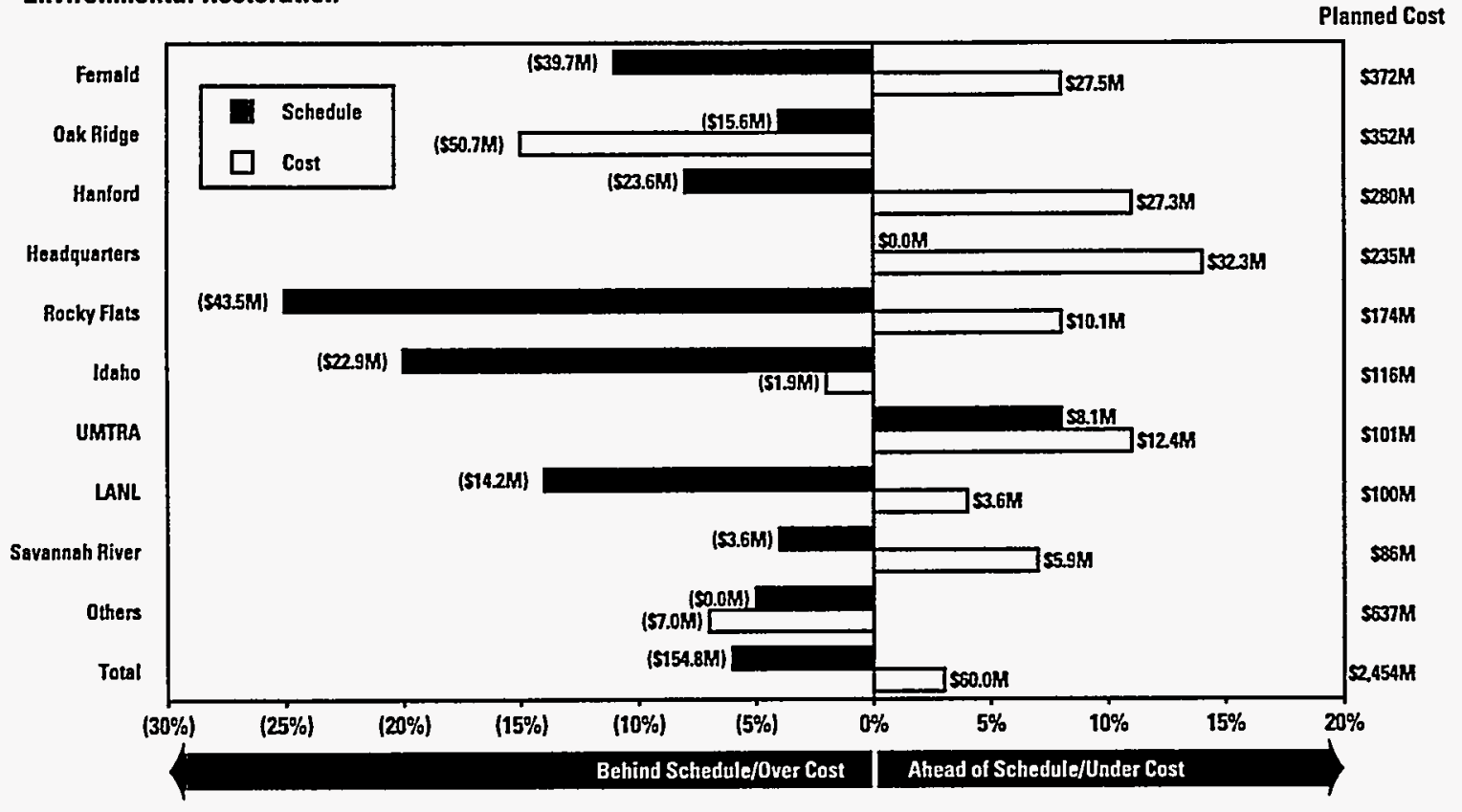

Technology Development

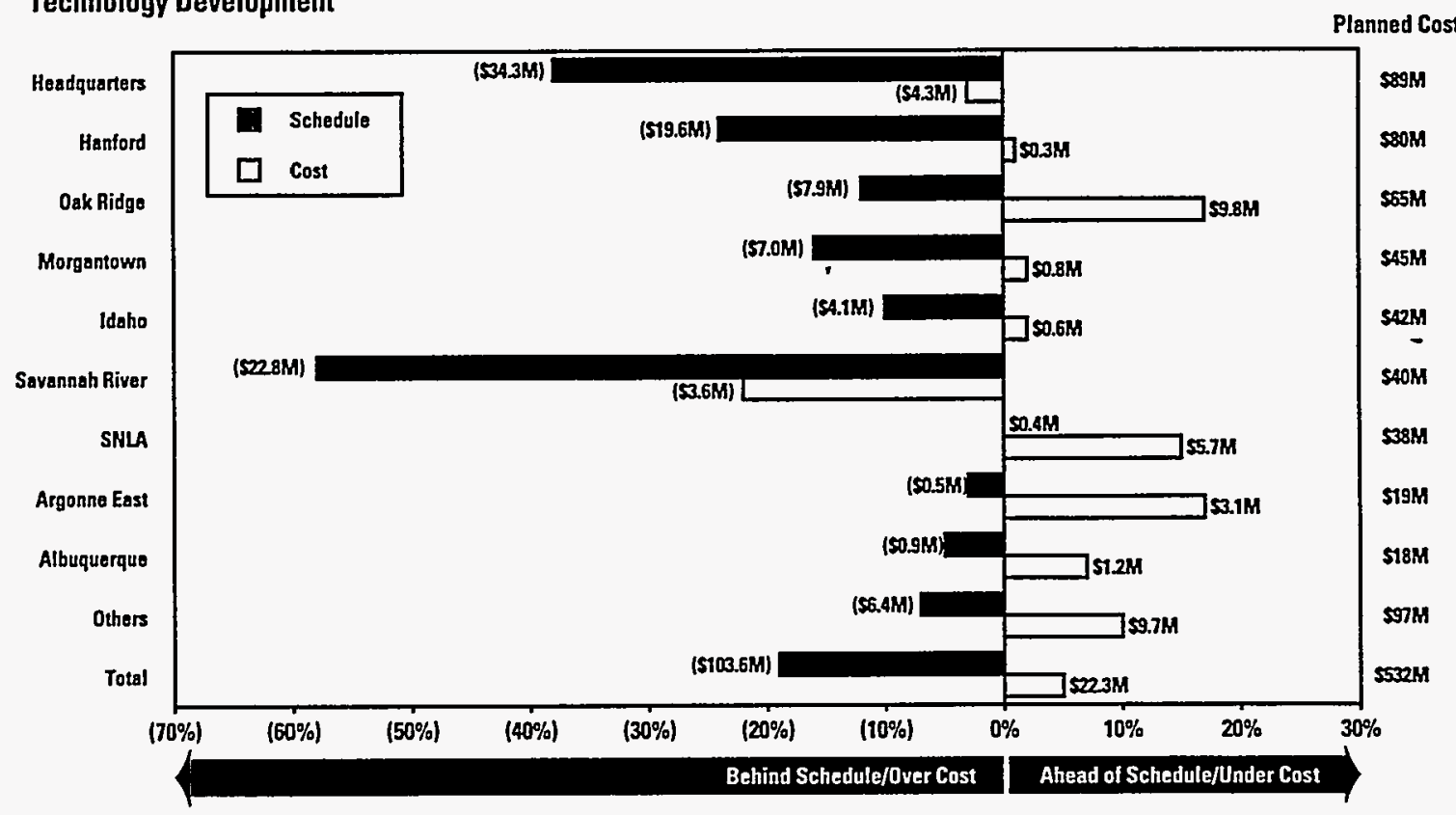

Performance 3. Site Cost and Schedule Performance by Program in 1994. (Continued) 


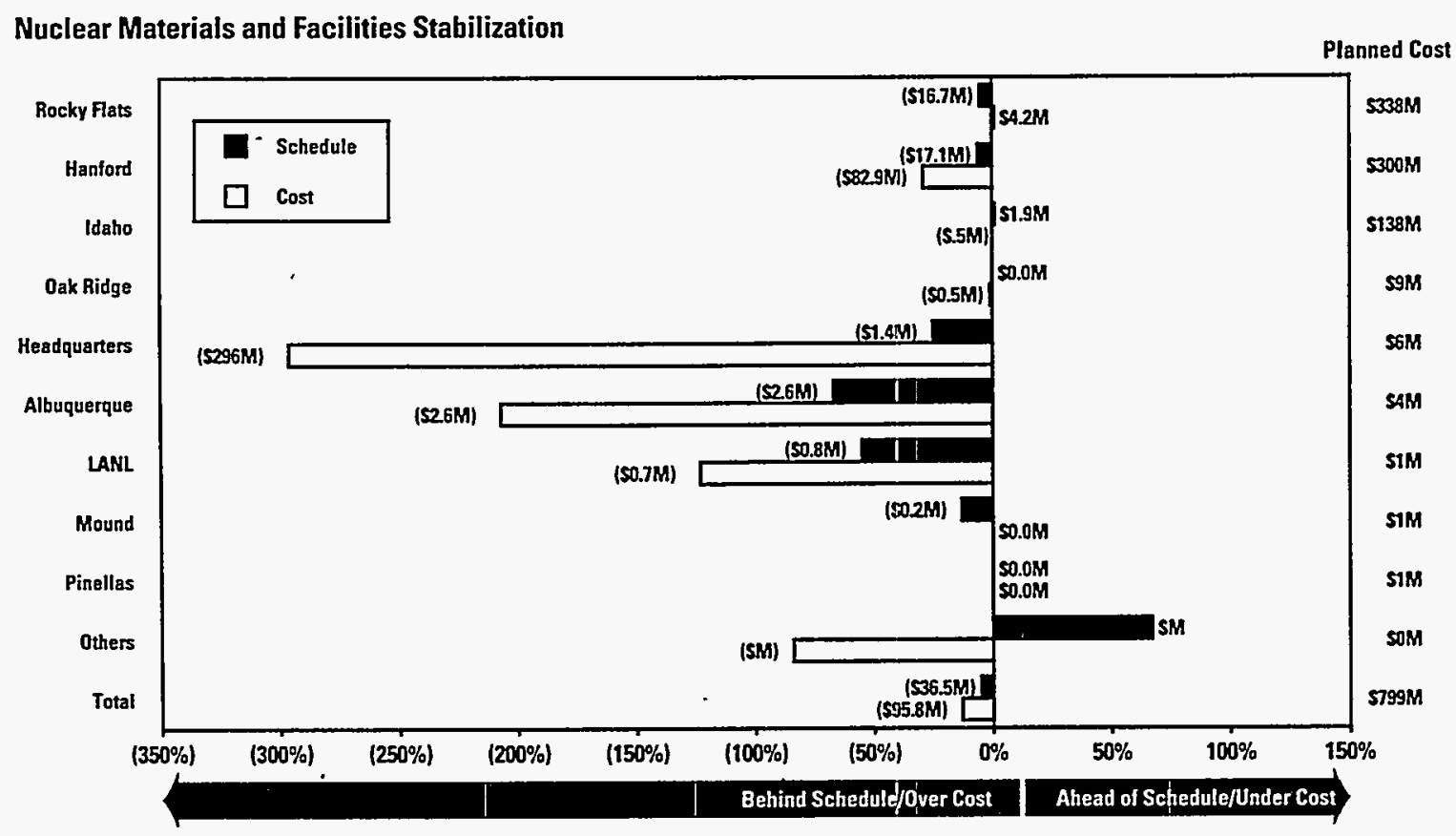

Performance 3. Site Cost and Schedule Performance by Program in 1994. (Continued) 


\section{Performance 4: Comparison of Cost and Schedule Performance in 1994 vs. 1993.}

In 1994, Environmental Management improved its ability to plan what the program will spend. This is reflected in a $\$ 477$ million reduction in uncosted balances, or appropriated funds which are not utilized. In addition, the program spent 5 percent less than planned in 1994, a significant improvement from 13 percent last year. In 1994, 93 percent of the originally scheduled work was completed at 102 percent of what it was originally planned to cost. A review of the program's first quarter performance reflected that over $\$ 240$ million of Headquarters tasks were not planned. Since then, a concerted effort has been made to rectify this. At the end of 1994, only $\$ 40$ million in tasks is unplanned. In 1995, all funded tasks will be planned in the Progress Tracking System, including program direction and operations tasks.

\begin{tabular}{l|c|c|c|c|c}
\hline \multirow{2}{*}{ Site } & \multirow{2}{*}{} & \multicolumn{2}{|c|}{1993} & \multicolumn{2}{c}{1994} \\
\cline { 3 - 6 } & State & $\begin{array}{c}\text { Cost } \\
\text { Variance\% }\end{array}$ & $\begin{array}{c}\text { Schedule } \\
\text { Variance\% }\end{array}$ & $\begin{array}{c}\text { Cost } \\
\text { Variance\% }\end{array}$ & $\begin{array}{c}\text { Schedule } \\
\text { Variance\% }\end{array}$ \\
\hline Hanford Site & WA & 0 & -10 & -8 & -3 \\
\hline Savannah River Site & SC & 9 & -4 & -6 & 4 \\
\hline Oak Ridge Reservation & TN & 25 & -9 & -3 & -3 \\
\hline Rocky Flats Environmental Technology Site & CO & 12 & -9 & -11 & 5 \\
\hline Idaho National Engineering Laboratory & ID & -1 & -9 & -9 & -1 \\
\hline Fernald Environmental Management Project & OH & -4 & -14 & -11 & 8 \\
\hline Waste Isolation Pilot Plant & NM & 10 & -15 & 0 & 0 \\
\hline Los Alamos National Laboratory & NM & -19 & -13 & -15 & -2 \\
\hline
\end{tabular}

Performance 4. Comparison of Cost, Schedule, Performance in 1994 vs. 1993.

\section{Performance 5: Results of the Performance Measurement Pilot Project}

Congress passed the Government Performance and Results Act in 1994 to improve planning, budgeting, performance, and results of government agencies. In the Spring of 1994, the Office of Management and Budget selected the Environmental Management program as a pilot project. Under this Act, Environmental Management is responsible for preparing Strategic Plans, Annual Performance Plans, and Annual Performance Reports to measure performance.

Environmental Management developed performance measures that were closely aligned to the six strategic goals established by Assistant Secretary Grumbly in 1993. Because this effort began in the middle of the year, the 1994 measures provided a rough indicator of areas where measurement is possible. The Environmental Management initial Performance Plan for 1994 was submitted to the Office of Management and Budget on May 31, 1994, and their preliminary assessment of this plan was generally favorable compared to those submitted by other programs. Their comments did indicate, however, that there remains considerable opportunity for improving these measures.

Environmental Management's assessment against its first annual performance plan is due to the Office of Management and Budget in March 1995. At the end of September 1994, Environmental Restoration had completed three of four performance measures by at least 180 percent. In the one area not fully completed, the program completed 62 of 80 assessments, or 78 percent. More detailed information on the program's efforts to meet these measures can be found in the following table. 
Environmental Management's Office of Financial Management, which is coordinating the development of these plans, issued guidelines in July 1994 so that the 1995 Performance Plan, issued in October 1994, includes more specific measures for each program. These measures will ensure productivity and efficiency improvements, customer satisfaction measures, safery and health goals, improved performance are incorporated into every Environmental Management activity.

\begin{tabular}{l|l}
\hline EM Overall & Status \\
\hline
\end{tabular}

\section{Compliance \& Program Integration}

Increase stakeholder involvement by 25 percent

Ensure that 22 sites are operational on the Automated Transportation Management System

\section{Waste Management}

Complete 14 of the 24 activities required by the Secretary's safery initiative for accelerating the resolution of tank safery issues at Hanford.

Achieve a 2-4 million gallon volume reduction of leaking tanks at . Hanford.

Process 20.2 million gallons of liquid waste

\section{Environmental Restoration}

Complete 80 assessments.

Complete 29 interim actions

Complete 12 remedial actions

\section{Technology Development}

100 percent completed

Completed

Completed

$90 \%$ or more completed

Completed 23

Achieved 2.4 million gallon reduction

Actual was 19.2

\section{$90 \%$ or more completed}

62 Assessments were complered (78\%)

119 were completed

31 were completed

100 percent completed

In the 5 focus areas, 64 improved technologies or systems were demonstrated in 1994.

11 improved technologies or systems were transferred to the private sector in 1994.

$\$ 25$ million realized in cost savings through implementation of new or improved techinologies.

\section{0 percent completed}

Surveillance and Maintenance costs at Idaho and Oak Ridge were reduced by $\$ 2.7$ million and $\$ 60,000$, respectively.<smiles>[131IH]</smiles>

Idaho conducted 25 surveys related to 7 completed plant projects to determine user satisfaction.

Performance 5. 199+ Performance Measures Status. 